ALEXANDRE PERRI DE MORAES

\title{
QUALIDADE DO AR INTERNO COM ÊNFASE NA CONCENTRAÇÃO DE AERODISPERSÓIDES NOS EDIFÍCIOS
}

Dissertação apresentada à Escola

Politécnica da Universidade de

São Paulo para a obtenção de

Título de Mestre em Engenharia.

São Paulo

2006 
ALEXANDRE PERRI DE MORAES

\section{QUALIDADE DO AR INTERNO COM ÊNFASE NA CONCENTRAÇÃO DE AERODISPERSÓIDES NOS EDIFÍCIOS}

Dissertação apresentada à Escola

Politécnica da Universidade de

São Paulo para a obtenção de

Título de Mestre em Engenharia.

Área de Concentração:

Engenharia de Construção Civil

Orientador:

Prof. Livre-Docente

Racine Tadeu Araújo Prado

São Paulo 
Este exemplar foi revisado e alterado em relação à versão original, sob responsabilidade única do autor e com a anuência de seu orientador.

São Paulo, de julho de 2006.

Assinatura do autor

Assinatura do orientador

FICHA CATALOGRÁFICA

Moraes, Alexandre Perri de

Qualidade do ar interno com ênfase na concentração de aerodispersóides nos edifícios / A.P. de Moraes. -- ed.rev. -São Paulo, 2006.

$159 \mathrm{p}$.

Dissertação (Mestrado) - Escola Politécnica da Universidade de São Paulo. Departamento de Engenharia de Construção Civil.

1.Qualidade do ar interno 2.Aerodispersóides 3.Materiais particulados 4.Fontes de emissão 5.Poluição do ar 6.Síndrome dos edifícios doentes I.Universidade de São Paulo. Escola Politécnica. Departamento de Engenharia de Construção Civil II.t. 
Aos meus pais

Maria Teresa e Marivaldo 


\section{AGRADECIMENTOS}

Ao Conselho Nacional de Desenvolvimento Científico e Tecnológico, pela concessão da bolsa de mestrado e pelo apoio financeiro para a realização desta pesquisa.

Ao Programa de Uso Racional da Água, pela contribuição prestada aos estudos.

Ao meu orientador $\operatorname{Prof}^{\circ}$ Dr. Racine Tadeu Araújo Prado, pela valiosa orientação e direcionamento deste trabalho. Muito Obrigado!

Aos meus pais, pela oportunidade que me deram de até aqui poder chegar, bem como a toda a minha família.

Às empresas, aos proprietários das residências e apartamentos, por terem permitido a realização das amostras.

À geóloga Maria Cristina de Moraes, à química Maria Ângela de Moraes Cordeiro, ao doutor César Magnus Pusch e à doutora Marly Cravo Pusch pelas correções dos textos da qualificação e da dissertação.

À arquiteta Cibele Iervolino, pelo amor e pela dedicação para elaborar as figuras em planta e em perspectiva.

Aos professores, pós-graduandos, funcionários e a secretaria da EPUSP/PCC. Aos colegas do curso de Mestrado de Engenharia de Construção Civil e Urbana.

Ao Grupo do Laboratório de Sistemas Prediais, pela amizade e convívio.

A todos aqueles que de uma maneira ou de outra colaboraram para a realização deste trabalho. 
"Não se pode ensinar alguma coisa a alguém, pode-se apenas auxiliar a descobrir por si mesmo." (Galileu Galilei) 


\section{RESUMO}

No presente trabalho, é avaliada a qualidade do ar interno com ênfase na concentração de aerodispersóides presentes em edifícios comerciais e residenciais com sistema de ventilação natural ou condicionamento de ar. De fato, algumas doenças de origem ocupacional são causadas pela inalação de aerodispersóides nocivos à saúde. $\mathrm{O}$ método utilizado para avaliar a qualidade do ar interno nos edifícios comerciais e residenciais consistiu primeiramente em caracterizar os medidores de aerodispersóides e em seguida passou-se para a análise das concentrações e das características ambientais. A pesquisa mediu a concentração de aerodispersóides em edifícios com sistemas de ventilação diferentes ( $1^{\underline{a}}$ fase), e identificou as principais fontes de emissão de aerodispersóides em um apartamento residencial ( $2^{\underline{a}}$ fase). Observou-se que as concentrações obtidas na pesquisa estão acima dos valores recomendados na $\operatorname{RE~}^{\circ} 9$ (ANVISA, 2003) e por Morawska et al. (1999) que atribuem valores de $80 \mu \mathrm{g} / \mathrm{m}^{3}$ e 7.400 part./ $\mathrm{cm}^{3}$, para concentrações médias em massa e em número, respectivamente. Com base nas observações acima, chegou à conclusão que as concentrações médias em massa e em número de aerodispersóides, durante as atividades domésticas (cozimento, reforma, limpeza, entre outras), foram várias vezes maiores do que as concentrações obtidas em ambientes com atividades profissionais ou com menor ocupação durante o dia. 


\begin{abstract}
This paper is the result of quality evaluation of indoor air quality with emphasis on the concentration of aerodispersoid in commercial and residential buildings with natural ventilation or air conditioning systems. In fact, some of the occupational diseases are caused by the inhalation of aerodispersoids hazardous to health. The method applied to evaluate the indoor air quality in commercial and residential buildings consisted firstly of characterizing the aerodispersoid measuring devices and subsequently analyzing the concentration levels and environmental characteristics. This research measured the concentration of aerodispersoids in buildings equipped with a variety of ventilation systems (phase1) and next it identified the main emission sources in a residential apartment (phase 2). It was observed that the concentration levels measured were above the specifications recommended by RE $n^{\circ}$ 9 (ANVISA, 2003) and by Morawska et al. (1999) which attribute values of 80 $\mu \mathrm{g} / \mathrm{m}^{3}$ and 7.400 part. $/ \mathrm{cm}^{3}$, for average concentration in mass and number respectively. Based on the above information it was concluded that the average concentration levels of aerodispersoids in mass and number in home related activities (cooking, restoration, cleaning, etc) were many times higher than the concentration levels found in business environments or in environments with less occupation during the day.
\end{abstract}




\section{LISTA DE FIGURAS}

Figura 1 - Exemplar de um “edifício inteligente” do Século XXI. Fonte: Bartz, 2004.

Figura 2 - Fontes internas e externas de poluente do ar em uma residência.

Figura 3 - Impurezas em suspensão no ar, partículas típicas, método de controle, tipo de radiação nesse comprimento de onda. Fonte: Mesquita et al., 1988.

Figura 4 -Sistema de ar-condicionado com equipamento do tipo self-contained, com condensador a ar acoplado.

Figura 5 - Configuração da máxima convergência à jusante do plano da vena-contracta, para um fluxo de ar entrando no duto. Fonte: Mesquita et al., 1988.

Figura 6 - Porcentagens de ocorrência dos sintomas em usuários de edifícios doentes, em função do ar-condicionado e da ventilação natural. Fonte: Wong e Huang., 2004

Figura 7 - Concentração em massa para os 17 elementos inorgânicos presentes nos materiais particulados $\left(\mathrm{MP}_{2,5}\right)$, em ambientes interno e externo. Fonte: Chao e Wong. (2002)

Figura 8 - Concentração em massa para os 17 elementos inorgânicos presentes nos aerodispersóides $\left(\mathrm{MP}_{10}\right)$, em ambientes interno e externo. Fonte: Chao e Wong. (2002)

Figura 9 - Classificação dos aerodispersóides quanto ao tamanho e ao local de penetração no pulmão. Fonte: Santos, 2005

Figura 10 - Detalhe do funcionamento do pulmão para partículas maiores que $1,0 \mu \mathrm{m}$. Fonte: TSI, 2003.

Figura 11 - Detalhe do funcionamento do pulmão para partículas menores que $1,0 \mu \mathrm{m}$. Fonte: TSI, 2003.

Figura 12 - Comparação entre o método de espalhamento de luz (Dust-Trak) e de amostrador de grande volume (Hi-Vol Sampler). Fonte: Guo et al. (2004)

Figura 13 - Número de ultrapassagens do padrão e do nível de atenção para aerodispersóides menores que $10 \mu \mathrm{m}$, por mês (1997 à 2004) na RMSP. Fonte: CETESB, 2004

Figura 14 - Croqui da cozinha, com o posicionamento das portas, das janelas, da mobília e dos equipamentos.

Figura 15 - Croqui da sala de estar, sala de jantar, hall social e hall de entrada, com o posicionamento dos equipamentos, das janelas, das portas e da mobília.

Figura 16 - Croqui da área de serviço, com o posicionamento dos equipamentos, das janelas, das portas e da mobília.

Figura 17 - Croqui do dormitório, com o posicionamento dos equipamentos, das janelas, das portas e da mobília. 
Figura 18 - Croqui do banheiro, com o posicionamento dos equipamentos, das janelas, das portas e da mobília.

Figura 19 - Concentração em massa de aerodispersóides para os ambientes internos localizados na RMSP.

Figura 20 - Porcentagens do tempo de medição da concentração em massa de aerodispersóides acima de $80 \mu \mathrm{g} / \mathrm{m}^{3}$, para os ambientes internos localizados na RMSP.

Figura 21 - Porcentagens do tempo médio de permanência das pessoas nos ambientes internos e externos, durante vinte e quatro horas. Fonte: Adgate et al., 2002.

Figura 22 - Porcentagens acumuladas do tempo que a concentração média em massa de aerodispersóides ficou entre 0 e $80 \mu \mathrm{g} / \mathrm{m}^{3}, 81$ e $100 \mu \mathrm{g} / \mathrm{m}^{3}, 101$ e $120 \mu \mathrm{g} / \mathrm{m}^{3}$, e maior que $121 \mu \mathrm{g} / \mathrm{m}^{3}$.

Figura 23 - Concentração em número de aerodispersóides para os ambientes internos localizados na RMSP

Figura 24 - Porcentagens do tempo de medição da concentração em número de aerodispersóides acima de 7.400 part./ $\mathrm{cm}^{3}$, para os ambientes internos localizados na RMSP

Figura 25 - Porcentagens acumuladas do tempo que a concentração em número de aerodispersóides ficou entre 0 e $7,4 \times 10^{3}$ part. $/ \mathrm{cm}^{3}$, entre 7,5 e $10 \times 10^{3}$ part. $/ \mathrm{cm}^{3}$, entre 10,1 e $12 \times 10^{3}$ part. $/ \mathrm{cm}^{3}$, e maior que $12,1 \times 10^{3}$ part./cm.

Figura 26 - Distribuição da concentração de aerodispersóide, da temperatura e da umidade relativa em vinte e quatro horas para a cozinha do apartamento $(12 / 01 / 06)$.

Figura 27 - Distribuição da concentração de aerodispersóide, da temperatura e da umidade relativa em vinte e quatro horas para a sala de estar do apartamento (13/01/06).

Figura 28 - Distribuição da concentração de aerodispersóide, da temperatura e da umidade relativa em vinte e quatro horas para a área de serviço do apartamento $(14 / 01 / 06)$

Figura 29 - Distribuição da concentração de aerodispersóide, da temperatura e da umidade relativa em vinte e quatro horas para o dormitório do apartamento (15/01/06).

Figura 30 - Distribuição da concentração de aerodispersóide, da temperatura e da umidade relativa em vinte e quatro horas para o banheiro do apartamento (16/01/06).

Figura 31 - Distribuição da concentração de aerodispersóide, da temperatura e da umidade relativa em vinte e quatro horas para a sala de estar do apartamento (18/01/06).

Figura 32 - Porcentagens do tempo de medição em que a concentração média em massa de aerodispersóides ficou acima de $80 \mu \mathrm{g} / \mathrm{m}^{3}$, para as atividades realizadas no apartamento

Figura 33 - Tempo de permanência das pessoas nos ambientes do apartamento. 
Figura 34 - Porcentagens acumuladas do tempo que a concentração média em massa de aerodispersóides ficou entre 0 e $80 \mu \mathrm{g} / \mathrm{m}^{3}, 81$ e $600 \mu \mathrm{g} / \mathrm{m}^{3}, 601$ e $1.120 \mu \mathrm{g} / \mathrm{m}^{3}$, e maior que $1.121 \mu \mathrm{g} / \mathrm{m}^{3}$

Figura 35 - Porcentagens acumuladas do tempo que a concentração média em número de aerodispersóides ficou entre 0 e $7,4 \times 10^{3}$ part./ $\mathrm{cm}^{3}$, entre 7,5 e $60 \times 10^{3} \mathrm{part} . / \mathrm{cm}^{3}$, entre 60,1 e $112 \times 10^{3}$ part. $/ \mathrm{cm}^{3}$, e maior que $112,1 \times 10^{3}$ part. $/ \mathrm{cm}^{3}$.

Figura 36 - Correlação entre a concentração interna e externa em massa de aerodispersóides no apartamento.

Figura 37 - Correlação entre a concentração interna em número de aerodispersóides e a umidade relativa interna no apartamento.

Figura 38 - Correlação entre a concentração interna em número de aerodispersóides e a temperatura interna no apartamento.

Figura 39 - Distribuições da concentração em massa $\left(\mathbf{P M}_{2,5}\right)$ e em número (SMPS e APS) de aerodispersóides para uma residência com ventilação mínima; antes, durante e após teste de cozimento. Fonte: He et al. (2004).

Figura 40 - Distribuições da concentração em massa $\left(\mathbf{P M}_{2,5}\right)$ e em número (SMPS e APS) de aerodispersóides para uma residência com ventilação normal; antes, durante e após teste de cozimento. Fonte: He et al. (2004).

Figura 41 - Diagramas da velocidade do ar em um ambiente com ventilação cruzada, à esquerda, e com ventilação não cruzada, à direita. Fonte: Zhao et al. (2004)...... 123

Figura 42 - Deposição de partículas (1), remoção de partículas (2) e ressuspensão de partículas (3), para ventilação cruzada ou não cruzada. Fonte: Zhao et al. (2004)

Figura 43 - Correlação entre a concentração em massa e as condições do tráfego. Fonte: Chao e Wong. (2002).

Figura 44 - Correlação entre a concentração em massa e a presença de fumaça de cigarro com relação aos elementos químicos em residências. Fonte: $\mathrm{Na}$ el at. (2004). 
LISTA DE TABELAS

Tabela 1 - Poluentes do ar de interiores e as respectivas fontes de emissão interna e externa. Fonte: EPA, 2002

Tabela 2 - Meios de infiltração de ar e respectivas causas para esse fato em ambientes internos e externos. Fonte: EPA, 2002.

Tabela 3 - Tamanho ou diâmetro aerodinâmico dos principais aerodispersóides. Fonte: Mesquita et al., 1988.

Tabela 4 - Coeficientes de dose-resposta para os efeitos devido à concentração de material particulado $\left(\mathrm{MP}_{10}\right.$ e $\left.\mathrm{MP}_{2,5}\right)$. Fonte: Tse et al, 2004.

Tabela 5 - Valores de referência para concentração em massa de $\mathbf{P M}_{10}$. Fontes: Tse et al (2004) e CETESB (2004)

Tabela 6 - Características e localização dos edifícios analisados. 80

Tabela 7 - Valores médios de temperatura, umidade relativa, concentração em massa, referência de concentração e condições do tempo (ensolarado e nublado), durante as medições de concentração em massa de aerodispersóides, para os ambientes internos localizados na RMSP

Tabela 8 - Principais características dos ambientes internos.

Tabela 9 - Valores médios de temperatura, umidade relativa, concentração em número, referência de concentração e condições do tempo (ensolarado e nublado), durante as medições de concentração em número de aerodispersóides, para os ambientes internos localizados na RMSP.

Tabela 10 - Valores médios das concentrações em massa para alguns pavimentos nos edifícios. Fonte: Chao e Wong (2002). 


\section{LISTA DE ABREVIATURAS E SIGLAS}

\begin{tabular}{|c|c|c|}
\hline ABNT & - & Associação Brasileira de Normas Técnicas \\
\hline ANVISA & - & Agência Nacional de Vigilância Sanitária \\
\hline APS & - & Aerodynamic Particle Sizer \\
\hline $\mathrm{Ar}$ & - & Argônio \\
\hline ASHRAE & - & $\begin{array}{l}\text { American Society of Heating, Refrigerating and Air } \\
\text { Conditioning Engineers }\end{array}$ \\
\hline BTU & - & British Thermal Unit \\
\hline $\mathrm{CPV}$ & - & Calibrador Padrão de Vazão \\
\hline CETESB & - & Companhia de Tecnologia de Saneamento Ambiental \\
\hline $\mathrm{CH}_{4}$ & - & Metano \\
\hline CIB & - & $\begin{array}{l}\text { International Council for Research and Innovation in Building } \\
\text { and Construction }\end{array}$ \\
\hline $\mathrm{CO}$ & - & Monóxido de Carbono \\
\hline $\mathrm{CO}_{2}$ & - & Dióxido de Carbono \\
\hline CONAMA & - & Conselho Nacional do Meio Ambiente \\
\hline $\mathrm{COV}$ & - & Compostos Orgânicos Voláteis \\
\hline DRE & - & Doenças Relacionadas aos Edifícios \\
\hline EPA & - & Environmental Protection Agency \\
\hline FEEMA & - & Fundação Estadual de Engenharia do Meio Ambiente \\
\hline $\mathrm{H}_{2}$ & - & Hidrogênio \\
\hline $\mathrm{He}$ & - & Hélio \\
\hline HVAC & - & Heating, Ventilating and Air-Conditioning \\
\hline HVS & - & High Volume Sampler \\
\hline INMET & - & Instituto Nacional de Meteorologia \\
\hline ISAIQ & - & International Society of Indoor Air Quality and Climate \\
\hline $\mathrm{Kr}$ & - & Criptônio \\
\hline LVS & - & Low Volume Sampler \\
\hline MP & - & Material Particulado \\
\hline $\mathrm{MP}_{10}$ & - & Material Particulado Menor que $10 \mu \mathrm{m}$ \\
\hline $\mathrm{MP}_{2,5}$ & - & Material Particulado Menor que 2,5 $\mu \mathrm{m}$ \\
\hline $\mathrm{MP}_{1,0}$ & - & Material Particulado Menor que $1,0 \mu \mathrm{m}$ \\
\hline MVS & - & Médium Volume Sampler \\
\hline
\end{tabular}




\begin{tabular}{|c|c|c|}
\hline MS & - & Ministério da Saúde \\
\hline NBR & - & Norma Brasileira \\
\hline $\mathrm{N}_{2} \mathrm{O}$ & - & Óxido Nitroso \\
\hline $\mathrm{NO}_{\mathrm{x}}$ & - & Óxidos de Nitrogênio \\
\hline $\mathrm{Ne}$ & - & Neônio \\
\hline NT & - & Norma Técnica \\
\hline $\mathrm{O}_{3}$ & - & Ozônio \\
\hline OMS & - & Organização Mundial da Saúde \\
\hline OPAS & - & Organização Pan-Americana de Saúde \\
\hline PART & - & Partículas \\
\hline $\mathrm{Pb}$ & - & Chumbo \\
\hline $\mathrm{PbO}$ & - & Óxido de Chumbo \\
\hline PMOC & - & Plano de Manutenção, Operação e Controle \\
\hline PRORAD & - & Proteção Radiológica \\
\hline PVC & - & Polyvinyl Chloride or Vinyl \\
\hline QAI & - & Qualidade do Ar Interno \\
\hline RMSP & - & Região Metropolitana de São Paulo \\
\hline $\mathrm{Rn}$ & - & Radônio \\
\hline RSP & - & Respirable Suspended Particulates \\
\hline SED & - & Síndrome dos Edifícios Doentes \\
\hline SEMA & - & Secretaria Especial do Meio Ambiente \\
\hline SISNAMA & - & Sistema Nacional do Meio Ambiente \\
\hline SMPS & - & Scanning Mobility Particle Sizer \\
\hline $\mathrm{SO}_{2}$ & - & Dióxido de Enxofre \\
\hline $\mathrm{SO}_{\mathrm{x}}$ & - & Óxido de Enxofre \\
\hline TSI & - & Thermo-Systems Incorporated \\
\hline UFCs & - & Unidade de Formação de Colônias \\
\hline VAC & - & Ventilação e Ar-Condicionado \\
\hline $\mathrm{Xe}$ & - & Xenônio \\
\hline
\end{tabular}




\section{SUMÁRIO}

LISTA DE FIGURAS ................................................................................

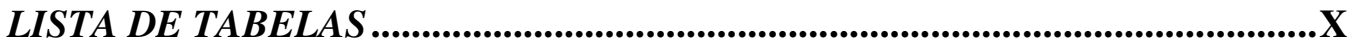

LISTA DE ABREVIATURAS E SIGLAS ....................................................

1. INTRODUÇÃO.........................................................................................17

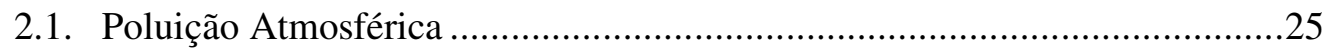

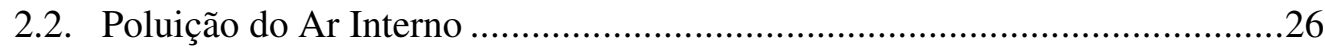

2.3. Fontes de Poluente do Ar Interno .........................................................29

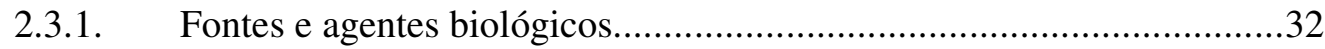

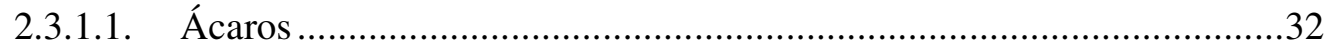

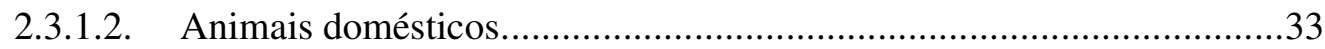

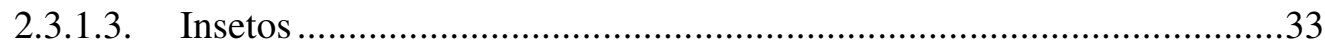

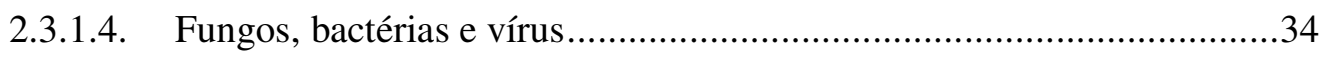

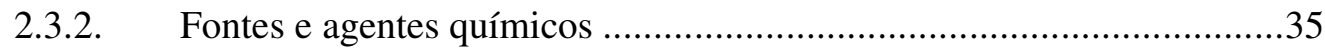

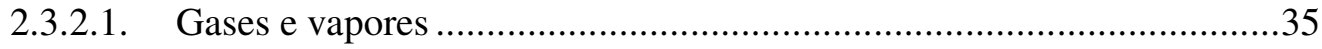

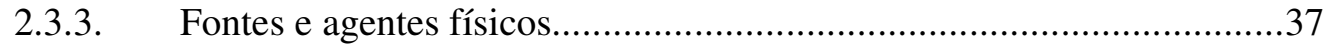

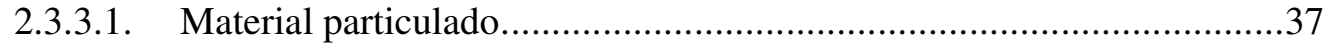

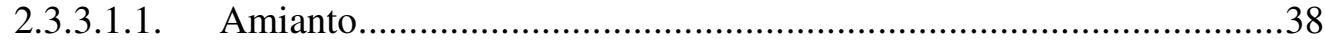

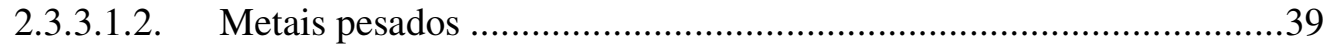

2.3.3.2. Campos eletromagnéticos ..................................................................39

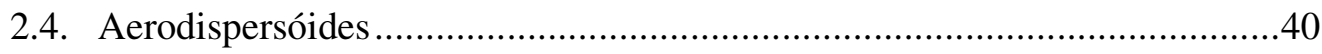

2.4.1. Definição e formação..............................................................40

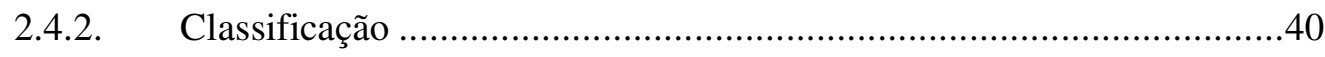

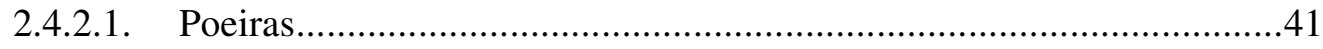

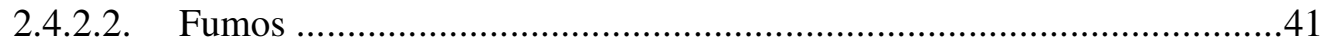

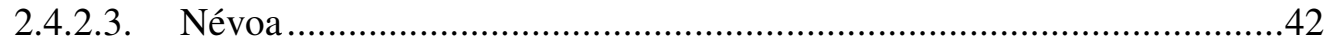

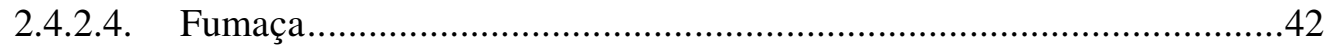

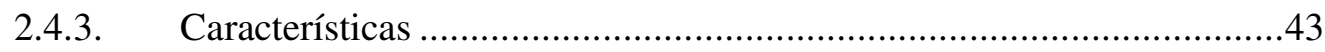


2.4.4. Propriedades dos aerodispersóides .................................................45

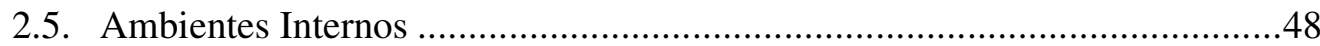

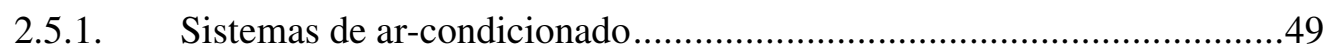

2.5.2. Sistemas de ventilação natural ......................................................53

2.5.3. Sistemas de ventilação diluidora .................................................54

2.5.4. Sistemas de ventilação local exaustora...............................................56

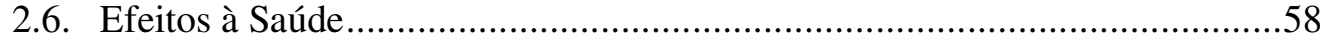

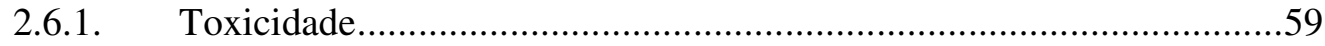

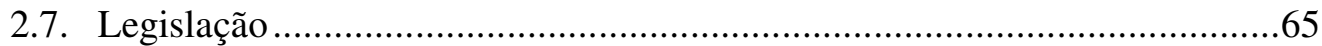

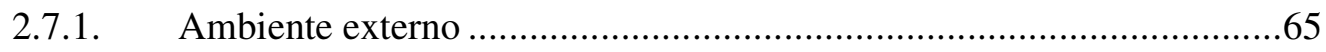

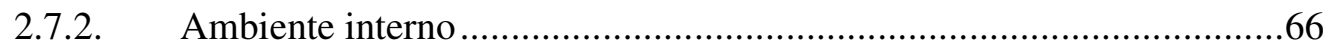

2.7.3. Padrões de concentração em massa.................................................69

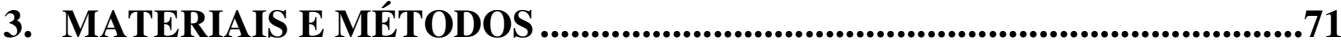

3.1. Revisão dos Métodos de Amostragem para Aerodispersóides.....................71

3.1.1. Métodos de amostragem da concentração em massa ...........................71

3.1.1.1. Método do amostrador de grande volume por gravimetria...................71

3.1.1.2. Método do amostrador por radiometria / Atenuação $\beta$.......................72

3.1.1.3. Método do amostrador por refletância / Black Smoke .........................72

3.1.1.4. Método do amostrador por nefelometria / espalhamento de luz ...........73

3.1.2. Métodos de amostragem da concentração em número de partículas .....74

3.1.2.1. Método de amostragem para contador ótico .....................................74

3.1.2.2. Método de amostragem para contador de núcleo de condensação..........74

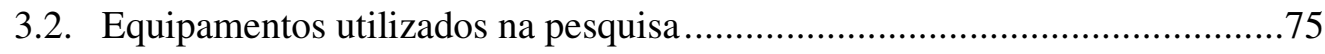

3.2.1. $\quad$ Monitor Dust-Trak para aerossóis (modelo 8520) …...........................75

3.2.2. Contador de partículas ultrafinas P-Trak (modelo 8525) …...................77

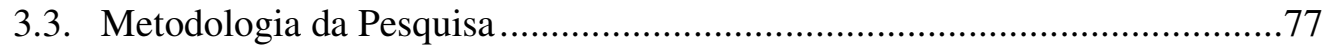

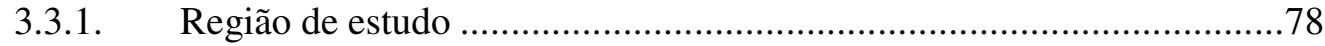

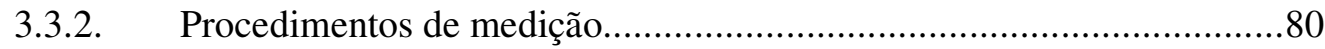

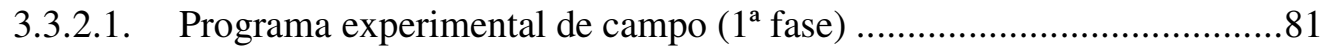

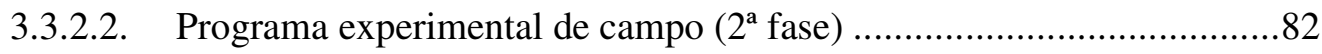

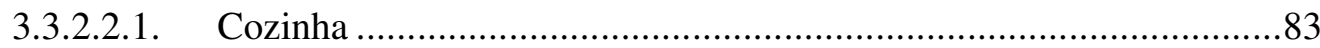




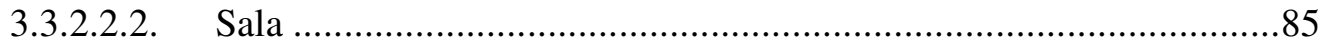

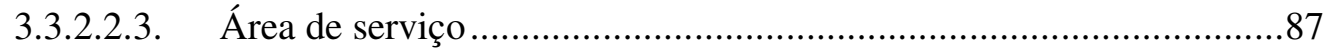

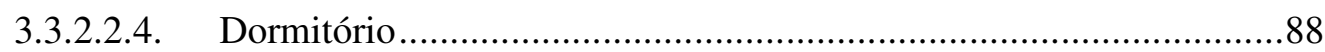

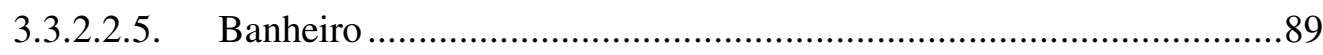

4. RESULTADOS E DISCUSSÃO ............................................................92

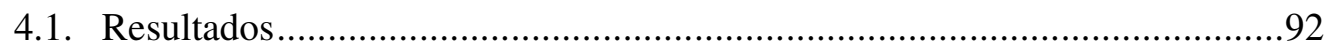

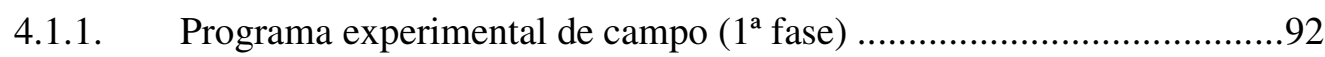

4.1.2. Programa experimental de campo ( $2^{\mathrm{a}}$ fase $)$................................... 103

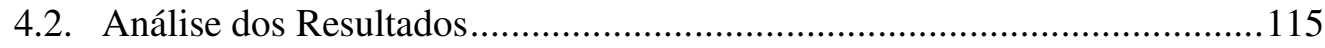

4.3. Discussão dos Resultados Quantitativos ...............................................120

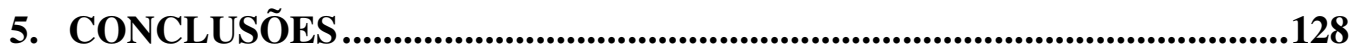

REFERÊNCIAS BIBLIOGRÁFICAS ............................................................130

ANEXO A - Resolução n ${ }^{0} 9$.....................................................................................139

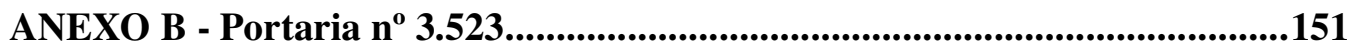

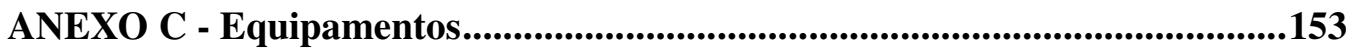




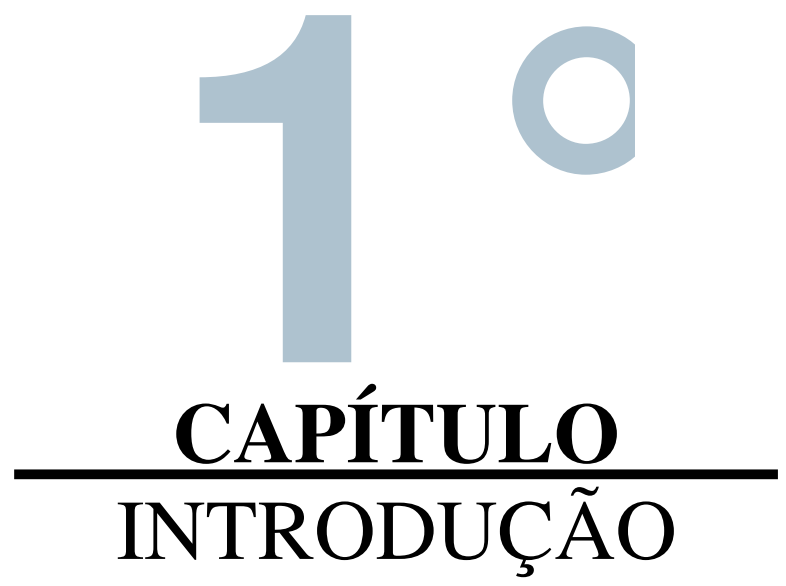




\section{INTRODUÇÃ̃}

A preocupação com a Qualidade do Ar Interno (QAI) tem levado ao desenvolvimento de pesquisas científicas em diversos países, inclusive o Brasil. Estas pesquisas envolvem diferentes áreas da ciência e tecnologia, as quais apresentaram várias publicações neste campo de pesquisas a partir de 1970, tendo como marco de referência para este tema a posição da American Society of Heating, Refrigerating and Air Conditioning Engineers (ASHRAE) que reconhece a existência do problema de Qualidade do Ar em Ambientes Internos e publica a norma ASHRAE Standard 62 de 1973, identificada originalmente por "Standard for Natural and Mechanical Ventilation”. Apesar das várias publicações neste campo de pesquisa, seu desenvolvimento está numa fase incipiente, considerando-se o potencial de pesquisa e as necessidades crescentes de respostas aos problemas relativos aos efeitos negativos do meio ambiente interno sobre seus ocupantes.

O ar constitui um elemento essencial à vida, devendo proporcionar bem estar e saúde aos seres humanos. Além do oxigênio, de acordo com Braga et al. (2005), a atmosfera terrestre contém outros gases, sendo principalmente o nitrogênio, o argônio e o gás carbônico. Em suspensão no ar, encontram-se substâncias sólidas, líquidas e gasosas, formadas por agentes físicos, químicos e biológicos, segundo Wolkoff et al. (1998). As fontes e os agentes de poluição do ar podem ser: ácaros, animais domésticos, insetos, fungos, bactérias, vírus, gases, materiais particulados, amianto, metais pesados e ondas eletromagnéticas (PRADO, 2003).

De acordo com a Organização Mundial da Saúde (OMS), a poluição de interiores é hoje reconhecida como uma das maiores ameaças à saúde pública. As doenças relacionadas com a qualidade do ar de interiores são classificadas pela OMS como Síndrome dos Edifícios Doentes (SED), tal sua importância e prevalência, decorrentes da urbanização e verticalização dos edifícios. O termo SED é usado para descrever situações nas quais $20 \%$ dos usuários de um determinado edifício experimentam efeitos adversos à saúde e ao conforto, que normalmente desaparecem quando as pessoas afetadas deixam o mesmo, como por exemplo: irritação das 
mucosas, efeitos neurotóxicos, sintomas respiratórios e cutâneos, e alteração dos sentidos (OMS, 1999). No entanto, a SED é uma questão multidisciplinar, exigindo estudos em diversas áreas da ciência e tecnologia, segundo José-Alonso et al. (1999).

Atualmente, sintomas relativos a SED não se restringem apenas a ambientes de trabalho. Segundo Junker et al. (2000), as pessoas permanecem 90\% de seu tempo em locais fechados, incluindo residências, escolas, hospitais, shoppings centers, supermercados, bancos, entre outros, os quais são ambientes não industriais. Nesses ambientes, ao contrário do que se imagina, também há uma elevada concentração de poluente, típicas desses espaços, podendo afetar a saúde dos usuários.

Os estudos da OMS, no início da década de 80 , descreveram a relação entre os sintomas característicos da SED e a ventilação mecânica, porém um estudo britânico foi mais longe e estabeleceu uma relação entre a existência dos sintomas e o sistema de ar condicionado. Mas, foi a partir dos anos 90 que a SED tornou-se um conceito comum na literatura científica, por meio de publicações em âmbito internacional, que somando às prospecções anteriores, contribuíram para aperfeiçoar ainda mais essa questão.

Nesse sentido, a International Society of Indoor Air Quality and Climate e a International Council for Research and Innovation in Building and Construction (ISIAQ-CIB), em 2003, publicaram os critérios de desempenho para ambientes internos às edificações, correlacionando valores normativos às metas de projeto, execução e manutenção dos mesmos. Segundo estas instituições, a qualidade do ar interno pode diminuir os problemas de saúde e o desconforto dos usuários, por meio dos métodos construtivos, da escolha dos materiais de construção e da gestão de manutenção preventiva dos ambientes internos aos edifícios.

Este panorama tem levado a uma gradual mudança de paradigma: o modelo baseado nas causas e efeitos do ponto de vista das ciências da saúde tem sido substituído pelo modelo de organismos representativos, ou seja, modelo por amostragem ou por 
estudos de caso, mais coerente com as idéias de desempenho da edificação, garantindo maior qualidade de vida aos usuários.

Neste cenário desenvolve-se a qualidade do ar interno, com toda uma cultura multidisciplinar acerca da questão preservação da composição do ar e diversos envolvidos - a sociedade, as entidades do meio técnico, profissionais, etc. - visando à diminuição dos problemas de saúde por meio de avaliações da poluição do ar. Para tanto, essa qualidade do ar interno prevê ações estruturadas de natureza técnica, administrativa, econômica e social/educacional, preocupando-se com o bem estar e a saúde dos usuários desde o nível macro (gerenciamento de poluição externa do ar gerada por indústrias e veículos) até o nível micro (sistemas prediais).

Dentre os benefícios da boa qualidade do ar interno, destacam-se:

- Proteção da saúde do usuário - reduzindo a concentração de poluente nocivo abaixo de um certo limite de tolerância.

- Segurança do usuário - reduzindo a concentração de poluente explosivo ou inflamável abaixo dos limites de explosividade e inflamabilidade.

- Conforto e eficiência do usuário - pela manutenção de temperatura e da umidade do ar do ambiente.

- Proteção de materiais ou equipamentos - mantendo condições atmosféricas adequadas (impostas por motivos tecnológicos).

Um exemplo de projeto estruturado ambientalmente é o edifício de escritórios da Swiss Re, localizado no centro financeiro de Londres. Os estudos para o desenvolvimento do projeto consideraram a sustentabilidade do empreendimento, tanto com relação aos custos dos sistemas prediais, quanto ao bem estar e saúde dos usuários (PAIVA, 2004). As principais condicionantes do projeto são:

- Sistema de fachada dupla ventilada, com pontos de entrada de ar na fachada externa, espaço para troca de ar dentro de câmaras e persianas motorizadas na fachada interna. 
- Fachada externa composta por aproximadamente 5.500 painéis de vidros planos, que se assemelha a uma lente prismática com micro-perfurações, permitindo que o edifício "respire". O ar entra através de orifícios na envoltória externa, circula pelos ambientes internos por insuflamento pelo piso e sai, em movimento ascendente, pelo poço de luz.

- Sistema de ventilação natural, semelhante ao do edifício do Commerzbank, em Frankfurt, através de poços de luz distribuídos do topo à base do edifício, permitindo a troca de ar nos ambientes internos.

- Sistema de automação nas janelas da fachada, que controla a abertura por computadores conectados as estações de controle de temperatura, precipitações pluviométricas, intensidade do sol e velocidade do vento. Quando as condições atmosféricas externas não são hostis, o sistema abre gradualmente as janelas dos poços de luz, permitindo que o ar externo (ventilação natural) percorra os ambientes internos. As persianas podem ser controladas diretamente pelos usuários, a partir de seus postos de trabalho, quando o sistema está desativado.

Dentre os níveis de atuação da qualidade do ar interno percebe-se a importância da abordagem no nível mais próximo aos usuários finais, aos sistemas prediais, uma vez que neste nível são grandes as possibilidades de intervenção e o potencial de resultados. Os programas contra a poluição do ar interno, ou mesmo ações isoladas, considerando sob o enfoque dos sistemas prediais, têm sido intensamente noticiada nos últimos anos, devido aos crescentes problemas de doenças ocasionadas aos usuários.

A qualidade do ar interno é a interação de inúmeros fatores, entre eles, os poluentes químicos, físicas e biológicas, assim como as características dos sistemas prediais e as atividades dos usuários nos ambientes, de acordo com Jones (1998). Para o autor, a principal fonte de aerodispersóides nos ambientes internos é a fumaça de cigarro. Contudo, estas fontes podem ser minimizadas quando os sistemas prediais forem utilizados corretamente. 
O domínio das fontes de poluição do ar nesta conjuntura adquire importância fundamental, pois através de sua análise são verificadas as concentrações, em um primeiro instante, e o benefício à saúde dos usuários nas etapas subseqüentes. A importância de medir a concentração de poluente, como elemento que permite a avaliação da qualidade do ar em ambientes internos reside no fato de que a cada intervenção realizada é possível verificar os resultados alcançados em termos absolutos (concentração) e relativos (porcentagem) e criar indicadores de conforto apropriados como, por exemplo, taxa de renovação de ar, índices de eficiência de filtragem e classes de materiais poluentes. Com estes dados pode-se inferir o sucesso das ações adotadas.

Mesmo após as ações realizadas, faz-se necessário o acompanhamento permanente da poluição do ar interno, constituindo o domínio deste dado em um instrumento para gestão de operação e de manutenção dos sistemas envolvidos.

A concentração total de poluente em um ambiente interno depende do volume de ar contido nesse espaço, da taxa de produção de poluente, da taxa de remoção de poluente, da taxa de troca de ar externo e da concentração de poluente externo, (MARONI et al.,1995 apud JONES, 1999).

Por estas razões percebe-se a necessidade de uma abordagem sistêmica para a questão, indicando as condições ideais para que se estabeleça esta correspondência (entre o ambiente e o usuário) e seja possível a utilização dos dados de concentração de poluente como instrumento de gestão.

No presente trabalho tem-se por objetivo avaliar a qualidade do ar interno, com ênfase na concentração de aerodispersóides em massa e em número, em diversos edifícios localizados na Região Metropolitana de São Paulo. Propõe-se, também, que o trabalho constitua uma base de informações e sirva de subsídio para decisões em casos semelhantes de controle de aerodispersóides em ambientes internos, maximizando seus benefícios. 
Os aspectos dos sistemas de ventilação e de climatização e suas relações com a proposta de medição foram considerados sob uma visão sistêmica, tendo a avaliação de aerodispersóides importância fundamental por suas propriedades intrínsecas entre as fontes de poluição do ar e as doenças ocasionadas aos usuários.

Introduzida neste contexto, a avaliação de aerodispersóides em ambientes internos localizados na Região Metropolitana de São Paulo (RMSP) é apresentada com suas diversas implicações.

Surge, então, a proposta de implantação de uma medição de aerodispersóides como instrumento de controle da qualidade do ar interno nos sistemas prediais. Para efeito de organização do texto, o trabalho foi estruturado segundo os seguintes capítulos:

- Capítulo 1 - Apresentam-se as justificativas e os objetivos da pesquisa.

- Capítulo 2 - Apresenta-se a revisão bibliográfica com os principais aspectos sobre os aerodispersóides e seu potencial de risco a saúde humana.

- Capítulo 3 - Apresentam-se os principais métodos de medição dos aerodispersóides e a metodologia da pesquisa.

- Capítulo 4 - Apresentam-se os resultados quantitativos, as discussões dos resultados e das análises.

- Capítulo 5 - Apresentam-se as considerações finais quanto aos objetivos propostos e ao desenvolvimento de trabalhos futuros. 


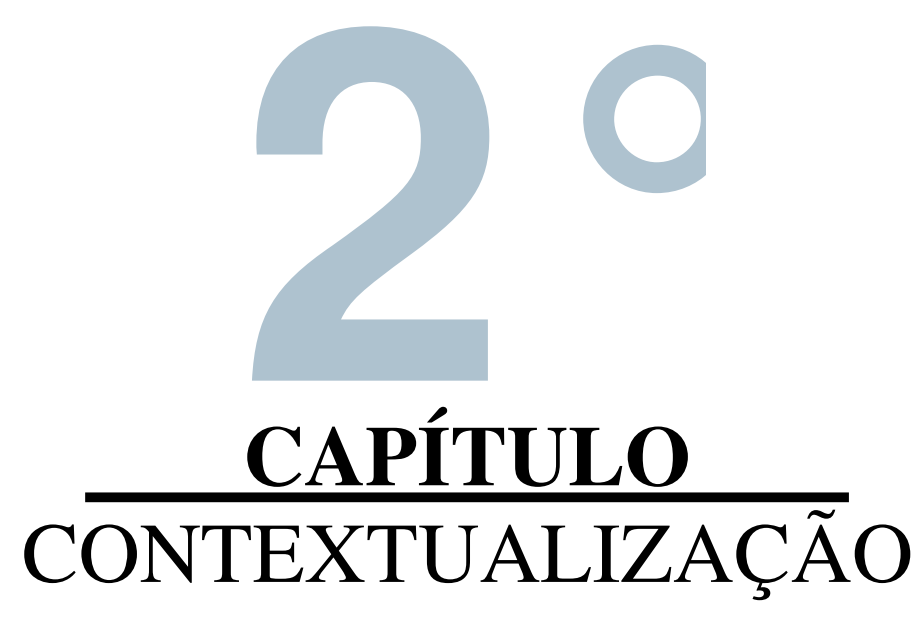




\section{CONTEXTUALIZAÇÃO}

O modo como a habitação foi se transformando ao longo dos tempos deve-se pela busca em torno da qualidade de vida. No século XIX, era comum ver habitações horizontais amplas e arejadas com poucos andares e pé direito de cinco a seis metros, espaços aberto para o exterior, janelas grandes que iluminavam e arejavam naturalmente os ambientes.

No século XX, as construções foram executadas em módulos menores e verticalizadas em múltiplos andares. A verticalização foi determinada pela concentração humana em áreas centrais das cidades, mais desenvolvidas e urbanizadas, porém mais perigosas. O desenvolvimento de materiais resistentes e leves, a aprimoramento do elevador e o aparecimento do fecho hídrico propiciaram a construção de modernos edifícios.

Com o tempo, houve a necessidade de incorporar tecnologias capazes de melhorar as condições ambientais internas. Os procedimentos incorporados foram planejamento, gerenciamento e manutenção, que atribuíram aos edifícios mais conforto, segurança e menores custos. Na Figura 1, apresenta-se um edifício com estas tecnologias incorporadas, sendo chamado de "edifício inteligente".

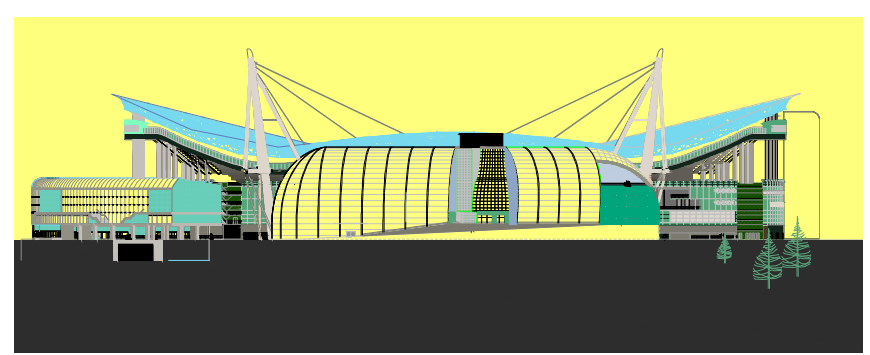

Figura 1 - Exemplar de um "edifício inteligente" do Século XXI. Fonte: Bartz, 2004.

Atualmente, a tendência em buscar novos mecanismos, para melhorar a qualidade de vida nos ambientes internos, traz à tona a questão da qualidade do ar. A preocupação com a poluição do ar interno tem aumentado nos últimos anos devido aos problemas 
de saúde, sendo atribuído esse fato às condições internas favoráveis a concentração de poluente no ar. As principais fontes de emissão são as atividades dos usuários, contaminação externa, degradação dos materiais, produtos químicos e reações fotoquímicas, de acordo com Allard (1989).

A preocupação com a poluição do ar interna ganhou repercussão em abril de 1998, após o falecimento do então Ministro das Comunicações, Sergio Motta, que ensejou o surgimento da Portaria 3523/GM, aos 28 de agosto de 1998. Esta Portaria é de grande importância para a conceituação da qualidade do ar interno, além de regulamentar parâmetros e disponibilizar um plano de manutenção, operação e controle para o sistema de climatização.

\subsection{Poluição Atmosférica}

A poluição atmosférica envolve algumas atividades e/ou fenômenos, que geram substâncias sólidas, líquidas ou gasosas, em níveis elevados o suficiente para prejudicar a saúde. Conforme a Resolução CONAMA n³, de 28/06/1990, considerase "poluente atmosférico qualquer forma de matéria ou energia com intensidade e em quantidade, concentração, tempo ou características em desacordo com os níveis estabelecidos, e que tornem ou possam tornar o ar impróprio, nocivo ou ofensivo à saúde, inconveniente ao bem-estar público, danoso aos materiais, à fauna e à flora ou prejudicial à segurança, ao uso e gozo da propriedade e às atividades normais da comunidade".

A variedade de substâncias que podem estar presentes na atmosfera é muito grande. No entanto, segundo a Companhia de Tecnologia de Saneamento Ambiental (CETESB), os poluentes podem ser classificados com relação a sua origem em: poluentes primários, sendo aqueles emitidos diretamente pelas fontes; e poluentes secundários, sendo aqueles formados na atmosfera por meio da reação química entre poluentes primários e/ou constituintes naturais na atmosfera. 
A poluição atmosférica é atribuída principalmente à atividade humana em vários aspectos, dentre os quais destacam-se o rápido crescimento populacional, industrial e econômico, os hábitos da população e o grau de controle em gerar poluentes.

A atmosfera é constituída principalmente de gases como o nitrogênio $(78,10 \%)$, o oxigênio (20,94\%), o argônio (0,93\%) e o dióxido de carbono (0,03\%). Apresentamse outros gases na composição da mesma, porém em pequenas concentrações, tais como: néon, hélio, metano, hidrogênio, xenônio e ozônio, entre outros $(0,003 \%)$ e vapor d'água (0,02\%, nas regiões áridas e 4\%, nas regiões úmidas), além de várias substâncias naturais e artificiais, como os clorofluorcarbonos (CFCs), partículas sólidas e líquidas em suspensão (aerodispersóides).

\subsection{Poluição do Ar Interno}

A poluição do ar interno, assim como os poluentes externos, vem contribuindo para agravar a saúde dos usuários nos ambientes internos. Segundo Prado (2003), os poluentes do ar interno são gerados principalmente por:

1. Fontes biológicas: ácaros, animais domésticos, insetos, fungos, bactérias e vírus.

2. Fontes químicas: gases e vapores.

3. Fontes físicas: material particulado (amianto e metais pesados) e campos eletromagnéticos.

As estimativas mais recentes da OMS mostram que a poluição em ambientes internos ocasiona aproximadamente 2,8 milhões de mortes anuais, o que a torna um dos maiores fatores de mortalidade do mundo, causando 5,5\% de todas as mortes. Tratase de um percentual extremamente alto, que sustenta a decisão do Banco Mundial de considerar a poluição em ambientes internos um dos quatro problemas ambientais mais cruciais do mundo. 
Os riscos da poluição do ar à saúde humana têm sido mais intensamente estudados desde longa data. Em 1987, o Escritório Regional da OMS para a Europa elaborou e publicou os "Critérios de Qualidade do Ar para a Europa". Em 1997, um Comitê de Especialistas da OMS reunido em Genebra, Suíça, ampliou o documento e estendeu a cobertura desses critérios a todo o mundo. O relatório resultou na publicação do "Critérios de Qualidade do Ar", editada em 1999.

O documento apresenta os níveis de poluição do ar que não implicam riscos significativos à saúde de um indivíduo exposto por um longo período ou por toda a vida. Os padrões de qualidade do ar são promulgados pelos governos e levam em consideração alguns fatores adicionais, como contaminação natural, níveis de exposição e condições ambientais (temperatura, umidade e altitude). A OMS tem como meta eliminar ou reduzir a exposição aos agentes poluidores, protegendo a saúde pública. Para isso, têm auxiliado os governos na formulação de seus próprios padrões, programas e políticas sobre qualidade do ar.

As atividades dos homens concentram-se 90\% do tempo em ambientes internos, conforme a Agência Nacional de Proteção Americana (EPA $\left.{ }^{1}\right)$. Porém, o consumo de energia tem diminuído por meio de projetos sem ventilação natural ou com pouca troca de ar externo, os quais diminuem a perda de carga térmica. Em contrapartida, os poluentes internos, gerados nestes ambientes, têm aumentado, agravando o desconforto dos usuários.

Uma das formas de melhorar a qualidade do ar interno é utilizar a ventilação para auxiliar a remoção dos poluentes do ar. A ventilação em um edifício potencializa-se por meio de renovação e de filtragem do ar, melhorado a produtividade e diminuindo o nível de doenças. Em ambientes condicionados as taxas mínimas de ventilação necessárias para garantir a qualidade do ar interno são fixadas através de Normas Técnicas, a exemplo da Norma ASHRAE Standard 62. No Brasil pode-se considerar que a preocupação com a qualidade do ar em ambientes com ar condicionado

\footnotetext{
${ }^{1}$ U.S. Environmental Protection Agency
} 
iniciou-se em 28 de agosto de 1998 com a aprovação da Portaria $n^{\circ} 3.523$ pelo Ministério da Saúde (MS).

O nível de poluição do ar ambiente pode ser melhorado por meio de valores máximos de emissão de poluente, a fim de não causar ou agravar doenças aos usuários e assegurar o melhor desempenho às atividades ocupacionais (KOSONEN E TAN, 2004). A emissão do poluente não depende somente dos materiais de construção civil, da poluição atmosférica, das atividades internas, do volume de ar contaminado e da taxa de ressuspensão dos poluentes, mas principalmente das condições de temperatura e de umidade relativa, segundo Virta et al. (2005).

A seguir, na Figura 2, apresentam-se as principais fontes internas e externas de poluente do ar em uma residência.

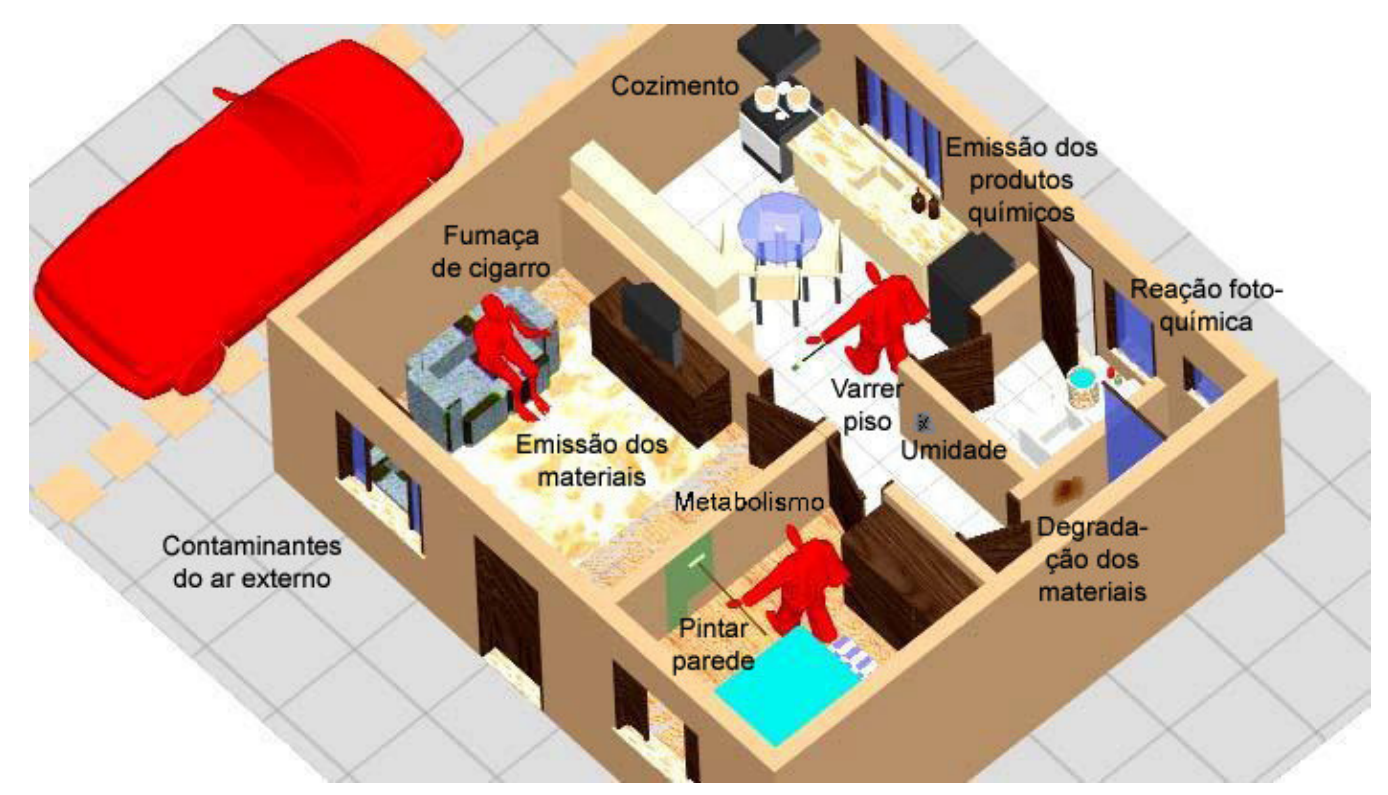

Figura 2 - Fontes internas e externas de poluente do ar em uma residência. 


\subsection{Fontes de Poluente do Ar Interno}

Os poluentes do ar são gerados por processos naturais ou antropogênicos, em forma de matéria ou energia contaminante. As fontes naturais do ar interno podem ser a ressuspensão de poeira do piso pelo vento, a formação de gás em tubulação de esgoto, a liberação de excrementos de pássaros, baratas ou roedores, os pólens de plantas, deterioração dos materiais constituintes, entre outros. As fontes antropogênicas do ar interno podem ser as diversas atividades de cozimento, limpeza, reforma e combustão do cigarro, a formação de gases dos produtos voláteis, as reações biológicas do metabolismo humano, entre outros.

Os problemas de saúde associados com os ambientes internos, de acordo com Wong (2004), são devidos às fontes de poluição, podendo ser estas classificadas em químicas, físicas e biológicas. As fontes de poluição podem apresentar em alguns casos baixos níveis de emissão, porém podendo ser nocivas e perigosas.

Em suas pesquisas, Niu e Burnett (2001) afirmam que há poucos materiais de construção que estão livres de emissão de poluente, como os vidros e os metais. As emissões dos materiais de construção civil variam em função do tempo, sendo esta variação chamada de taxa de declínio. As tintas e os adesivos têm uma alta taxa de declínio, enquanto a emissão de madeiras (aldeído) e de concreto (radônio) podem permanecer durante alguns anos.

O controle de uma fonte de poluição é garantido observando a concentração máxima admissível e calculando a quantidade de ar externo necessário para sua diluição. Esta diluição exige grandes taxas de ar externo e, posteriormente, maiores gastos com energia. É correto e, em geral, mais econômico evitar a dispersão dos poluentes químicos, físicos e biológicos, do que adotar soluções corretivas.

Tanto as fontes internas, quanto as fontes externas contribuem para afetar a concentração e composição dos poluentes nas edificações (HE et al., 2004). Segundo os autores citados, há mais informações sobre as características das fontes externas 
do que das fontes internas, embora a quantificação da emissão das fontes internas seja muito importante para avaliar a exposição total dos poluentes que realmente afetam a saúde dos usuários.

Observa-se que as pessoas e as atividades ocupacionais geram ressuspensão de partículas maiores que $2,5 \mu \mathrm{m}$. No entanto, a elevação de partículas menores que 2,5 $\mu \mathrm{m}$ ocorrem devido principalmente à presença de cozimento e de fumaça de cigarro (JONES et al. ,2000).

As principais fontes de emissão dos ambientes externos em áreas urbanas são os veículos e as indústrias, segundo Matson (2005) e Morawska et al. (1999). A maior contribuição de partículas destas fontes são as partículas ultrafinas, ou seja, partículas menores que $0,1 \mu \mathrm{m}$, pois neste caso há pouca partícula (menos de 10\%) com diâmetro aerodinâmico maior que $0,1 \mu \mathrm{m}$.

Segundo Assunção et al. (1979), o planejamento urbano pode ser um dos meios de controle da poluição do ar atmosférico. Alguns dos fatores a serem considerados neste planejamento são a direção de ventos, as características topográficas e climáticas da região, a posição da área industrial em relação às áreas residenciais e de uso institucional (especialmente hospitais e escolas), os recursos hídricos, o sistema de transporte e comunicação, a disponibilidade de infra-estrutura de saneamento básico, etc. 
Na tabela 1, apresenta-se a relação entre as principais fontes de emissão e os tipos de poluente do ar, as quais podem ser internos e/ou externos.

Tabela 1 - Poluentes do ar de interiores e as respectivas fontes de emissão interna e externa. Fonte: EPA, 2002.

\begin{tabular}{|c|c|}
\hline Poluentes do ar & Fontes de Emissão \\
\hline Fuligem de fumaça de cigarro & Acender ou fumar cigarros \\
\hline Contaminação pela combustão & $\begin{array}{l}\text { Fornalhas, geradores, aquecedores a gás ou } \\
\text { querosene, produtos derivados do tabaco, ar } \\
\text { externo, veículos }\end{array}$ \\
\hline Contaminação biológica & $\begin{array}{l}\text { Materiais molhados ou úmidos, ar- } \\
\text { condicionado, umidificadores, manta de } \\
\text { isolação de dutos, respiros da tubulação de } \\
\text { esgotos, excremento de pássaros, de baratas ou } \\
\text { de roedores, odores do corpo }\end{array}$ \\
\hline Compostos Orgânicos Voláteis (COV) & $\begin{array}{l}\text { Pinturas, vernizes, solventes, pesticidas, } \\
\text { adesivos, ceras, produtos de limpeza, } \\
\text { lubrificantes, purificadores de ar, combustíveis, } \\
\text { plásticos, copiadoras, impressoras, produtos } \\
\text { derivados do tabaco, perfumes }\end{array}$ \\
\hline Aldeídos & $\begin{array}{l}\text { Chapas e compensados de madeira, } \\
\text { aglomerados, carpetes de madeira, móveis, } \\
\text { forros }\end{array}$ \\
\hline Gases & $\begin{array}{l}\text { Solo e rochas (radônio), ventilação da } \\
\text { tubulação de esgoto, ralos com fecho hídrico } \\
\text { seco, reservatórios subterrâneos com } \\
\text { vazamento }\end{array}$ \\
\hline Pesticidas & $\begin{array}{l}\text { Termiticidas, inseticidas, rodenticidas, } \\
\text { fungicidas, desinfetantes, herbicidas }\end{array}$ \\
\hline Partículas e fibras & $\begin{array}{l}\text { Impressoras, combustão em geral, ar externo, } \\
\text { deterioração dos materiais, construção/reforma, } \\
\text { limpeza, isolação }\end{array}$ \\
\hline
\end{tabular}

Observa-se, na Tabela 1, que as principais fontes de emissão sempre estão relacionadas com algum produto ou alguma atividade ocupacional. No ambiente, as interações entre os poluentes podem ocorrer, conforme as características físicas, químicas e biológicas das fontes de emissão.

Na tabela 2, apresentam-se os principais meios de infiltração de ar e respectivas causas para esse fato em ambientes internos e externos. 
Tabela 2 - Meios de infiltração de ar e respectivas causas para esse fato em ambientes internos e externos. Fonte: EPA, 2002.

\begin{tabular}{ll}
\hline \multicolumn{1}{c}{ Infiltração de ar } & \multicolumn{1}{c}{ Causas } \\
\hline Interior & Diferença de pressão entre os ambientes \\
\hline $\begin{array}{l}\text { Caixa de escada } \\
\text { Duto do elevador } \\
\text { Conduites }\end{array}$ & \\
Shaft & \\
\hline Duto de VAC* ou forro & Mistura entre os poluentes e o ar através de VAC \\
\hline Perda do duto de VAC & Vazamento nos dutos de VAC \\
\hline Portas e aberturas & Interligação entre os ambientes através de portas e aberturas \\
\hline Exterior & \\
\hline Ar de insuflamento & $\begin{array}{l}\text { Poluentes do ar externo ou do exaustor podem entrar pelo ar de } \\
\text { insuflamento }\end{array}$ \\
\hline Janelas e portas externas & Diferença de pressão externa e interna \\
Rachaduras e fendas & Poluentes do ar podem entrar no edifício através do contato com o solo \\
\hline Infraestrutura & \\
\hline * Ventilação e Ar-Condicionado &
\end{tabular}

$\mathrm{O}$ ar infiltrado pode transportar os poluentes externos aos ambientes internos e viceversa. Neste sentido, a infiltração de poluente do ar é controlada, principalmente, pelas aberturas de portas e de janelas.

A seguir, descrevem-se as principais fontes de poluente do ar, que podem ser biológicas, químicas e físicas:

\subsubsection{Fontes e agentes biológicos}

As principais fontes e agentes biológicos são os ácaros, os animais domésticos, os insetos, os fungos, as bactérias e os vírus.

\subsubsection{1. Ácaros}

Os ácaros (Dermatophagoides) são artrópodes que pertencem à classe dos aracnídeos, que sobrevivem a uma temperatura de $25^{\circ} \mathrm{C}$ e umidade relativa do ar entre 70 e 80\%, segundo Arlain et al. (1990) apud Jones (1999). Os principais locais 
onde os ácaros se desenvolvem são móveis, papeis de parede, carpetes, acolchoados, travesseiros e colchões, alimentando-se basicamente de pele humana naturalmente descamada e de seus componentes como pelos e caspas.

A propriedade alérgica dos ácaros provém de suas fezes, as quais possuem uma proteína situada dentro de seus resíduos intestinais que contém proteína alergizante, geralmente em flocos de 10 a $14 \mu \mathrm{m}$ de diâmetro, as quais podem entrar em suspensão no ar ambiente seja por varredura, aspiração ou processos de ventilação. Estes ácaros e outros assemelhados (Blomya) não respondem por acaricidas conhecidos. (PLATTS-MILLS et al., 1991 apud JONES, 1999).

Os sintomas alérgicos associados a elevadas concentrações de ácaros são falta de ar, chiados do peito, coriza no nariz e nos olhos, entre outros; recomenda-se cobrir colchões e travesseiros, como prevenção destes sintomas, de acordo com Jones (1998).

\subsubsection{Animais domésticos}

Os cães e gatos são os principais animais domésticos que ocasionam doenças alérgicas. Entre os cães e os gatos, os alérgenos encontrados na saliva e na pele, que são transmitidos aos pelos, permanecem suspensos no ar do ambiente interno, por várias horas devido às suas pequenas dimensões. Em uma concentração de $10 \mu \mathrm{g} / \mathrm{g}$ na poeira doméstica, ou 0,002 e $0,02 \mu \mathrm{g} / \mathrm{m}^{3}$ no ar, encontram-se alérgenos prejudiciais à saúde, sendo considerado o valor limite de $8 \mu \mathrm{g} / \mathrm{g}$ de poeira, segundo D’Amato et al. (1994) apud Jones (1999).

\subsubsection{Insetos}

A concentração de alérgenos de baratas "francesinha" (Blatella germânica) ou de barata de esgoto (Periplaneta americana) em residências é mencionada em vários 
estudos de Jones (1999). A principal doença causada por este alérgeno é a asma, provenientes dos corpos e fezes das baratas. Nestes estudos, há correlações positivas entre as concentrações e hospitalizações de crianças por ataque de asma. Além disso, verificou-se que as residências pobres de baixa renda constituem ambientes de maior sensibilização, uma vez que facilitam a proliferação das baratas.

\subsubsection{Fungos, bactérias e vírus}

Os fungos, as bactérias e os vírus são microorganismos vivos geralmente encontrados no ar interno ou transmitidos entre pessoas, diretamente por gotículas através do ar; os quais podem se proliferar nas estações mais quentes do ano com umidade relativa do ar mais elevada. Nos edifícios, eles estão relacionados à presença de matéria orgânica, tais como revestimento de parede e madeira.

A avaliação destes microorganismos é feita por meio de contagem da Unidades de Formação de Colônias de fungos e bactérias (UFCs), segundo Hunter et al. (1996) apud Jones (1999). Em estudos realizados no Reino Unido e na Filadélfia foram encontrados elevados valores de UFCs, sendo os principais fungos: Penicillium, Cladosporium e Aspergillus, e as principais bactérias: Bacillus, Staphylococus, Micrococus e Legionella pneumophila. Os estudos mostraram que os números elevados de $\mathrm{UFC} / \mathrm{m}^{3}$ no ar estavam relacionados com "chiados" relatados pela população, febre em crianças, dificuldade de respiração, dor de cabeça, dor no peito, diarréia e entre outros.

A proliferação de fungos provém de mofo na edificação, sendo este diretamente associado com a presença de umidade na habitação. Como medida de prevenção de umidade, tem-se a elaboração de projetos arquitetônicos adequados, tais como iluminação e ventilação eficientes. 


\subsubsection{Fontes e agentes químicos}

A seguir, apresentam-se as principais fontes e agentes químicos de emissão de poluente do ar em ambientes internos:

\subsubsection{Gases e vapores}

$\mathrm{O}$ dióxido de enxofre $\left(\mathrm{SO}_{2}\right)$ é o gás poluidor mais perigoso, incolor com odor acre facilmente solúvel em água e pode ser oxidado em gotas de água formadas a partir da umidade do ar. A fonte mais comum deste gás é a combustão do petróleo e do carvão, devido a quantidade de enxofre existente nestes materiais; quanto mais enxofre, mais dióxido de enxofre resultará desta combustão. A exposição intensa a este gás pode causar redução aguda da função dos pulmões e exposições em longo prazo podem ocasionar queixas respiratórias crônicas, pode também causar irritação nos olhos e na pele, sendo capaz de destruir o esmalte dos dentes.

Na cidade de Nashville, os médicos constataram o aumento de ataques de asma devido ao dióxido de enxofre no ar; o gás provoca também catarro crônico, enfisemas, falta de ar e fadiga crônica (Aylesworth, 1971).

O monóxido de carbono (CO) é um gás inodoro e tóxico, resultante da reação de carbono e oxigênio, produzido pela combustão incompleta de combustíveis fósseis. Uma das fontes externas do gás é o escape do motor dos carros. Como fontes internas do gás, pode-se citar os aquecedores de água e fogões a gás. Os sintomas mais comuns da inalação crônica deste gás são o declínio no aprendizado e habilidade de planejamento, além da queda dos níveis de atenção e concentração, de acordo com Amitai et al. (1998) apud Jones (1999).

$\mathrm{O}$ dióxido de nitrogênio $\left(\mathrm{NO}_{2}\right)$ é formado através da combinação de nitrogênio e oxigênio durante combustões a temperaturas elevadas. A fonte principal deste gás está associada à operação de equipamentos a gás, aquecedores e fogões a lenha e 
pode ter origem no ar externo. $\mathrm{O} \mathrm{NO}_{2}$ pode causar irritação nas membranas mucosas do pulmão e o aumento das infecções respiratórias. Em estudos realizados por Jones (1999), as concentrações médias em dormitórios e cozinhas foram respectivamente de $39 \mu \mathrm{g} / \mathrm{m}^{3}$ e $63 \mu \mathrm{g} / \mathrm{m}^{3}$, podendo atingir picos de $1880 \mu \mathrm{g} / \mathrm{m}^{3}$.

Os Compostos Orgânicos Voláteis (COVs) são compostos que contêm no mínimo, um átomo de carbono e um átomo de hidrogênio em sua estrutura molecular. $\mathrm{O}$ intervalo do ponto de ebulição destes compostos está entre 50 e $260{ }^{\circ} \mathrm{C}$ (MARONI et al., 1995 apud JONES, 1999) ou entre 0 e $400{ }^{\circ} \mathrm{C}$ (WOLKOFF et al., 1998), por conseguinte um maior desprendimento de gases no ar interno. As principais fontes de COVs são solventes de tintas e adesivos, fragrâncias, plastificantes, produtos de limpeza, carpetes, constituintes de produtos baseados em madeira, utensílios domésticos e produtos para tratamento de pedras e alvenaria.

Entre os componentes dos produtos de limpeza e dos produtos baseados em madeira, encontra-se o aldeído, um elemento volátil, incolor e com odor forte. A inalação e contato direto deste componente podem causar espirros, tosse e irritação dos olhos, sintomas que desaparecem rapidamente.

A exposição de COVs pode gerar sintomas agudos e crônicos principalmente em asmáticos e portadores de doenças respiratórias, sendo os sintomas mais comuns: irritações dos olhos, do trato respiratório e das mucosas de um modo geral. Em elevadas concentrações, muitos COVs são narcóticos e podem deprimir o sistema nervoso central, segundo Maroni et al. (1995) apud Jones (1999). Além disso, a intensidade de odor percebido diminui à medida que se adapta, aumentando a irritação das membranas mucosas com o tempo (WOLKOFF; NIELSEN, 1995).

Os compostos inorgânicos, tais como amônia e ozônio, também são considerados perigosos, uma vez que sofrem reação química com os compostos orgânicos nãosaturados, segundo Weschler (2000) apud Wolkoff e Nielsen (2001). 
O radônio é um gás radiativo, inerte, originário da decomposição do rádio-226 presente em diversos minerais. $\mathrm{O}$ radônio apesar de exalado na respiração produz alguns radioisótopos de vida curta, que são eletricamente carregados e podem ser inalados diretamente ou aderidos a algum material particulado suspenso no ar. Quando inalados tendem a permanecer nos pulmões, podendo causar câncer, de acordo com Cohen (1998) apud Jones (1999).

Em solos e rochas, pode-se encontrar altas concentrações de radônio. Os materiais de construção formados por estes elementos podem liberar o gás radônio no ar interno, ou ainda desprender do solo local e penetrar no edifício através de frestas (JONES, 1999).

\subsubsection{Fontes e agentes físicos}

A seguir, mostram-se as principais fontes e agentes físicos de poluição do ar em ambientes internos:

\subsubsection{Material particulado}

Os materiais particulados são substâncias simples ou compostas, formados por elementos químicos no estado sólido ou líquido e quando suspensos no ar são chamados de aerodispersóides. As fontes de emissão de aerodispersóides são principalmente as indústrias, os automóveis, o solo aderido aos sapatos, a poeira gerada internamente através do desgaste de móveis e utensílios, a fumaça gerada na queima de combustíveis fósseis, a atividade de limpeza, entre outros.

A poeira nos pisos e outras superfícies do edifício contém minerais, metais, fibras têxteis, papel, material de isolamento, partículas de fumaça de tabaco, compostos orgânicos, materiais de fontes biológicas, alérgenos animais e pólen, segundo Wolkoff (1998). 
O tamanho de uma partícula é um parâmetro chave do seu comportamento. Dependendo do seu tamanho irá pousar com mais rapidez, seguirá os movimentos do ar, se depositará em uma determinada parte do sistema respiratório humano e será ressuspensa de uma superfície em que está depositada.

As partículas finas no ar podem absorver os gases venenosos mais comuns, removendo-os, assim, do ar que passam a ser aspiradas para nossos pulmões quando inaladas. Alguns pesquisadores observaram que pode haver uma relação entre o aumento da concentração de aerodispersóide e o aumento do número de casos de pneumonia (AYLESWORTH, 1971). Uma outra relação muito grave entre aerodispersóide e a saúde humana, segundo este mesmo autor, foi apontada que partículas de chumbo no ar podem afetar o sistema nervoso central. E que outra partícula no ar, o cádmio, pode ter relação com as doenças cardíacas.

\subsection{Amianto}

Amianto é o nome designado a silicatos minerais fibrosos, incombustíveis, material muito utilizado em reservatórios de água, telhas, isolantes térmicos, elétricos e acústicos. Os sintomas causados pela exposição intensa ao amianto são irritação de pele, bronquite, câncer de pulmão e asbestose, sendo este último o desenvolvimento lento de fibrose do pulmão, de acordo com Jones (1999).

No Brasil, a comercialização e, em alguns casos, a produção do amianto já foram proibidas permanentemente. Em 21 municípios do Estado de São Paulo, a comercialização do amianto está controlada. Na Cidade de São Paulo, a produção do amianto foi proibida. 


\subsection{Metais pesados}

Os metais pesados são poluentes formados pela combustão dos automóveis e atividades diversas, tais como fundições, indústrias de baterias e petroquímica, além da idade do edifício. Os principais metais pesados são cádmio $(\mathrm{Cd})$, chumbo $(\mathrm{Pb})$, cobre $(\mathrm{Cu})$, manganês $(\mathrm{Mn})$ e zinco $(\mathrm{Zn})$, podendo estar misturados com outros materiais particulados, o que permite trabalhar com índices $(\mu \mathrm{g}$ de metal/g de poeira).

A contaminação por estes metais está relacionada com o tempo de abertura de janelas, a freqüência de limpeza da residência, o emprego de vassoura e ou aspirador a vácuo e também às cores das tintas utilizadas nas paredes (TONG; LAM, 2000).

Os níveis elevados destes metais no corpo humano podem gerar efeitos neurotóxicos e cancerígenos, inclusive em animais (NRIAGU, 1988 apud TONG; LAM, 2000). Estes efeitos são causados pelo acúmulo dos metais pesados, afetando o sistema nervoso central ou ainda serem depositados no sistema circulatório, perturbando o funcionamento de órgãos internos. Podem também atuar como co-fatores em outras doenças.

\subsubsection{Campos eletromagnéticos}

A poluição por campos eletromagnéticos apresenta-se como variável no tempo, que induz em tecidos, densidades decorrentes acima de $1 \mathrm{~A} / \mathrm{m}^{2}$, provocando excitação neural e produzindo efeitos biológicos irreversíveis, tais como, fibrilação cardíaca, de acordo com trabalhos publicados em PRORAD (2002).

Existem divergências com relação à poluição eletromagnética. Porém, segundo o mesmo trabalho, há correlação entre o risco de câncer e a exposição a campos eletromagnéticos, mesmo na freqüência extremamente baixa da rede de distribuição de energia $(50 / 60 \mathrm{~Hz})$, com pequeno aumento de risco de leucemia entre crianças; 
além dos efeitos de aparelhos eletro-eletrônicos específicos (monitor de vídeo), na reprodução humana.

\subsection{Aerodispersóides}

A seguir, apresentam-se os conceitos, as características, a classificação, as propriedades e os aspectos do movimento dos aerodispersóides:

\subsubsection{Definição e formação}

Pode-se definir os aerodispersóides como sendo um sistema constituído por meios de dispersão gasosa onde se encontram materiais particulados sólidos e líquidos. Os aerodispersóides podem ser formados por condensação e por dispersão, distinguindose os sistemas de acordo com a fase dispersa, sólida ou líquida.

Os aerodispersóides formados por condensação são resultantes da condensação de vapores supersaturados, ou da reação entre gases, que leva a um produto não-volátil. Os aerodispersóides formados por dispersão são aqueles resultantes da desintegração mecânica da matéria (pulverização ou atomização de sólidos ou líquidos, ou transferência de poeiras, pólen e bactérias, para o estado de suspensão em virtude da ação de correntes de ar ou vibração).

\subsubsection{Classificação}

A seguir, apresenta-se uma classificação dos materiais particulados citada por Assunção (1998), onde se aplicam os mesmos conceitos para os aerodispersóides, que podem ser divididos em quatro classes: 
- Poeiras.

- Fumos.

- Fumaça.

- Névoas.

\subsubsection{Poeiras}

As poeiras são formadas por partículas sólidas, predominantemente maiores que as coloidais, com diâmetros equivalentes em geral na faixa acima de $1 \mu \mathrm{m}$. Resultam da desintegração mecânica de substâncias inorgânicas ou orgânicas, seja pelo simples manuseio (embalagem), seja em conseqüência de operações de britagem, moagem, trituração, esmerilhamento, peneiramento, usinagem mecânica, fundição, demolição etc.

As poeiras de dimensões maiores são às vezes designadas por particulados ou areias finas, ou ainda, material fragmentado. As poeiras não tendem a flocular, exceto se submetidas a forças eletrostáticas. Precipitam pela ação da gravidade e não se difundem. Como exemplo, a poeira pode ser de: carvão, sílica, amianto, algodão, papel, fibras e entre outras.

\subsubsection{Fumos}

São partículas sólidas, em geral com diâmetros inferiores a $10 \mu \mathrm{m}$, chegando mesmo a 1,0 $\mu \mathrm{m}$. Resultam da condensação de partículas em estado gasoso, geralmente após volatilização de metais fundidos, e quase sempre acompanhada de oxidação. Os fumos tendem a flocular no ar. É o caso dos fumos metálicos, como por exemplo, o cloreto de amônio.

Ao derreter o chumbo, o seu vapor, sublimado em contato com o ar se transforma em óxido de chumbo $(\mathrm{PbO})$, constituindo partículas sólidas extremamente pequenas em 
suspensão no ar. Esses fumos de $\mathrm{PbO}$ são tóxicos, venenos acumulativos, razão por que, nos linotipos, onde são fundidas ligas de chumbo e antimônio, deve-se executar uma instalação de ventilação adequada.

Os fumos de óxidos metálicos produzem a chamada "febre dos fundidores" ou "febre dos latoeiros" que se manifesta acompanhada de tremores, algumas horas após a exposição ao "fumo".

\subsubsection{Névoa}

As névoas são partículas constituídas por gotículas líquidas com diâmetros entre 0,1 (ou mesmo 0,01 $\mu \mathrm{m}$ ) e $100 \mu \mathrm{m}$, resultantes da condensação de vapores sobre certos núcleos, ou da dispersão mecânica de líquidos em conseqüência de operações de pulverização, nebulização, respingos, entre outros.

As neblinas estão compreendidas entre $1,0 \mu \mathrm{m}$ e $50 \mu \mathrm{m}$ e se classificam em mist e em fog, sendo as partículas de um fog (cerração, orvalho, dispersões de água ou gelo) menores que as de um mist (pulverizações, atomizações, espirro de uma pessoa, etc.).

No mist ocorre uma baixa concentração de partículas líquidas de tamanho "grande". Em meteorologia, o mist indica uma leve concentração de partículas de água de tamanho suficientemente grande para que caiam. O fog resulta de reações na atmosfera entre certos hidrocarbonetos, óxidos de nitrogênio e o ozônio, sob a ação da luz solar. Provoca irritação nos olhos, dificuldade respiratória e reduz a visibilidade. Como exemplos, a névoa pode ser de: ácido sulfúrico, ácido crômico, tinta pulverizada, "sprays", entre outros.

\subsubsection{Fumaça}

A fumaça é formada por partículas principalmente sólidas, geradas pela queima de combustíveis fósseis, materiais asfálticos ou madeira. A fuligem é um produto da 
fumaça, que contém partículas líquidas e no caso de madeira e carvão, uma fração mineral (cinzas).

As cinzas são partículas divididas finamente de produtos de queima de carvão e óleo combustível e que são carregadas nos gases de combustão em geral de fornalhas e queimadores de caldeiras.

A fumaça do cigarro causa altíssima mortalidade entre os fumantes, mas os nãofumantes também acabam sendo afetados, quando são fumantes passivos. Lee et al. (2002) afirmam que a concentração de material particulado menor que $10 \mu \mathrm{m}\left(\mathrm{PM}_{10}\right)$ em restaurantes foi maior do que em residências, escritórios, escolas e shoppings, devido à presença de fumaça de cigarro e uso intensivo de gás para cozimento. Estima-se que o fumo passivo cause cerca de 3.000 mortes anuais nos Estados Unidos e que entre 180.000 e 300.000 crianças por ano contraem pneumonia ou bronquite pela exposição à fumaça do cigarro (EPA, 2003).

No Brasil, a Lei Federal No 9.294/96 busca a preservação do ar nos ambientes internos e a proteção aos não fumantes, proibindo o fumo em recinto privado ou público, salvo em área destinada exclusivamente a esse fim, devidamente isolada e com arejamento conveniente. O Decreto № 2.018 de 01/10/1996 regulamentou a Lei $\mathrm{N}^{\circ}$ 9.294, definindo áreas exclusivamente para fumantes, que apresentam adequadas condições de ventilação, natural ou artificial, e de renovação de ar, de forma a impedir o acúmulo de fumaça no ambiente.

\subsubsection{Características}

Os aerodispersóides se apresentam de tamanho variado e de forma irregular. Nos aerodispersóides formados por condensação, as partículas sólidas são freqüentemente agregados provenientes da coagulação de um grande número de partículas primárias de forma esférica ou cristalina regular. Por outro lado, nos aerodispersóides por 
dispersão, a fase dispersa sólida consiste em partículas individuais ou agregadas de formas completamente irregulares (fragmentos).

Em suas pesquisas, Geller et al. (2002) assinalam que no ar interno, os aerodispersóides apresentam aproximadamente 74,3\% ( $\pm 11.0 \%)$ de partículas finas, ou seja, partículas com diâmetro menor ou igual a 2,5 $\mu \mathrm{m}$. E no ar externo, apresentam aproximadamente $61,3 \%( \pm 13,1 \%)$ de partículas finas.

Segundo Tse et al. (2004) assinalam que o material particulado menor que $2,5 \mu \mathrm{m}$ $\left(\mathrm{MP}_{2,5}\right)$ pode estar em suspensão no ar em ambos os estados sólido e líquido, em condições normais de temperatura e pressão. As partículas são emitidas diretamente pelas fontes de emissão ou formadas por reações químicas no ar entre diferentes substâncias.

A Figura 3 mostra graficamente as indicações quanto ao tamanho, à impureza, às partículas típicas, aos métodos de eliminação e aos tipos de radiação nos comprimentos de onda para os aerodispersóides, os vapores e os gases.

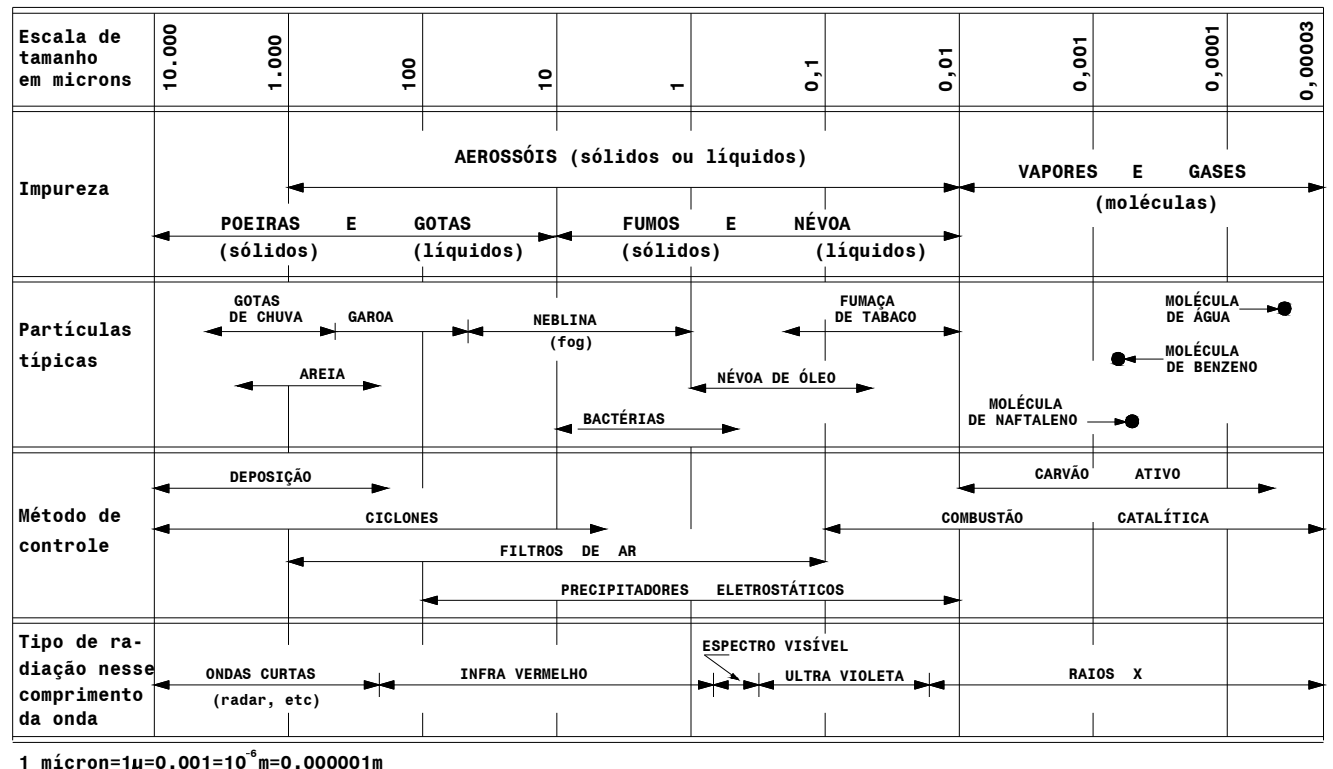

Figura 3 - Impurezas em suspensão no ar, partículas típicas, método de controle, tipo de radiação nesse comprimento de onda. Fonte: Mesquita et al., 1988. 


\subsubsection{Propriedades dos aerodispersóides}

As propriedades que controlam o comportamento físico e químico das partículas individuais em um sistema de aerodispersóides incluem (1) o tamanho ou diâmetro aerodinâmico, (2) a distribuição de tamanho, (3) a forma, (4) a massa específica, (5) as características superficiais como pressão de vapor ou carga elétrica e (6) a composição química.

Chao et al. (2003) afirmam que os principais parâmetros da qualidade do ar em ambientes internos, além das propriedades dos aerodispersóides mencionadas acima, são a taxa de deposição e o coeficiente de penetração. A difusão e o impacto são os melhores mecanismos para diminuir a concentração dos aerodispersóides durante o processo de filtragem, a fim de reduzir a taxa de deposição e o coeficiente de penetração, segundo estes mesmos autores.

Segundo Allen (1997) apud Almeida (2005), a definição de diâmetro aerodinâmico é o diâmetro de uma esfera de densidade unitária $\left(\rho_{\mathrm{p}}=1 \mathrm{~g} / \mathrm{cm}^{3}\right)$, a qual possui a mesma velocidade de sedimentação da partícula em questão.

Para Abadie et al. (2001), além das fontes de poluição interna, a concentração dos aerodispersóides pode ser influenciada pela infiltração de ar, deposição ou ressuspensão de partículas e também pela troca de ar. As partículas maiores que 5,0 $\mu \mathrm{m}$ podem sofrer ação de forças gravitacionais, enquanto, as partículas entre 0,7 e $1,0 \mu \mathrm{m}$ podem ser influenciadas por forças eletrostáticas.

Na Tabela 3 apresentam-se os principais diâmetros médios aerodinâmicos de partículas para vários tipos de aerodispersóides. 
Tabela 3 - Tamanho ou diâmetro aerodinâmico dos principais aerodispersóides. Fonte: Mesquita et al., 1988.

\begin{tabular}{|c|c|}
\hline Aerodispersóides & Diâmetro médio da partícula $(\mu \mathrm{m})$ \\
\hline Cabelo humano & $50-200$ \\
\hline Limite de visibilidade pelo olho humano & $10-40$ \\
\hline \multicolumn{2}{|l|}{ Poeiras, Fumos e Fuligens } \\
\hline Atmosférica & 0,5 \\
\hline Alumínio & 2,2 \\
\hline Ar de mineração & 0,9 \\
\hline Fumo de álcalis & $1-5$ \\
\hline Fumo de cloreto de amônio & $0,05-0,1-1,0$ \\
\hline Cimento & $0,5-10-50$ \\
\hline Carvão & $5-10$ \\
\hline Ferro-manganês ou sílica & $0,1-1$ \\
\hline Ar em fundições & 1,2 \\
\hline Fumaça de central térmica & $0,1-3$ \\
\hline Ferro (ferro gusa) & $0,1-10$ \\
\hline Óxido de ferro & $0,5-2$ \\
\hline Cal & $1-50$ \\
\hline Corte de mármore & 1,5 \\
\hline Pigmentos & $0,2-2$ \\
\hline Jato de areia & 1,4 \\
\hline Súlica & $1-10$ \\
\hline Talco & 10 \\
\hline Fumaça de tabaco & 0,2 \\
\hline Fumo de óxido de zinco & 0,05 \\
\hline Zinco (jateado) & 15 \\
\hline Zinco (condensado) & 2 \\
\hline \multicolumn{2}{|l|}{ Névoas } \\
\hline Fog atmosférico & $2-15$ \\
\hline Acido sulfúrico & $0,5-15$ \\
\hline \multicolumn{2}{|l|}{ Organismos vivos } \\
\hline Pólen & $5-10$ \\
\hline Bactérias & $0,2-20$ \\
\hline Fungos & $1-10$ \\
\hline
\end{tabular}

A taxa de deposição de partículas sobre superfícies internas é um importante parâmetro para determinar o grau de exposição humana dos aerodispersóides em um ambiente. Esta taxa é função de muitos fatores, incluindo o tamanho das partículas, características das superfícies, volume do ambiente e velocidade do ar. A operação do sistema de ar-condicionado pode influenciar a deposição de partículas sobre as superfícies internas devido ao movimento de ar. Também, em lugares que usam filtros, portáteis ou montados nos dutos de ventilação, aumentam ainda mais a taxa de deposição, segundo Wallace (2004).

Segundo Mesquita et al. (1988), uma propriedade importante das partículas finas é o rápido aumento na área superficial por unidade de massa com o decréscimo do 
tamanho. Essa característica leva a um aumento da taxa de reação química e um aumento no risco de inalação.

Outra propriedade dos aerodispersóides é a carga eletrostática representada pelo excesso (-) ou deficiência (+) de elétrons sobre a partícula. A maioria das partículas finas tem carga adquirida naturalmente pela transferência de elétrons durante contato ou separação, ou devido à difusão de íons. Pode-se assumir que essa carga reside sobre a superfície da partícula em um filme de umidade ou gás adsorvido. O número de cargas adquiridas pelas partículas é limitado, e depende do meio que envolve as partículas. No caso de ar seco, é cerca de $1,6 \times 10^{10}$ elétrons $/ \mathrm{cm}^{2}$ (MESQUITA et al., 1988).

Outra propriedade importante das partículas finas, conforme Mesquita et al. (1988), é a adsorção, isto é, o revestimento das partículas finas por um filme superior de gás mantido por forças elétricas ou de valência química originada na superfície das moléculas. A quantidade de gás ou vapor que pode ser adsorvido sobre a superfície da partícula é diretamente proporcional à superfície exposta e esse fato pode ser usado para medir tamanho de partículas sobre certas condições. Muitas características superficiais de pequenas partículas incluindo carga elétrica, adesão e evaporação são modificadas pela presença de gases adsorvidos.

A propriedade de adesão dá-se quando uma camada de líquido é espalhada entre superfícies em contato, produzindo forças de adesão em proporção à tensão superficial do líquido e ao raio de curvatura da superfície líquida molhante. A umidade do ar favorece a adesão. O fenômeno de adesão está relacionado com as forças de Van Der Waals ou forças intermoleculares dos elétrons, carga eletrostática, campos externos - como na precipitação eletrostática, pontos de contato e rugosidade da superfície de aderência.

A propriedade da dispersão da luz para um aerodispersóide provém da falta de homogeneidade, como poeira ou gotículas d'água dispersadas, de um meio fluido. A dispersão é freqüentemente acompanhada pela absorção e ambas removem energia 
do raio luminoso. A resposta quantitativa do raio atenuado pode servir para caracterizar o tamanho das partículas.

Outra importante propriedade dos aerodispersóides é a densidade de uma partícula formada por dispersão de um sólido, que será a mesma do material que a originou. Se ela, subseqüentemente, sofrer oxidação superficial ou hidratação, ou se ela aglomerar-se, sua massa específica variará. Quando duas ou mais partículas sólidas não-porosas se juntam, a partícula resultante terá uma forma geométrica diferente que inclui espaços ocos. Por isso, a massa específica da partícula resultante será menor do que as das partículas originais (MESQUITA et al., 1988).

\subsection{Ambientes Internos}

Segundo Roulet (2001), os sistemas de ventilação e de condicionamento de ar são concebidos para prover ar com níveis adequados de temperatura e umidade, livre de concentrações perigosas de poluente, proporcionando sensações confortáveis aos usuários. Porém, a falta de manutenção destes sistemas pode afetar a qualidade do ar interno, quando não for dada a devida importância aos processos de ventilação necessários aos ambientes. Estes processos tipicamente incluem a tomada de ar externo, condicionamento e mistura do ar interno, boa distribuição do ar no ambiente e renovação do ar.

A importância da ventilação no controle da SED, conforme Assunção (1997), além de garantir a qualidade do ar em ambientes interiores, pois altera a presença de gases e partículas, também diminui os sintomas de doenças apresentados pelos usuários nas edificações.

Segundo Hansen (1991), diferentemente da SED, as Doenças Relacionadas aos Edifícios (DRE) são aquelas relacionadas a uma infecção verdadeira, e não temporária, dos usuários. As DRE são representadas por: asma, infecções bacteriológicas, virais ou por fungos, broncoconstrição, bronquite crônica, câncer 
bronquial, pneumoconioses, efisema, alveolite, câncer pulmonar, entre outros. Estas doenças estão diretamente relacionadas às condições do edifício.

\subsubsection{Sistemas de ar-condicionado}

Uma instalação de condicionamento de ar é um conjunto de máquinas, tubulações e partes complementares capazes de realizar o controle, simultaneamente, da temperatura, da umidade, da movimentação e da pureza em um ambiente interno.

$\mathrm{Na}$ Figura 4, apresenta-se o sistema de ar-condicionado com equipamento do tipo self-contained, com condensador de ar acoplado.
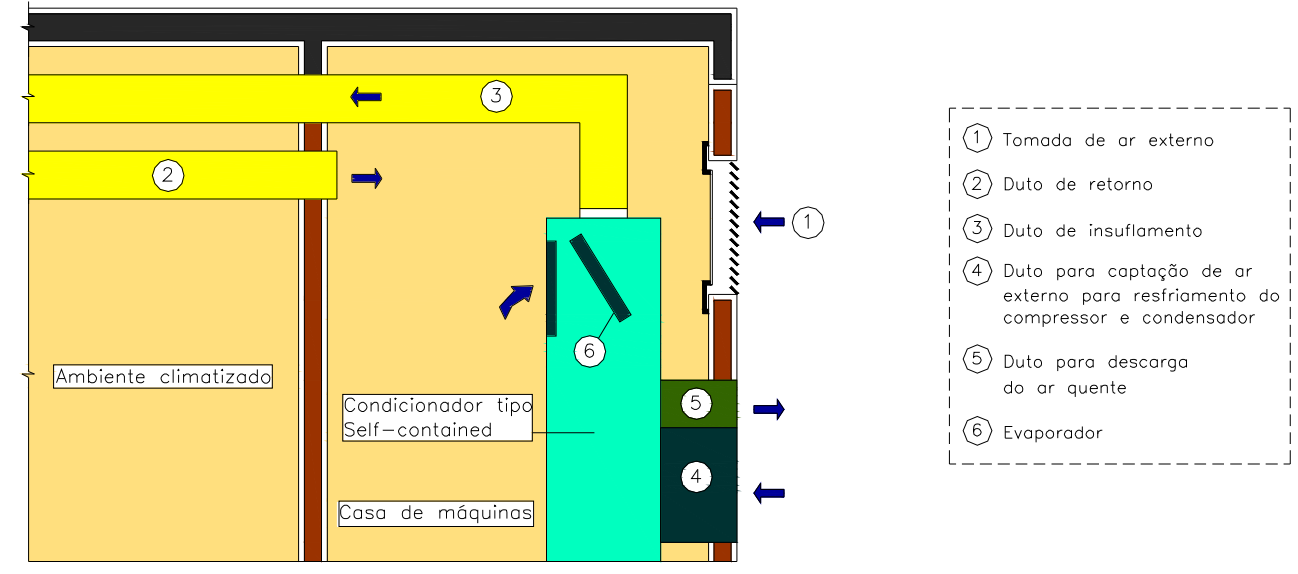

Figura 4 -Sistema de ar-condicionado com equipamento do tipo self-contained, com condensador a ar acoplado.

Os modelos de equipamentos para os sistemas de ar-condicionado são bastante variáveis e o projeto é que definirá o tipo a ser usado. Os sistemas se dividem em duas modalidades de expansão: direta ou indireta. Os de expansão direta são aqueles em que o gás refrigerante é o responsável pelo resfriamento do ar injetado no ambiente, como ocorre nos aparelhos de janela e nos equipamentos do tipo split, não tendo normalmente renovação de ar. Os de expansão indireta são aqueles em que o 
gás refrigerante resfria a água que circula pelo sistema, sendo esta a responsável pelo resfriamento do ar. Esse último é o funcionamento das centrais de água gelada.

O aparelho de janela é assim designado por serem adaptáveis às janelas ou às aberturas nas paredes. O aparelho é construído de maneira a deixar o evaporador no circuito do ar a ser refrigerado (o ambiente) e o condensador em contato com o exterior a fim de ceder o calor contido no fluido. Um filtro de espuma de nylon ajuda a retirar poeira e fumos do ar. Estes aparelhos estão disponíveis em versões de menor potência, na faixa de 1,75 mil kcal/h, até os de grande capacidade, com 7,60 mil $\mathrm{kcal} / \mathrm{h}$

O aparelho do tipo split permite a instalação das partes ruidosas em áreas externas, deixando apenas a unidade evaporadora no interior dos ambientes. Estas unidades evaporadoras podem ser instaladas no forro ou em paredes. A ligação entre as partes interna e externa é feita por meio de dutos e quanto maior à distância, maiores serão as perdas do sistema. Muitos aparelhos não prevêem a troca de ar nos ambientes.

Assimakopoulos e Helmis (2004) afirmam que os edifícios comerciais construídos nas últimas décadas possuem poucas aberturas (janelas), para diminuir o custo com a energia elétrica proveniente do sistema de ar-condicionado. No entanto, estes sistemas apresentam outro aspecto essencial que deve ser focado: a manutenção como forma de melhorar a qualidade do ar interno proporcionado pelo sistema.

Como para qualquer sistema desta natureza, a manutenção tem por objetivo preservar os equipamentos mecânicos e eletroeletrônicos em boas condições de operação e preservar sua integridade física, prevenindo o desgaste prematuro dos componentes e substituindo as partes gastas ou defeituosas, de forma a manter permanentemente o sistema em condições normais de operação.

Um sistema de ar-condicionado movimenta um grande volume de ar, que transporta considerável carga de poluente de toda natureza, tanto provenientes do exterior 
quanto gerada no próprio ambiente, pelos usuários, equipamentos, mobiliários, entre outros.

A deposição de aerodispersóides diminui aproximadamente pela metade, quando o aparelho de ar-condicionado está ligado. As possíveis razões são: aumento da superfície de contato através dos dutos e outros componentes do sistema, aumento da velocidade de ar no ambiente interno e aumento da energia cinética com a turbulência, segundo Howard-Reed et al. (2003).

O sistema de ar-condicionado dispõe essencialmente de dois recursos para controlar a concentração dos poluentes no ambiente:

- Filtros de ar para reter mecanicamente os aerodispersóides trazidos pelo ar de renovação e pelo ar recirculado do ambiente.

- Renovação do ar ambiente para diminuir a carga sobre os filtros e reduzir a concentração dos aerodispersóides que não podem ser retidos nos filtros convencionais.

Os filtros devem ser operados até um certo limite de carregamento, além do qual há o risco de arraste no fluxo de ar dos poluentes acumulados, ao mesmo de rompimento do elemento filtrante.

Cabe à manutenção cuidar e manter os filtros corretamente instalados e proceder à sua substituição ou regeneração em tempo hábil. O melhor indicador do grau de carregamento de um filtro e a necessidade de sua substituição, principalmente em se tratando de filtros de alta eficiência de custo relativamente elevado, é a perda de carga do ar medida por manômetro diferencial. A aparência de "filtro sujo" não é indicação confiável do grau de carregamento do filtro.

A existência de filtros não garante a limpeza do sistema e a boa qualidade do ar. A não ser no caso dos filtros de alta eficiência (A1, A2 e A3), para partículas menores que $1 \mu \mathrm{m}$, utilizados em salas com controle de teor de poeira, zonas assépticas de 
hospitais e salas limpas. Os filtros comumente utilizados (G0, G1 e G2), mesmo os de melhor eficiência, deixam passar grande parte dos poluentes particulados menores que $5 \mu \mathrm{m}$ carregados pelo ar.

Estes poluentes se acumulam nas paredes do condicionador, na serpentina molhada e na bandeja de recolhimento de condensados, onde a água mal drenada e acumulada pode formar lodo e se tornar caldo de cultura de microorganismos, fungos e outros poluentes, os quais arrastados pelo ar e reintroduzidos no ambiente, tornam-se fontes tradicionais e perigosas de poluição. Estes poluentes depositam-se também nas paredes internas dos dutos, tornando-se mais um agente permanente de contaminação do ambiente. É, portanto, responsabilidade da manutenção proceder à limpeza rigorosa e periódica das partes internas do condicionador, principalmente da bandeja de condensados, utilizando se necessário, produtos químicos aprovados e disponíveis no mercado que combatem a formação de lodo e a proliferação de microorganismos.

Deve-se também verificar as condições das partes do sistema e proceder a sua limpeza completa, valendo-se dos sistemas robotizados de inspeção e limpeza atualmente disponíveis no mercado, quando não há possibilidade de acesso pelo lado externo. Este procedimento é particularmente importante em instalações antigas que operam muitos anos com filtros precários e acumularam nos dutos grandes quantidades de poluente.

A determinação da freqüência das limpezas e das verificações deve ser definida pela manutenção. Esta freqüência será tanto maior quanto menor for a efetividade da filtragem, cabendo analisar se menores custos de manutenção não compensariam o custo da substituição dos filtros por outros de melhor eficiência.

A taxa de renovação prevista em projeto, admitida correta, pode não se efetivar na prática, seja por deficiência no balanceamento inicial da instalação seja por outros motivos tais como mudança de layout ou taxa (tipo) de ocupação, existência de equipamentos poluidores não previstos no projeto, controles por volume variável que 
não compensem a redução da vazão de ar exterior quando se reduz a vazão total do sistema, etc.

Embora as causas da eficiência de renovação sejam geralmente fora do controle da manutenção, é desejável que esta tenha condições técnicas para medir a taxa de ar exterior e confrontá-la com a prevista em projeto, detectando e apontando ao usuário, possíveis falhas ou modificações de projeto. Ou ainda outras falhas que possam ter impedido a obtenção da vazão prevista ou tornando esta insuficiente.

\subsubsection{Sistemas de ventilação natural}

A ventilação natural é o deslocamento controlado ou intencional de ar através de aberturas específicas como portas, janelas, lanternins e dispositivos para ventilação. Difere da infiltração que é o movimento de ar não-controlado, através de frestas de janelas e portas, de paredes, pisos e forros, e por outras aberturas existentes. Segundo Yang et al. (2005), a ventilação natural, além de reduzir o custo de construção e de operação nos edifícios, pode manter baixo o nível de concentração dos poluentes, em locais onde a taxa de ventilação é mantida constante.

O fluxo de ar que entra e sai de um edifício por infiltração ou ventilação natural depende da diferença de pressão entre as partes interior e exterior da estrutura e da resistência ao fluxo de ar oferecida pelas aberturas e frestas no edifício. A diferença de pressão exercida sobre o edifício pelo ar pode ser causada pelo vento ou pela diferença de densidade do ar de fora e dentro do edifício.

O efeito de diferença de densidade, conhecido como "efeito chaminé", é freqüentemente o principal fator. Quando a temperatura dentro do edifício é maior do que a exterior, produz-se uma pressão interna negativa e um fluxo de ar entra pelas partes inferiores, o que causa uma pressão interna positiva e um fluxo de ar que sai nas partes superiores do edifício. O inverso ocorre quando a temperatura interior é 
menor que a do exterior. Numa determinada altura no interior do edifício, existe uma zona neutra onde não há diferença de pressão dentro e fora.

Quando a diferença de pressão é o resultado da pressão do vento, o ar entra no edifício através de aberturas localizadas na direção do vento, e sai através de aberturas localizadas em direção oposta.

As forças naturais disponíveis para movimentação do ar são a força do vento e as diferenças de temperatura entre o ar interior e o ar exterior do edifício. O movimento de ar pode ser causado por essas forças agindo individual ou combinadamente, dependendo das condições atmosféricas, do projeto e da localização do edifício. Os resultados obtidos da ventilação natural variarão de tempos em tempos, devido à variação na velocidade e na direção do vento, e na diferença de temperatura. $O$ arranjo, a localização, o controle das aberturas de ventilação podem ser tais que as duas forças agem cooperativamente, e não em oposição.

\subsubsection{Sistemas de ventilação diluidora}

A ventilação diluidora é o método de insuflar ar em um ambiente ocupado, de exaurir ar desse ambiente, ou ambos, a fim de promover uma redução na concentração de poluente nocivo. Essa redução ocorre, uma vez que, ao ser introduzido ar limpo, ou não poluído, em um ambiente contendo uma certa massa de um determinado poluente, faz-se com que essa massa seja dispersa ou diluída em um volume maior de ar, reduzindo, portanto, a concentração desses poluentes. A primeira observação a ser feita é a de que esse método de ventilação não impede a emissão dos poluentes para o ambiente de trabalho, mas simplesmente dilui esses poluentes.

Em suas pesquisas, Wargocki et al. (2002), Kosonen e Tan (2004) assinalam que aumentando a ventilação, a troca de ar e reduzindo as fontes de emissão, a quantidade de pessoas insatisfeitas tende a diminuir. Assim, o sistema de ventilação geral diluidora, quando utilizado de forma correta, pode proporcionar: 
- Proteção à saúde do usuário - reduzindo a concentração de poluente nocivo abaixo de um certo limite de tolerância.

- Segurança ao usuário - reduzindo a concentração de poluente explosivo ou inflamável abaixo dos limites de explosividade e inflamabilidade.

- Conforto e eficiência ao usuário - pela manutenção de temperatura e da umidade do ar do ambiente.

- Proteção aos materiais ou equipamentos - mantendo condições atmosféricas adequadas (impostas por motivos tecnológicos).

A aplicação, com sucesso da ventilação geral diluidora, depende das seguintes condições:

- O poluente gerado não deve estar presente em quantidade que exceda a que pode ser diluída com um adequado volume de ar.

- A distância entre os ocupantes e o ponto de geração do poluente deve ser suficiente para assegurar que os ocupantes não estarão expostos as concentrações médias superiores aos limites de tolerâncias.

- A toxicidade do poluente deve ser baixa (deve ter um alto limite de tolerância).

- O poluente deve ser gerado em uma quantidade razoavelmente uniforme.

A ventilação geral diluidora, além de não interferir com as operações e processos do ambiente interno, é mais vantajosa que a ventilação local exaustora, nos locais onde estão sujeitos a modificações constantes, e quando as fontes de emissão de poluente se encontrarem distribuídas pelo local.

A ventilação geral diluidora pode não ser vantajosa, pelo custo de operação elevado, contudo seu custo de instalação é relativamente baixo quando comparado com o da ventilação exaustora. É conveniente a instalação de sistemas de ventilação geral diluidora quando há interesse na movimentação de grandes volumes de ar. 
Diversas razões levam à não utilização freqüente da ventilação geral diluidora para poeiras e fumos. A quantidade de material gerado é usualmente muito grande e são difíceis de se obter dados seguros sobre taxa de geração de poeiras e fumos. Além disso, o material pode ser muito tóxico, requerendo, portanto, uma excessiva quantidade de ar de diluição.

\subsubsection{Sistemas de ventilação local exaustora}

A ventilação local exaustora tem como objetivo principal a proteção da saúde do ocupante, uma vez que capta os poluentes de uma fonte (vapores, poeira tóxica, entre outras) antes que os mesmos se dispersem no ar do ambiente, ou seja, antes que atinjam a zona de respiração. De uma forma indireta, a ventilação local exaustora também influi no bem-estar, na eficiência e na segurança do usuário. Também no que se refere ao controle da poluição do ar, a ventilação local exaustora tem papel importante. A fim de que os poluentes emitidos por uma fonte possam ser tratados em um equipamento de controle de poluente (filtros, lavadores, etc), eles têm de ser captados e conduzidos a esses equipamentos, e isso, em um grande número de casos, é realizado por um sistema de ventilação local exaustora.

A qualidade do ar interno em regime permanente pode ser caracterizada pelo coeficiente de remoção dos poluentes, o qual é definido como sendo a relação entre a concentração das partículas em um determinado local e a concentração das partículas na saída do exaustor, conforme Behne (1999). Quando os valores destes coeficientes são menores que 1.0, indicam que o ar está com qualidade boa; quando os valores são maiores que 1.0, indicam que algum poluente do ambiente não está sendo removido.

Basicamente um sistema de ventilação local exaustora, consiste em pelo menos um dos seguintes componentes:

- Captor: ponto de entrada dos gases a serem exauridos pelo sistema. 
- Sistema de dutos: responsáveis pelo transporte dos gases captados.

- Ventilador: responsável pelo fornecimento da energia necessária à movimentação dos gases (fornece um diferencial de pressão entre o captor e a saída do sistema).

- Equipamento de controle de poluição do ar: destina-se a reter os poluentes, impedindo seu lançamento na atmosfera; é utilizado quando necessário.

O captor é o ponto de entrada dos gases no sistema de ventilação local exaustora. Um captor estará completamente dimensionado quando tem determinado:

- Sua forma (enclausurado ou externo) e suas dimensões.

- Sua posição relativa à fonte de poluição.

- A vazão a ser exaurida para captura completa dos poluentes.

- A energia necessária para movimentar os gases exauridos para dentro dele.

Como é observado, o ar flui de um ponto de maior pressão para um ponto de menor pressão. Para escoar o ar ou os gases que estão junto à fonte dentro do captor, tem que estabelecer um diferencial de pressão entre o captor e o ar externo. Esse diferencial de pressão é obtido por meio do uso de um ventilador e com um gasto de energia. A seguir, apresenta-se, Na Figura 5, a configuração da máxima convergência à jusante no plano da vena-contracta, cuja seção é inferior à seção do duto.

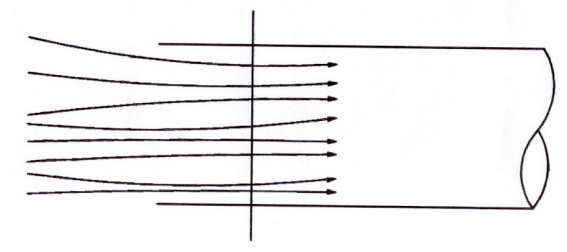

Figura 5 - Configuração da máxima convergência à jusante do plano da vena-contracta, para um fluxo de ar entrando no duto. Fonte: Mesquita et al., 1988. 


\subsection{Efeitos à Saúde}

Em suas pesquisas, Wong e Huang (2004) observaram alguns sintomas em usuários de ambientes internos que tem provavelmente como origem à ventilação natural, antes atribuídas exclusivamente ao ar-condicionado, tais como: sensibilidade nos olhos, obstrução nasal, coriza, infecção na pele, dor de cabeça, sonolência, chiado no peito, gripe, entre outros, conforme a Figura 6.

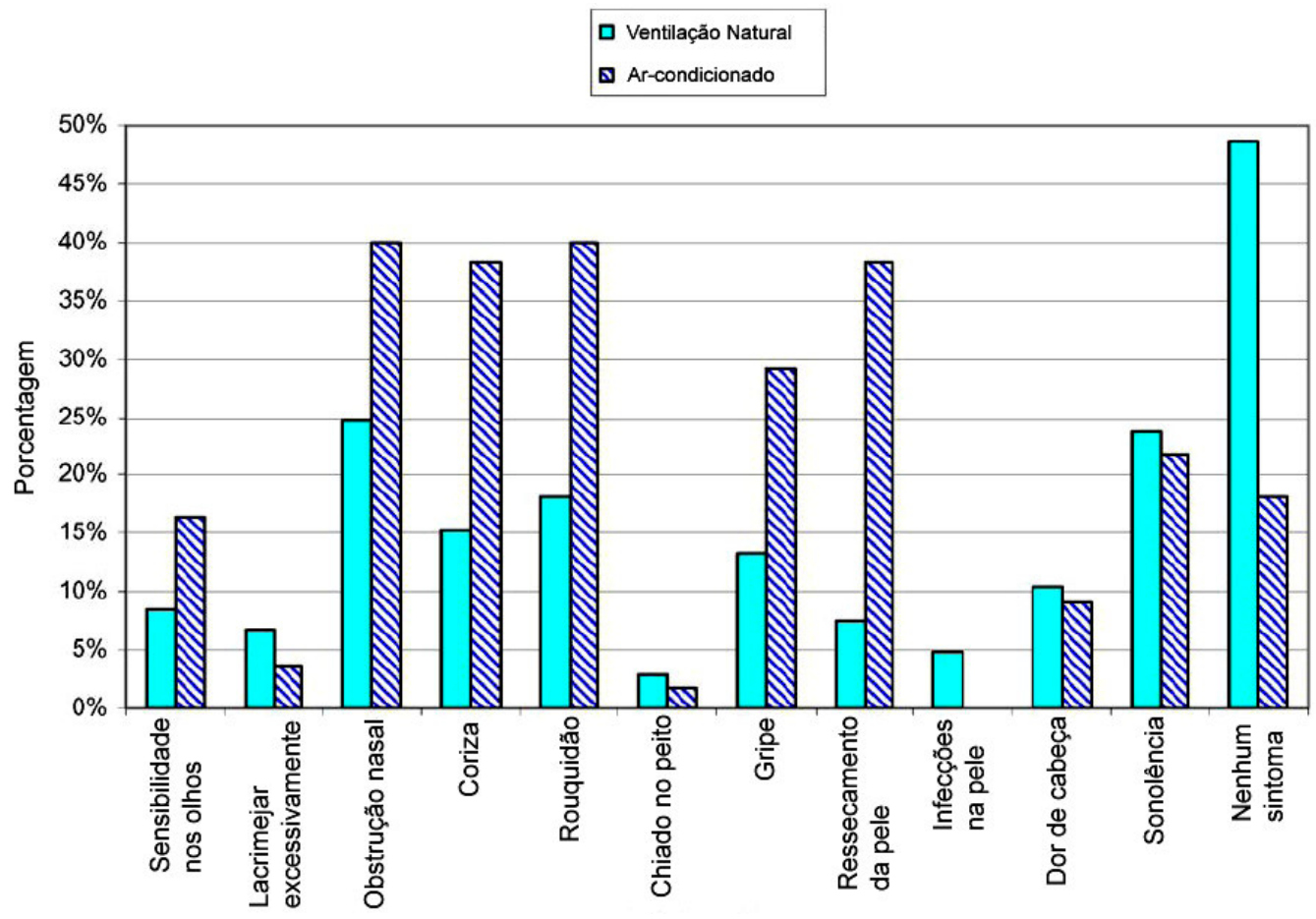

Figura 6 - Porcentagens de ocorrência dos sintomas em usuários de edifícios doentes, em função do ar-condicionado e da ventilação natural. Fonte: Wong e Huang., 2004.

Na Figura 6, observam-se as porcentagens de ocorrência dos sintomas em usuários de edifícios doentes, em função do uso de ar-condicionado ou ventilação natural. $\mathrm{Na}$ ventilação natural, os usuários reclamam principalmente dos seguintes sintomas: lacrimejar excessivamente, chiado no peito, infecções na pele, dor de cabeça e sonolência. No condicionamento do ar, os usuários reclamam principalmente dos 
sintomas: sensibilidade nos olhos, obstrução nasal, coriza, gripe, ressecamento da pele e rouquidão.

Segundo os autores citados, as porcentagens em que os sintomas não aparecem foram de $49 \%$ para a ventilação natural e $18 \%$ para o condicionamento de ar, atribuindo esse fato ao aumento da concentração de poluente no ar, como os aerodispersóides, os compostos orgânicos voláteis, o monóxido de carbono, entre outros.

\subsubsection{Toxicidade}

Toxicidade é a capacidade de uma substância química produzir um efeito nocivo quando interage com um organismo vivo. A toxicidade de uma substância depende da dose e/ou do sistema biológico de cada um. O dano é produzido em resposta a toxicidade de uma substância.

O modelo de dose-resposta é um modelo logístico, ou seja, um conjunto de atividades relacionadas com a conservação do potencial humano, através de medidas preventivas e de recuperação. Em Toxicologia, este modelo é freqüentemente utilizado no estudo do comportamento de determinadas substâncias químicas, segundo a dose aplicada.

Em suas pesquisas, Tse et al. (2004) observaram que as concentrações de aerodispersóides menores que 2,5 $\mu \mathrm{m}$ e $10 \mu \mathrm{m}$, para o ambiente interno e externo, apresentaram relação com o número de casos de internação hospitalar, taxa de mortalidade e restrição das atividade diárias. Os principais efeitos devido à concentração de materiais particulados $\left(\mathrm{MP}_{10}\right.$ e $\left.\mathrm{MP}_{2,5}\right)$, segundo esses autores, são as pneumonias, a obstrução crônica dos pulmões e a isquemia do coração.

Na Tabela 4, identificam-se os coeficientes de dose-resposta para os casos de internação hospitalar, taxa de mortalidade e restrição das atividades diárias devido à concentração de material particulado $\left(\mathrm{MP}_{10}\right.$ e $\left.\mathrm{MP}_{2,5}\right)$. 
Tabela 4 - Coeficientes de dose-resposta para os efeitos devido à concentração de material particulado $\left(\mathrm{MP}_{10}\right.$ e $\left.\mathrm{MP}_{2,5}\right)$. Fonte: Tse et al, 2004.

\begin{tabular}{|c|c|c|c|}
\hline Referência & Localização & Poluentes & $\begin{array}{l}\text { Coeficiente de dose-resposta }\left(n^{\circ}\right. \\
\left.\text { de casos } / \mu \mathrm{g} . \mathrm{m}^{-3}\right)\end{array}$ \\
\hline \multicolumn{4}{|l|}{ Internações } \\
\hline \multirow[t]{2}{*}{ Burnett et al. (1999) } & Canadá & $\mathrm{MP}_{10}$ & 0,019 \\
\hline & & $\mathrm{MP}_{2,5}$ & 0,033 \\
\hline \multirow[t]{10}{*}{ Wong et al. (1999) } & Hong Kong & $\mathrm{MP}_{10}$ & Sistema Circulatório \\
\hline & & & 0,004 (todas as idades) \\
\hline & & & Sistema Respiratório \\
\hline & & & 0,006 (todas as idades) \\
\hline & & $\mathrm{MP}_{2,5}$ & Sistema Circulatório \\
\hline & & & 0,002 (entre 15 e 64 anos) \\
\hline & & & 0,004 (outros) \\
\hline & & & Sistema Respiratório \\
\hline & & & 0,004 (entre 15 e 64 anos) \\
\hline & & & 0,01 (outros) \\
\hline \multicolumn{4}{|l|}{ Mortalidade } \\
\hline Ostro (1994) & Indonésia & $\mathrm{MP}_{10}$ & 0,0000672 \\
\hline Chock et al. (2000) & USA & $\mathrm{MP}_{10}$ & 0,0056 \\
\hline Schwartz et al. (1996) & USA & $\mathrm{MP}_{10}$ & 0,0015 (média de dois dias) \\
\hline \multirow[t]{7}{*}{ Hoek et al. (2000) } & Holanda & $\mathrm{MP}_{10}$ & 0,0008 (todos os casos de doenças) \\
\hline & & & Sistema Circulatório \\
\hline & & & 0,015 \\
\hline & & & Pneumonia \\
\hline & & & 0,0167 \\
\hline & & & Obstrução crônica dos pulmões \\
\hline & & & 0,0096 \\
\hline \multirow[t]{7}{*}{ Schwatz et al. (1996) } & USA & $\mathrm{MP}_{2,5}$ & 0,008 \\
\hline & & & Isquemia do coração \\
\hline & & & 0,021 \\
\hline & & & Obstrução crônica dos pulmões \\
\hline & & & 0,033 \\
\hline & & & Pneumonia \\
\hline & & & 0,04 \\
\hline Cifuentees et al. (2000) & Chile & $\mathrm{MP}_{2,5}$ & 0,000124 \\
\hline Borja-Aburto et al. (1998) & México & $\mathrm{MP}_{2,5}$ & 0,0013 \\
\hline \multicolumn{4}{|l|}{ Restrição de atividades diária } \\
\hline \multirow[t]{3}{*}{ Ostro and Rothschild (1989) } & USA & $\mathrm{MP}_{10}$ & 0,0475 \\
\hline & & & 0,0303 \\
\hline & & & 0,0213 \\
\hline \multirow[t]{3}{*}{ Ostro (1994) } & Indonésia & $\mathrm{MP}_{2,5}$ & 0,076 \\
\hline & & & 0,048 \\
\hline & & & 0,034 \\
\hline
\end{tabular}


Chao e Wong (2002), identificaram dezessete elementos inorgânicos na composição dos $\mathrm{MP}_{2,5}$, sendo considerados tóxicos para os usuários de um ambiente externo e interno, conforme Figura 7.

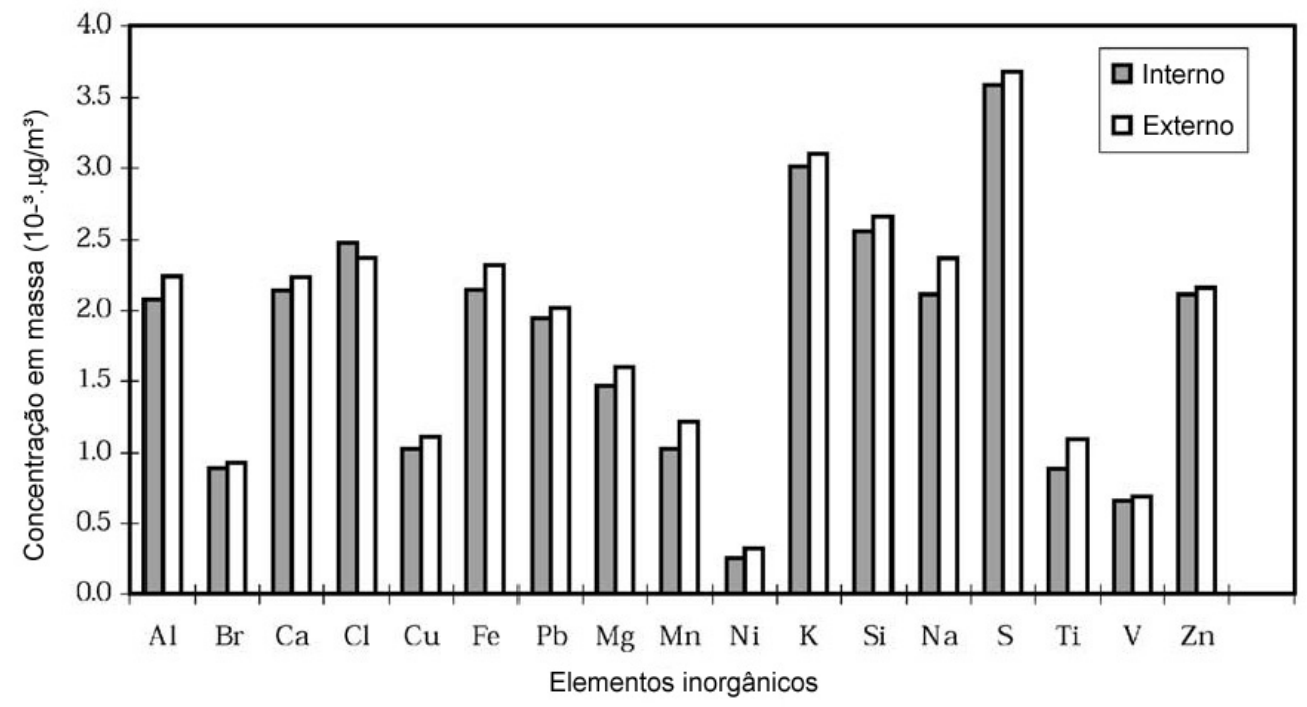

Figura 7 - Concentração em massa para os 17 elementos inorgânicos presentes nos materiais particulados $\left(\mathbf{M P}_{2,5}\right)$, em ambientes interno e externo. Fonte: Chao e Wong. (2002).

$\mathrm{Na}$ Figura 7, os autores citados, observaram que as concentrações em massa presentes nos $\mathrm{MP}_{2,5}$ ficaram entre: $3,7 \times 10^{-3} \mu \mathrm{g} / \mathrm{m}^{3}$ e $2,6 \times 10^{-3} \mu \mathrm{g} / \mathrm{m}^{3}$ para o enxofre, o potássio e o silício, $2,5 \times 10^{-3} \mu \mathrm{g} / \mathrm{m}^{3}$ e $1,4 \times 10^{-3} \mu \mathrm{g} / \mathrm{m}^{3}$ para o alumínio, o cálcio, o cloro, o ferro, chumbo, o magnésio, o sódio e o zinco, $1,3 \times 10^{-3} \mu \mathrm{g} / \mathrm{m}^{3}$ e $0,7 \times 10^{-3}$ $\mu \mathrm{g} / \mathrm{m}^{3}$ para o bromo, o cobre, o manganês, o titânio e o vanádio, e menor que $0,6 \times 10^{-}$ ${ }^{3} \mu \mathrm{g} / \mathrm{m}^{3}$ para o níquel.

A seguir, na Figura 8, segundo os mesmos autores, apresentam-se as concentrações em massa para os dezessete elementos inorgânicos presentes nos $\mathrm{MP}_{10} \mathrm{em}$ ambientes internos e externos. 


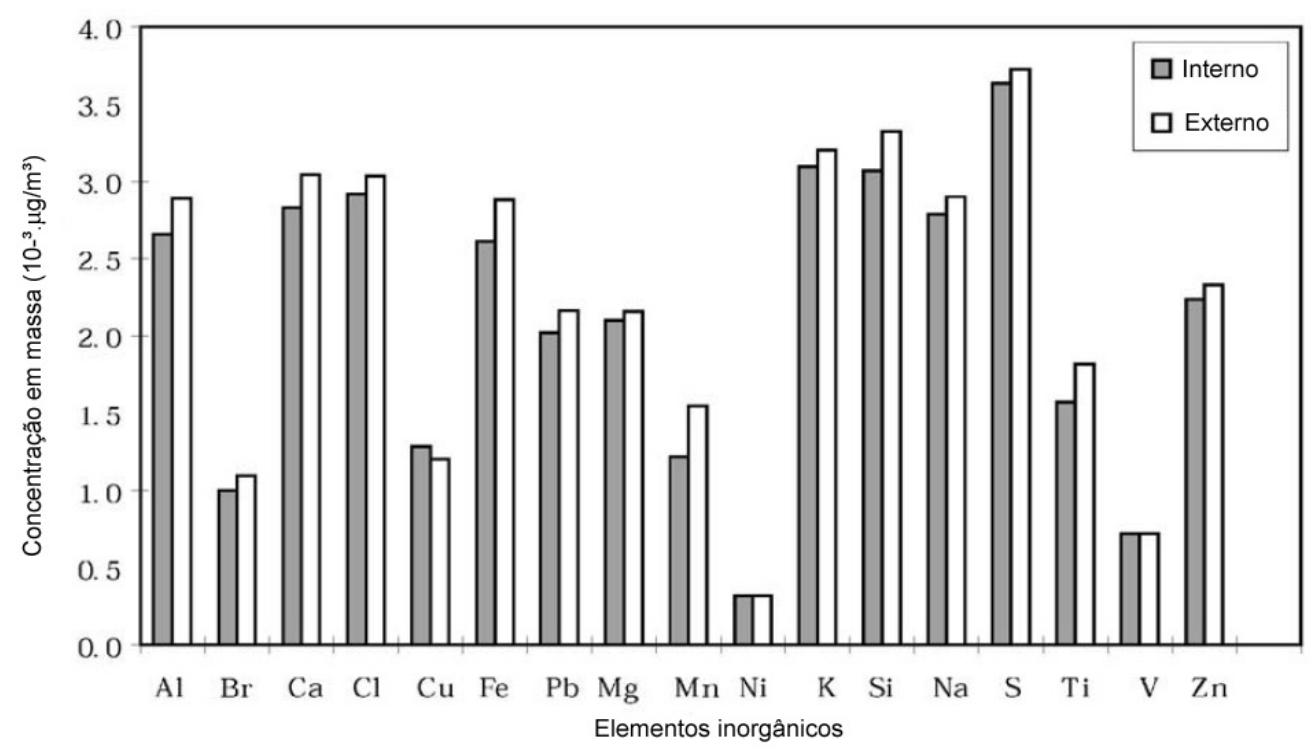

Figura 8 - Concentração em massa para os 17 elementos inorgânicos presentes nos aerodispersóides $\left(\mathrm{MP}_{10}\right)$, em ambientes interno e externo. Fonte: Chao e Wong. (2002).

$\mathrm{Na}$ Figura 8, os autores citados, observaram que as concentrações em massa presentes nos $\mathrm{MP}_{2,5}$ ficaram entre: $3,7 \times 10^{-3} \mu \mathrm{g} / \mathrm{m}^{3}$ e $2,8 \times 10^{-3} \mu \mathrm{g} / \mathrm{m}^{3}$ para o alumínio, o cálcio, o cloro, o ferro, o potássio, o silício, o sódio e o enxofre, $2,7 \times 10^{-3} \mu \mathrm{g} / \mathrm{m}^{3} \mathrm{e}$ $1,6 \times 10^{-3} \mu \mathrm{g} / \mathrm{m}^{3}$ para o chumbo, o magnésio, o titânio e o zinco, $1,5 \times 10^{-3} \mu \mathrm{g} / \mathrm{m}^{3} \mathrm{e}$ $0,4 \times 10^{-3} \mu \mathrm{g} / \mathrm{m}^{3}$ para o bromo, o cobre, o manganês e o vanádio, e menor que $0,3 \times 10^{-3}$ $\mu \mathrm{g} / \mathrm{m}^{3}$ para o níquel.

As doenças pulmonares de origem ocupacional são causadas pela inalação de partículas, névoas, vapores ou gases nocivos nos ambientes internos. O local exato das vias aéreas ou dos pulmões onde a substância inalada irá se depositar e o tipo de doença pulmonar que irá ocorrer dependerão do tamanho e do tipo das partículas inaladas. As partículas grossas (entre $2,5 \mu \mathrm{m}$ e $10 \mu \mathrm{m}$ ) podem ficar retidas nas narinas ou nas grandes vias aéreas, mas as finas (entre $0,1 \mu \mathrm{m}$ e $2,5 \mu \mathrm{m}$ ) atingem os pulmões, conforme Tse et al. (2004). 
A seguir, apresentam-se, na Figura 9, as frações das partículas que podem atingir as vias aéreas superiores, a caixa torácica e a região de troca de gases (alvéolos).

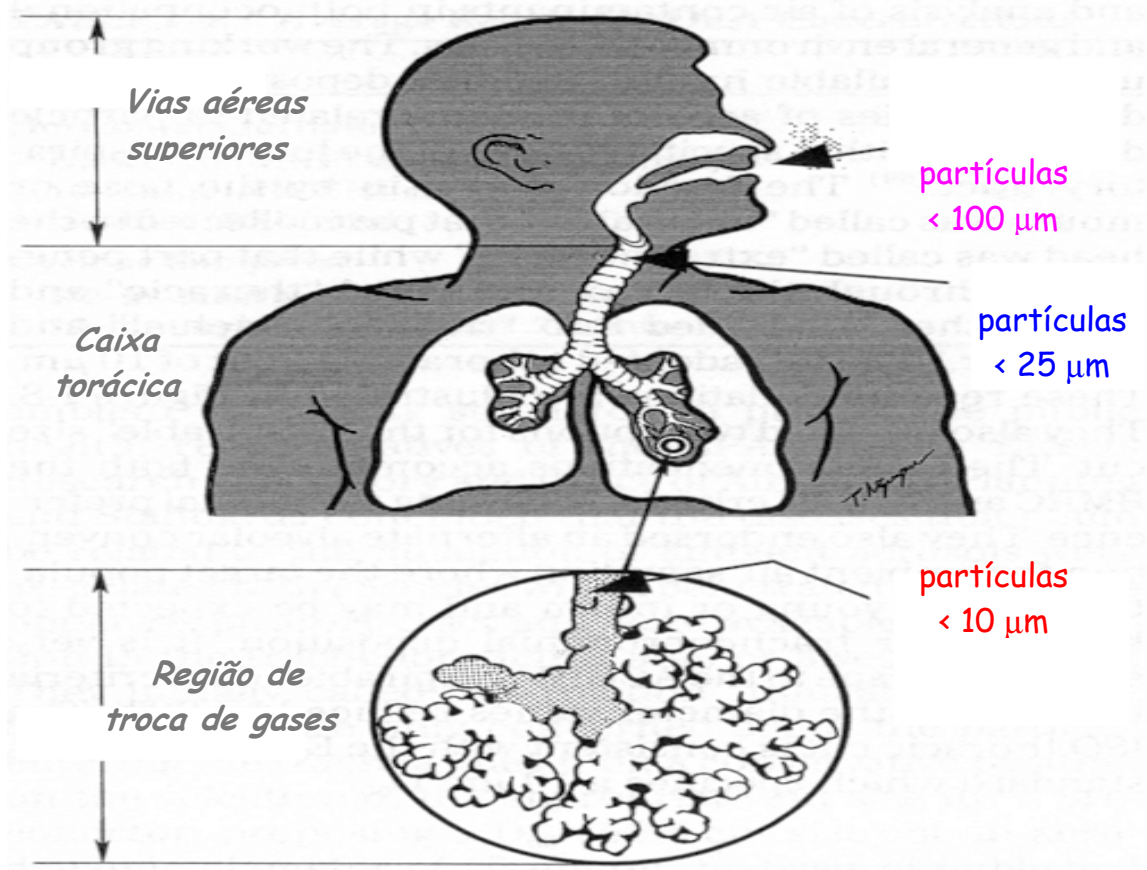

Figura 9 - Classificação dos aerodispersóides quanto ao tamanho e ao local de penetração no pulmão. Fonte: Santos, 2005.

Quando atingem esses órgãos, algumas partículas se dissolvem e podem passar para a corrente sangüínea. A maioria das partículas sólidas que não se dissolvem são removidas pelas defesas do organismo. O corpo possui vários meios para eliminar as partículas aspiradas. Nas vias aéreas, o muco recobre as partículas de modo que a sua expulsão por meio da tosse seja mais fácil.

Nos pulmões, existem células removedoras (denominadas fagócitos) que "engolem" a maioria das partículas, tornando-as inofensivas, conforme Figura 10. Tipos diferentes de partícula produzem reações distintas no organismo. Algumas partículas podem causar reações alérgicas, como a febre do feno ou um tipo de asma. 


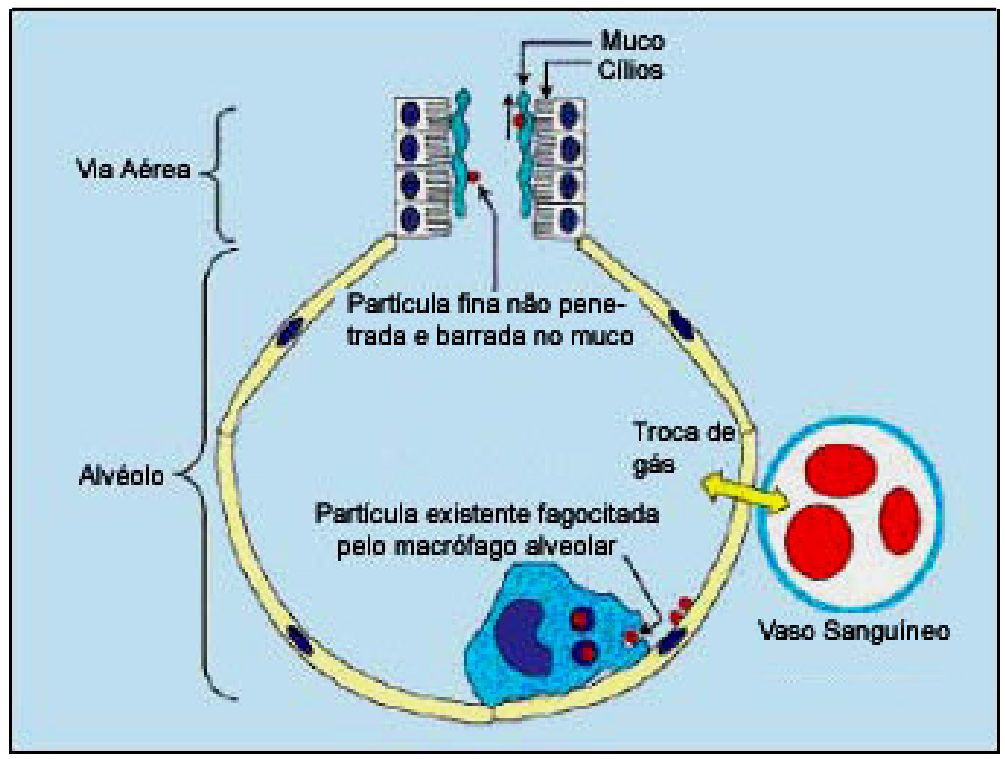

Figura 10 - Detalhe do funcionamento do pulmão para partículas maiores que $1,0 \mu \mathrm{m}$. Fonte: TSI, 2003.

Os alvéolos funcionam como porta de entrada entre as partículas e o organismo, podendo provocar doenças gravíssimas. As partículas menores que 1,0 $\mu \mathrm{m}$ tendem a penetrar nos alvéolos e a chegar ao sangue mais rapidamente, como mostradas na Figura 11.

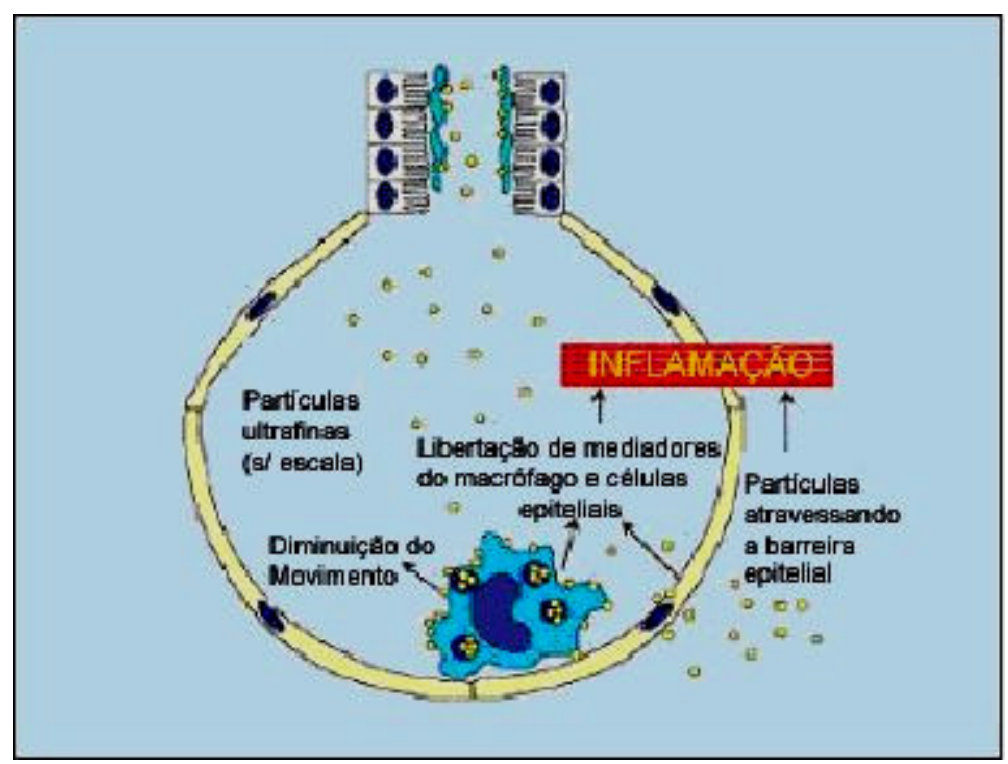

Figura 11 - Detalhe do funcionamento do pulmão para partículas menores que 1,0 $\mu \mathrm{m}$. Fonte: TSI, 2003. 


\subsection{Legislação}

\subsubsection{Ambiente externo}

A Lei Federal n 6.938, de 31 de agosto de 1981, dispõe sobre a Política Nacional do Meio Ambiente no Brasil. Esta lei foi regulamentada em $1^{\circ}$ de junho de 1983 pelo Decreto Federal $\mathrm{n}^{\circ}$ 88.351, que conferiu ao Ministro de Estado do Interior a coordenação geral da política nacional do meio ambiente. Em 15 de março de 1985 foi criado o Ministério de Desenvolvimento Urbano e Meio Ambiente.

O Sistema Nacional do Meio Ambiente (SISNAMA) tem como órgão superior o Conselho Nacional do Meio Ambiente (CONAMA), cujo Regimento inicial foi alterado em 3 de junho de 1985. Cabe ao CONAMA, entre outras atribuições, a seguinte:

- Estabelecer, com o apoio técnico da Secretaria Especial do Meio Ambiente $\left(\mathrm{SEMA}^{2}\right)$, normas e critérios gerais para o licenciamento das atividades efetiva ou potencialmente poluidoras.

- Determinar, quando julgar necessário, antes ou após o respectivo licenciamento, a realização de estudo das alternativas e das possíveis conseqüências ambientais de projetos públicos ou privados de grande porte.

- Estabelecer, com base em estudos da SEMA, normas, critérios e padrões relativos ao controle e à manutenção da qualidade do meio ambiente.

Cabe aos Estados e Municípios a regionalização das medidas emanadas do SISNAMA, elaborando normas e padrões supletivos e complementares.

O órgão estadual do meio ambiente no Estado de São Paulo é a Secretaria do Meio Ambiente (SMA), tendo a CETESB como órgão controlador. A função destes órgãos é determinar, quando necessário, a redução das atividades geradoras de poluição,

\footnotetext{
${ }^{2}$ Atualmente Ministério do Meio Ambiente
} 
mantendo as emissões gasosas ou efluentes líquidos e resíduos sólidos nas condições e limites no licenciamento concedido.

O Decreto citado prevê multas a "quem causar poluição atmosférica que provoque a retirada, ainda que momentânea, dos habitantes de um quarteirão urbano ou localidade equivalente".

A resolução CONAMA n ${ }^{\circ} 3$ de 28 de Junho de 1990 fixou padrões de qualidade do ar externo para Partículas Totais em Suspensão, Fumaça, Partículas Inaláveis, Dióxido de Enxofre, Monóxido de Carbono, Dióxido de Nitrogênio e Ozônio. Nesta resolução, os padrões primários de qualidade do ar definidos como sendo as concentrações de poluente que, se ultrapassadas, poderão afetar a saúde da população e o mínimo efeito ao meio ambiente. Estes padrões poderiam ser extrapolados para interiores, pois se considera inclusive a exposição continuada de pessoas sensíveis, como crianças e idosos, porém o escopo desta resolução é para poluentes da atmosfera externa.

\subsubsection{Ambiente interno}

A Lei 8.078 de 11 de setembro de 1990, art. 6 ${ }^{\circ}$ do Código de Defesa do Consumidor, estabelece que são direitos básicos do consumidor a proteção da vida, da saúde e da segurança contra os riscos provocados pelo fornecimento de produtos e serviços perigosos ou nocivos. No art. 12 do mesmo código, determina-se que o construtor, nacional ou estrangeiro, responde, independentemente da existência de culpa, pela reparação dos danos causados aos consumidores por defeitos decorrentes de projeto, construção e montagem, bem como por informações insuficientes ou inadequadas sobre sua utilização e riscos. Assim como, no art. 56 as infrações das normas de defesa do consumidor ficam sujeitas, conforme o caso, à multa, à inutilização do produto, à cassação do registro do produto junto ao órgão competente, à detenção de seis meses a dois anos, entre outras. 
O MS, para sanar a falta de legislação referente à poluição do ar de interiores, publicou a portaria $\mathrm{n}^{\circ} 3523$ de 28 de agosto de 1998, mostrada no Anexo B, referente à qualidade do ar de interiores climatizados, definindo, no art. $2^{\circ}$, que seria confeccionado um Regulamento Técnico, o qual estabeleceria padrões de qualidade do ar interno para ambientes climatizados.

Esta portaria define o que é Síndrome dos Edifícios Doentes, como sendo o surgimento de sintomas comuns à população em geral, mas que em uma situação temporal, pode ser relacionado a um edifício em particular. A portaria aplica-se ainda aos ambientes climatizados de uso coletivo já existentes e aqueles a serem executados, de forma complementar, aos regidos por normas específicas. Para os ambientes climatizados com exigência de filtros absolutos ou instalações especiais, tais como aquelas que atendem a processos produtivos, instalações hospitalares e outros, aplicam-se as normas e regulamento específicos, sem prejuízo do disposto desta portaria, no que couber.

Os proprietários, locatários e prepostos, responsáveis por sistemas de climatização com capacidade acima de 5 TR $(15.000 \mathrm{kcal} / \mathrm{h}=60.000 \mathrm{BTU} / \mathrm{h})$, deverão manter um responsável técnico habilitado, com as seguintes atribuições:

1. Implantar e manter disponível no imóvel um Plano de Manutenção, Operação e Controle (PMOC), adotado para o sistema de climatização.

2. Garantir a aplicação do PMOC.

3. Manter disponível o registro da execução dos procedimentos estabelecidos no PMOC.

4. Divulgar os procedimentos e resultados das atividades de manutenção, operação e controle aos ocupantes.

O não cumprimento desta portaria configura infração sanitária, sujeitando o proprietário ou o locatário do imóvel ou o preposto, bem como o responsável técnico, quando exigido, às penalidades previstas na Lei n ${ }^{\circ}$ 6.437, de 20 de agosto de 1977, sem prejuízo de outras penalidades previstas em legislação específica. 
A Agência Nacional de Vigilância Sanitária (ANVISA), definida pela Lei $n^{\circ}$ 9782, de 26 de janeiro de 1999, tem por finalidade regulamentar, controlar e fiscalizar os produtos e serviços que envolvam riscos à saúde da população. Os produtos e serviços são submetidos ao controle da vigilância sanitária (Vigilâncias Sanitárias Estaduais e Municipais e ANVISA) inclusive dos ambientes, dos insumos e das tecnologias a eles relacionadas.

Em 24 de outubro de 2000, conforme previsto na portaria $n^{\circ} 3523$, o Ministério da Saúde, por meio da ANVISA, publicou a resolução $\mathrm{n}^{\circ} 176$, a qual contou com a colaboração de associações, institutos, faculdades, fundações, além do Ministério do Meio Ambiente e da Organização Pan-Americana de Saúde (OPAS). A resolução ${ }^{\circ}$ 176 foi revisada e atualizada com dados adquiridos em dois anos de experiência e publicou no Diário Oficial da União em 20 de Janeiro de 2003 a resolução ${ }^{\circ} 9$ (RE $\mathrm{n}^{\circ}$ ), de 16 de Janeiro de 2003, mostrada no Anexo A.

Esta resolução compreende orientações técnicas sobre Padrões Referenciais de Qualidade do Ar Interior em ambientes climatizados artificialmente, de uso público e coletivo, valores máximos recomendáveis para contaminação biológica, química e parâmetros físicos do ar interno, tendo o limite da concentração de aerodispersóides totais de $80 \mu \mathrm{g} / \mathrm{m}^{3}$. A resolução prevê ainda métodos analíticos e recomendações para controle e correção, caso os padrões de ar forem considerados regulares ou ruins.

Quanto à identificação das fontes poluição, foram definidas quatro Normas Técnicas:

- NT 001 - Método de amostragem e análise de bioaerosol em ambientes interiores.

- NT 002 - Método de amostragem e análise da concentração de dióxido de carbono em ambientes interiores.

- NT 003 - Método de amostragem. Determinação de temperatura, umidade e velocidade do ar em ambientes interiores. 
- NT 004 - Método de amostragem e análise de concentração de aerodispersóides em ambientes interiores.

\subsubsection{Padrões de concentração em massa}

Na tabela 5, identificam-se valores de referência para a concentração em massa de $\mathrm{PM}_{10}$ em diferentes países e organizações.

Tabela 5 - Valores de referência para concentração em massa de $\mathbf{P M}_{10}$. Fontes: Tse et al (2004) e CETESB (2004).

\begin{tabular}{|c|c|}
\hline Países e organizações & Valores de referência \\
\hline \multicolumn{2}{|l|}{ Hong Kong } \\
\hline \multirow[t]{2}{*}{ EPD HK (ambiente externo) } & $55 \mu \mathrm{g} / \mathrm{m}^{3}$ (anual) \\
\hline & $180 \mu \mathrm{g} / \mathrm{m}^{3}$ (8 horas) \\
\hline \multirow[t]{2}{*}{ GN (ambiente interno, 8 horas) } & $20 \mu \mathrm{g} / \mathrm{m}^{3}$ (nível 1) \\
\hline & $180 \mu \mathrm{g} / \mathrm{m}^{3}$ (nível 2) \\
\hline \multicolumn{2}{|l|}{ Singapura } \\
\hline \multirow[t]{2}{*}{ Ministério do Meio Ambiente (ambiente externo) } & $50 \mu \mathrm{g} / \mathrm{m}^{3}$ (anual) \\
\hline & $150 \mu \mathrm{g} / \mathrm{m}^{3}$ (24 horas) \\
\hline \multicolumn{2}{|l|}{ Tailândia } \\
\hline \multirow[t]{2}{*}{ (ambiente externo) } & $50 \mu \mathrm{g} / \mathrm{m}^{3}$ (anual) \\
\hline & $120 \mu \mathrm{g} / \mathrm{m}^{3}$ (24 horas) \\
\hline \multicolumn{2}{|l|}{ Inglaterra } \\
\hline \multirow[t]{2}{*}{ (ambiente externo) } & $\begin{array}{l}50 \mu \mathrm{g} / \mathrm{m}^{3} \text { ( } 24 \text { horas), não exceder mais do que } 35 \\
\text { vezes por ano }\end{array}$ \\
\hline & $40 \mu \mathrm{g} / \mathrm{m}^{3}$ (anual) \\
\hline \multicolumn{2}{|l|}{$U S A$} \\
\hline \multirow[t]{2}{*}{ EPA (ambiente externo) } & $50 \mu \mathrm{g} / \mathrm{m}^{3}$ (anual) \\
\hline & $150 \mu \mathrm{g} / \mathrm{m}^{3}$ (24 horas) \\
\hline \multicolumn{2}{|l|}{ Brasil } \\
\hline \multirow[t]{2}{*}{ CETESB (ambiente externo) } & $50 \mu \mathrm{g} / \mathrm{m}^{3}$ (anual) \\
\hline & $150 \mu \mathrm{g} / \mathrm{m}^{3}$ (24 horas) \\
\hline ANVISA (ambiente interno) & $80 \mu \mathrm{g} / \mathrm{m}^{3}$ \\
\hline
\end{tabular}




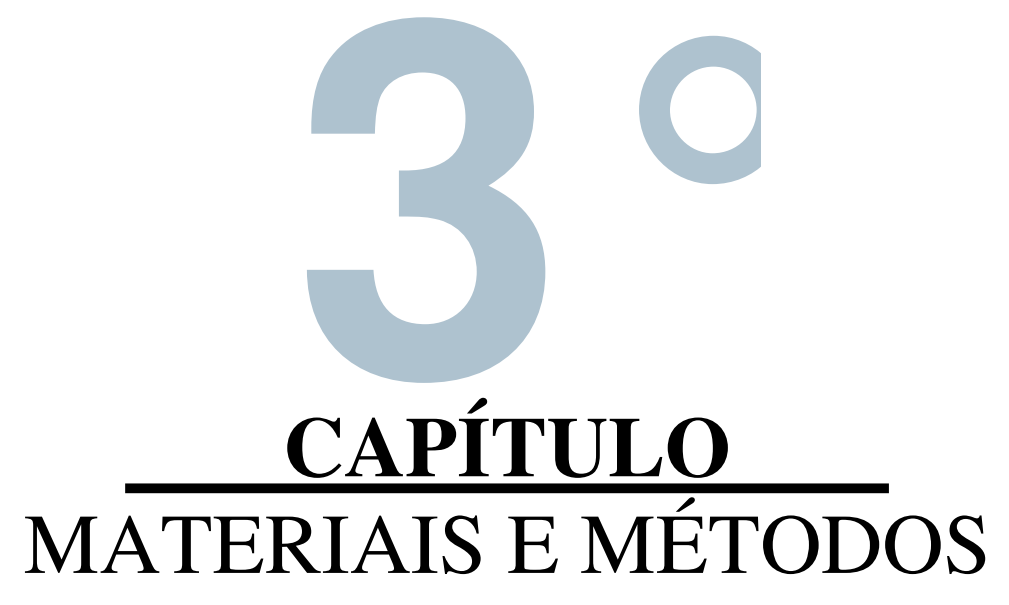




\section{MATERIAIS E MÉTODOS}

\subsection{Revisão dos Métodos de Amostragem para Aerodispersóides}

$\mathrm{Na}$ seqüência, são descritos os principais métodos de amostragem para aerodispersóides em ambientes internos, citados por Cohn (2003). Estes métodos podem ser empregados para avaliar a concentração em massa ou em número de partículas suspensas no ar. Em razão dos objetivos definidos para a amostragem, podem ser utilizados desde métodos mais simples, por exemplo, medidas de massa total em suspensão e fumaça preta, até métodos mais sofisticados, por exemplo, a coleta de partículas por fração de tamanho para subseqüente caracterização física e química.

\subsubsection{Métodos de amostragem da concentração em massa}

\subsubsection{Método do amostrador de grande volume por gravimetria}

O método do amostrador de grande volume funciona por meio de sucção do ar através de um filtro, sendo o filtro, geralmente, composto por fibra de vidro ou outro material relativamente inerte, não higroscópico e que apresente baixa resistência à passagem de ar. As dimensões do orifício de entrada do amostrador (porta filtro) medem cerca de 25 x $30 \mathrm{~cm}$. As dimensões do filtro são de 20,3 x 25,4 cm. O cálculo da massa de aerodispersóide coletado é determinado por gravimetria. A massa é obtida em uma balança eletrônica analítica, com sensibilidade de $0,1 \mathrm{mg}$. A taxa de fluxo de ar succionado é de $1,1 \mathrm{~m}^{3} / \mathrm{min}$ a $1,7 \mathrm{~m}^{3} / \mathrm{min}\left(\approx 2000 \mathrm{~m}^{3} /\right.$ dia $)$. O dispositivo indicador de fluxo de ar é calibrado utilizando-se um calibrador padrão de vazão (CPV).

O filtro é pesado antes e depois da amostragem em uma balança sob condições especiais de temperatura e umidade, com intuito de determinar a massa líquida do material particulado coletado. Antes de cada pesagem, o filtro é pré-condicionado 
por pelo menos 24 horas em dessecadores. A concentração em massa de aerodispersóide é calculada pelo quociente entre a massa de particulado e o volume total de ar amostrado. O sistema gravimétrico manual é muito trabalhoso.

O método se aplica para medições de concentração em massa de aerodispersóide com tempo de coleta de 24 horas, com níveis acima de $1-5 \mu \mathrm{g} / \mathrm{m}^{3}$ e partículas com tamanho entre 0,3 e $100 \mu \mathrm{m}$.

\subsubsection{Método do amostrador por radiometria / Atenuação $\beta$}

Na medição de aerodispersóide com amostrador por atenuação da radiação $\beta$, um fluxo de ar é succionado isocineticamente através de um conduto no interior do equipamento de medição. O aerodispersóide contido nesse fluxo de ar é depositado sobre um filtro de papel em forma de fita, sendo em seguida bombardeado por uma fonte de radiação $\beta$. A atenuação dos raios- $\beta$ devido à massa de particulado existente no filtro é utilizada como uma medida indireta de concentração de massa. Após um período pré-determinado, a fita é deslocada automaticamente e uma nova massa de material particulado é coletada. A concentração de aerodispersóide é determinada pelo valor máximo de armazenamento do equipamento.

Os equipamentos de medição baseados nesse princípio são controlados por microprocessadores e denominados de monitores de atenuação de partículas-beta. A absorção- $\beta$ por unidade de massa depende da razão entre o número e a massa atômica dos elementos presentes na amostra. Esta razão varia entre 0,44 e 0,53 para todos os elementos (exceto $\mathrm{H}_{2}$ e $\mathrm{Pb}$ ).

\subsubsection{Método do amostrador por refletância / Black Smoke}

A determinação da concentração de aerodispersóide pelo amostrador por refletância é obtida pela análise do escurecimento (opacidade) de um filtro carregado de 
partículas, que é interpretada como uma medição do carbono grafítico total contido nos sistemas de aerodispersóides do ambiente.

A análise do escurecimento é determinada pela comparação da refletância da luz de um filtro não carregado $\left(R_{0}\right)$ e de um filtro carregado $(R)$. A luz refletida passa duas vezes pela camada de partículas depositadas no filtro, ou seja: $\operatorname{Ln}\left(R / R_{0}\right)=2 \mathrm{Ln}$ $\left(I / I_{0}\right)$, onde $I_{0}$ é a intensidade de luz incidente e $I$ é a intensidade de luz transmitida através da camada de partículas na ausência hipotética do filtro.

$\mathrm{Na}$ prática, as partículas penetram até certo ponto, dependendo do tipo de filtro e velocidade do fluxo de ar. Isso produz um aumento da reflexão e um decrécimo da transmissão.

\subsubsection{Método do amostrador por nefelometria / espalhamento de luz}

A determinação da concentração de aerodispersóide se dá por meio da análise do feixe de luz espalhado, sendo a quantidade de luz espalhada uma função do número e do tamanho das partículas no volume de ar medido. Quando um feixe de luz atravessa um determinado volume de ar carregado de aerodispersóides, esse feixe de luz incidente é simultaneamente atenuado e espalhado por essas partículas.

O fenômeno de espalhamento de luz é determinado pela não absorbância das partículas do ambiente, especialmente dos aerodispersóides secundários (sulfatos + amônia + nitratos). A conversão dos valores obtidos do espalhamento de luz para valores de concentração em massa se realiza da mesma forma que na técnica de refletância.

A técnica de espalhamento de luz é aplicada quando se deseja medir aerodispersóides entre 0,1 e $10 \mu \mathrm{m}$. 


\subsubsection{Métodos de amostragem da concentração em número de partículas}

\subsubsection{Método de amostragem para contador ótico}

O método de amostragem para contador ótico se dá pela passagem do ar através de uma membrana filtrante, utilizando-se vácuo. O fluxo é controlado por um orifício limitante ou por um fluxômetro, assim, o volume total de ar amostrado é determinado pelo tempo de amostragem. A membrana filtrante é em seguida examinada microscopicamente para determinar o número de partículas coletadas na amostra de ar.

A precisão e a exatidão deste método estão sujeitas aos erros humanos e mecânicos. Para reduzir o erro humano, os técnicos devem ser treinados em microscopia e em medição e contagem de partículas. Técnicos experientes têm mais chances de detectar deficiência no equipamento, reduzindo assim a possibilidade de erro. Amostras-padrão podem ser obtidas ou preparadas para uso em treinamento dos técnicos na contagem e medição de aerodispersóide.

A técnica de amostragem para contador ótico é aplicada quando se deseja medir aerodispersóides maiores que $5 \mu \mathrm{m}$.

\subsubsection{Método de amostragem para contador de núcleo de condensação}

Os elementos que constituem o sistema de contador de núcleo de condensação são: uma sonda amostradora com bordas internas afiadas, um tubo de passagem de ar, uma câmara de detecção e medição de aerodispersóide, um sistema de medição ou controle do fluxo de ar e um sistema de exaustão do ar. O dispositivo de indução de fluxo de ar pode ser uma bomba de vácuo. Para atingir a característica de corte necessária à verificação do ar, pode-se colocar um dispositivo de corte de tamanho, na entrada da sonda. 
O equipamento emprega a condensação das partículas, por meio do vapor de álcool. Esta condensação tem a função de aumentar o tamanho dos aerodispersóides, para serem contados pela câmara de detecção.

O método de amostragem para contador de núcleo de condensação mede a concentração em número de aerodispersóide entre 1 e $0,02 \mu \mathrm{m}$.

\subsection{Equipamentos utilizados na pesquisa}

Para a seleção ou escolha dos equipamentos, foi considerado o menor diâmetro detectável das partículas, pois as Partículas Suspensas Respiráveis (PSR) são 70-80\% formadas por partículas menores que $2 \mu \mathrm{m}$, de acordo com estudos de Zheng et al. (2000). Desse modo, os equipamentos deveriam detectar principalmente partículas finas e ultrafinas.

Os equipamentos além de medir a concentração de aerodispersóides nos vários tamanhos, deveriam também atender as seguintes características:

- Dimensões reduzidas, facilitando o seu transporte.

- Fonte de energia própria, funcionando com autonomia.

- Medições contínuas, estabelecendo relações com o tempo.

- Data logging, armazenando os dados.

\subsubsection{Monitor Dust-Trak para aerossóis (modelo 8520)}

Um dos equipamentos adquiridos pela Universidade de São Paulo, em junho de 2005, para o LabESPUSP, foi o Dust Trak Aerosol Monitor (modelo 8520), fabricado pela empresa Thermo-Systems Incorporated - TSI. Este equipamento mede a concentração em massa de aerodispersóides finos e grossos, entre 0,1 e $10 \mu \mathrm{m}$, além de atender todas as exigências desta pesquisa. 
O monitor de aerodispersóides mencionado utiliza o método de amostragem por nefelometria ou espalhamento de luz. Para este método, o equipamento mede a concentração em massa de aerodispersóide por amostras de ar e pela análise do feixe de luz espalhado em função do número e do tamanho das partículas no volume de ar medido. A conversão dos valores obtidos do espalhamento de luz para valores de concentração em massa se realiza pela comparação da refletância da luz de uma amostra de ar não carregada com aerodispersóide $\left(R_{0}\right)$ e de uma amostra carregada $(R)$. A luz refletida passa duas vezes pela camada das partículas, ou seja: $\operatorname{Ln}\left(R / R_{0}\right)=$ $2 \operatorname{Ln}\left(I / I_{0}\right)$, onde $I_{0}$ é a intensidade de luz incidente e $I$ é a intensidade de luz transmitida através da camada de partículas, resultando em massa por volume de ar medido $\left(\mu \mathrm{g} / \mathrm{m}^{3}\right)$.

A seguir, na Figura 12, apresenta-se uma comparação entre o método de espalhamento de luz (Dust Trak) e o método de amostragem de grande volume por gravimetria (Hi-Vol Sampler), segundo Guo et al. (2004).

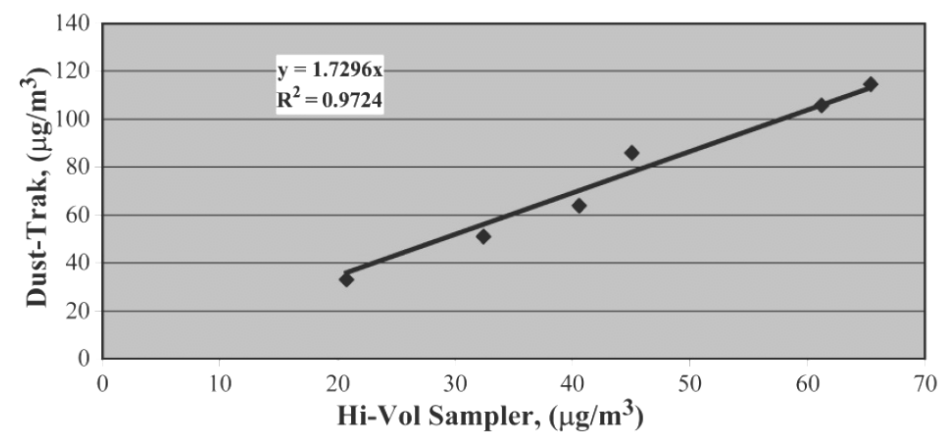

Figura 12 - Comparação entre o método de espalhamento de luz (Dust-Trak) e de amostrador de grande volume (Hi-Vol Sampler). Fonte: Guo et al. (2004)

Segundo os autores citados, o método de espalhamento de luz apresenta alta correlação com o método de amostragem de grande volume por gravimetria. O coeficiente $\mathrm{R}^{2}$ é maior que 0,97 . A calibração indicou que a concentração em massa, obtida pelo monitor Dust Trak, se aproxima daquela obtida pelo amostrador de grande volume. 
Os principais componentes do equipamento Dust Track Aerosol Monitor, bem como a validação do método de medição, a calibragem dos equipamentos, entre outras informações, são apresentados no Anexo C.

\subsubsection{Contador de partículas ultrafinas P-Trak (modelo 8525)}

Um outro equipamento adquirido pela Universidade de São Paulo, para o LabESPUSP, foi o P-Trak Ultrafine Particle Counter (modelo 8525), fabricado pela mesma empresa TSI Inc. Este equipamento mede a concentração em número de aerodispersóides finos e ultrafinos, entre 0,02 e $1 \mu \mathrm{m}$, além de atender todas as exigências desta pesquisa.

O contador de partículas utilizado mede a concentração em número de aerodispersóides pelo método de amostragem de contador por núcleo de condensação. Para este método o equipamento emprega a condensação das partículas, por meio do vapor de álcool. A condensação tem a função de aumentar o tamanho das partículas, para serem contadas pela câmara de detecção. A conversão para concentração em número de partículas por volume de ar medido (partículas $/ \mathrm{cm}^{3}$ ) é realizada da mesma forma que na técnica de espalhamento de luz, conforme equipamento anterior.

Os principais componentes do equipamento P-Trak Ultrafine Particle Counter, bem como a validação do método de medição, entre outras informações, são apresentados no Anexo C.

\subsection{Metodologia da Pesquisa}

O plano de desenvolvimento desta pesquisa foi dividido em duas fases. Em primeiro lugar foram avaliadas a concentração de aerodispersóides, temperatura, umidade relativa e características dos ambientes internos em edifícios residenciais e 
comerciais localizados na Região Metropolitana de São Paulo (RMSP). Em seguida fizeram-se as mesmas medições para cinco ambientes internos em um apartamento localizado no Município de São Caetano do Sul, com o detalhamento das fontes.

\subsubsection{Região de estudo}

As medições no âmbito da qualidade do ar interno foram realizadas na RMSP, que ocupa a Região Sudeste do Brasil, a $23^{\circ} \mathrm{S}$ e $46^{\circ} \mathrm{W}$. De acordo com a CETESB (2004), a RMSP possui uma área de $8.051 \mathrm{~km}^{2}$, com uma população superior a 17 milhões de habitantes, distribuída em uma área urbanizada e de maneira desordenada em $1.747 \mathrm{~km}^{2}$ dessa área. A RMSP corresponde cerca de $0,1 \%$ do território brasileiro e é o terceiro maior conglomerado do mundo, responsável por 1/6 do PIB nacional.

Segundo a CETESB (2004), a região sofre com a deterioração da qualidade do ar, devida às emissões atmosféricas de cerca de 2.000 indústrias de alto potencial poluidor e por uma frota de aproximadamente 7,8 milhões de veículos. Ainda de acordo com as estimativas de 2004, essas fontes são responsáveis pelas emissões dos seguintes poluentes na atmosférica: 1,7 milhões de t/ano de monóxido de carbono (CO), 404 mil t/ano de hidrocarbonetos (HC), 371 mil t/ano de óxidos de nitrogênios $\left(\mathrm{NO}_{\mathrm{x}}\right), 63$ mil t/ano de material particulado total (MP) e 36 mil t/ano de óxido de enxofre $\left(\mathrm{SO}_{\mathrm{x}}\right)$. Desses totais, os veículos são responsáveis por $98 \%$ das emissões de $\mathrm{CO}, 97 \%$ de $\mathrm{HC}, 96 \%$ de $\mathrm{NO}_{\mathrm{x}}, 50 \%$ de $\mathrm{MP}$ e $55 \%$ de $\mathrm{SO}_{\mathrm{x}}$.

O clima da RMSP pode ser dividido em duas estações predominantes: uma estação chuvosa, que compreende o período de outubro a abril, e outra estação seca que vai de maio a setembro. Durante o período chuvoso, as condições de dispersão dos poluentes emitidos na atmosférica são favoráveis. No período seco, as condições de dispersão são desfavoráveis, devido à formação dos anticiclones (sistemas de altas pressões) subtropical e polar, influenciados pela inversão térmica. 
Além das características gerais observadas nas duas estações, a RMSP apresenta ainda o processo de formação de ilha de calor. Este processo pode provocar algumas mudanças no clima da região, tais como a diminuição de nevoeiros no centro da cidade e diminuição da garoa típica que ocorria na região.

As normais climatológicas de 30 anos (1961-1990) do município de São Paulo, de acordo com o Instituto Nacional de Meteorologia (INMET), igualmente apresentadas no relatório da CETESB (2004), foram de: $19,3^{\circ} \mathrm{C}$ para a temperatura média, 1.455 mm para a precipitação total, $78 \%$ para a umidade relativa media, 1.733 horas e décimos para a insolação total, e 7,2 para a nebulosidade média.

Observa-se, na Figura 13, a distribuição mensal do número de ultrapassagens do padrão e do nível de atenção para aerodispersóides menores que $10 \mu \mathrm{m}$ na RMSP. Conforme a CETESB (2004), o maior número de ultrapassagens ocorre preferencialmente nos meses de inverno, com ocorrência de nível de atenção no mês de agosto.

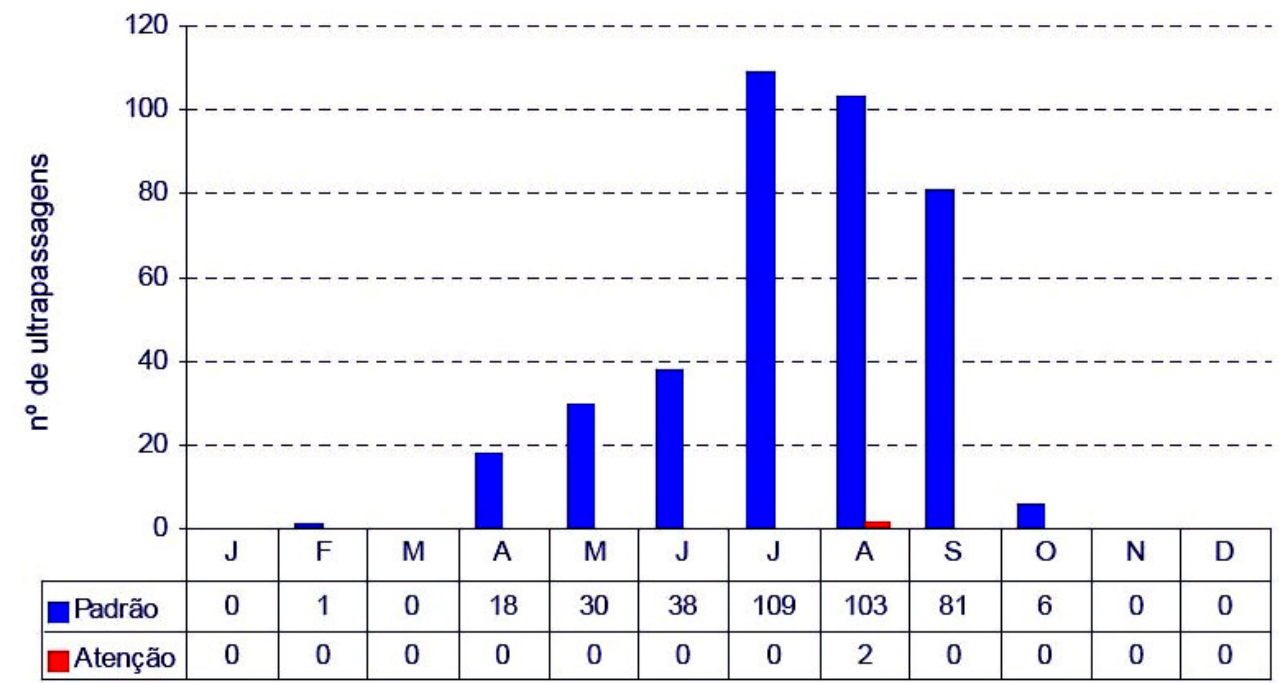

Figura 13 - Número de ultrapassagens do padrão e do nível de atenção para aerodispersóides menores que $10 \mu \mathrm{m}$, por mês (1997 à 2004) na RMSP. Fonte: CETESB, 2004. 
Quanto à localização, as medições ocorreram em edifícios residenciais e comerciais nas cidades de Santo André, São Caetano do Sul, São Bernardo do Campo e São Paulo, entre julho de 2005 e janeiro de 2006. Os locais foram escolhidos de acordo com os sistemas prediais existentes, a fim de diversificar as amostras.

Os ambientes selecionados foram agrupados em edifícios com sistema de ventilação natural e com sistema de condicionamento de ar, exceto para a clínica médica que apresentou sistema de ventilação natural, como mostrado na Tabela 6.

Tabela 6 - Características e localização dos edifícios analisados.

\begin{tabular}{lll}
\hline Municípios/ Categorias & Residencial (Ventilação Natural) & Comercial (Condicionamento de Ar) \\
\hline Santo André & - & Loja de Supermercado (V. Homero Thon) \\
\hline São Bernardo do Campo & Residência 1 (J. M. Adelaide) & Clínica Médica 1* (V. Euclides) \\
& Residência 2 (J. M. Adelaide) & Clínica Médica 2* (V. Euclides) \\
\hline São Caetano do Sul & Apartamento 1 (S. Paula) & - \\
& Apartamento 2 (S. Paula) & \\
\hline São Paulo & Residência 3 (Campo Belo) & Escritório 1 (Pinheiros) \\
& Residência 4 (V. Bela) & Escritório 2 (Pinheiros) \\
& Apartamento 3 (Butantã) & Escritório 3 (Pinheiros) \\
& Apartamento 4 (Butantã) & Escritório 4 (Sumaré) \\
& Apartamento 5 (Butantã) & Escritório 5 (Sumaré) \\
& Apartamento 6 (V. Mariana) & Sala de Aula 1 (Butantã) \\
& & Sala de Aula 2 (V. Mariana) \\
& Sala de Laboratório 1 (Butantã) \\
& Sala de Laboratório 2 (Butantã) \\
\hline
\end{tabular}

*entilação natural

\subsubsection{Procedimentos de medição}

Os pontos de medição, segundo NBR 13.700/1996, podem ser reduzidos significativamente usando o plano de amostragem sequiencial. $\mathrm{Na}$ amostragem seqüencial, a concentração em massa ou em número de aerodispersóides é comparada a cada instante com o valor de referência normalizado para a concentração limite, o qual será função da quantidade de amostragem realizada. 
Segundo a NT 004 - Método de Amostragem e Análise de Concentração de Aerodispersóides em Ambientes Interiores (ANVISA, 2003), mostrada no Anexo A, a quantidade de pontos de medição pode ser igual a um, para os primeiros mil metros quadrados de área construída.

Nesta pesquisa e durante as duas fases, foram realizadas as medições em um ponto a cada ambiente analisado, alterando o período de amostragem em horas, dependendo do tipo de equipamento utilizado e da necessidade de pesquisar um ambiente com mais detalhe, conforme será explicado adiante. Quanto ao intervalo seqüencial, os equipamentos foram programados para coletar a concentração de aerodispersóides a cada minuto.

\subsubsection{Programa experimental de campo $\left(1^{\mathrm{a}}\right.$ fase $)$}

A metodologia foi medir a concentração em massa e em número para um ponto com amostragem seqüencial em edifícios residenciais e comerciais localizados na RMSP, bem como coletar a temperatura, a umidade relativa e as características destes ambientes. As temperaturas e as umidades relativas internas foram medidas por meio de leitura direta.

Para as temperaturas e umidades relativas internas, os dados foram obtidos no início e no fim de cada medição. Os dados de concentração, apesar de serem coletados em amostragens sequienciais a cada minuto, foram obtidos durante vinte e quatro horas, para o Dust Trak Aerosol Monitor e até oito horas, para o P-Trak Ultrafine Particle Counter.

As características observadas em cada ambiente foram: aberturas de portas e de janelas, presença de fumaça e móveis de madeira ou compensado. Se por algum motivo, estas características ocorressem durante as medições, então eram observadas e anotadas no final de cada amostragem. 
A quantidade de pontos de medição foi reduzida a um em cada edifício residencial ou comercial analisado, igualmente mencionado. O ponto de medição apresentou as mesmas características em todas as medições, ou seja, os equipamentos foram localizados no centro do ambiente e as atividades dos usuários ocorreram no período diurno.

Em cada ponto medido, observou-se a existência ou não de ar-condicionado. Para esta característica, todos os edifícios residenciais apresentaram ventilação natural e todos os edifícios comerciais apresentaram condicionamento de ar, exceto as clínicas médicas com ventilação natural.

\subsubsection{Programa experimental de campo ( $2^{\mathrm{a}}$ fase $)$}

A metodologia foi medir a concentração, a temperatura e a umidade relativa, associando-se aos eventos de pintura, reforma, limpeza, cozimento, entre outros, através das variáveis medidas e do controle das aberturas, porta e janela. As medições foram realizadas a cada minuto, durante vinte e quatro horas, e os valores de temperatura e de umidade foram obtidos a cada hora. Os ambientes medidos foram a cozinha, área de serviço, sala de estar, dormitório e banheiro. A rotina desse ensaio foi repetida somente na cozinha, na sala de estar e no banheiro, a fim de confirmar algumas suspeitas.

O ensaio foi realizado em um apartamento no Município de São Caetano do Sul, na RMSP. Os ambientes medidos foram selecionados de acordo com as fontes internas de poluição de aerodispersóides, dentre elas: o cozimento, a limpeza, a reforma, além de outras atividades realizadas pelos usuários durante as medições. O objetivo desta fase foi detalhar as fontes por meio das concentrações e das atividades domésticas ocupacionais observadas. Cabe salientar, que não foi notada a presença de fumaça de cigarro nos sete dias analisados. 
Quanto à caracterização do edifício, o mesmo foi construído em concreto armado, contendo janelas de alumínio, portas de madeira, pisos e azulejos de cerâmica, exceto no hall de entrada e social com piso de granito. As obras do edifício foram finalizadas em 1988, tendo aspecto geral conservado. O apartamento analisado foi pintado em julho de 2005. O edifício apresenta 15 andares, com dois apartamentos a cada andares, sendo o apartamento no $12^{\circ}$ andar.

Antes do evento, as portas e as janelas foram fechadas para o total controle das características internas, porém durante as medições as mesmas foram abertas. Durante os eventos, foram obtidas as concentrações de aerodispersóides, temperatura, umidade relativa, aberturas de portas e janelas, além de um croqui do ambiente interno, posicionando os equipamentos e os móveis.

Os equipamentos utilizados na pesquisa permaneceram ligados entre $0 \mathrm{~h} 00$ e $23 \mathrm{~h} 30 \mathrm{e}$ desligados durante trinta minutos entre $23 \mathrm{~h} 30$ e $0 \mathrm{~h} 00$. Para o equipamento P-Trak Ultrafine Particle Counter, durante este período de medição, a cápsula para o álcool, que faz a condensação das partículas, foi abastecida a cada oito horas, durante um intervalo de vinte minutos, com o equipamento desligado. $\mathrm{O}$ intervalo de trinta minutos, que os equipamentos estavam desligados, ocorreram os seguintes procedimentos: calibragem, obtenção dos dados, programação das novas medições e abastecimento da cápsula para o álcool. Os valores obtidos pelos equipamentos foram automaticamente gravados no próprio equipamento por meio de data logger.

Nos próximos itens, apresentam-se os procedimentos realizados nos ambientes do apartamento:

\subsection{Cozinha}

A medição na cozinha foi realizada nos dias 12 e 17 de janeiro de 2006, tendo início à 0 h00 e término às $23 \mathrm{~h} 30$. Antes da medição, as janelas e as portas foram fechadas, 
minimizando as trocas de ar externo. Para localizar as portas, as janelas, a mobília e os equipamentos apresenta-se , na Figura 14, o croqui da cozinha.

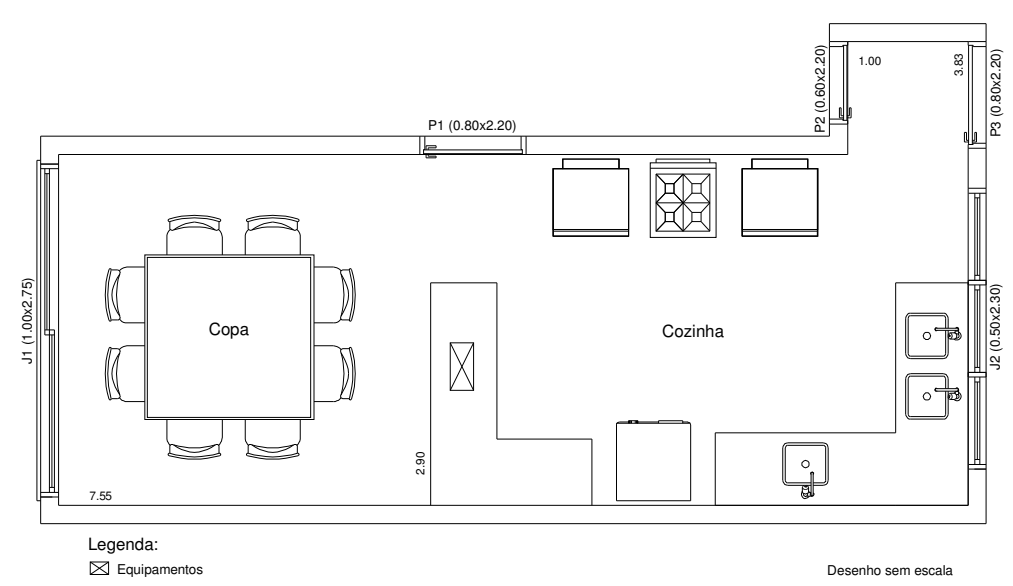

Figura 14 - Croqui da cozinha, com o posicionamento das portas, das janelas, da mobília e dos equipamentos.

No dia 12 de janeiro de 2006, não houve atividade dos usuários entre 0h00 e 8h00. Entre $8 \mathrm{~h} 01$ e 9h00, eles estavam preparando e tomando café da manhã. Entre 9h01 e 9h30, a lava-louça foi ligada. Às $11 \mathrm{~h} 00$, começou a fazer o almoço, ascendendo o forno do fogão a gás para assar carne, e entre $13 \mathrm{~h} 00$ e 14h00, acendeu um dos queimadores do fogão a gás para fritar carne. O cozimento no forno terminou às 14h10. Entre 14h11 e 16h00, realizou-se a limpeza na cozinha. Entre $18 \mathrm{~h} 00$ e 19h40, os usuários ocuparam o ambiente para jantar.

Nos eventos descritos anteriormente, as janelas e as portas somente foram abertas durante o cozimento. Entre $11 \mathrm{~h} 00$ e $11 \mathrm{~h} 29$, todas as portas e as janelas estavam fechadas. Às 11h30, a janela 1 (J1) foi aberta. Às 11h40, abriu-se as janelas 1 e 2 (J1 e J2). Às 11h50, as janelas 1 e 2 (J1 e J2) permaneceram abertas e ligou-se o exaustor. Entre $12 \mathrm{~h} 00$ e 12h29, as janelas 1 e 2 (J1 e J2) permaneceram abertas, o exaustor ligado e a porta $3(\mathrm{P} 3)$ aberta. Entre $12 \mathrm{~h} 30$ e $14 \mathrm{~h} 10$, as janelas 1 e 2 (J1 e J2), e também a porta 3 (P3) permaneceram na mesma posição das $12 \mathrm{~h} 00$. 
No dia 17 de janeiro de 2006, não houve atividade do usuário entre 0h00 e 8h20. Entre $8 \mathrm{~h} 21$ e $8 \mathrm{~h} 40$, eles estavam preparando e tomando café da manhã. Entre 8h41 e 8h55, a lava-louça foi ligada. Entre $11 \mathrm{~h} 00$ e 12h40, começou a fazer o almoço, acendendo o forno do fogão a gás para assar carne e o fogão para fritar carne, às 12h10, terminou-se a fritura. Entre $13 \mathrm{~h} 00$ e 13h20, realizou-se a limpeza na cozinha. Entre 16 h00 e 16h20, os usuários ocuparam o ambiente para tomar café da tarde. Entre 19 h15 e 19 h40, realizou-se o jantar.

Nos eventos descritos anteriormente, as janelas e as portas somente foram abertas durante o cozimento. Entre $11 \mathrm{~h} 00$ e $11 \mathrm{~h} 29$, todas as portas e as janelas estavam fechadas. Às 11h30, a janela 1 (J1) foi aberta. Às 11h40, abriram-se as janelas 1 e 2 (J1 e J2). Às 11h50, as janelas 1 e 2 (J1 e J2) permaneceram abertas e ligou-se o exaustor. Entre $12 \mathrm{~h} 00$ e 12h10, as janelas 1 e 2 (J1 e J2) permaneceram abertas, o exaustor ligado e a porta 3 (P3) aberta. Entre 12h11 e 12h20, as janelas 1 e 2 (J1 e J2) e a porta 3 (P3) permaneceram na mesma posição das 12h00. Entre 12h21 e 12h40, somente a janela 1 (J1) ficou aberta.

\subsection{Sala}

A medição de concentração, temperatura e umidade relativa na sala foram realizadas nos dias 13 e 18 de janeiro de 2006, iniciando à 0 h00 e finalizando às 23h30. Nos minutos que antecedem a medição, as janelas e as portas foram fechadas, minimizando as trocas de ar externo. Para localizar as portas, as janelas, a mobília e os equipamentos, na Figura 15, apresenta-se o croqui da sala de estar, sala de jantar, hall social e hall de entrada. 


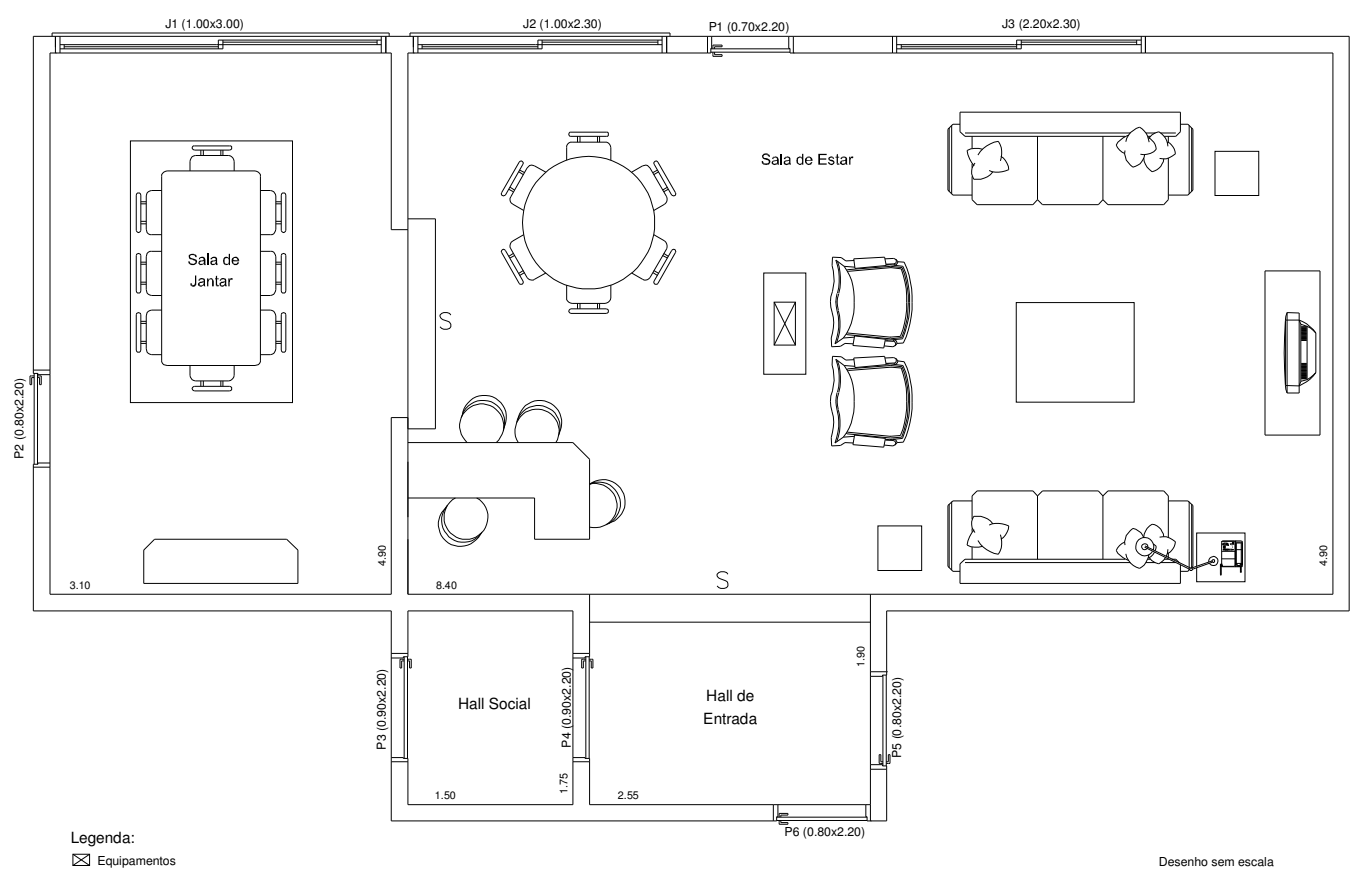

Figura 15 - Croqui da sala de estar, sala de jantar, hall social e hall de entrada, com o posicionamento dos equipamentos, das janelas, das portas e da mobília.

No dia 13 de janeiro de 2006, entre 0h00 e 1h00, os usuários ficaram assistindo televisão na sala de estar. Entre $0 \mathrm{~h} 31$ e $8 \mathrm{~h} 00$, não houve atividade do usuário neste ambiente. Entre 9 h30 e 10h00, realizou-se a proteção do piso no hall social para pintar as paredes do mesmo. Entre $10 \mathrm{~h} 01$ e $11 \mathrm{~h} 20$, as paredes foram lixadas. Entre 11h21 e 11h31, varreu-se o chão do hall social. Entre 13h31 e 14h00, os usuários assistiram televisão na sala de estar. Entre 14h01 e 17h20, executou-se novamente a pintura nas paredes do hall social. Entre 17h21 e 17h45, fez-se a limpeza do piso no hall de entrada e no hall social. Entre $18 \mathrm{~h} 40$ e 23h30, os usuários voltaram a assistir televisão na sala de estar.

Nas atividades descritas anteriormente, as janelas e as porta somente foram abertas durante a pintura, com exceção da porta 4 (P4), que permaneceu aberta durante toda a amostragem. Entre $11 \mathrm{~h} 31$ e 13h30, abriu-se a janela 3 (J3). Às 11h51, abriu-se a janela 2 (J2). Às 12h31, abriu-se a janela 1 (J1). Entre $15 \mathrm{~h} 40$ e $17 \mathrm{~h} 20$, a janela 3 (J3) ficou aberta. Às 16h01, abriu-se a janela 2 (J2). Às 16h31, a janela 1 (J1) foi aberta. 
No dia 18 de janeiro de 2006, entre 0h00 e 8h30, não houve atividade dos usuários neste ambiente. Entre $8 \mathrm{~h} 31$ e 10h30, eles estavam assistindo televisão. Entre 14h30 e 15h00, realizou-se a arrumação dos móveis para a limpeza na sala de estar, na sala de jantar e no hall de entrada. Às $15 \mathrm{~h} 00$, foi tirado pó dos móveis. Às $15 \mathrm{~h} 40$, varreu-se o chão das salas e do hall de entrada. Às 16h30, fez-se a limpeza do piso com pano úmido. Entre 19 h00 e 23h30, os usuários ficaram assistindo televisão na sala de estar.

Nas atividades descritas anteriormente, todas as janelas e as portas permaneceram fechadas durante a amostragem, com exceção da porta 4 (P4) que ficou aberta.

\subsubsection{3. Área de serviço}

$\mathrm{Na}$ área de serviço, a amostragem realizou-se no dia 14 de janeiro de 2006, iniciando à 0 h00 e finalizando às $23 \mathrm{~h} 30$. Antes de começar as medições, as janelas e as portas foram fechadas, minimizando as trocas de ar externo. Para localizar as portas, as janelas, a mobília e os equipamentos, na Figura 16, apresenta-se o croqui da área de serviço.

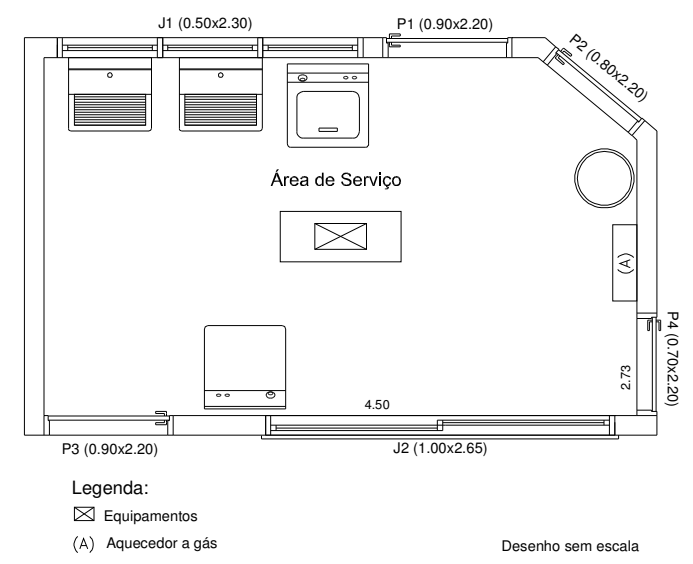

Figura 16 - Croqui da área de serviço, com o posicionamento dos equipamentos, das janelas, das portas e da mobília. 
No dia 14 de janeiro de 2006, entre 0h00 e 8h00, não houve atividade dos usuários neste ambiente. Entre $8 \mathrm{~h} 20$ e 8h50, aqueceu-se água do banho com o aquecedor a gás. Entre 9h30 e 10h15, lavou-se roupa na máquina. Entre $11 \mathrm{~h} 20$ e 12h20, fez-se o almoço na cozinha. Entre $13 \mathrm{~h} 00$ e 13h10, recolheu-se roupas no varal. Entre $13 \mathrm{~h} 30 \mathrm{e}$ 13h40, arrumou-se o ambiente para colocar uma prateleira na parede. Entre 13h41 e 14h10, fez-se os furos na parede. Entre $14 \mathrm{~h} 11$ e $15 \mathrm{~h} 00$, as tábuas da prateleira foram serradas. Entre 15h01 e 16h00, varreu-se o chão da área de serviço. Entre 16h01 e 16h40, lavou-se o mesmo chão. Entre 21 h20 e 22h30, aqueceu-se água do banho com o aquecedor a gás.

Nas atividades descritas anteriormente, as portas e as janelas somente foram abertas durante a colocação da prateleira e limpeza do chão. Entre $14 \mathrm{~h} 00$ e 14h10, abriu-se a janela 2 (J2). Entre 14h20 e 14h30, a janela 1 (J1) estava aberta. Entre 14h31 e 14h40, abriram-se a janela 1 (J1) e a janela 2 (J2). Entre $14 \mathrm{~h} 41$ e $14 \mathrm{~h} 50$, a janela 1 (J1) ficou aberta. Entre $14 \mathrm{~h} 51$ e 15h00, abriram-se a janela 1 (J1) e a janela 2 (J2). Entre $15 \mathrm{~h} 20$ e $15 \mathrm{~h} 30$, abriu-se a janela 2 (J2). Entre $15 \mathrm{~h} 31$ e $15 \mathrm{~h} 40$, a janela 1 (J1) e a janela 2 (J2) ficaram abertas.

\subsection{Dormitório}

O dormitório foi amostrado no dia 15 de janeiro de 2006, começando à 0 h00 e terminando às 23h30. Para as medições, as janelas e as portas foram fechadas no início do ensaio, para diminuir as trocas de ar externo. As portas, as janelas, a mobília e os equipamentos são mostrados na Figura 17.

Entre 0h00 e 9h00, no dia 15 de janeiro de 2006, não houve atividade do usuário neste ambiente, pois se encontravam dormindo. Entre $11 \mathrm{~h} 30$ e 13h05, o computador ficou ligado. Entre $13 \mathrm{~h} 06$ e 15h30, realizou-se a limpeza no dormitório. Às 13h40, tirou-se pó dos móveis e do colchão. Às 14h55, varreu-se o quarto. Às 15h00, realizou-se a limpeza do piso com pano úmido. 
Nas atividades descritas anteriormente, a portas e a janelas somente foram abertas durante a limpeza do dormitório. Entre $14 \mathrm{~h} 40$ e 15h20, abriu-se a janela 1 (J1).

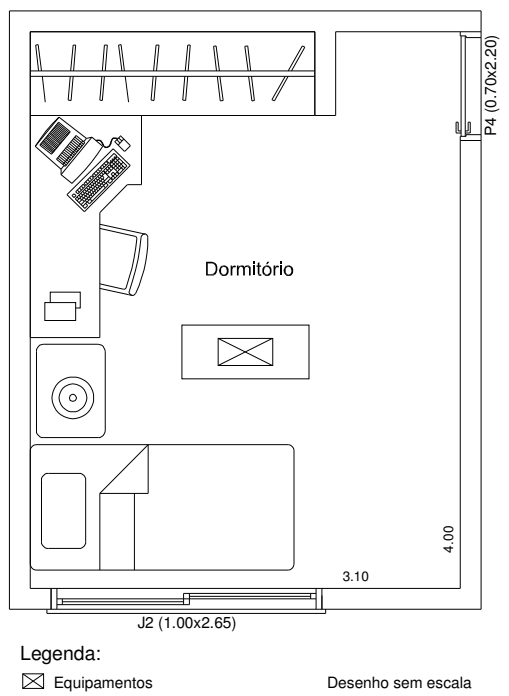

Figura 17 - Croqui do dormitório, com o posicionamento dos equipamentos, das janelas, das portas e da mobília.

\subsection{Banheiro}

A medição no banheiro ocorreu nos dias 16 e 19 de janeiro de 2006, tendo início à 0h00 e término às 23h30. Alguns minutos antes das medições, as janelas e as portas foram fechadas, para diminuir as trocas de ar externo. As portas, as janelas, a mobília e os equipamentos são apresentados na Figura 18.

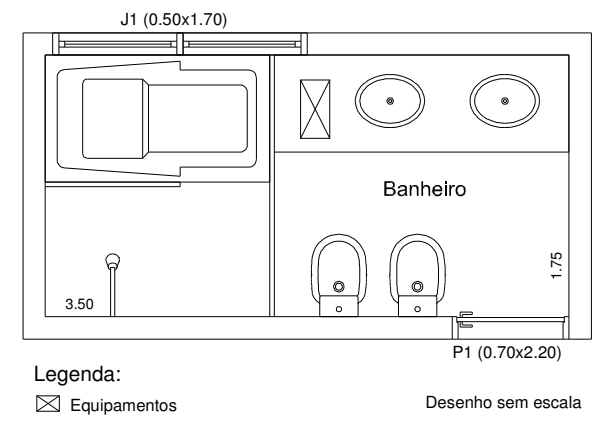

Figura 18 - Croqui do banheiro, com o posicionamento dos equipamentos, das janelas, das portas e da mobília. 
No dia 16 de janeiro de 2006, entre 0h00 e 7h00, não houve atividade dos usuários neste ambiente. Entre 7h01 e 7h10, escovou-se os dentes. Entre 8h21 e 8h26, usou-se a bacia sanitária. Entre $10 \mathrm{~h} 00$ e 11h00, fez-se limpeza no banheiro. Entre 14h50 e $15 \mathrm{~h} 50$, encheu a banheira de água quente. Entre $16 \mathrm{~h} 00$ e 16h30, um usuário tomou banho na banheira.

Nas atividades descritas anteriormente, as portas e as janelas não foram abertas durante o banho. Entre $22 \mathrm{~h} 50$ e $23 \mathrm{~h} 30$, abriu-se a janela 1 (J1).

No dia 19 de janeiro de 2006, entre 0h00 e 8h00, não houve atividade dos usuários neste ambiente. Entre 8h01 e 8h10, escovou-se os dentes. Entre $11 \mathrm{~h} 50$ e 12h00, usou-se a bacia sanitária. Entre $13 \mathrm{~h} 00$ e 14h00, encheu a banheira com água quente. Entre $16 \mathrm{~h} 30$ e 17h00, um usuário tomou banho na banheira.

Nas atividades descritas anteriormente, a janelas 1 (J1) somente foi aberta entre $21 \mathrm{~h} 40$ e $23 \mathrm{~h} 30$. 


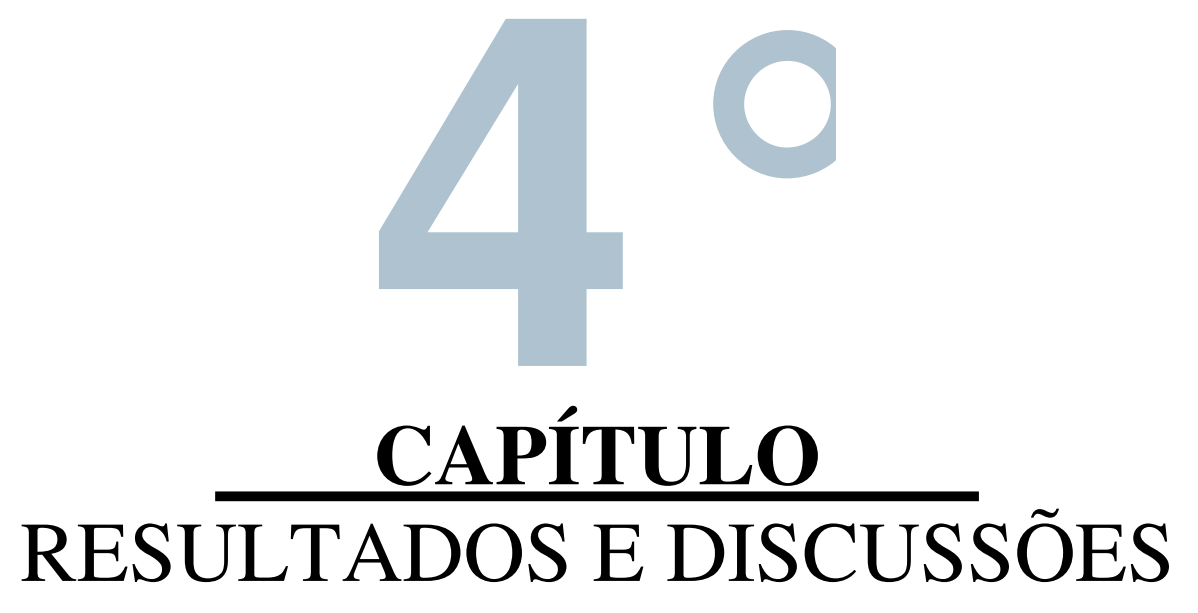




\section{RESULTADOS E DISCUSSÃO}

\subsection{Resultados}

A seguir apresentam-se os resultados quantitativos dos programas experimentais de campo ( $\left(1^{\mathrm{a}}\right.$ e $2^{\mathrm{a}}$ fase), bem como as análises e discussões dos mesmos:

\subsubsection{Programa experimental de campo ( $1^{\mathrm{a}}$ fase $)$}

As medições nos ambientes internos da RMSP apontaram os seguintes valores mínimos e máximos, além dos valores médios, calculados pela equação da média aritmética entre os valores da concentração em massa de aerodispersóides, conforme apresentado na Figura 19.

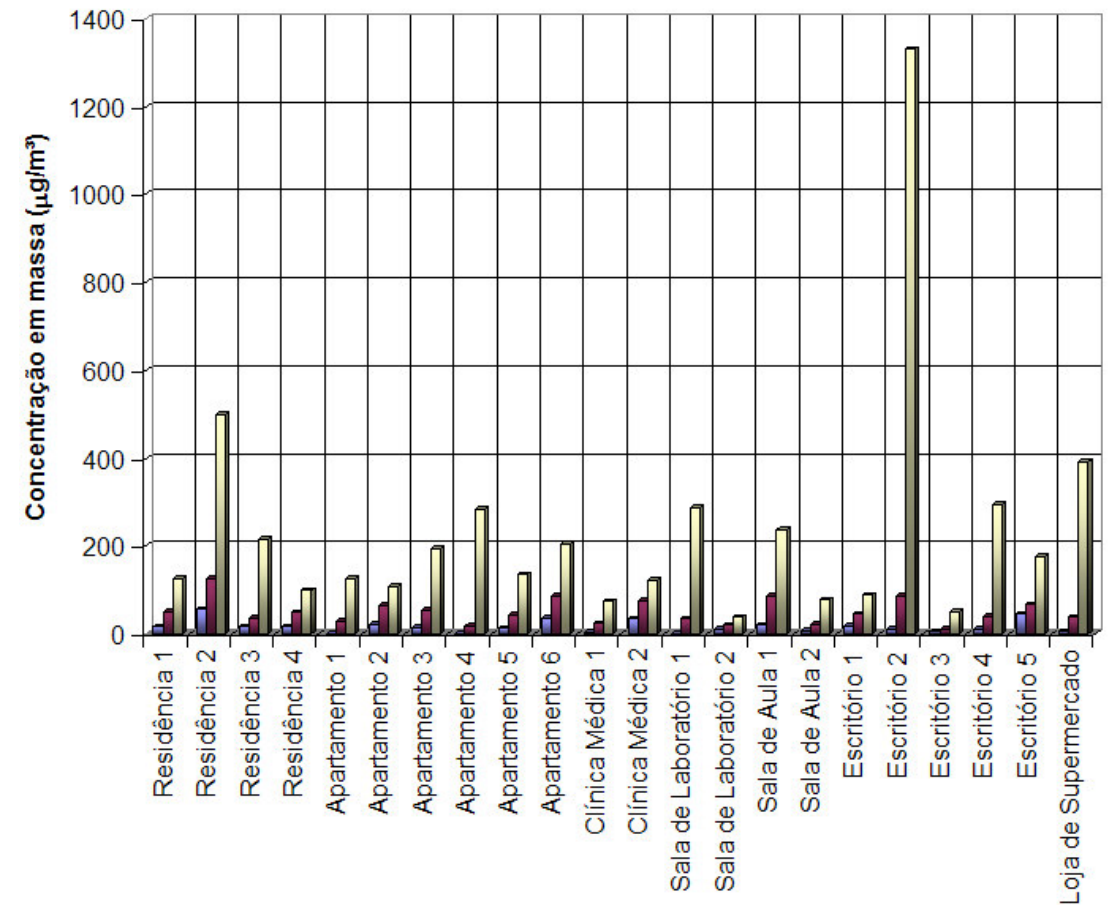

Figura 19 - Concentração em massa de aerodispersóides para os ambientes internos localizados na RMSP. 
Os valores, apresentados na Figura 19, indicam a concentração em massa de aerodispersóides para os ambientes internos em quatro residências, seis apartamentos, duas clínicas médicas, dois laboratórios, duas salas de aula, cinco escritórios e uma loja de supermercado.

Em dois ambientes, residência 2 e escritório 2, a máxima concentração em massa de aerodispersóides foi de $500 \mu \mathrm{g} / \mathrm{m}^{3}$ e $1.330 \mu \mathrm{g} / \mathrm{m}^{3}$, respectivamente, sendo atribuído ao fato de cozinhar e reformar.

No supermercado a máxima concentração em massa de aerodispersóides foi de 391 $\mu \mathrm{g} / \mathrm{m}^{3}$, em função da variedade de produtos existentes e do maior fluxo de pessoas, porém era de se esperar um valor maior de aerodispersóides em relação a outros ambientes. No entanto, como esses valores foram superados por outros dois ambientes que não possuem as características do supermercado, isso parece indicar que nestes ambientes os aerodispersóides pode estar sendo gerados, segundo Allard (1989), pela emissão dos materiais constituintes, emissão de produtos químicos, reação química dos materiais com o ar, com um outro material ou com a umidade, degradação dos materiais, reação fotoquímica, reação biológica do metabolismo humano e dos materiais, contaminação pelo ar externo e interação destes fenômenos.

A RE $n^{\circ} 9$ (ANVISA, 2003) estabelece como referência de qualidade do ar interno para aerodispersóides totais o valor de concentração máxima igual a $80 \mu \mathrm{g} / \mathrm{m}^{3}$. Porém, na residência 2, o valor da concentração média em massa de aerodispersóides foi de $125 \mu \mathrm{g} / \mathrm{m}^{3}$. No apartamento 6 e na sala de aula 1 , as concentrações médias foram iguais a $87 \mu \mathrm{g} / \mathrm{m}^{3}$. No escritório 2 , este valor foi de $86 \mu \mathrm{g} / \mathrm{m}^{3}$.

Identificam-se, na Tabela 7, os valores médios de temperatura, umidade relativa, concentração em massa, referência de concentração e condições do tempo (ensolarado ou nublado), durante as medições de concentração em massa de aerodispersóides, para os ambientes internos localizados na RMSP. 
Tabela 7 - Valores médios de temperatura, umidade relativa, concentração em massa, referência de concentração e condições do tempo (ensolarado e nublado), durante as medições de concentração em massa de aerodispersóides, para os ambientes internos localizados na RMSP.

\begin{tabular}{lccccc}
\hline Ambientes Internos & $\begin{array}{c}\text { Temp. } \\
\text { média } \\
\left({ }^{\circ} \mathbf{C}\right)\end{array}$ & $\begin{array}{c}\text { Umidade } \\
\text { relativa } \\
\text { média }(\boldsymbol{\%})\end{array}$ & $\begin{array}{c}\text { Concentração } \\
\text { média em } \\
\text { massa }\left(\boldsymbol{\mu g} / \mathbf{m}^{3}\right)\end{array}$ & $\begin{array}{c}\text { RE n } \\
(\mathbf{A N V I S A} \\
\mathbf{2 0 0 3})\end{array}$ & $\begin{array}{c}\text { Condições } \\
\text { do tempo }\end{array}$ \\
\hline Residência 01 & 22,6 & 55,4 & 51 & 80 & Nublado \\
\hline Residência 02 & 20,9 & 54,5 & 125 & 80 & Ensolarado \\
\hline Residência 03 & 20,8 & 57,5 & 36 & 80 & Nublado \\
\hline Residência 04 & 22,1 & 47,8 & 48 & 80 & Ensolarado \\
\hline Apartamento 01 & 21,7 & 50,6 & 29 & 80 & Ensolarado \\
\hline Apartamento 02 & 20,6 & 50,7 & 65 & 80 & Nublado \\
\hline Apartamento 03 & 22,8 & 54,7 & 54 & 80 & Nublado \\
\hline Apartamento 04 & 22,1 & 50,7 & 18 & 80 & Ensolarado \\
\hline Apartamento 05 & 21,3 & 43,1 & 43 & 80 & Ensolarado \\
\hline Apartamento 06 & 20,5 & 58,4 & 87 & 80 & Nublado \\
\hline Clínica Médica 1 & 21,0 & 56,8 & 23 & 80 & Nublado \\
\hline Clínica Médica 2 & 23,7 & 41,5 & 76 & 80 & Ensolarado \\
\hline Sala de Laboratório 1 & 23,0 & 49,4 & 35 & 80 & Ensolarado \\
\hline Sala de Laboratório 2 & 22,6 & 50,5 & 20 & 80 & Nublado \\
\hline Sala de Aula 1 & 21,7 & 48,3 & 87 & 80 & Ensolarado \\
\hline Sala de Aula 2 & 20,9 & 44,3 & 22 & 80 & Ensolarado \\
\hline Escritório 1 & 19,2 & 53,1 & 45 & 80 & Nublado \\
\hline Escritório 2 & 20,0 & 51,3 & 86 & 80 & Ensolarado \\
\hline Escritório 3 & 20,7 & 53,0 & 11 & 80 & Nublado \\
\hline Escritório 4 & 20,7 & 53,7 & 39 & 80 & Nublado \\
\hline Escritório 5 & 22,3 & 54,7 & 67 & 80 & Ensolarado \\
\hline Loja de Supermercado & 22,4 & 53,8 & 38 & 80 & Nublado \\
\hline & & & & & \\
\hline
\end{tabular}

A seguir, na tabela 8, apresentam-se as principais características dos ambientes internos, tanto para concentração em massa, quanto para concentração em número. 
Tabela 8 - Principais características dos ambientes internos.

\begin{tabular}{|c|c|c|c|c|c|}
\hline Ambientes Internos & $\begin{array}{c}\text { Janelas e } \\
\text { portas } \\
\text { fechadas } \\
\text { à } \\
\text { noite }\end{array}$ & $\begin{array}{c}\text { Janelas e } \\
\text { portas } \\
\text { fechadas } \\
\text { ao } \\
\text { dia }\end{array}$ & $\begin{array}{c}\text { Presença } \\
\text { de queima } \\
\text { por } \\
\text { combus- } \\
\text { tão }\end{array}$ & $\begin{array}{c}\text { Móveis de } \\
\text { madeira } \\
\text { ou } \\
\text { divisórias }\end{array}$ & $\begin{array}{c}\text { Presença } \\
\text { de } \\
\text { fumaça } \\
\text { de } \\
\text { cigarro }\end{array}$ \\
\hline Residência 01 & $\operatorname{sim}$ & não & $\operatorname{sim}$ & $\operatorname{sim}$ & $\overline{\text { não }}$ \\
\hline Residência 02 & $\operatorname{sim}$ & não & $\operatorname{sim}$ & $\operatorname{sim}$ & $\operatorname{sim}$ \\
\hline Residência 03 & $\operatorname{sim}$ & não & $\operatorname{sim}$ & $\operatorname{sim}$ & não \\
\hline Residência 04 & $\operatorname{sim}$ & não & $\operatorname{sim}$ & $\operatorname{sim}$ & não \\
\hline Apartamento 01 & $\operatorname{sim}$ & não & $\operatorname{sim}$ & $\operatorname{sim}$ & não \\
\hline Apartamento 02 & $\operatorname{sim}$ & não & $\operatorname{sim}$ & $\operatorname{sim}$ & não \\
\hline Apartamento 03 & $\operatorname{sim}$ & não & $\operatorname{sim}$ & $\operatorname{sim}$ & não \\
\hline Apartamento 04 & $\operatorname{sim}$ & não & $\operatorname{sim}$ & $\operatorname{sim}$ & não \\
\hline Apartamento 05 & $\operatorname{sim}$ & não & $\operatorname{sim}$ & $\operatorname{sim}$ & não \\
\hline Apartamento 06 & $\operatorname{sim}$ & não & $\operatorname{sim}$ & $\operatorname{sim}$ & não \\
\hline Clínica Médica 1 & $\operatorname{sim}$ & não & não & $\operatorname{sim}$ & não \\
\hline Clínica Médica 2 & $\operatorname{sim}$ & não & não & $\operatorname{sim}$ & não \\
\hline Sala de Laboratório 1 & $\operatorname{sim}$ & $\operatorname{sim}$ & não & $\operatorname{sim}$ & não \\
\hline Sala de Laboratório 2 & $\operatorname{sim}$ & $\operatorname{sim}$ & não & $\operatorname{sim}$ & não \\
\hline Sala de Aula 1 & $\operatorname{sim}$ & $\operatorname{sim}$ & não & $\operatorname{sim}$ & não \\
\hline Sala de Aula 2 & $\operatorname{sim}$ & $\operatorname{sim}$ & não & $\operatorname{sim}$ & não \\
\hline Escritório 1 & $\operatorname{sim}$ & $\operatorname{sim}$ & não & $\operatorname{sim}$ & não \\
\hline Escritório 2 & $\operatorname{sim}$ & $\operatorname{sim}$ & não & $\operatorname{sim}$ & não \\
\hline Escritório 3 & $\operatorname{sim}$ & $\operatorname{sim}$ & não & $\operatorname{sim}$ & não \\
\hline Escritório 4 & $\operatorname{sim}$ & $\operatorname{sim}$ & não & $\operatorname{sim}$ & não \\
\hline Escritório 5 & $\operatorname{sim}$ & $\operatorname{sim}$ & não & $\operatorname{sim}$ & não \\
\hline Loja de Supermercado & $\operatorname{sim}$ & não & $\operatorname{sim}$ & $\operatorname{sim}$ & $\operatorname{sim}$ \\
\hline
\end{tabular}

As tabelas 7 e 8 mostram a dificuldade em relacionar a temperatura, umidade relativa, radiação e as principais características aos ambientes internos de cada edifícios. O problema foi estabelecer relação entre estes parâmetros e os edifícios, devido à complexidade do assunto. Portanto, na segunda fase, estudou-se somente 
um edifício, detalhando as partes envolvidas, durante uma semana, em função das principais fontes de emissão.

Adgate et al. (2002) observaram que a concentração interna de partículas finas, menores que $2,5 \mu \mathrm{m}$, pode ser maior devido às atividades dos usuários. Em seus estudos os pesquisadores observaram também que as pessoas permanecem $90 \%$ do tempo em ambientes internos e os outros $10 \%$ do tempo em ambientes externos ou no trânsito. Portanto, apresentam-se, na Figura 20, as porcentagens do tempo de medição da concentração em massa de aerodispersóides acima de $80 \mu \mathrm{g} / \mathrm{m}^{3}$ nos ambientes internos dos edifícios localizados na RMSP, a fim de analisar quanto tempo as pessoas estão sujeitas à poluição por aerodispersóides.

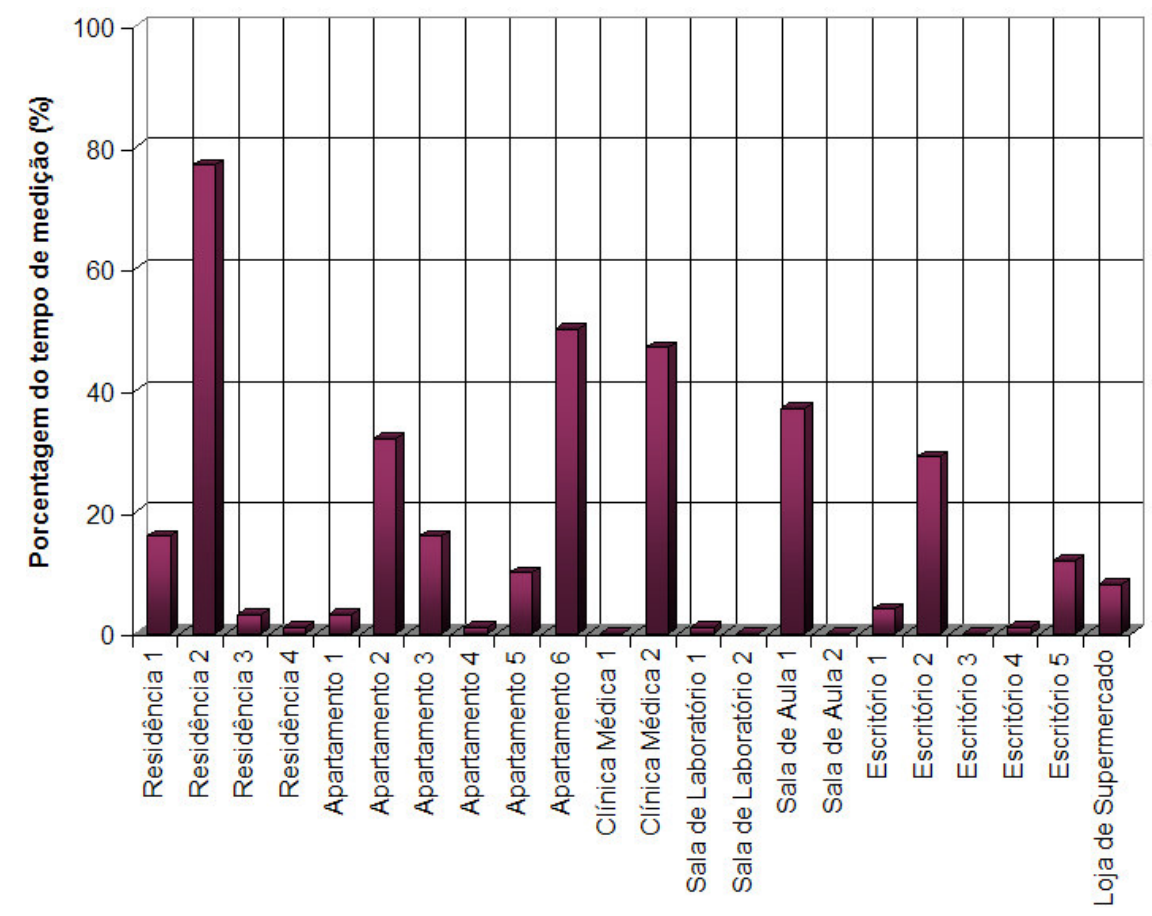

Figura 20 - Porcentagens do tempo de medição da concentração em massa de aerodispersóides acima de $80 \mu \mathrm{g} / \mathrm{m}^{3}$, para os ambientes internos localizados na RMSP.

A Figura 20 apresenta as porcentagens do tempo de medição da concentração em massa de aerodispersóides acima de $80 \mu \mathrm{g} / \mathrm{m}^{3}$ para os ambientes internos localizados 
na RMSP. Observa-se que a porcentagem do tempo foi de: $77 \%$ na residência $2,50 \%$ no apartamento 6, 47\% na clínica médica $2,37 \%$ na sala de aula $1,32 \%$ no apartamento 2, 29\% no escritório 2 e para os demais ambientes, o tempo foi menor que $20 \%$. No entanto, se os valores acima de $80 \mu \mathrm{g} / \mathrm{m}^{3}$ trazem prejuízo à saúde, então nos $90 \%$ do tempo permanecendo em mais de um destes lugares, as pessoas aumentaram o risco de contrair doenças devido à exposição de aerodispersóides.

A seguir, na Figura 21, apresentam-se as porcentagens do tempo de permanência das pessoas em cada edifícios, como nas residências ou apartamentos, escritórios ou salas de aula e outros locais, segundo Adgate et al, 2002.

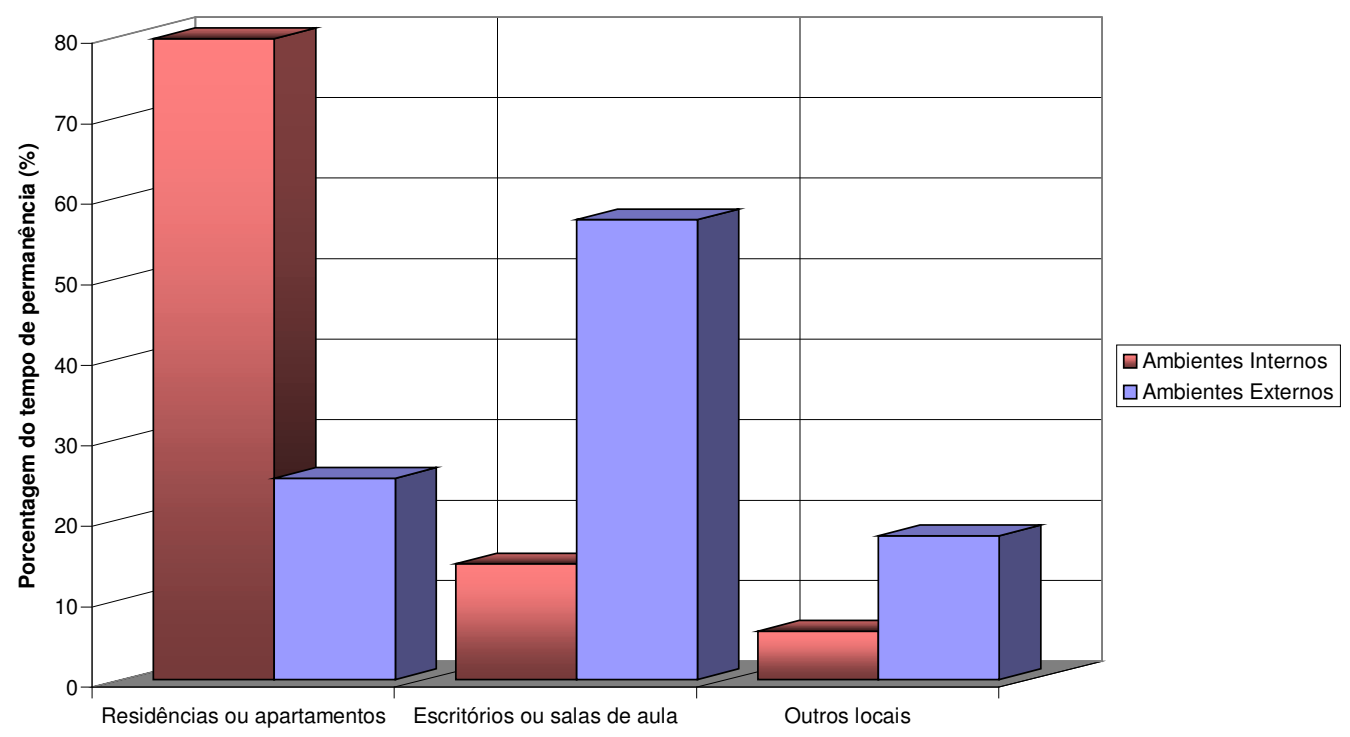

Figura 21 - Porcentagens do tempo médio de permanência das pessoas nos ambientes internos e externos, durante vinte e quatro horas. Fonte: Adgate et al., 2002.

Na Figura 21 para 90\% do tempo de permanência das pessoas em ambientes internos, 79,63\% ficaram nas residências ou nos apartamentos, 14,35\% ficaram nos escritórios ou nas salas de aula e 6,02\% ficaram em outros locais. Para $10 \%$ do tempo de permanência das pessoas em ambientes externos, 25\% ficaram nas residências ou nos apartamentos, 57,14\% ficaram nos escritórios ou nas salas de aula e $17,86 \%$ ficaram em outros locais. 
As porcentagens do tempo de medição e de permanência das pessoas nas residências ou nos apartamentos indicam valores elevados, contribuindo igualmente para agravar a saúde dos usuários.

Em seguida, na Figura 22, apresentam-se as porcentagens acumuladas do tempo que a concentração média em massa de aerodispersóides ficou entre 0 e $80 \mu \mathrm{g} / \mathrm{m}^{3}, 81$ e $100 \mu \mathrm{g} / \mathrm{m}^{3}$, 101 e $120 \mu \mathrm{g} / \mathrm{m}^{3}$, e maior que $121 \mu \mathrm{g} / \mathrm{m}^{3}$. Os valores da concentração média em massa foram analisados estatisticamente pelas medidas de posição, obtendo o desvio padrão de $33 \mu \mathrm{g} / \mathrm{m}^{3}$, a variância de $1.070 \mu \mathrm{g}^{2} / \mathrm{m}$, o valor médio de $95 \mu \mathrm{g} / \mathrm{m}^{3}$ e o coeficiente de variação de $34 \%$.

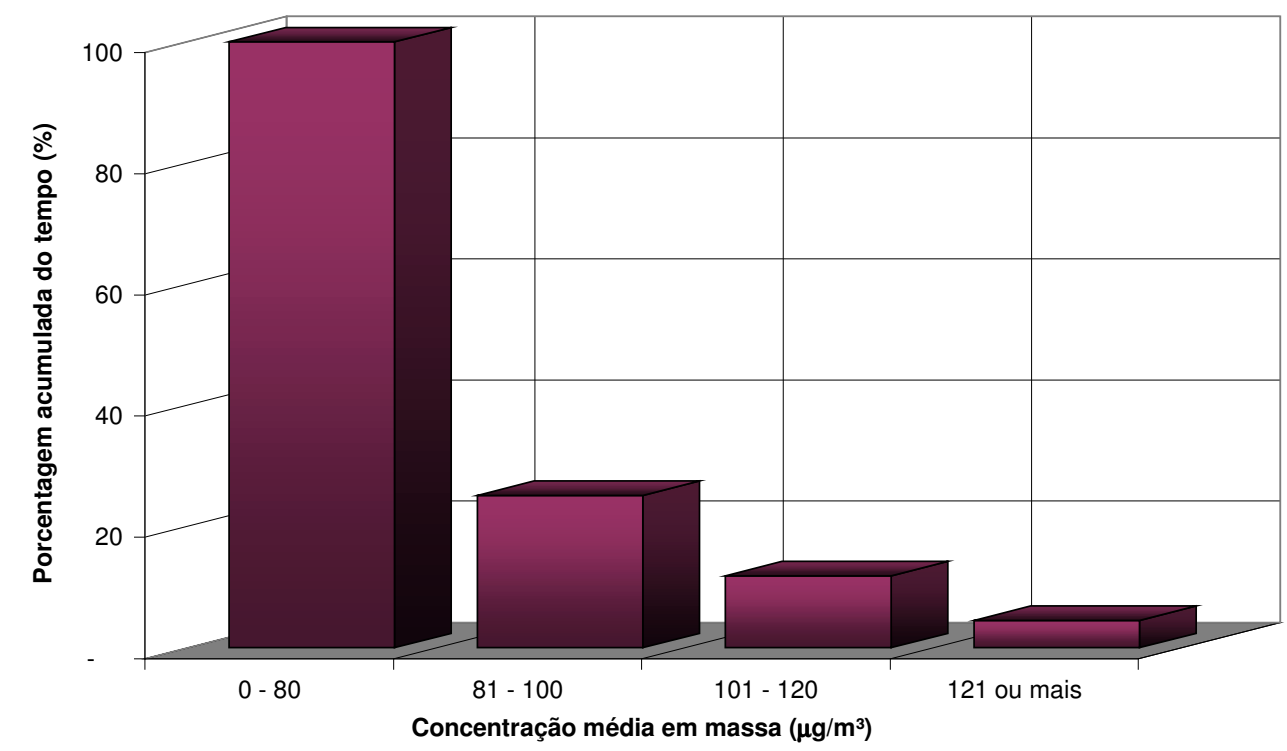

Figura 22 - Porcentagens acumuladas do tempo que a concentração média em massa de aerodispersóides ficou entre 0 e $80 \mu \mathrm{g} / \mathrm{m}^{3}, 81$ e $100 \mu \mathrm{g} / \mathrm{m}^{3}, 101$ e $120 \mu \mathrm{g} / \mathrm{m}^{3}$, e maior que $121 \mu \mathrm{g} / \mathrm{m}^{3}$.

Na Figura 22 observam-se as porcentagens acumuladas do tempo da concentração média em massa de $100 \%$ entre 0 e $80 \mu \mathrm{g} / \mathrm{m}^{3}, 25 \%$ entre 81 e $100 \mu \mathrm{g} / \mathrm{m}^{3}, 12 \%$ entre 101 e $120 \mu \mathrm{g} / \mathrm{m}^{3}$, e $5 \%$ maior que $121 \mu \mathrm{g} / \mathrm{m}^{3}$.

A seguir, na Figura 23, são apresentados os resultados para os mesmos ambientes internos descritos anteriormente, porém utilizando o P-Trak Ultrafine Particle 
Counter. Estes resultados apontam os seguintes valores mínimos e máximos, além dos valores médios, calculados pela equação da média aritmética, usando as concentrações em número de aerodispersóides.

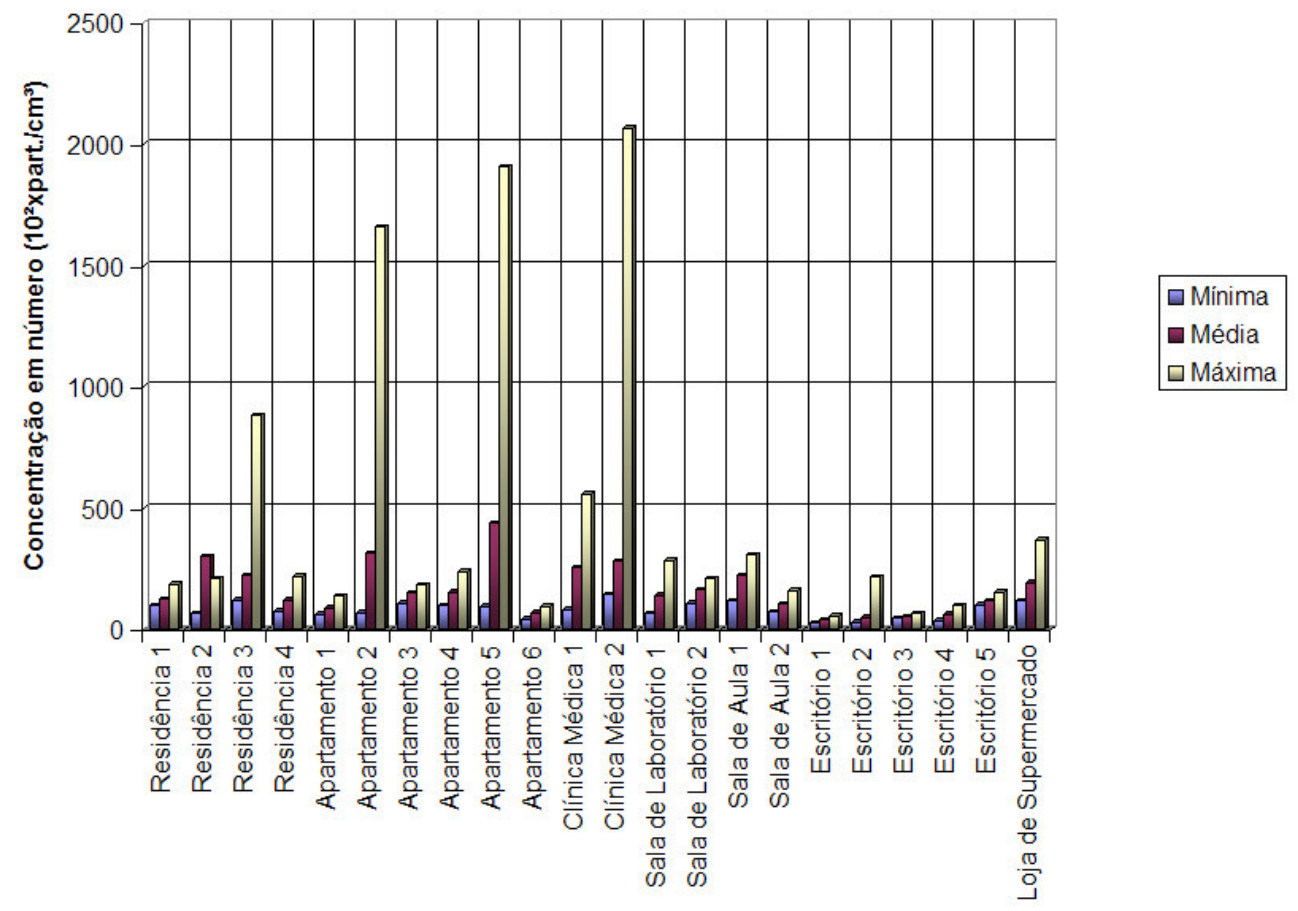

Figura 23 - Concentração em número de aerodispersóides para os ambientes internos localizados na RMSP.

Os valores, apresentados na Figura 23, indicam a concentração em número de aerodispersóides para os ambientes internos em quatro residências, seis apartamentos, duas clínicas médicas, dois laboratórios, duas salas de aula, cinco escritórios e uma loja de supermercado.

Em quatro ambientes, residência 3, apartamento 2 e 5 , e clínica médica 2, as concentrações máximas em número de aerodispersóides foram respectivamente de 88.300 part./cm 3 , 165.700 part. $/ \mathrm{cm}^{3}, 190.400$ part. $/ \mathrm{cm}^{3}$ e 206.600 part./cm ${ }^{3}$, sendo atribuído essas concentrações ao fato de alguma atividade ocupacional gerar aerodispersóides. Dessa forma, observa-se o mesmo comportamento para a concentração em massa de aerodispersóides apresentado anteriormente. 
Na residência 2 o valor da concentração média em número de aerodispersóides foi de 30.100 part. $/ \mathrm{cm}^{3}$. No apartamento 5, a concentração média foi de 43.800 part./$/ \mathrm{cm}^{3}$. No apartamento 2, este valor foi de 31.500 part. $/ \mathrm{cm}^{3}$. Na clínica médica 1 e 2, a concentração foi respectivamente de 25.600 e 28.200 part./ $\mathrm{cm}^{3}$. Na residência 3 , o valor foi de 22.200 part./cm ${ }^{3}$. Na sala de aula 1 , foi de 22.300 part. $/ \mathrm{cm}^{3}$.

Identificam-se, na Tabela 9, os valores médios de temperatura, umidade relativa, concentração em número e referência de concentração e as condições do tempo (ensolarado ou nublado), durante as medições de concentração em número de aerodispersóides, para os ambientes internos localizados na RMSP.

Nas Figuras 19 e 23 observam-se os valores máximos de concentração em massa e em número de aerodispersóides para os ambientes internos em cada edifícios da RMSP, significando algum evento ou atividade dos usuários. Na residência 2 e 3, Apartamento 2, Escritório 2 e 5, e clínica médica 2, os valores máximos de concentração não foram constantes durante as medições, atribuindo esse fato ao cozimento, fumaça de cigarro, limpeza, entre outros.

A tabela 9 mostra também a dificuldade em relacionar a temperatura, umidade relativa, concentração em número, referência de concentração e radiação nos ambientes internos para cada edifícios. O problema foi estabelecer relação entre estes parâmetros e os edifícios, também devido à complexidade do assunto. Igualmente atribuído a concentração em massa, na segunda fase, estudou-se somente um edifício, detalhando as partes envolvidas, em função das principais fontes de emissão. 
Tabela 9 - Valores médios de temperatura, umidade relativa, concentração em número, referência de concentração e condições do tempo (ensolarado e nublado), durante as medições de concentração em número de aerodispersóides, para os ambientes internos localizados na RMSP.

\begin{tabular}{lccccr}
\hline Ambientes Internos & $\begin{array}{c}\text { Temp. } \\
\text { média } \\
\left({ }^{\circ} \mathbf{C}\right)\end{array}$ & $\begin{array}{c}\text { Umidade } \\
\text { relativa } \\
\text { média }(\%)\end{array}$ & $\begin{array}{c}\text { Concentração } \\
\text { média em } \\
\text { número } \\
(\text { part./cm }\end{array}$ & $\begin{array}{c}\text { Morawska } \\
\text { et al. } \\
(\mathbf{1 9 9 9 )}\end{array}$ & $\begin{array}{r}\text { Condições } \\
\text { do tempo }\end{array}$ \\
\hline Residência 01 & 22,6 & 55,4 & 12.335 & 7.400 & Nublado \\
\hline Residência 02 & 20,9 & 54,5 & 30.107 & 7.400 & Ensolarado \\
\hline Residência 03 & 20,8 & 57,5 & 22.205 & 7.400 & Nublado \\
\hline Residência 04 & 22,1 & 47,8 & 12.142 & 7.400 & Ensolarado \\
\hline Apartamento 01 & 20,5 & 56,7 & 8.790 & 7.400 & Nublado \\
\hline Apartamento 02 & 20,0 & 54,9 & 31.511 & 7.400 & Nublado \\
\hline Apartamento 03 & 21,9 & 51,8 & 14.946 & 7.400 & Ensolarado \\
\hline Apartamento 04 & 21,6 & 48,4 & 15.455 & 7.400 & Ensolarado \\
\hline Apartamento 05 & 21,0 & 61,1 & 43.783 & 7.400 & Nublado \\
\hline Apartamento 06 & 20,6 & 51,2 & 6.889 & 7.400 & Nublado \\
\hline Clínica Médica 1 & 21,0 & 56,8 & 25.598 & 7.400 & Nublado \\
\hline Clínica Médica 2 & 24,0 & 42,9 & 28.182 & 7.400 & Ensolarado \\
\hline Sala de Laboratório 1 & 20,6 & 55,5 & 14.236 & 7.400 & Nublado \\
\hline Sala de Laboratório 2 & 22,2 & 54,5 & 16.478 & 7.400 & Nublado \\
\hline Sala de Aula 1 & 21,7 & 48,3 & 22.348 & 7.400 & Ensolarado \\
\hline Sala de Aula 2 & 20,9 & 44,3 & 10.437 & 7.400 & Ensolarado \\
\hline Escritório 1 & 19,2 & 53,1 & 4.060 & 7.400 & Nublado \\
\hline Escritório 2 & 20,0 & 51,3 & 4.966 & 7.400 & Ensolarado \\
\hline Escritório 3 & 20,7 & 53,0 & 5.366 & 7.400 & Nublado \\
\hline Escritório 4 & 20,7 & 53,7 & 6.161 & 7.400 & Nublado \\
\hline Escritório 5 & 22,3 & 54,7 & 11.906 & 7.400 & Ensolarado \\
\hline Loja de Supermercado & 22,4 & 53,8 & 19.390 & 7.400 & Nublado \\
\hline & & & & \\
\hline
\end{tabular}

Na Figura 24 apresentam-se as porcentagens do tempo de medição da concentração em número de aerodispersóides acima de 7.400 part./ $\mathrm{cm}^{3}$, para os ambientes internos localizados na RMSP. 


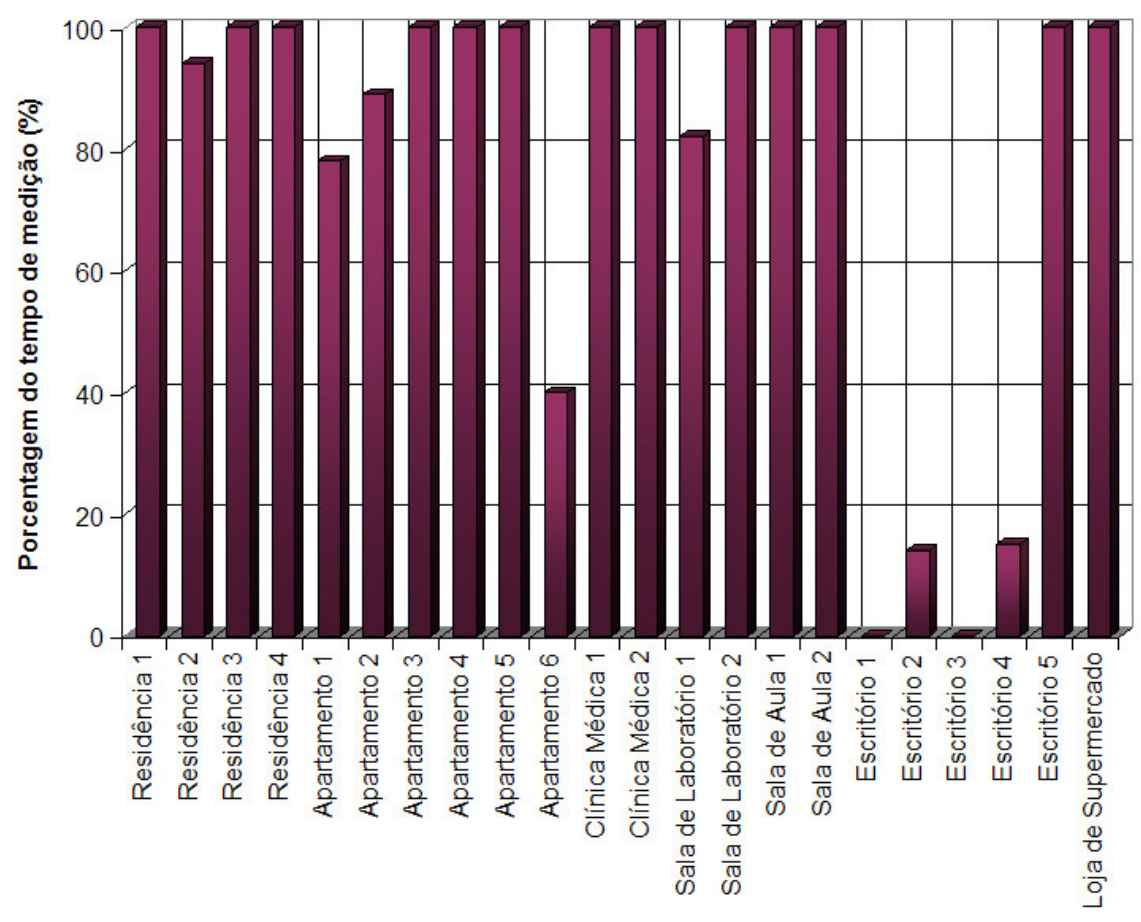

Figura 24 - Porcentagens do tempo de medição da concentração em número de aerodispersóides acima de 7.400 part./. $\mathrm{cm}^{3}$, para os ambientes internos localizados na RMSP.

Observa-se, na Figura 24, que a porcentagem do tempo de medição da concentração em número de aerodispersóides acima de 7.400 part. $/ \mathrm{cm}^{3}$ foi de: $94 \%$ na residência 2 , $78 \%$ no apartamento $1,89 \%$ no apartamento $2,40 \%$ no apartamento $6,82 \%$ na sala do laboratório 1 e 14\% para o escritório 2. Para os demais ambientes internos, as porcentagens foram iguais a $100 \%$. Portanto, atribuem-se os mesmos comentários realizados à concentração em massa.

Em seguida, na Figura 25, apresentam-se as porcentagens acumuladas do tempo que

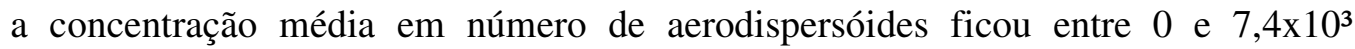
part. $/ \mathrm{cm}^{3}$, entre 7,5 e $10 \times 10^{3}$ part. $/ \mathrm{cm}^{3}$, entre 10,1 e $12 \times 10^{3}$ part./ $\mathrm{cm}^{3}$, e maior que $12,1 \times 10^{3}$ part. $/ \mathrm{cm}^{3}$. Os valores da concentração média em número foram analisados estatisticamente pelas medidas de posição, obtendo o desvio padrão de 2.923 part./cm ${ }^{3}$, a variância de 8.543 part. ${ }^{2} / \mathrm{cm}$, o valor médio de 10.675 part. $/ \mathrm{cm}^{3}$ e o coeficiente de variação de $27 \%$. 


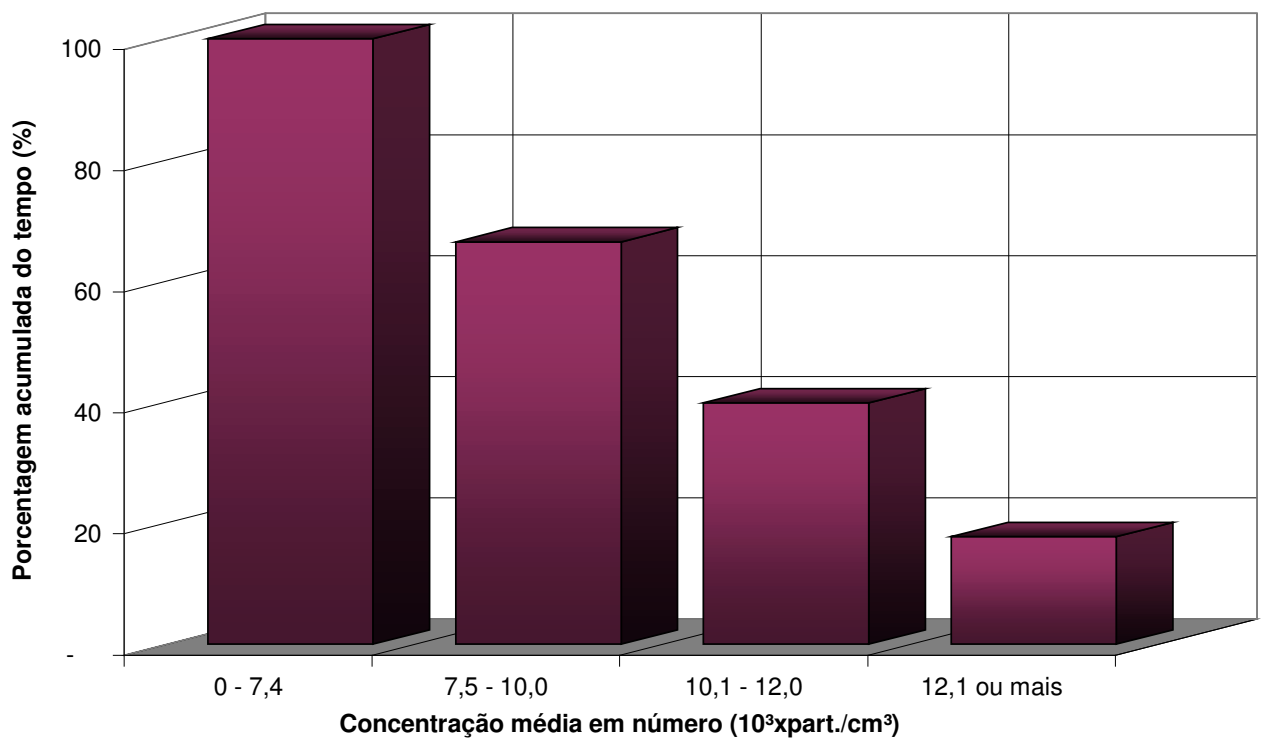

Figura 25 - Porcentagens acumuladas do tempo que a concentração em número de aerodispersóides ficou entre 0 e $7,4 \times 10^{3}$ part. $/ \mathrm{cm}^{3}$, entre 7,5 e $10 \times 10^{3}$ part. $/ \mathrm{cm}^{3}$, entre 10,1 e $12 \times 10^{3}$ part. $/ \mathrm{cm}^{3}$, e maior que $12,1 \times 10^{3}$ part. $/ \mathrm{cm}$.

Na Figura 25 observam-se as porcentagens acumuladas do tempo da concentração média em número de $100 \%$ entre 0 e $7,4 \times 10^{3}$ part./ $/ \mathrm{cm}^{3}, 66 \%$ entre 7,5 e $10 \times 10^{3}$ part. $/ \mathrm{cm}^{3}, 40 \%$ entre 10,1 e $12 \times 10^{3}$ part. $/ \mathrm{cm}^{3}$, e $18 \%$ maior que $12,1 \times 10^{3}$ part. $/ \mathrm{cm}^{3}$.

\subsubsection{Programa experimental de campo ( $2^{\mathrm{a}}$ fase $)$}

Entre as Figuras 26 e 31 apresentam-se os gráficos da concentração em massa e em número de aerodispersóides, da temperatura, da umidade relativa e do valor de referência, segundo RE $\mathrm{n}^{\circ} 9$ (ANVISA, 2003), nos ambientes internos do apartamento, sendo eles: cozinha, sala de estar, área de serviço, dormitório e banheiro. Além disso, identificam-se as fontes de aerodispersóides durante as vinte e quatro horas de medição, como: cozimento, limpeza, pintura, televisão, computador, entre outros. 


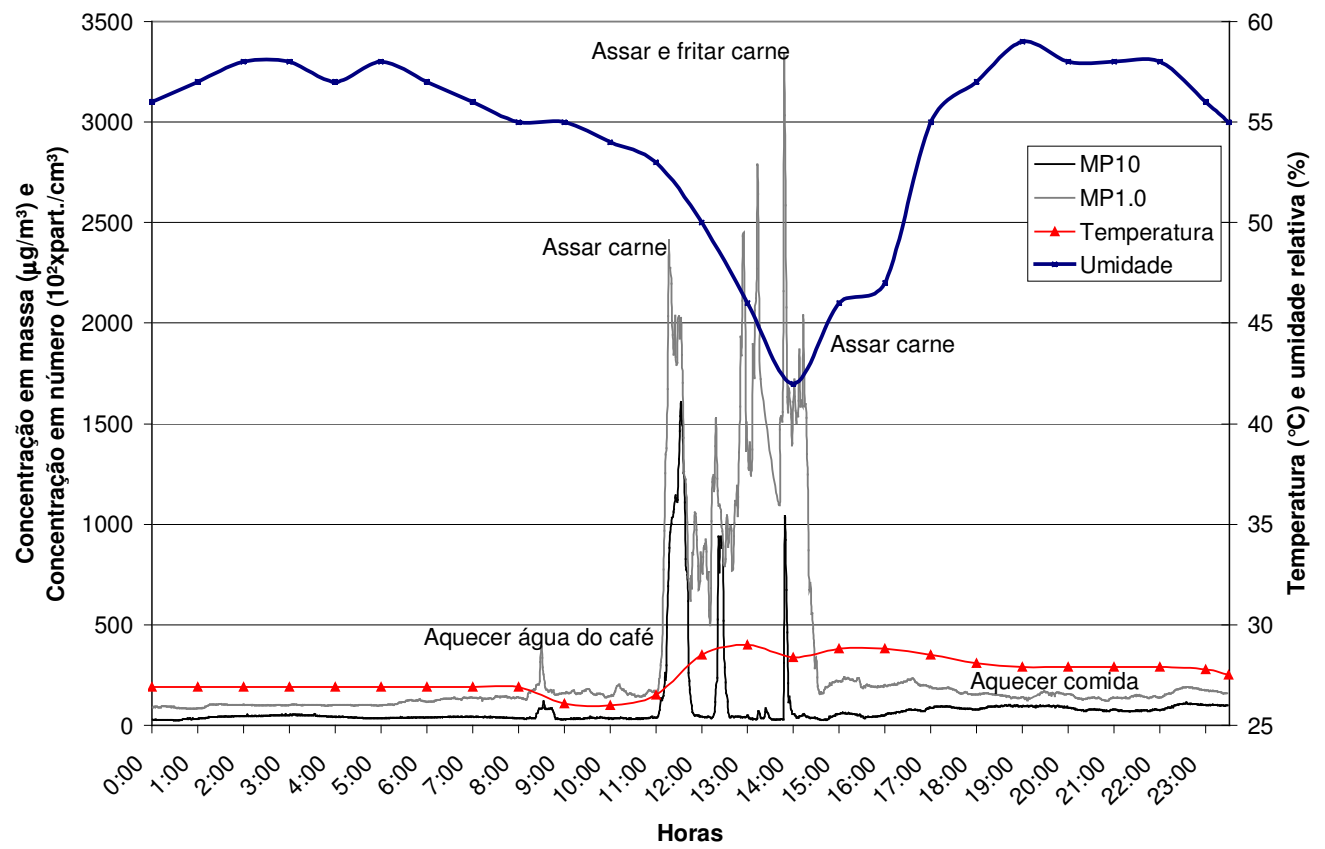

Figura 26 - Distribuição da concentração de aerodispersóide, da temperatura e da umidade relativa em vinte e quatro horas para a cozinha do apartamento $(12 / 01 / 06)$.

Os valores, na Figura 26, indicam a distribuição da concentração em massa e em número de aerodispersóides, da temperatura e da umidade relativa na cozinha do apartamento, em 12/01/2006. Às 13h48, a máxima concentração em número de aerodispersóides foi de 331.066 part./ $\mathrm{cm}^{3}$, sendo atribuído esse aumento ao fato de assar e fritar carne (ver na legenda $\mathrm{MP}_{1.0}$ ). Às $11 \mathrm{~h} 32$, a máxima concentração em massa de aerodispersóides foi de $1.609 \mu \mathrm{g} / \mathrm{m}^{3}$, igualmente atribuído para assar carne (ver na legenda $\mathrm{MP}_{10}$ ).

A temperatura e a umidade relativa tiveram comportamentos discordantes durante as atividades envolvidas no período das 11 às 15 horas. Neste período, a temperatura variou entre $26,9^{\circ} \mathrm{C}$ e $29^{\circ} \mathrm{C}$ e a umidade relativa variou entre $58 \%$ e $42 \%$, fato que foi atribuído ao acionamento do forno e de um dos queimadores do fogão.

Na Figura 27 apresentam-se as distribuições da concentração em massa e em número de aerodispersóides, da temperatura e da umidade relativa, em vinte e quatro horas, para a sala de estar do apartamento. 


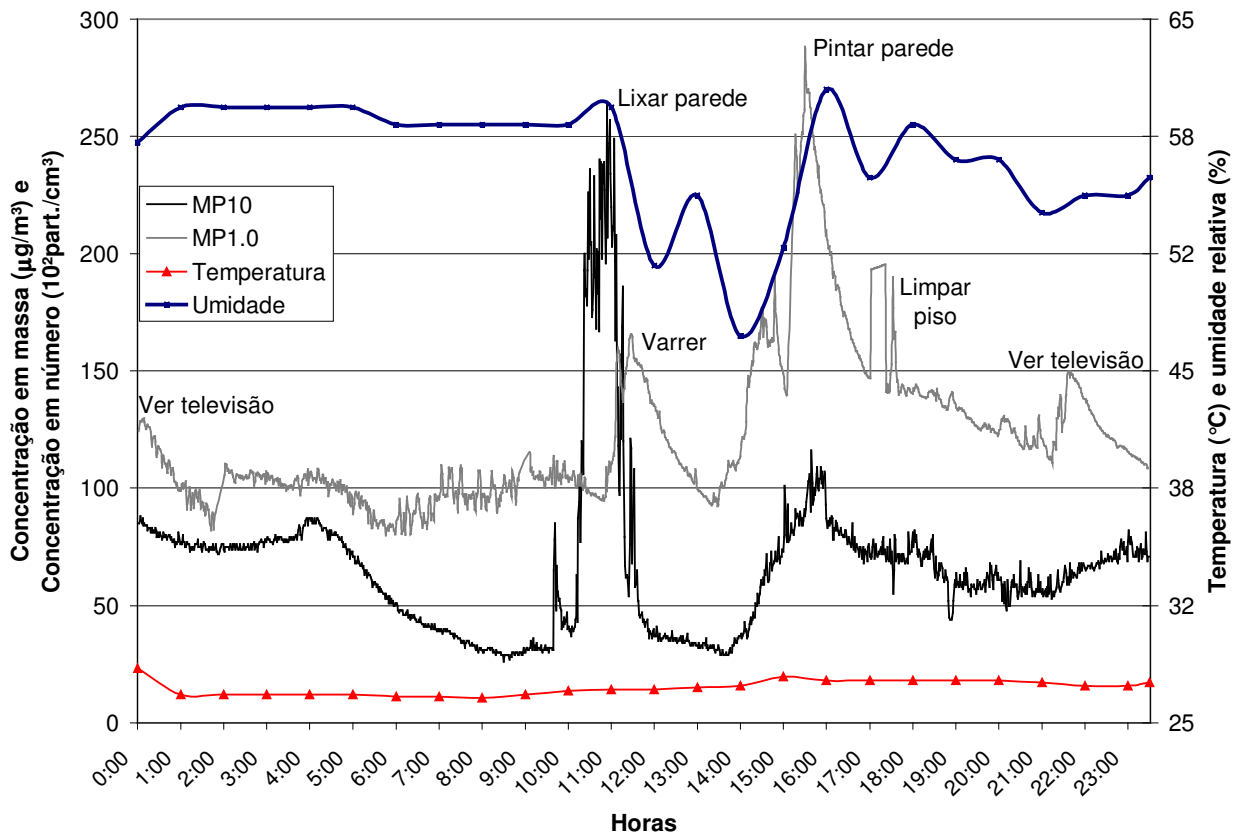

Figura 27 - Distribuição da concentração de aerodispersóide, da temperatura e da umidade relativa em vinte e quatro horas para a sala de estar do apartamento $(13 / 01 / 06)$.

Às 15h30, a máxima concentração em número de aerodispersóides foi de 28.828 part. $/ \mathrm{cm}^{3}$, sendo atribuído esse aumento ao fato de pintar parede (ver na legenda $\mathrm{MP}_{1.0}$ ). Às $10 \mathrm{~h} 53$, a máxima concentração em massa de aerodispersóides foi de 264 $\mu \mathrm{g} / \mathrm{m}^{3}$, igualmente atribuído para lixar parede (ver na legenda $\mathrm{MP}_{10}$ ).

A temperatura teve comportamento homogêneo em torno de $27^{\circ} \mathrm{C}$. A umidade relativa teve comportamento homogêneo antes e depois de lixar, varrer e pintar o hall social, ficando em torno de 58\%. Durante estes eventos, a umidade relativa variou entre 51 e $61 \%$.

Na Figura 28 apresentam-se as distribuições da concentração em massa e em número de aerodispersóides, da temperatura e da umidade relativa, em vinte e quatro horas, para a área de serviço do apartamento. 


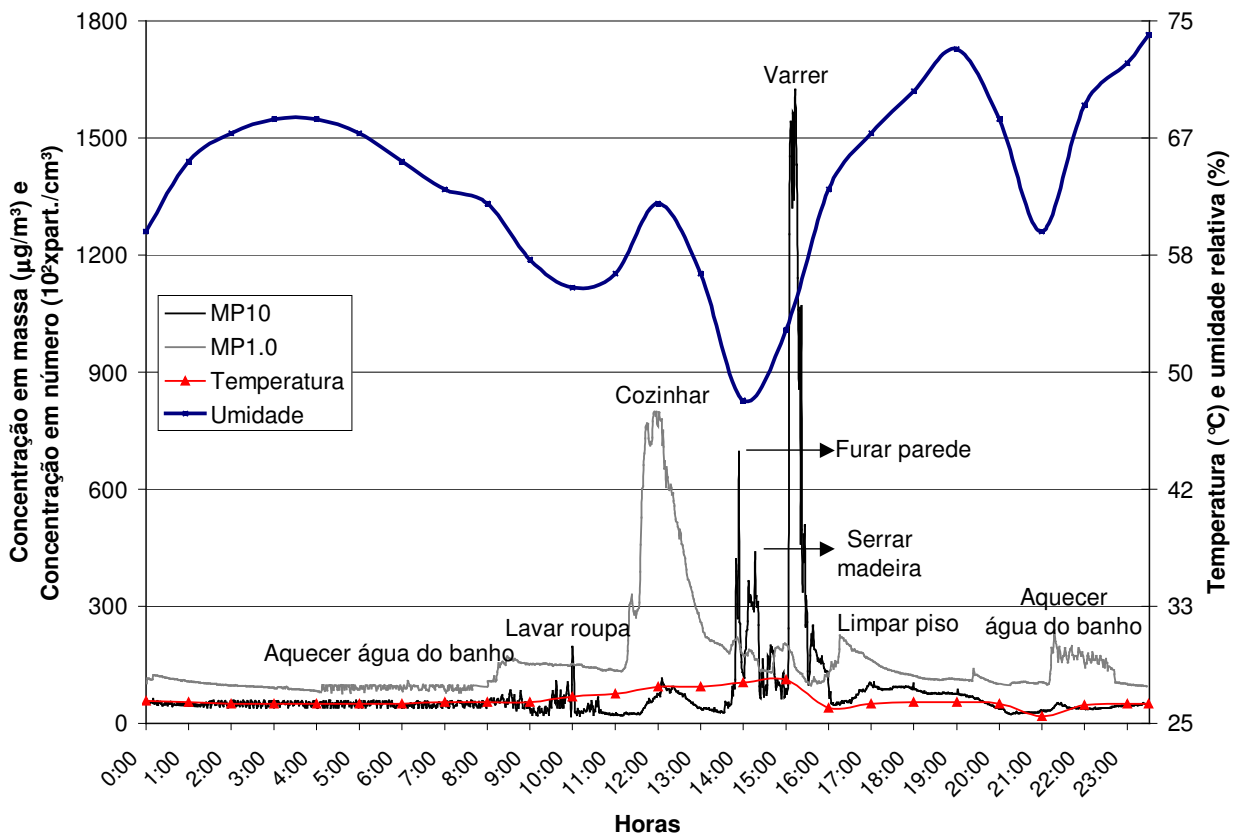

Figura 28 - Distribuição da concentração de aerodispersóide, da temperatura e da umidade relativa em vinte e quatro horas para a área de serviço do apartamento (14/01/06).

Às 11h55, a máxima concentração em número de aerodispersóides foi de 79.896 part./ $\mathrm{cm}^{3}$, sendo atribuído esse aumento ao cozimento na cozinha (ver na legenda $\left.\mathrm{MP}_{1.0}\right)$. Às $15 \mathrm{~h} 13$, a máxima concentração em massa de aerodispersóides foi de 1.624 $\mu \mathrm{g} / \mathrm{m}^{3}$, igualmente atribuído para varrer chão (ver na legenda $\mathrm{MP}_{10}$ ).

A temperatura variou entre $26,4^{\circ} \mathrm{C}$ e 28,1 , das $9 \mathrm{~h} 00$ às $15 \mathrm{~h} 00$, após este horário retornou para $26,1^{\circ} \mathrm{C}$. A umidade relativa variou entre $48 \%$ e $70 \%$ durante a limpeza do piso.

Na Figura 29 apresentam-se as distribuições da concentração em massa e em número de aerodispersóides, da temperatura e da umidade relativa, em vinte e quatro horas, para o dormitório do apartamento. 


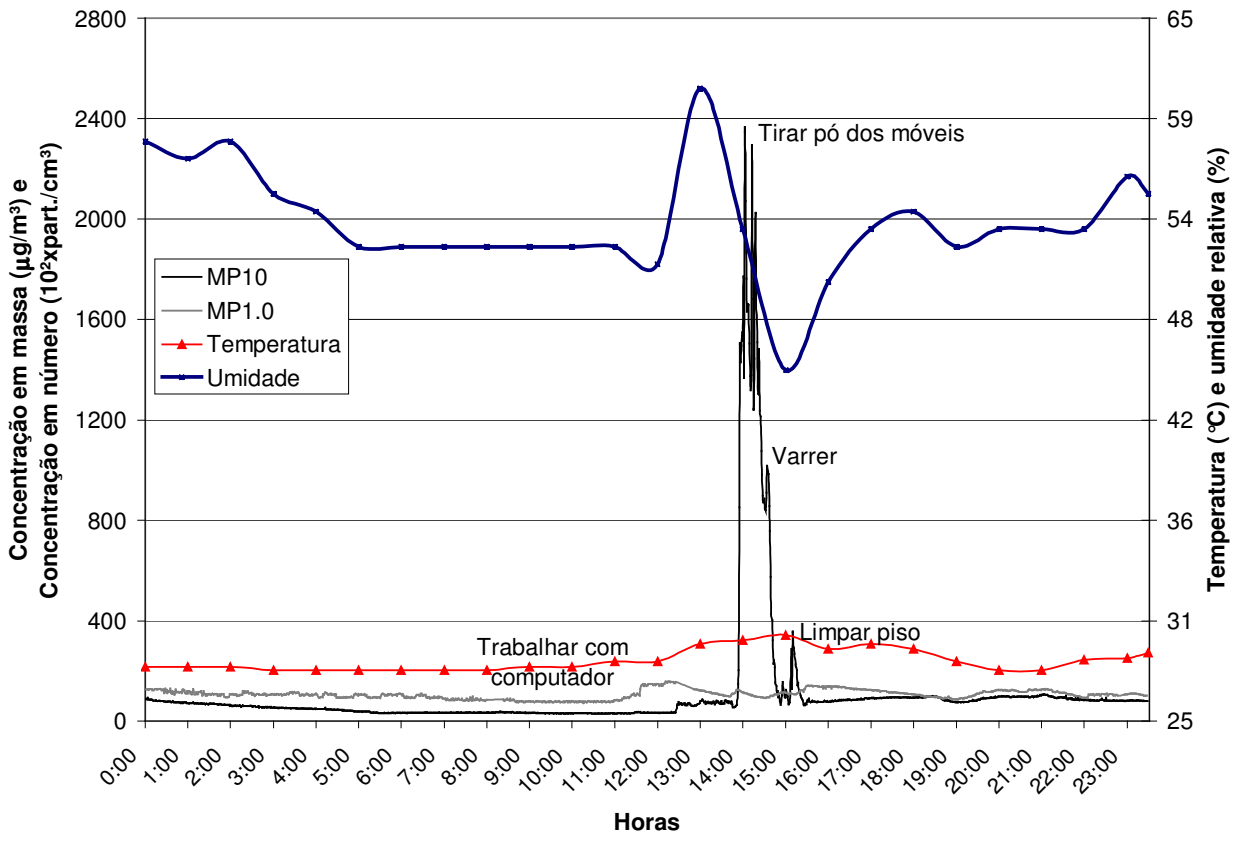

Figura 29 - Distribuição da concentração de aerodispersóide, da temperatura e da umidade relativa em vinte e quatro horas para o dormitório do apartamento $(15 / 01 / 06)$.

Às 12h14, a máxima concentração em número de aerodispersóides foi de 9.572 part./ $\mathrm{cm}^{3}$, sendo atribuído à ação de trabalhar com computador (ver na legenda $\left.\mathrm{MP}_{1.0}\right)$. Às 14h02, a máxima concentração em massa de aerodispersóides foi de 2.345 $\mu \mathrm{g} / \mathrm{m}^{3}$, igualmente atribuído para tirar pó dos móveis (ver na legenda $\mathrm{MP}_{10}$ ).

A temperatura variou entre $28,4^{\circ} \mathrm{C}$ e $29,9^{\circ} \mathrm{C}$, das $12 \mathrm{~h} 00$ às $15 \mathrm{~h} 00$. A umidade relativa variou entre $45 \%$ e $61 \%$, durante a ação de tirar pó dos móveis.

Na Figura 30 apresentam-se as distribuições da concentração em massa e em número de aerodispersóides, da temperatura e da umidade relativa, em vinte e quatro horas, para o banheiro do apartamento. 


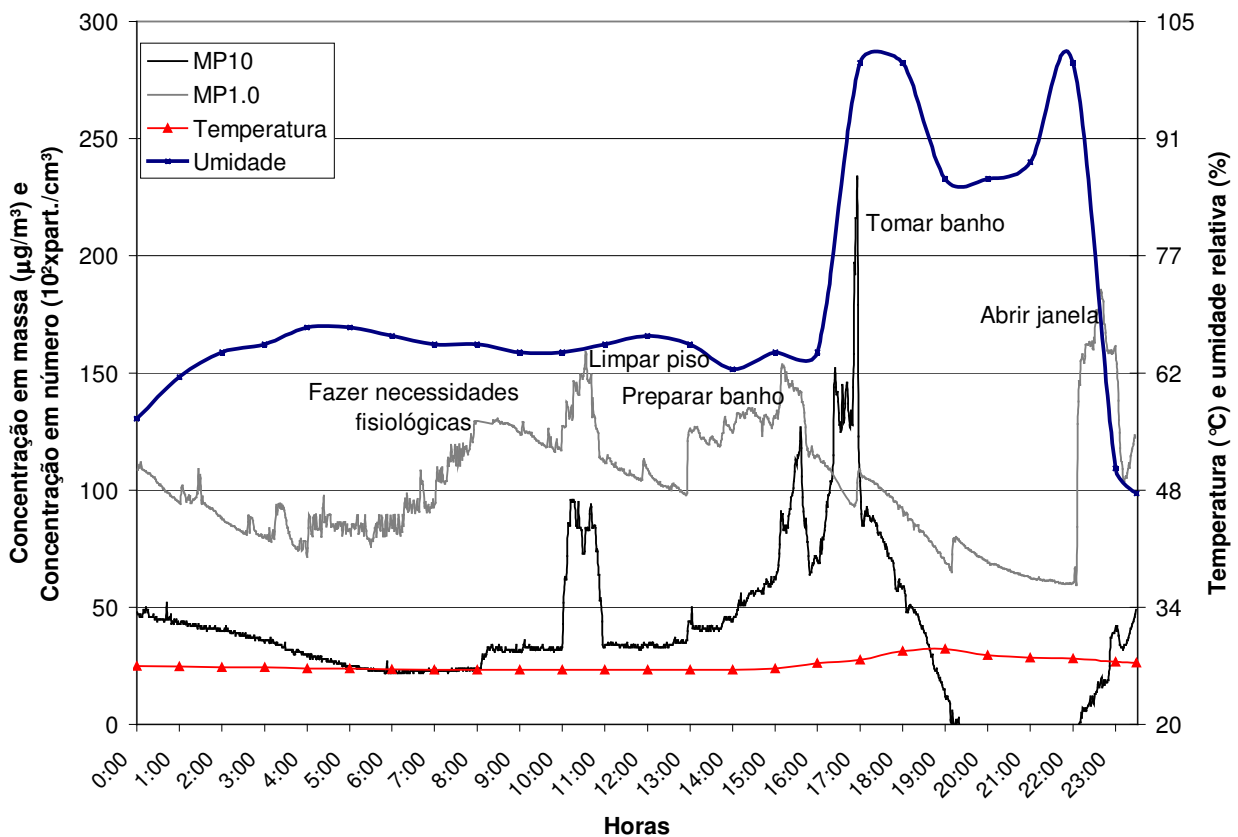

Figura 30 - Distribuição da concentração de aerodispersóide, da temperatura e da umidade relativa em vinte e quatro horas para o banheiro do apartamento $(16 / 01 / 06)$.

Às 22h40, a máxima concentração em número de aerodispersóides foi de 18.540 part. $/ \mathrm{cm}^{3}$, sendo atribuído esse aumento ao fato de abrir a janela (ver na legenda $\mathrm{MP}_{1.0}$ ). Às $16 \mathrm{~h} 55$, a máxima concentração em massa de aerodispersóides foi de 233 $\mu \mathrm{g} / \mathrm{m}^{3}$, igualmente atribuído para tomar banho, gerando vapor (ver na legenda $\mathrm{MP}_{10}$ ).

A temperatura teve comportamento homogêneo em torno de $27,2^{\circ} \mathrm{C}$. A umidade relativa chegou a picos de $100 \%$ às $17 \mathrm{~h} 00,18 \mathrm{~h} 00$ e $22 \mathrm{~h} 00$, sendo atribuído esse aumento ao fato de tomar banho.

Na Figura 31 apresentam-se as distribuições da concentração em massa e em número de aerodispersóides, da temperatura e da umidade relativa, em vinte e quatro horas, para a sala de estar do apartamento. 


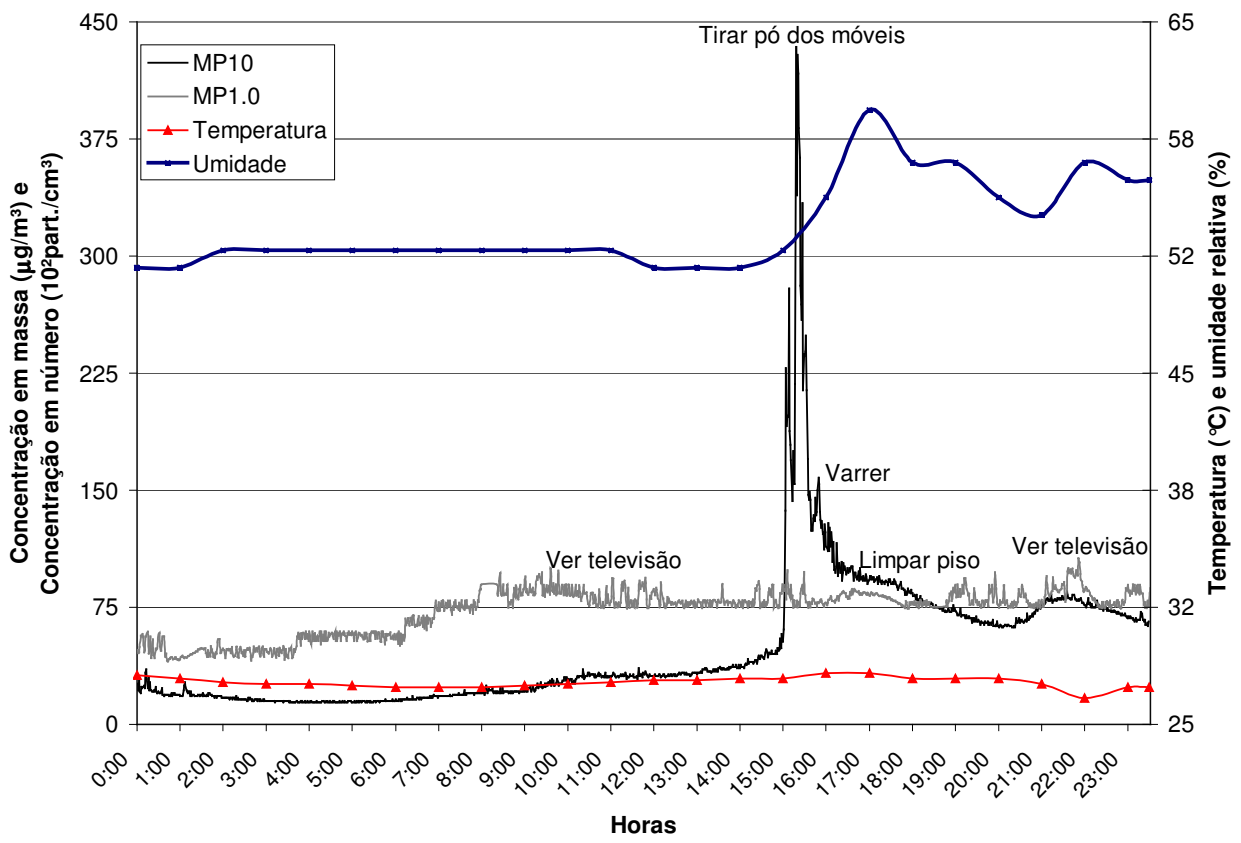

Figura 31 - Distribuição da concentração de aerodispersóide, da temperatura e da umidade relativa em vinte e quatro horas para a sala de estar do apartamento $(18 / 01 / 06)$.

Às 21h51, a máxima concentração em número de aerodispersóides foi de 10.637 part./ $\mathrm{cm}^{3}$, sendo atribuído esse aumento ao fato de ver televisão (ver na legenda $\mathrm{MP}_{1.0}$ ). Às $15 \mathrm{~h} 17$, a máxima concentração em massa de aerodispersóides foi de 434 $\mu \mathrm{g} / \mathrm{m}^{3}$, igualmente atribuído para tirar pó dos móveis (ver na legenda $\mathrm{MP}_{10}$ ).

A temperatura teve comportamento homogêneo em torno de $27,4^{\circ} \mathrm{C}$. A umidade relativa variou entre $51 \%$ e $60 \%$, sendo atribuído esse aumento à limpeza da sala.

Em seguida, na Figura 32, apresentam-se as porcentagens do tempo de medição em que a concentração média em massa de aerodispersóides ficou acima de $80 \mu \mathrm{g} / \mathrm{m}^{3}$, para as atividades realizadas no apartamento, sendo utilizada a equação da média aritmética para calcular as concentrações em massa de aerodispersóides. 


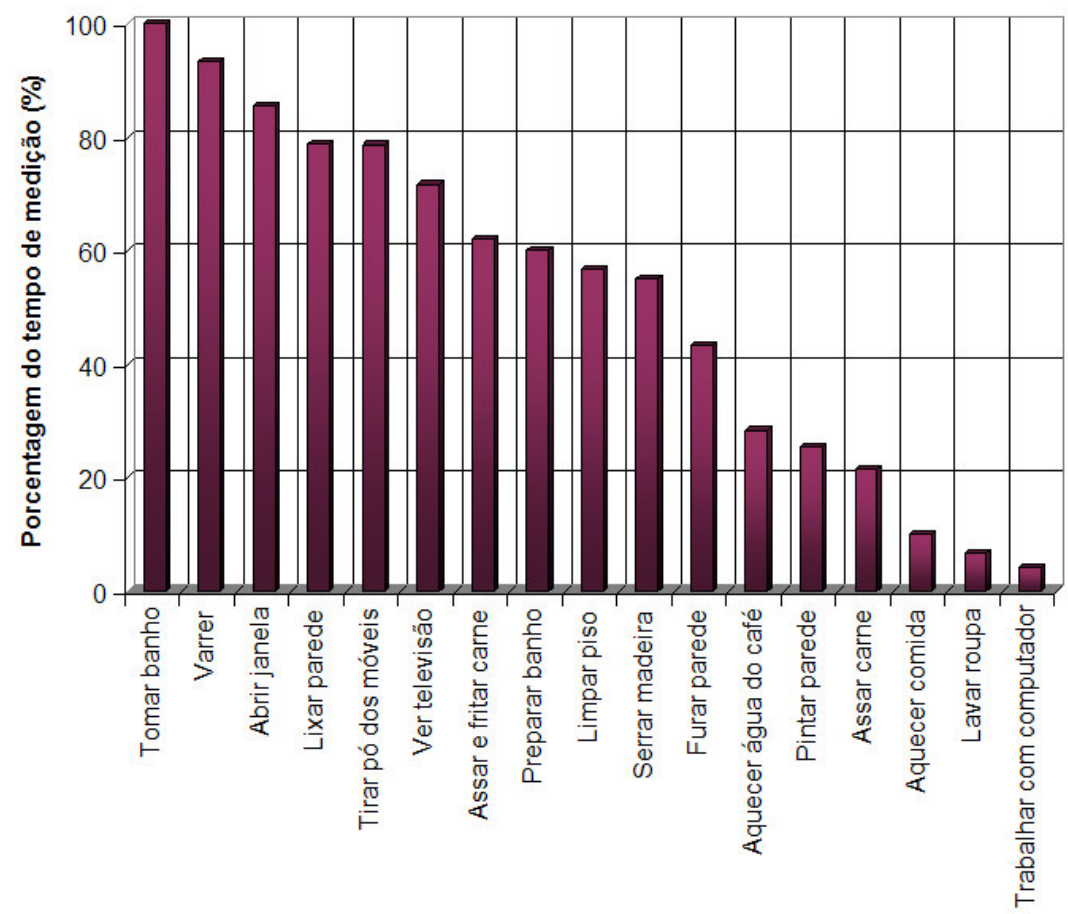

Figura 32 - Porcentagens do tempo de medição em que a concentração média em massa de aerodispersóides ficou acima de $80 \mu \mathrm{g} / \mathrm{m}^{3}$, para as atividades realizadas no apartamento.

Observa-se, na Figura 32, que a porcentagem do tempo de medição da concentração média em massa de aerodispersóides acima de $80 \mu \mathrm{g} / \mathrm{m}^{3}$ foi de: $100 \%$ atribuído ao fato de tomar banho, $93 \%$ atribuído ao fato de varrer, $85 \%$ atribuído ao fato de abrir janela, 79\% atribuído ao fato de lixar parede e tirar pó dos móveis, 72\% atribuído ao fato de ver televisão, $62 \%$ atribuído ao fato de assar e fritar carne, $60 \%$ atribuído ao fato de preparar banho, $57 \%$ atribuído ao fato de limpar piso, $55 \%$ atribuído ao fato de serrar madeira, $43 \%$ atribuído ao fato de furar parede. Para as demais atividades, as porcentagens obtidas foram inferiores a $25 \%$.

A seguir, na Figura 33, apresentam-se as porcentagens do tempo de permanência das pessoas, entre 0 e 15 anos, 16 e 25 anos, e maior que 26 anos, para os ambientes internos do apartamento, como: cozinha, sala, área de serviço, dormitório e banheiro. 


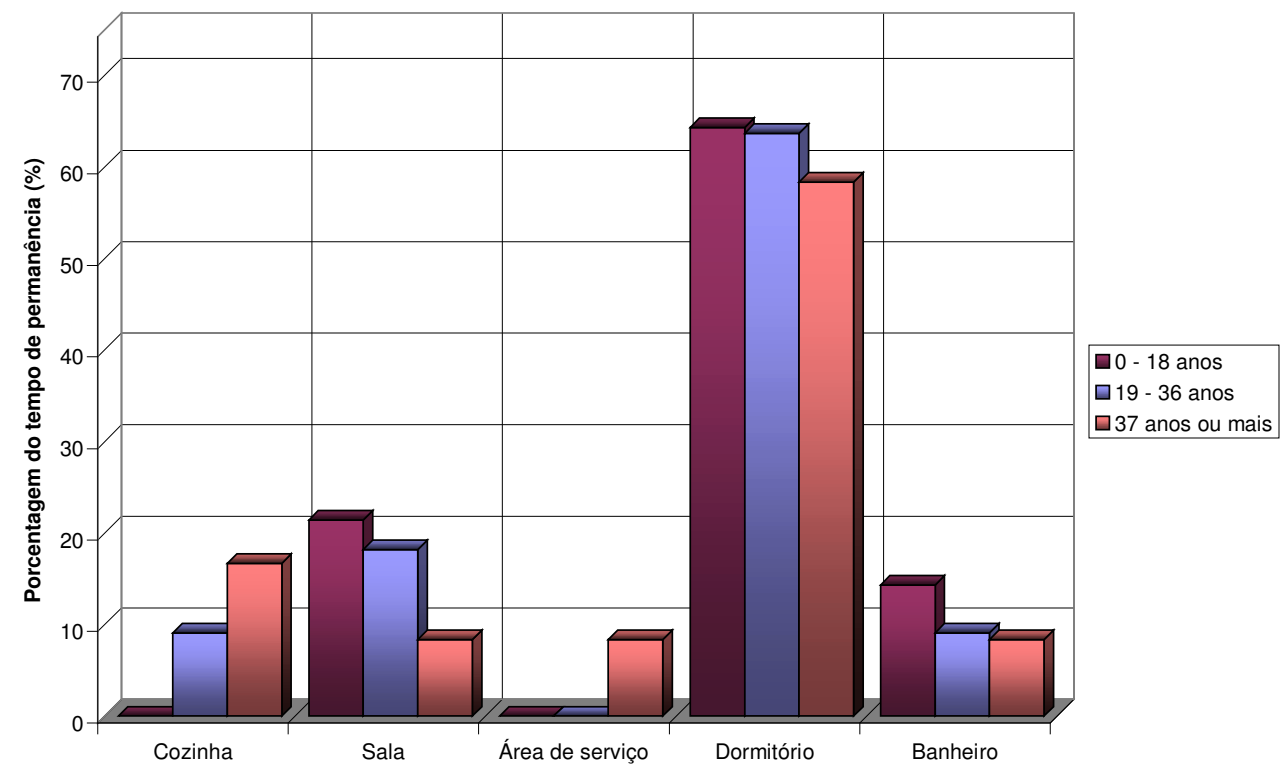

Figura 33 - Tempo de permanência das pessoas nos ambientes do apartamento.

Na Figura 33 observa-se que a médias aritmética do tempo de permanecia foi de: $62 \%$ no dormitório, $16 \%$ na sala, $11 \%$ no banheiro, $9 \%$ na cozinha e $3 \%$ na área de serviço. Portanto, segundo Adgate et al., 2002, entre os 79,63\% do tempo de permanência das pessoas nas residências ou nos apartamentos, $62 \%$ deste tempo as pessoas permanecem no dormitório.

As porcentagens do tempo de medição da concentração média em massa de aerodispersóides acima de $80 \mu \mathrm{g} / \mathrm{m}^{3}$ e de permanência das pessoas no dormitório indicam valores elevados, como apresentados nos gráficos anteriores. Portanto, os valores da concentração e do tempo de permanência elevados estabelecem prejuízos a saúde dos usuários.

Em seguida, na Figura 34, apresentam-se as porcentagens acumuladas do tempo que a concentração média em massa de aerodispersóides ficou entre 0 e $80 \mu \mathrm{g} / \mathrm{m}^{3}, 81$ e $600 \mu \mathrm{g} / \mathrm{m}^{3}, 601$ e $1.120 \mu \mathrm{g} / \mathrm{m}^{3}$, e maior que $1.121 \mu \mathrm{g} / \mathrm{m}^{3}$. Os valores da concentração média em massa foram analisados estatisticamente pelas medidas de posição, 
obtendo o desvio padrão de $460 \mu \mathrm{g} / \mathrm{m}^{3}$, a variância de $211.906 \mu \mathrm{g}^{2} / \mathrm{m}$, o valor médio de $842 \mu \mathrm{g} / \mathrm{m}^{3}$ e o coeficiente de variação de $55 \%$.

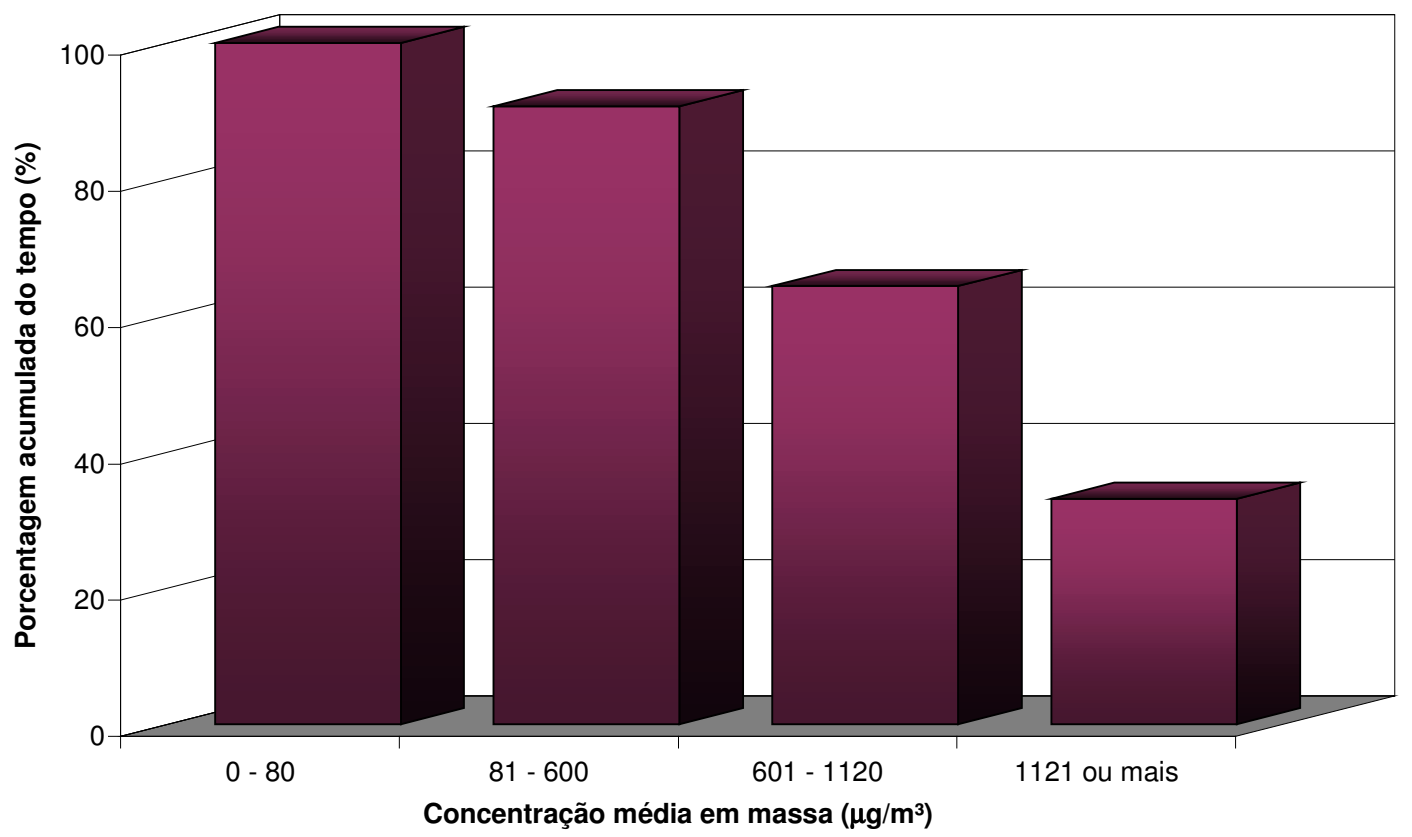

Figura 34 - Porcentagens acumuladas do tempo que a concentração média em massa de aerodispersóides ficou entre 0 e $80 \mu \mathrm{g} / \mathrm{m}^{3}, 81$ e $600 \mu \mathrm{g} / \mathrm{m}^{3}, 601$ e $1.120 \mu \mathrm{g} / \mathrm{m}^{3}$, e maior que $1.121 \mu \mathrm{g} / \mathrm{m}^{3}$.

Na Figura 34 observam-se as porcentagens acumuladas do tempo da concentração média em massa de $100 \%$ entre 0 e $80 \mu \mathrm{g} / \mathrm{m}^{3}, 91 \%$ entre 81 e $600 \mu \mathrm{g} / \mathrm{m}^{3}, 64 \%$ entre 601 e $1.120 \mu \mathrm{g} / \mathrm{m}^{3}$, e $33 \%$ maior que $1.121 \mu \mathrm{g} / \mathrm{m}$.

As porcentagens do tempo de medição da concentração média em número de aerodispersóides acima de 7.400 part./ $\mathrm{cm}^{3}$ foram de $100 \%$, para todas as atividades realizadas no apartamento.

A seguir, na Figura 35, apresentam-se as porcentagens acumuladas do tempo que a concentração média em número de aerodispersóides ficou entre 0 e $7,4 \times 10^{3}$ part./ $/ \mathrm{cm}^{3}$, entre 7,5 e $60 \times 10^{3}$ part. $/ \mathrm{cm}^{3}$, entre 60,1 e $112 \times 10^{3}$ part./$/ \mathrm{cm}^{3}$, e maior que $112,1 \times 10^{3}$ part./ $\mathrm{cm}^{3}$. Os valores da concentração média em número foram analisados 
estatisticamente pelas medidas de posição, obtendo o desvio padrão de 43.313 part. $/ \mathrm{cm}^{3}$, a variância de 1.876 .041 part. ${ }^{2} / \mathrm{cm}$, o valor médio de 88.213 part. $/ \mathrm{cm}^{3}$ e o coeficiente de variação de $49 \%$.

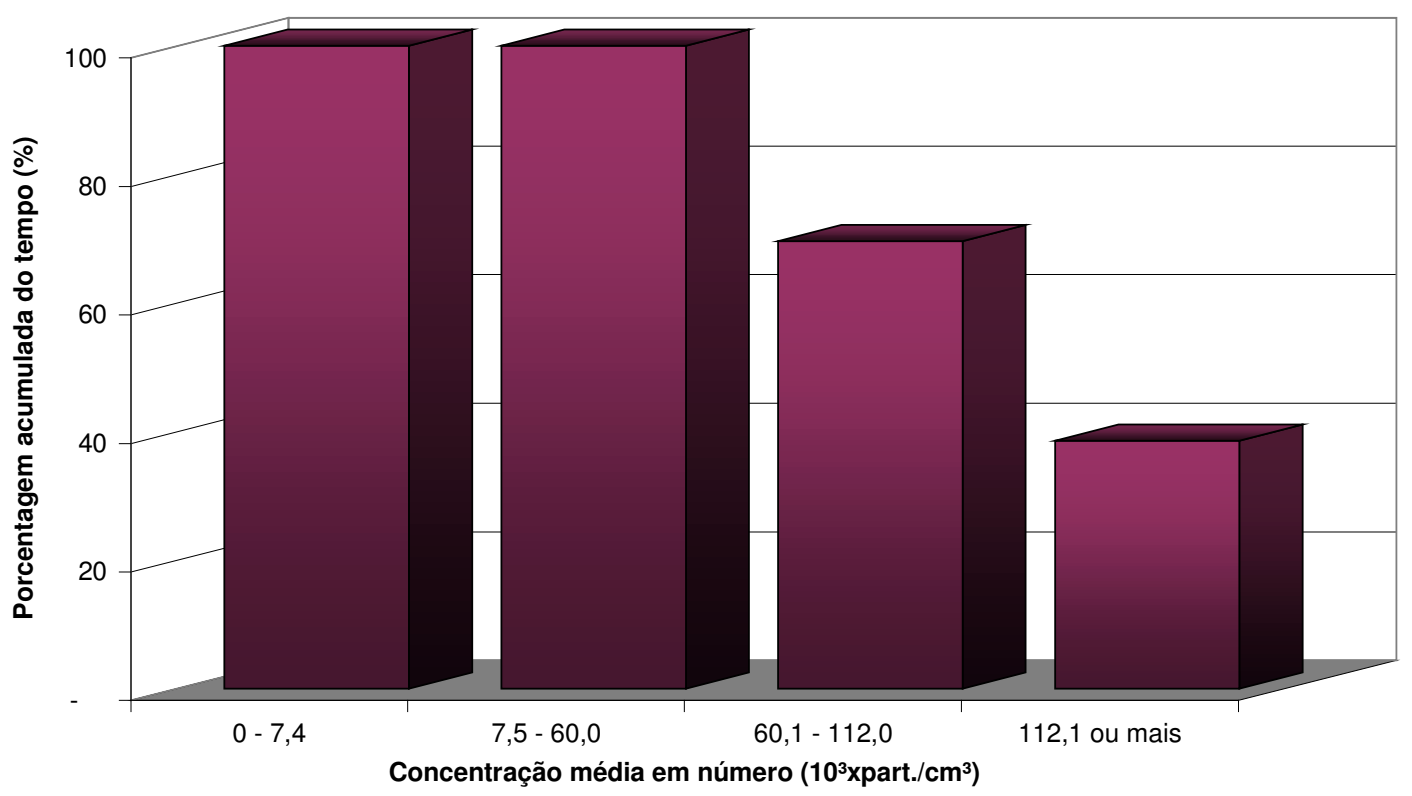

Figura 35 - Porcentagens acumuladas do tempo que a concentração média em número de aerodispersóides ficou entre 0 e $7,4 \times 10^{3}$ part./$/ \mathrm{cm}^{3}$, entre 7,5 e $60 \times 10^{3} \mathrm{part} . / \mathrm{cm}^{3}$, entre 60,1 e $112 \times 10^{3}$ part./ $\mathrm{cm}^{3}$, e maior que $112,1 \times 10^{3}$ part. $/ \mathrm{cm}^{3}$.

Na Figura 35 observam-se as porcentagens acumuladas do tempo da concentração média em número de $100 \%$ entre 0 e $60 \times 10^{3}$ part. $/ \mathrm{cm}^{3}, 70 \%$ entre 60,1 e $112 \times 10^{3}$ part. $/ \mathrm{cm}^{3}$, e $39 \%$ maior que $112,1 \times 10^{3}$ part./ $\mathrm{cm}^{3}$. Nas duas primeiras faixas, as porcentagens acumuladas do tempo foram de $100 \%$.

A seguir, na Figura 36, apresenta-se a correlação entre a concentração externa (dados obtidos pela CETESB) e interna em massa de aerodispersóides no apartamento. Observa-se que o valor de $\mathrm{R}^{2}$ é igual a 0,32 , indicando que a correlação entre estas concentrações é baixa. 
$\mathrm{Na}$ qualidade do ar interno a preocupação quanto à origem dos poluentes é fundamental para minimizar as emissões, garantindo a saúde e bem estar dos usuários nos edifícios.

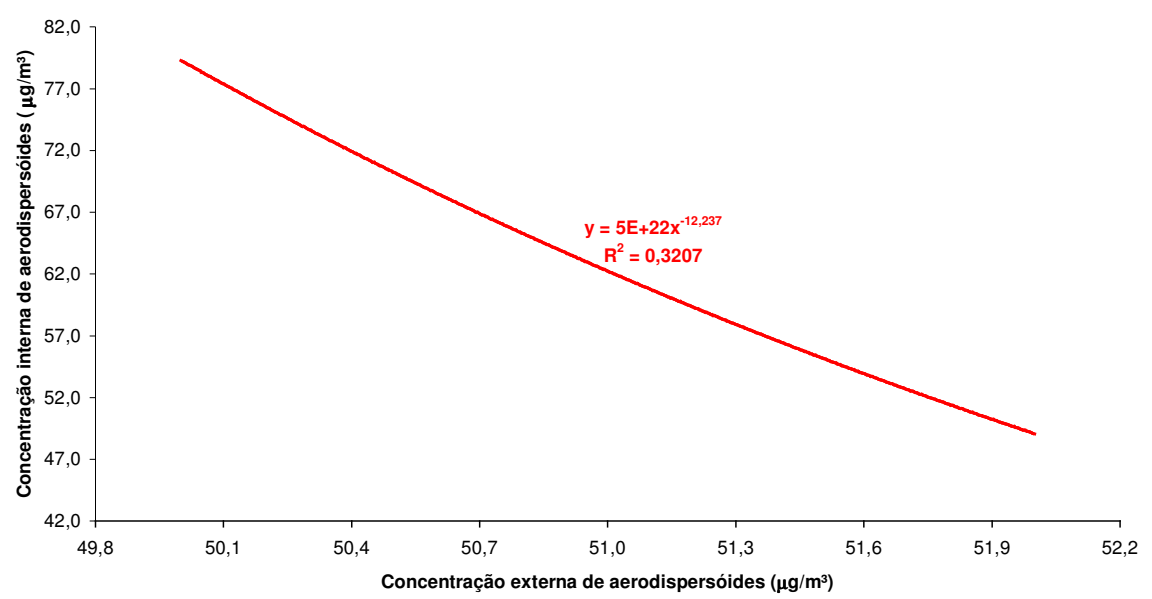

Figura 36 - Correlação entre a concentração interna e externa em massa de aerodispersóides no apartamento.

Na Figura 37 apresenta-se a correlação entre a umidade relativa interna e a concentração interna em número de aerodispersóides no apartamento.

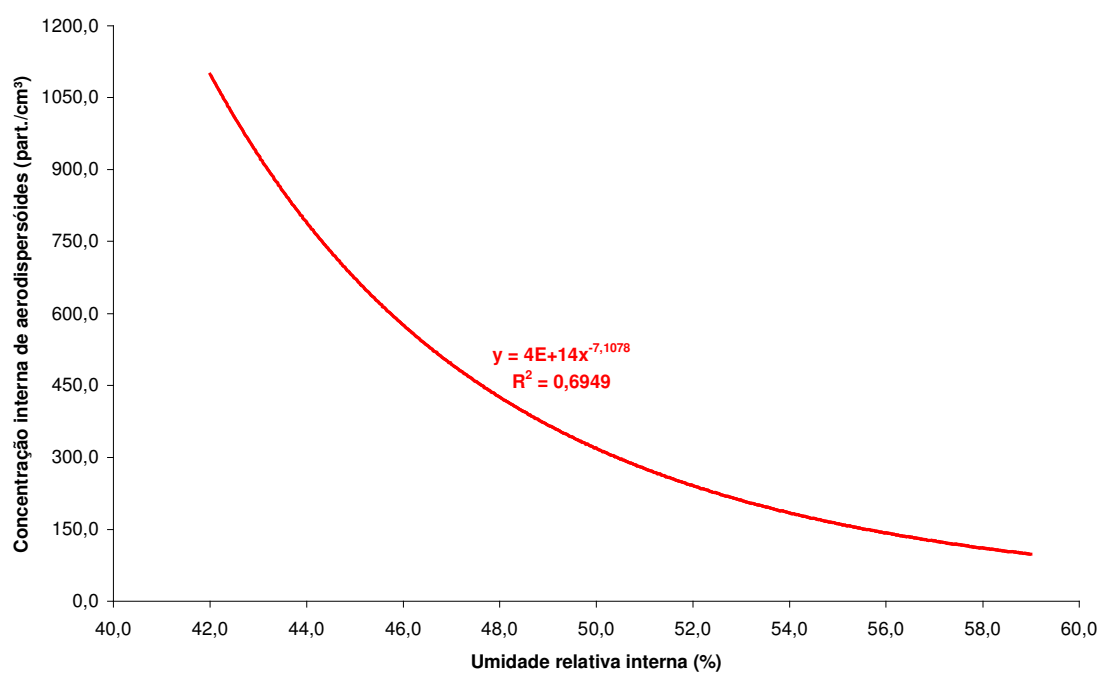

Figura 37 - Correlação entre a concentração interna em número de aerodispersóides e a umidade relativa interna no apartamento. 
Observa-se que, na Figura 37, quanto maior a umidade relativa interna, menor é a concentração interna em número de aerodispersóides. Porém, a umidade relativa interna não pode ser confundida com outro tipo de material particulado.

Em seguida, na Figura 38, apresenta-se a correlação entre a temperatura interna e a concentração interna em número de aerodispersóides no apartamento.

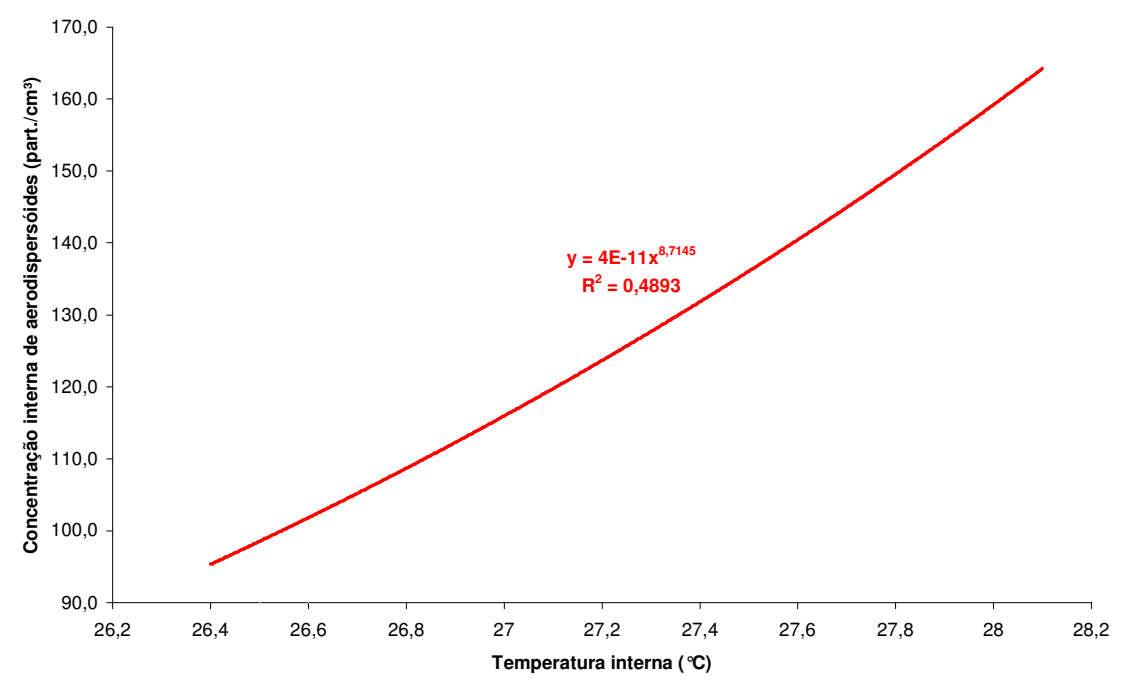

Figura 38 - Correlação entre a concentração interna em número de aerodispersóides e a temperatura interna no apartamento.

Observa-se que, na Figura 38, quanto maior a temperatura interna, maior é a concentração interna em número de aerodispersóides. Portanto, quanto mais seco o ar externo maior será a quantidade de material particulado na atmosfera.

\subsection{Análise dos Resultados}

A análise dos resultados das concentrações de aerodispersóides está fundamentada sob alguns aspectos relativos à interface com o ambiente externo, o ambiente interno e o projeto, bem como das condições requeridas pelos usuários. Estes aspectos são apresentados a seguir: 
Interface com o ambiente externo:

- Principais fontes poluidoras do ar externo.

A identificação das principais fontes poluidoras do ar externo, como o tráfego de automóveis a gasolina, álcool ou diesel, os locais de estacionamento ou de manobras de veículos e a fumaça das fábricas, permitiu verificar a influência destas fontes na qualidade do ar interno. Nos resultados da pesquisa observou-se que a concentração de aerodispersóides foi maior em ambientes internos próximos às vias principais, como Via Anchieta (Residência 2 e Clínica Médica 1 e 2) e Marginal Pinheiros (Apartamento 3). Nas atividades humanas durante a $2^{\mathrm{a}}$ fase, distantes das vias expressas, a concentração interna $\left(842 \mu \mathrm{g} / \mathrm{m}^{3}\right)$ foi vinte vezes maior do que a externa $\left(42 \mu \mathrm{g} / \mathrm{m}^{3}\right)$.

- Condições climáticas externas.

A análise desse aspecto permitiu dizer se a temperatura e umidade relativa externa foram próximas às internas, verificando a sua influência sobre as condições de temperatura e umidade relativa interna. A pesquisa indicou que a temperatura externa média $\left(19^{\circ} \mathrm{C}\right)$ foi próxima à interna $\left(20,4^{\circ} \mathrm{C}\right)$, porém a umidade relativa externa $(78 \%)$ foi maior do que a interna $(50 \%)$.

- Qualidade do ar atmosférico local.

O objetivo foi determinar a qualidade do ar atmosférico local, para comparar com a qualidade do ar interno. Os dados mostraram que a concentração média de aerodispersóides externa foi maior do que a interna, durante a estação seca, principalmente no mês de agosto. Nas atividades domésticas ocupacionais a concentração interna foi duas a três vezes maior do que a externa. 
- Velocidade de vento.

Este aspecto foi analisado, conforme relatório da CETESB (2004), se a ventilação natural pode ser considerada eficientemente, de acordo com os padrões normativos. Durante o período seco de amostragem, as condições de dispersão foram desfavoráveis, devido à formação dos anticiclones, influenciados pela inversão térmica, aumentando a concentração de poluente no ar.

- Infiltração de água ou de ar.

Pretendeu-se verificar a interferência da infiltração de água ou de ar na concentração de aerodispersóides em ambientes internos à edificação. Não houve problema de umidade nos ambientes. As aberturas e suas disposições influíram na concentração em massa e em número de aerodispersóides, sendo atribuída essa relação ao fato de haver ventilação natural ou condicionamento de ar.

- Localização do duto de entrada de ar.

Verificou nos locais de estudo quanto à localização do duto de entrada de ar, identificando se estavam próximos de estacionamento, área de manobra, vegetação, fontes de poluição, entre outros aspectos. Nos edifícios com condicionamento de ar os dutos estavam localizados distantes das fontes de emissão de poluente.

Interface com o ambiente interno:

- Temperatura e umidade relativa interna.

O objetivo foi identificar a temperatura e a umidade relativa interna, de modo que sejam comparadas com a concentração em massa e em número de aerodispersóides. Observou-se que quanto menor a concentração de aerodispersóides, menor seria a temperatura e maior seria a umidade relativa interna. 
- Concentração em massa e em número de aerodispersóides.

Este aspecto pretendeu identificar as concentrações em massa e em número de aerodispersóides, por meio de medições usando equipamentos específicos para cada caso. $\mathrm{Na} 1^{\mathrm{a}}$ fase desta pesquisa, a concentração média em massa foi de $95 \mu \mathrm{g} / \mathrm{m}^{3}$, sendo $25 \%$ do tempo entre 81 e $100 \mu \mathrm{g} / \mathrm{m}^{3}$, e a concentração média em número foi de 10.675 part. $/ \mathrm{cm}^{3}$, sendo $66 \%$ do tempo entre 7.500 e 10.000 part. $/ \mathrm{cm}^{3}$. Na $2^{\mathrm{a}}$ fase desta pesquisa, a concentração média em massa foi de $842 \mu \mathrm{g} / \mathrm{m}^{3}$, sendo $91 \%$ do tempo entre 81 e $600 \mu \mathrm{g} / \mathrm{m}^{3}$, e a concentração média em número foi de 88.213 part./ $\mathrm{cm}^{3}$, sendo $60 \%$ do tempo entre 60.100 e 112.000 part. $/ \mathrm{cm}^{3}$.

- Principais fontes poluidoras do ar interno.

A análise desse aspecto permitiu dizer se as concentrações em massa e em número de aerodispersóides estavam relacionados com as fontes de emissão do ar interno. Da $1^{\text {a }}$ fase da pesquisa (edifícios diversos), para a $2^{\circ}$ fase (apartamento modelo), as concentrações indicaram que as atividades humanas domésticas foram responsáveis pela maior emissão e ressuspensão dos aerodispersóides do que o envelhecimento natural dos materiais, reação fotoquímica, umidade, produtos químicos e interação entre eles; pois as concentrações foram maiores na segunda fase da pesquisa.

\section{Interface com o projeto:}

- Área útil e posição do edifício.

A identificação da área útil e da posição do edifício no terreno para utilização nas análises das concentrações em massa e em número de aerodispersóides internos. Nos estudos os edifícios ocupavam em torno de $85 \%$ do terreno e localizavam próximo ao centro dos mesmos. 
- Quantidade e dimensão das portas e das janelas.

Pretendeu verificar a quantidade de portas e de janelas e suas dimensões para análise das concentrações em massa e em número de aerodispersóides. Nos estudos da $2^{\mathrm{a}}$ fase (apartamento) verificou-se que a quantidade e a dimensão de portas e de janelas permitiram maior ou menor ventilação diluidora, diminuindo ou aumentando as concentrações de aerodispersóides nos ambientes.

- Sistema de ventilação e de climatização.

Este aspecto pretendeu identificar os sistemas de ventilação natural ou de condicionamento de ar nos edifícios. Observou-se também que nos ambientes com sistema de ventilação natural, a concentração média de aerodispersóides foi em geral maior do que nos ambientes com sistema de condicionamento de ar.

- Proteção externa contra os poluentes.

Identificou-se na área externa do edifício, se havia proteção contra os poluentes externos, como muro, cerca viva ou outra barreira que impeça a contaminação do ar interno. Em nenhum edifício houve barreiras contra os poluentes do ar, como por exemplo, vegetação, brise-soleil e muro, entre outros.

Interface com o usuário:

- Características dos ocupantes (idade, doenças, etc.).

Verificou-se quanto as características da idade, doenças, sintomas, etc. Observou-se que todos os usuários estavam na idade adulta, com exceção da clínica médica. Quanto às doenças e aos sintomas, os principais problemas encontrados foram nos aparelhos respiratório e circulatório (TSE et al., 2004). 
- Taxa de ocupação e tipos de atividades.

O objetivo foi identificar a taxa de ocupação e os tipos de atividades internas com relação aos ambientes internos. Observou-se que as concentrações médias em massa e em número de aerodispersóides, durante as atividades humanas domésticas (cozimento, reforma, limpeza, entre outras), foram várias vezes maior do que as concentrações com atividades humanas profissionais ou em ambientes com menor ocupação durante o dia.

\subsection{Discussão dos Resultados Quantitativos}

A seguir apresentam-se os estudos de He et al. (2004), Chao e Wong (2002), Zhao et al. (2004) e $\mathrm{Na}$ et al. (2004), para os aerodispersóides presentes nos ambientes internos.

Segundo He et al. (2004), as condições de ventilação, normal ou mínima, respectivamente janelas abertas e fechadas, podem influenciar a concentração em massa e em número de aerodispersóides em um ambiente interno. Em seus estudos, para medir a concentração em massa de aerodispersóides finos, o equipamento utilizado foi: Dust Trak Aerosol Monitor, o mesmo equipamento desta pesquisa. Para medir a concentração em número de aerodispersóides ultrafinos, finos e grossos, os equipamentos foram: Scanning Mobility Particle Sizer-SMPS e Aerodynamic Particle Sizer-APS, para contar, respectivamente, partículas entre 0,015 e 0,685 $\mu \mathrm{m}$, e entre 0,5 e $20 \mu \mathrm{m}$.

A seguir, na Figura 39, apresentam-se os resultados de He et al. (2004), com as distribuições da concentração em massa de aerodispersóides finos $\left(\mathrm{PM}_{2,5}\right)$ e em número de aerodispersóides ultrafinos, finos e grossos $\left(\mathrm{PM}_{0,1}, \mathrm{PM}_{2,5}\right.$ e $\left.\mathrm{PM}_{10}\right)$, para uma residência com ventilação mínima. 


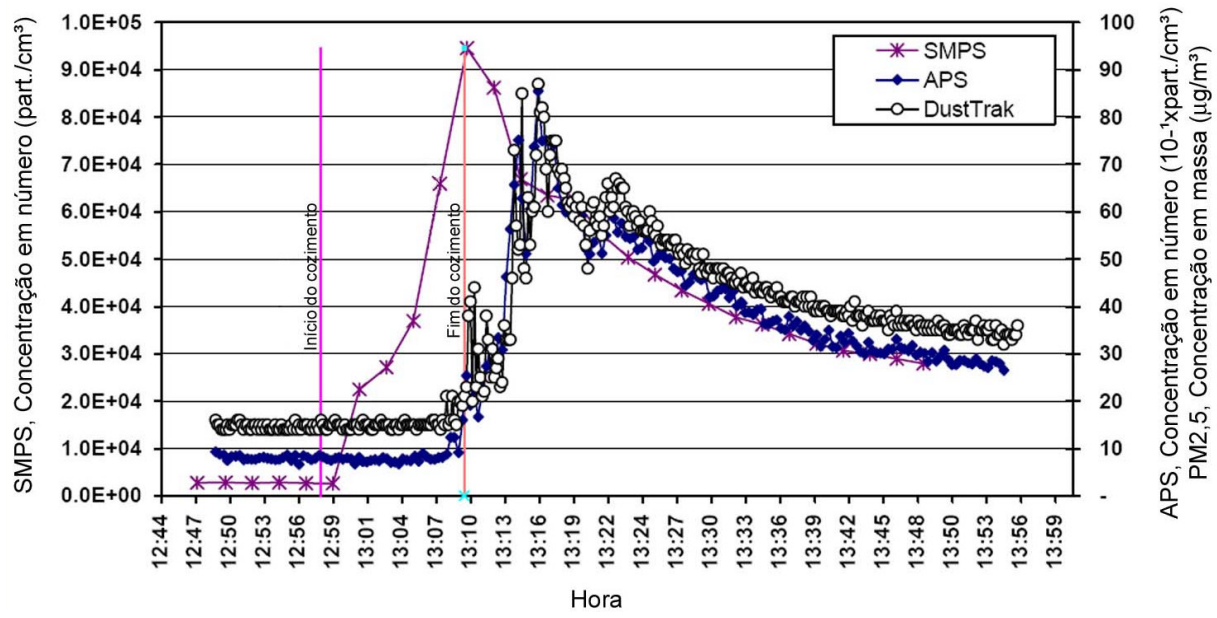

Figura 39 - Distribuições da concentração em massa $\left(\mathbf{P M}_{2,5}\right)$ e em número (SMPS e APS) de aerodispersóides para uma residência com ventilação mínima; antes, durante e após teste de cozimento. Fonte: He et al. (2004).

Segundo o gráfico da Figura 39, as concentrações de aerodispersóides não retornaram às condições iniciais após 45 minutos do teste de cozimento, devido ao ambiente estar com as janelas fechadas, caracterizada pela ventilação mínima.

$\mathrm{Na}$ Figura 40, apresentam-se as distribuições da concentração em massa de aerodispersóides finos $\left(\mathrm{PM}_{2,5}\right)$ e em número de aerodispersóides ultrafinos, finos e grossos $\left(\mathrm{PM}_{0,1}, \mathrm{PM}_{2,5}\right.$ e $\left.\mathrm{PM}_{10}\right)$, para uma residência com ventilação normal, segundo He at al. (2004). 


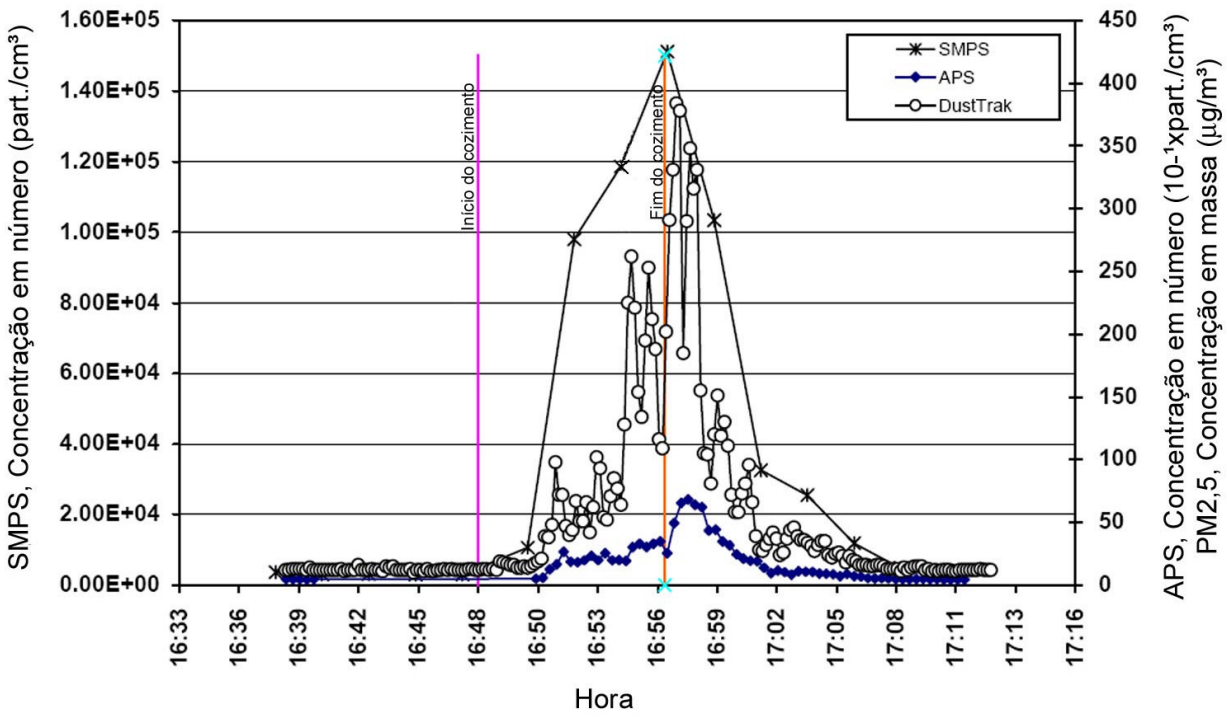

Figura 40 - Distribuições da concentração em massa $\left(\mathbf{P M}_{2,5}\right)$ e em número (SMPS e APS) de aerodispersóides para uma residência com ventilação normal; antes, durante e após teste de cozimento. Fonte: He et al. (2004).

Observa-se, na Figura 40, que as concentrações de aerodispersóides retornaram às condições iniciais após 15 minutos do teste de cozimento, devido ao ambiente estar com as janelas abertas, caracterizada pela ventilação normal.

Em ambientes internos com atividades de cozimento, pintura, limpeza, entre outros, as concentrações médias de aerodispersóides serão menores com ventilação normal do que com ventilação mínima. Igualmente atribuído ao fato de ligar o exaustor, como observado no Capítulo 3, assim como o uso de ar-condicionado e outros mecanismos de ventilação diluidora.

Zhao et al. (2004) observaram que o tipo de ventilação, cruzada ou não, podem influenciar ainda mais as concentrações de aerodispersóides em um ambiente interno. Segundo os mesmos autores, na ventilação cruzada, o ar é deslocado de um lugar para outro. $\mathrm{Na}$ ventilação não cruzada, o ar é primeiramente misturado em um ambiente e depois deslocado deste lugar para outro, conforme os diagramas de velocidade do ar apresentados na Figura 41. 

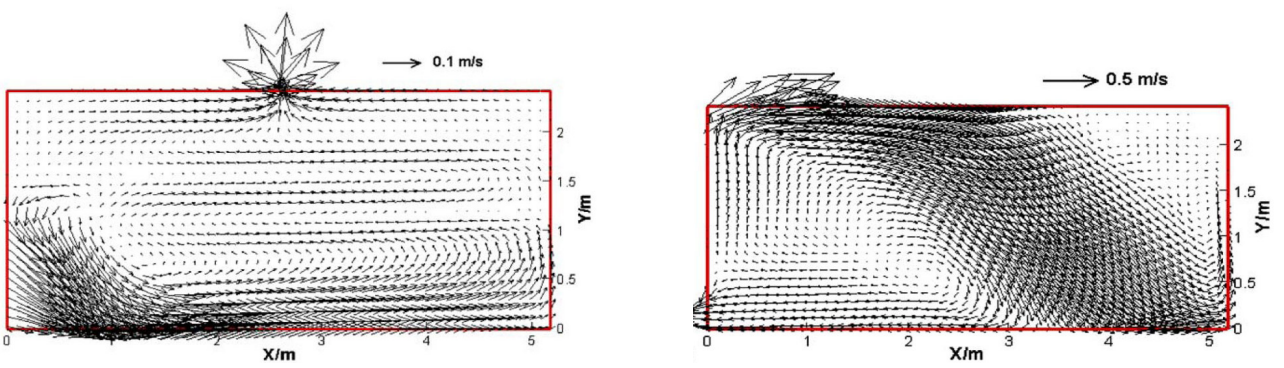

Figura 41 - Diagramas da velocidade do ar em um ambiente com ventilação cruzada, à esquerda, e com ventilação não cruzada, à direita. Fonte: Zhao et al. (2004).

Observa-se, na Figura 41, que a ventilação cruzada tem velocidade do ar de $0,1 \mathrm{~m} / \mathrm{s} \mathrm{e}$ a ventilação não cruzada tem velocidade do ar de $0,5 \mathrm{~m} / \mathrm{s}$. Portanto, a ventilação cruzada permite o deslocamento do ar com velocidade menor do que a ventilação não cruzada.

Na Figura 42, apresentam-se os gráficos de deposição, remoção e ressuspensão das partículas para os ambientes internos, com ventilação cruzada e não cruzada, sendo adotado o modelo de trajetória discreta para simular trajetórias das partículas, além de calcular a velocidade do ar pelo método Euleriano, segundo Zhao et al. (2004).
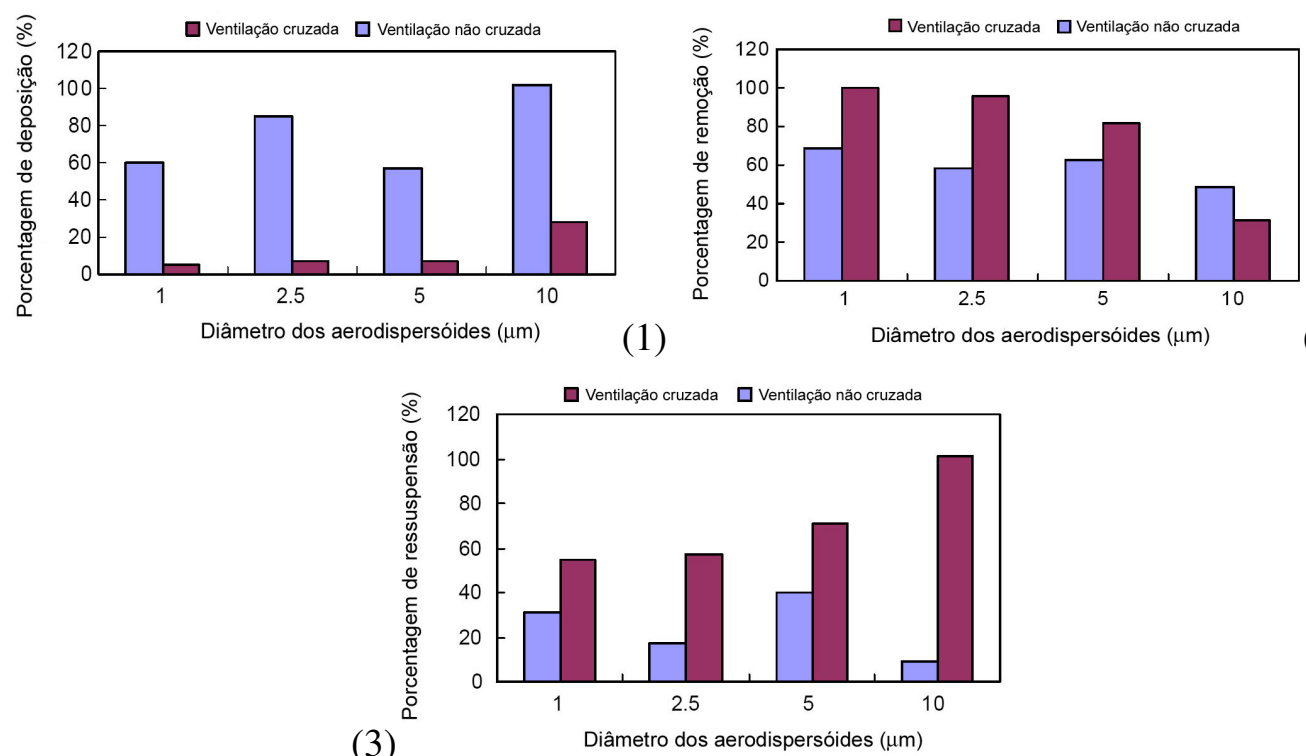

Figura 42 - Deposição de partículas (1), remoção de partículas (2) e ressuspensão de partículas (3), para ventilação cruzada ou não cruzada. Fonte: Zhao et al. (2004). 
No gráfico 1, da Figura 42, observa-se que a porcentagem de deposição para ventilação não cruzada é maior do que para ventilação cruzada. No gráfico 2 , observa-se que a porcentagem de remoção para ventilação cruzada é maior do que para ventilação não cruzada, com exceção das partículas maiores que $10 \mu \mathrm{m}$, tendo comportamento inverso. No gráfico 3, observa-se que a porcentagem de ressuspensão para ventilação cruzada é maior do que para ventilação não cruzada.

Em um ambiente interno, quanto maior a quantidade de portas e janelas abertas e a disposição das mesmas de modo que permita ventilação cruzada, tanto menor será a concentração de aerodispersóides.

A seguir, na Tabela 10, apresentam-se os valores médios das concentrações em massa de aerodispersóides, menores que $2,5 \mu \mathrm{m}$ e $10 \mu \mathrm{m}$, em função das quantidades de pavimento nos edifícios, segundo Chao e Wong (2002).

Tabela 10 - Valores médios das concentrações em massa para alguns pavimentos nos edifícios. Fonte: Chao e Wong (2002).

\begin{tabular}{|c|c|c|c|}
\hline Pavimentos & $\begin{array}{l}\text { Números de } \\
\text { apartamentos }\end{array}$ & $\begin{array}{l}\text { Concentração em } \\
\text { massa de } \mathbf{M P}_{2,5} \\
\left(\mu \mathrm{g} / \mathrm{m}^{3}\right)\end{array}$ & $\begin{array}{l}\text { Concentração em } \\
\text { massa de } \mathbf{M P}_{10} \\
\left(\mu \mathrm{g} / \mathbf{m}^{3}\right)\end{array}$ \\
\hline$G-4$ & 4 & 50,4 & 65,9 \\
\hline $5-9$ & 10 & 40,7 & 57,6 \\
\hline $10-14$ & 5 & 47,4 & 66,1 \\
\hline $15-19$ & 6 & 43,8 & 64,4 \\
\hline $20-24$ & 4 & 52,8 & 73,7 \\
\hline $25-29$ & 2 & 43,6 & 58,1 \\
\hline $30-34$ & 2 & 41,6 & 62,9 \\
\hline $35-40$ & 1 & 57,5 & 83,3 \\
\hline
\end{tabular}

A Tabela 10 indica que a concentração em massa de aerodispersóides está relacionada com a quantidade de pavimentos em um edifício. Nos edifícios, os 
apartamentos localizados entre os pavimentos 35 e 40, apresentaram concentrações médias em massa de aerodispersóides de $57,5 \mu \mathrm{g} / \mathrm{m}^{3}$ e $83,3 \mu \mathrm{g} / \mathrm{m}^{3}$, respectivamente, para partículas menores que $2,5 \mu \mathrm{m}$ e $10 \mu \mathrm{m}$, atribuindo esse fato ao provável fechamento das janelas nestes pavimentos. Portanto, as concentrações de aerodispersóides em massa são maiores nos últimos pavimentos dos edifícios.

$\mathrm{Na}$ Figura 43 apresenta-se a correlação entre a concentração em massa de aerodispersóides, menores que 2,5 e $10 \mu \mathrm{m}$, e as condições de tráfego distante, próximo às vias secundárias e próximo às vias principais, de acordo com Chao e Wong (2002).

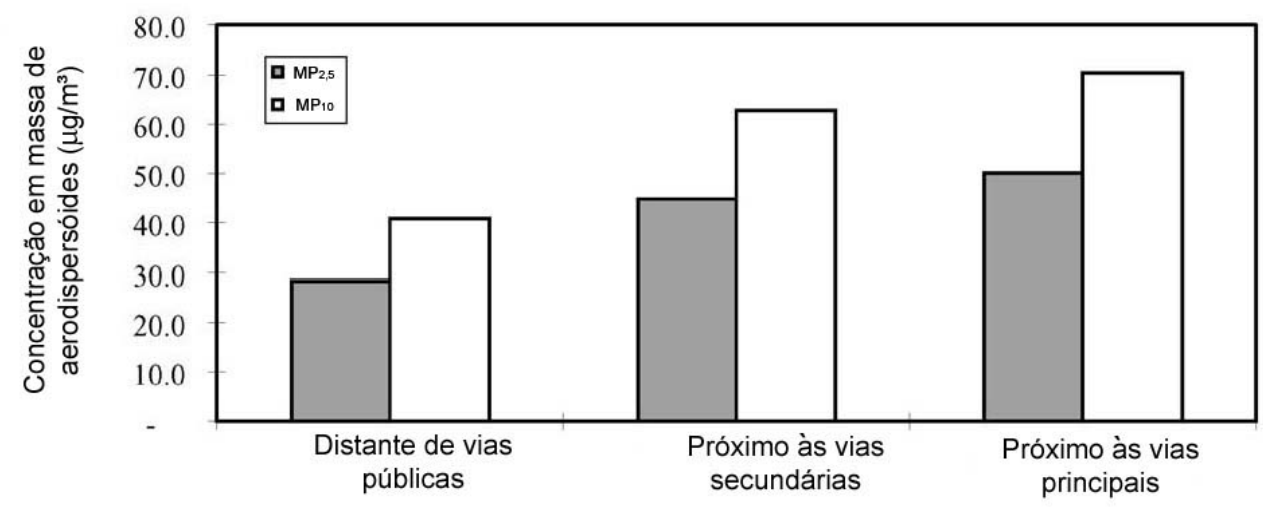

Figura 43 - Correlação entre a concentração em massa e as condições do tráfego. Fonte: Chao e Wong. (2002).

Na Figura 43 a concentração em massa de aerodispersóides, menores que 2,5 e 10 $\mu \mathrm{m}$, é maior à medida que os ambientes internos localizam-se próximos das vias principais. Para $\mathrm{MP}_{2,5}$, a concentração em massa de aerodispersóides foi em torno de $29 \mu \mathrm{g} / \mathrm{m}^{3}, 45 \mu \mathrm{g} / \mathrm{m}^{3}$ e $50 \mu \mathrm{g} / \mathrm{m}^{3}$, respectivamente, para distante das vias públicas, próximo às vias secundárias e próximo às vias principais. Para $\mathrm{MP}_{10}$, a concentração em massa de aerodispersóides foi em torno de $41 \mu \mathrm{g} / \mathrm{m}^{3}, 65 \mu \mathrm{g} / \mathrm{m}^{3}$ e $70 \mu \mathrm{g} / \mathrm{m}^{3}$, respectivamente, para distante das vias públicas, próximo às vias secundárias e próximo às vias principais. 
A seguir, na Figura 44, apresenta-se a correlação entre a concentração em massa e a presença de fumantes em residências com relação aos elementos químicos, conforme Na et al. (2004).

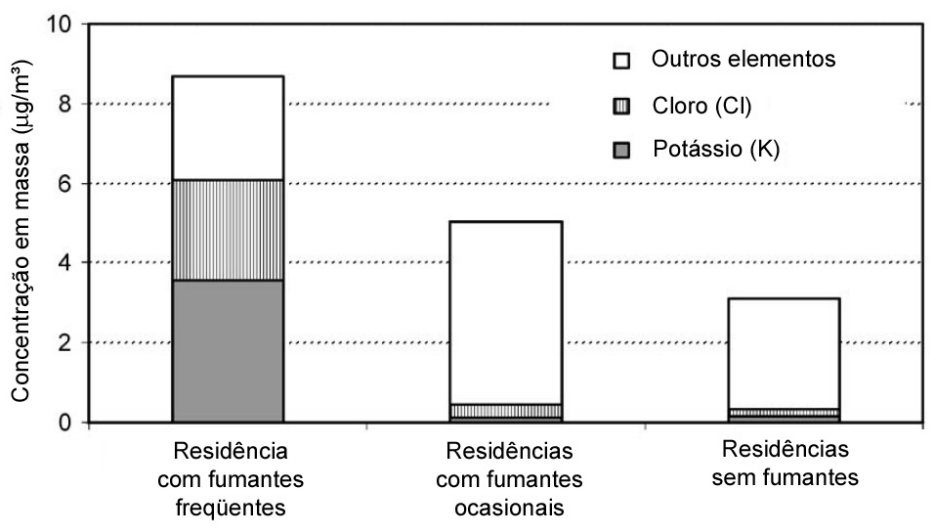

Figura 44 - Correlação entre a concentração em massa e a presença de fumaça de cigarro com relação aos elementos químicos em residências. Fonte: Na el at. (2004).

Segundo os autores, os principais elementos químicos presentes na fumaça de cigarro são o cloro $(\mathrm{Cl})$ e o potássio $(\mathrm{K})$. A concentração em massa foi maior na residência com fumantes freqüentes, sendo a principal diferença, entre esta residência e as residências sem fumantes, o elevado nível de cloro e potássio. 


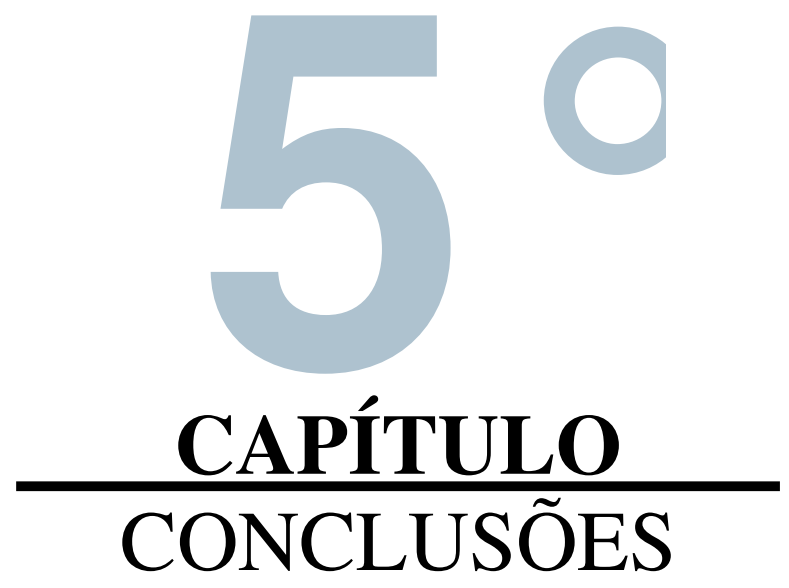




\section{CONCLUSÕES}

Com o trabalho desenvolvido foi possível avaliar a qualidade do ar interno com ênfase na concentração de aerodispersóides nos edifícios localizados na RMSP, concluindo-se que:

- Nos ambientes com sistema de ventilação natural, a concentração média de aerodispersóides foi em geral maior do que nos ambientes com sistema de condicionamento de ar, além da influência da localização.

- As atividades humanas domésticas foram responsáveis pela maior emissão e ressuspensão dos aerodispersóides do que a degradação dos materiais, as reações fotoquímicas, a umidade, os produtos químicos e a interação entre eles.

- As concentrações médias em massa e em número de aerodispersóides, durante as atividades humanas domésticas (cozimento, reforma, limpeza, entre outras), foram aproximadamente oito vezes maior do que as concentrações com atividades humanas profissionais ou em ambientes com menor ocupação durante o dia.

As informações também indicaram que quanto menor for a umidade relativa e maior for a temperatura interna, maior será a concentração de aerodispersóides. Igualmente atribuído esse aumento ao fato de haver ou não atividades ocupacionais nos ambientes internos.

Neste sentido existe a necessidade de monitoramento dos aerodispersóides para evitar ou amenizar os sintomas relacionados com a Síndrome dos Edifícios Doentes (SED) e as Doenças Relacionadas aos Edifícios (DRE), pois como se verificou na literatura internacional e em capítulos anteriores, existem problemas causados à saúde dos usuários que podem ter correlação com várias substâncias encontradas no ar de interiores, as quais estão acima dos valores referenciados. 
Se no início muitas dificuldades residiram na falta de informações quantitativas e na avaliação dos sistemas, hoje os dados disponibilizados indicam necessidades de intervenção, com relação aos projetos de arquitetura, aos sistemas de ventilação e/ou condicionamento de ar, às fontes de poluição que dispõem. Assim, para prover uma boa qualidade do ar interno, deve-se atentar para esta questão.

Espera-se que este trabalho seja um ponto de partida e motivação para novas pesquisas de prazo mais longo em ambientes mais específicos. Pensa-se também que as novas pesquisas possam qualificar os aerodispersóides nas atividades que mostraram maiores concentrações, além de correlacionar com as incidências de doenças ocupacionais, tanto da indústria da construção civil, quanto daquelas decorrentes das atividades exercidas nos edifícios já ocupados. 


\section{REFERÊNCIAS BIBLIOGRÁFICAS}

ABADIE, M.; LIMAM, K.; ALLARD, F. Indoor particle pollution: effect of wall textures on particle deposition. Building and Environment, France, v. 36, f. 7, ago. 2001, p. 821-827.

ADGATE, J. L., RAMACHANDRAN, G., PRATT, G. C., WALLER, L. A., SEXTON, K. Spatial and temporal variability in outdoor, indoor, and personal PM2.5 exposure. Atmospheric Environment, USA, v. 36, f. 20, Jul. 2002, p. 3255-3265.

ALlARD, P. F. Project and Problem Definition in Building Air Quality Investigations. Design Protocol for Monitoring Enduro Air Quality, ASTM STP 1002, N. L. Nagda and J. P. Harper, Eds., American Society for Testing and Material, Philadelphia, 1989, p. 73-79.

ALMEIDA, I. T. Comparação de técnicas de análise de tamanho de partículas coletadas em ambiente de mineração. Tese de Doutorado, Escola Politécnica da Universidade de São Paulo, São Paulo, 2005, p. 12.

ASSIMAKOPOULOS, V. D.; HELMIS, C. G. On the study of a sick building: the case of Athens Air Traffic Control Tower. Energy and Buildings, Greece, v. 36 , f. 1 , jan. 2004, p. 15-22.

ASSOCIAÇÃO BRASILEIRA DE NORMAS TÉCNICAS - ABNT. Áreas limpas Classificação e controle de contaminação. Rio de Janeiro, 1996.

Material particulado em suspensão na atmosfera - Determinação da concentração de partículas inaláveis pelo método do amostrador de grande volume acoplado a um separador inercial de partículas. Rio de Janeiro, 1995. 
ASSUNÇÃO, J. V. Poluição atmosférica. In: CASTELlANO, E. G., ed. Desenvolvimento sustentado: problemas e estratégias. São Paulo, Academia de Ciências do Estado de São Paulo, 1998, p. 271-308.

Importância da ventilação no controle da Síndrome dos Edifícios Doentes. Encontro Brasileiro de Higienistas Ocupacionais, 04, São Paulo, 19-22 de agosto de 1997, p. 08.

ASSUNÇÃO, J. V.; ANDRADE, A.; MONOSOWSKI, E. O planejamento territorial aplicado no controle da poluição ambiental no Estado de São Paulo. $10^{\circ}$ (décimo) Congresso Brasileiro de Engenharia Sanitária e Ambiental, Manaus, 21-26 de janeiro de 1979.

AYlesworth, T. G. Poluição do Ar e da Água. Rio de Janeiro, Ed. "O Cruzeiro" S. A., f. 133, 1971, p. 25-32.

BEHNE, M. Indoor air quality in rooms with cooled ceiling. Mixing ventilation or rather displacement ventilation? Energy and Buildings, USA, v. 30, f. 2, jun. 1999, p. 155-166.

BARTZ, C. Autodesk. Acesso em: 23 de julho de 2005. Disponível em: http://usa.autodesk.com.

BRAGA, B.; HESPANHOL, I.; CONEJO, J. G. L.; MIERZWA, J. C.; BARROS, M. T. L.; SPENCER, M.; PORTO, M.; NUCCI, N.; JULIANO, N.; EIGER, S. Introdução à Engenharia Ambiental - $O$ desafio do desenvolvimento sustentável. Escola Politécnica da Universidade de São Paulo, Departamento de Engenharia Hidráulica e Sanitária, 2ª edição, São Paulo, 2005.

BRASIL. Portaria $n^{0}$ 3.523/GM de 28 de agosto de 1998. Dispõe sobre como minimizar o risco potencial à saúde dos usuários, em face da permanência prolongada em ambientes dotados de sistemas de ar condicionado, e dá outras 
providências. Ministério da Saúde - MS. Acesso em 26 de julho de 2005. Disponível em: http://www.techcleaner.com.br.

. Resolução - no 9 de 16 de janeiro de 2003. Dispõe sobre os Padrões Referenciais de Qualidade do Ar Interior em Ambientes Climatizados Artificialmente de Uso Público e Coletivo, e dá outras providências. Agência Nacional de Vigilância Sanitária - ANVISA. Acesso em 26 de julho de2005. Disponível em: http://www.techcleaner.com.br.

. Resolução - no 3 de 28 de junho de 1990. Dispõe sobre os Padrões Primários e Secundários de Qualidade do Ar e ainda os Critérios para Episódio Agudos de Poluição do Ar. Conselho Nacional do Meio Ambiente - CONAMA.

CHAO, C. Y. H.; WAN, M. P.; CHENG, E. C. K. Penetration coefficient and deposition rate as a function of particle size in non-smoking naturally ventilated residences. Atmospheric Environment, China, v. 37, f. 30, set. 2003, p. $4233-4241$.

CHAO, C. Y.; WONG, K. K. Residential indoor PM10 and PM2.5 in Hong Kong and the elemental composition. Atmospheric Environment, China, v. 36, f. 2, Jan. 2002, p. 265-277.

COHN, P. E. Medição contínua de emissão de poluentes gasosos, particulados e líquidos. The Instrumentation, Systems, and Automation Society, São Paulo, Set. 2003, p. 31-37.

COMPANHIA DE TECNOLOGIA DE SANEAMENTO AMBIENTAL. Relatório de qualidade do ar no Estado de São Paulo 2004. São Paulo, CETESB, 2004. (Série Relatórios) 
EPA (Environmental Protection Agency). Indoor Air Quality Education and Assessment Guidance (I-BEAM). Acesso em: 14 de maio de 2003. Disponível em: http://www.epa.gov/iaq/largebldgs/i-beam_html/ibeami.htm.

GELlER, M. D.; CHANG, M.; SIOUTAS, C.; OSTRO, B. D.; LIPSETT, M. J. Indoor/outdoor relationship and chemical composition of fine and coarse particles in the southern California deserts. Atmospheric Environment, USA, v. 36, f. 6, fev. 2002, p. 1099-1110.

GUO, H., LEE, S. C., CHAN, L. Y. Indoor air quality investigation at airconditioned and non-air-conditioned markets in Hong Kong. Science of the Total Environment, China, v. 323, f. 1-3, Mai. 2004, p. 87-98.

HANSEN, S. J. Managing Indoor Air Quality. Lilburn, GA: The Fairmont Press, Inc. 1991, p. 317.

HE, C.; MORAWSKA, L.; HITCHINS, J.; GILBERT, D. Contribution from indoor sources to particle number and mass concentrations in residential houses. Atmospheric Environment, Australia, v. 38, f. 21, jul. 2004, p. 34053415.

HOWARD-REED, C.; WALLACE, L. A.; EMMERICH, S. J. Effect of ventilation systems and air filters on decay rates of particles by indoor sources in an occupied townhouse. Atmospheric Environment, USA, v. 37, f. 38, dez. 2003, p. $5295-5306$.

ISAIQ-CIB (International Society of Indoor Air Quality and Climate and International Council for Research and Innovation in Building and Construction). Performance Criteria of Buildings for Health and Comfort. International Council for Research and Innovation in Building and Construction. International Society of Indoor Air Quality and Climate, TG 42, Helsinki, Finland, 2003. 
JONES, A. P. Asthma and domestic air quality. Social Science \& Medicine, China, v. 47 , f. 6 , Set. 1998 , p. $755-764$.

Indoor air quality and health. Atmospheric Environment, England, v. 33, f. 28, dez. 1999, p. 4535-4564.

JONES, N. C.; THORNTON, C. A.; MARK, D.; HARRISON, R. M. Indoor/outdoor relationships of particulate matter in domestic homes with roadside, urban and rural locations. Atmospheric Environment, England, v. 34, f. 16, 2000, p. 2603-2612.

JOSÉ-ALONSO, J. F. S.; VELASCO-GOMEZ, E.; REY-MARTÍNEZ, F. J.; ALVAREZ-GUERRA, M.; PELÀEZ, C. G. Study on environmental quality of a surgical block. Energy and Buildings, Spain, v. 29, f. 2, 1999, p. 179-187.

JUNKER, M.; KOLLER, T.; MONN, C. An assessment of indoor air contaminants in buildings with recreational activity. The Science of the Total Environment, Switzerland, v. 246, f. 2-3, fev. 2000, p. 139-152.

KOSONEN, R.; TAN, F. The effect of perceived indoor air quality on productivity loss. Energy and Buildings, Finland, v. 36, f. 10, out. 2004, p. 981986.

LEE, S. C., GUO, H., LI, W. M., CHAN, L. Y. Inter-comparison of air pollutant concentrations in different indoor environments in Hong Kong. Atmospheric Environment, China, v. 36, f. 12, Abr. 2002, p. 1929-1940.

LOMBORG, B. O ambientalista cético: medindo o verdadeiro estado do mundo. Rio de Janeiro, ed. Campus, 2002, p. 532.

MATSON, U. Comparison of the modelling and the experimental results on concentrations of ultra-fine particles indoors. Building and Environment, Sweden, v. 40, f. 7, jul. 2005, p. 996-1002. 
MESQUITA, A. L. S.; GUIMARÃES, F. A.; NEFUSSI, N. Engenharia de ventilação natural. CETESB, São Paulo, 1988, p. 442.

MORAWSKA, L.; THOMAS, S.; GILBERT, D.; GREENAWAY, C.; RIJNDERS, E. A study of the horizontal and vertical profile of submicrometer particles in relation to a busy road. Atmospheric Environment, Australia, v. 33, f. 8, abr. 1999, p. 1261-1274.

NA, K.; SAWANT, A. A.; COCKER III, D. R. Trace elements in fine particulate matter within a community in western Riverside County, CA: focus on residential sites and a local high school. Atmospheric Environment, USA, v. 38, f. 18, jun. 2004, p. 2867-2877.

NIU, J. L.; BURNETT, J. Setting up the criteria and credit-awarding scheme for building interior material selection to achieve better indoor air quality. Environment International, China, v. 26, f. 7-8, jun. 2001, p. 573-580.

OMS (ORGANIZAÇÃO MUNDIAL DA SAÚDE). Critérios de Qualidade do Ar. Genebra, Suíça, 1999.

PAIVA, C. Cilindro de vidro, alumínio e transparência. Finestra, São Paulo, v. 40, mar. 2004. Acesso em: 14 de junho de 2005. Disponível e m: http://www.arcoweb.com.br/arquitetura/arquitetura574.asp.

PRADO, R. T. A. Contribuição ao estudo do papel da engenharia nas interações entre o homem, o edifício e o ambiente. Tese de Livre Docência, Escola Politécnica da Universidade de São Paulo, São Paulo, 2003, p. 197.

PRADO, R. T. A.; CARMO, A. T. Qualidade do Ar Interno. Texto Técnico, Escola Politécnica da Universidade de São Paulo, São Paulo, 1999, p. 35. 
PRORAD. Diretrizes para limitação da exposição a campos elétricos, magnéticos e eletromagnéticos variáveis no tempo (até $300 \mathbf{G z}$ ). Acesso em: 04 de janeiro de 2006 Disponível e m: http://www.prorad.com.br

ROULET, C. A. Indoor environment quality in buildings and its impact on outdoor environment. Energy and Buildings, Switzerland, v. 33, f. 3, feb. 2001, p. 183-191.

SANTOS, A. M. A. Exposição Ocupacional a Poeiras em Marmorarias: Tamanhos de Partículas Característicos. Universidade Federal de Minas Gerais, Belo Horizonte, Minas Gerais, março de 2005.

TONG, S. T. Y.; LAM, K. C. Home sweet home? A case study of household dust contamination in Hong Kong. The Science of the Total Environment, China, v. 256, 2000, p. 115-123.

TSE, M. S.; CHAU, C. K.; LEE W. L. Assessing the benefit and cost for a voluntary indoor air quality certification scheme in Hong Kong. The Science of the Total Environment, China, v. 320, f. 2-3, mar. 2004, p. 89-107.

TSI Inc. Ptrak and Dust Trak. Acesso em: 12 de julho de 2003. Disponível em: http://www.tsi.com.

VIRTA, J.; KOIVULA, M.; HUSSEIN, T.; KOPONEN, S.; HAKKARAINEN, H.; KYMÄLÄINEN, H. R.; HÄMERI, K.; KULMALA, M.; HAUTALA, M. Emissions from thermal insulations - part 1: development and characteristics of the test apparatus. Building and Environment, Finland, v. 40, f. 6 , jun. 2005 , p. $797-802$.

WALLACE, L. A.; EMMERICH, S. J.; HOWARD-REED, C. Effect of central fans and in-duct filters on deposition rates of ultrafine and fine particles in an 
occupied townhouse. Atmospheric Environment, USA, v. 38, f. 3, jan. 2004, p. 405-413.

WARGOCKI, P.; BAKÓ-BIRÓ, Z.; CLAUSEN, G.; FANGER, P. O. Air quality in a simulated office environment as a result of reducing pollution sources and increasing ventilation. Energy and Buildings, Denmark, v. 34, f. 8, set. 2002, p. 775-783.

WOLKOFF, P.; SCHNEIDER, T.; KILDES $\emptyset$, J.; DEGERTH, R.; JAROSZEWSKI, M.; SCHUNK, H. Risk in cleaning: chemical and physical exposure. The Science of the Total Environment, v. 215, f. 1-2, abr. 1998, p. 135-156.

WOLKOFF, P.; NIELSEN, P. A. A new approach for indoor climate labeling of building materials - emission testing modeling, and comfort evaluation. Atmospheric Environment, v. 30, 1995, p. 2679-2689.

WOLKOFF, P.; NIELSEN, G. D. Organic compounds in indoor air their relevance for perceived enduro air quality? Atmospheric Environment, v. 35, 2001, p. 4407-4417.

WONG, N. H.; HUANG, B. Comparative study of the indoor air quality of naturally ventilation and air-conditioned bedrooms of residential buildings in Singapore. Building and Environment, Singapore, v. 39, f. 9, set. 2004, p. 1115-1123.

YANG, L.; ZHANG, G.; LI, Y.; CHEN, Y. Investigating potential of natural driving forces for ventilation in four major cities in China. Building and Environment, China, v. 40, f. 6, jun. 2005, p. 738-746.

ZHAO, B., ZHANG, Y., LI, X., YANG, X., HUANG, D. Comparison of indoor aerosol particle concentration and deposition in different ventilated rooms 
by numerical method. Building and Environment, China, v. 39, f. 1, Jan. 2004, p. $1-8$.

ZHENG, M., FANG, M., WANG, F., TO, K. L. Characterization of the solvent extractable organic compounds in PM2.5 aerosols in Hong Kong. Atmospheric Environment, China, v. 34, f. 17, 2000, p. 2691-2702. 


\title{
ANEXO A - Resolução n ${ }^{\circ} 9$
}

\author{
16 de janeiro de 2003
}

O Diretor da Diretoria Colegiada da Agência Nacional de Vigilância Sanitária , no uso da atribuição que Ihe confere a Portaria n 570, do Diretor Presidente, de 3 de outubro de 2002;

Considerando o $\S 3^{\circ}$, do art. 111 do Regimento Interno aprovado pela Portaria n. ${ }^{\circ} 593$, de 25 de agosto de 2000 , republicada no DOU de 22 de dezembro de 2000 ,

Considerando a necessidade de revisar e atualizar a RE/ANVISA no 176, de 24 de outubro de 2000, sobre Padrões Referenciais de Qualidade do Ar Interior em Ambientes Climatizados Artificialmente de Uso Público e Coletivo, frente ao conhecimento e a experiência adquirida no país nos dois primeiros anos de sua vigência; considerando o interesse sanitário na divulgação do assunto;

Considerando a preocupação com a saúde, a segurança, o bem-estar e o conforto dos ocupantes dos ambientes climatizados;

Considerando o atual estágio de conhecimento da comunidade científica internacional, na área de qualidade do ar ambiental interior, que estabelece padrões referenciais e/ou orientações para esse controle;

Considerando o disposto no art. $2^{\circ}$ da Portaria GM/MS n. 03.523 , de 28 de agosto de 1998;

Considerando que a matéria foi submetida à apreciação da Diretoria Colegiada que a aprovou em reunião realizada em 15 de janeiro de 2003, resolve:

Art. 10 Determinar a publicação de Orientação Técnica elaborada por Grupo Técnico Assessor, sobre Padrões Referenciais de Qualidade do Ar Interior, em ambientes climatizados artificialmente de uso público e coletivo, em anexo.

Art. $2^{\circ}$ Esta Resolução entra em vigor na data de sua publicação.

\section{CLÁUDIO MAIEROVITCH PESSANHA HENRIQUES}

\section{ANEXO}

ORIENTAÇÃO TÉCNICA ELABORADA POR GRUPO TÉCNICA ASSESSOR SOBRE PADRÕES REFERENCIAIS DE QUALIDADE DO AR INTERIO R EM AMBIENTES CLIMATIZADOS ARTIFICIALMENTE DE USO PÚBLICO E COLETIVO

$$
\text { I - HISTÓRICO }
$$

O Grupo Técnico Assessor de estudos sobre Padrões Referenciais de Qualidade do Ar Interior em ambientes climatizados artificialmente de uso público e coletivo, foi constituído pela Agência Nacional de Vigilância Sanitária - ANVISA, no âmbito da Gerência Geral de Serviços da Diretoria de Serviços e Correlatos e instituído por membros das seguintes instituições:

Sociedade Brasileira de Meio Ambiente e de Qualidade do Ar de Interiores/BRASINDOOR, Laboratório Noel Nutels Instituto de Química da UFRJ, Ministério do Meio Ambiente, Faculdade de Medicina da USP, Organização Panamericana de Saúde/OPAS, Fundação Oswaldo Cruz/FIOCRUZ, Fundação Jorge Duprat Figueiredo de Segurança e Medicina do Trabalho - FUNDACENTRO/MTb, Instituto Nacional de Metrologia Normalização e Qualidade Industrial/INMETRO, Associação Paulista de Estudos e Controle de Infecção Hospitalar/APECIH e, Serviço de Vigilância Sanitária do Ministério da Saúde/RJ, Instituto de Ciências Biomédicas - ICB/USP e Agência Nacional de Vigilância Sanitária.

Reuniu-se na cidade de Brasília/DF, durante o ano de 1999 e primeiro semestre de 2000, tendo como metas:

1. estabelecer critérios que informem a população sobre a qualidade do ar interior em ambientes climatizados artificialmente de uso público e coletivo, cujo desequilíbrio poderá causar agravos a saúde dos seus ocupantes;

2. instrumentalizar as equipes profissionais envolvidas no controle de qualidade do ar interior, no planejamento, elaboração, análise e execução de projetos físicos e nas ações de inspeção de ambientes climatizados artificialmente de uso público e coletivo.

Reuniu-se na cidade de Brasília/DF, durante o ano de 2002, tendo como metas: 
1. Promover processo de revisão na Resolução ANVISA -RE 176/00

2. Atualiza-la frente a realidade do conhecimento no país.

3. Disponibilizar informações sobre o conhecimento e a experiência adquirida nos dois primeiros anos de vigência da RE 176.

\section{II - ABRANGÊNCIA}

O Grupo Técnico Assessor elaborou a seguinte Orientação Técnica sobre Padrões Referenciais de Qualidade do $\mathrm{Ar}$ Interior em ambientes climatizados artificialmente de uso público e coletivo, no que diz respeito a definição de valores máximos recomendáveis para contaminação biológica, química e parâmetros físicos do ar interior, a identificação das fontes poluentes de natureza biológica, química e física, métodos analíticos (Normas Técnicas 001, 002, 003 e 004 ) e as recomendações para controle ( Quadros I e II ).

Recomendou que os padrões referenciais adotadas por esta Orientação Técnica sejam aplicados aos ambientes climatizados de uso público e coletivo já existentes e aqueles a serem instalados. Para os ambientes climatizados de uso restrito, com exigências de filtros absolutos ou instalações especiais, tais como os que atendem a processos produtivos, instalações hospitalares e outros, sejam aplicados as normas e regulamentos específicos.

\section{III - DEFINIÇÕES}

Para fins desta Orientação Técnica são adotadas as seguintes definições, complementares às adotadas na Portaria GM/MS n. $3.523 / 98$ :

a) Aerodispersóides : sistema dispersa, em um meio gasoso, composto de partículas sólidas e/ou líquidas. O mesmo que aerosol ou aerossol.

b) ambiente aceitável : ambientes livres de contaminantes em concentrações potencialmente perigosas à saúde dos ocupantes ou que apresentem um mínimo de $80 \%$ dos ocupantes destes ambientes sem queixas ou sintomatologia de desconforto, 2

c) ambientes climatizados: são os espaços fisicamente determinados e caracterizados por dimensões e instalações próprias, submetidos ao processo de climatização, através de equipamentos.

d) ambiente de uso público e coletivo : espaço fisicamente determinado e aberto a utilização de muitas pessoas.

e) ar condicionado : é o processo de tratamento do ar, destinado a manter os requerimentos de Qualidade do Ar Interior do espaço condicionado, controlando variáveis como a temperatura, umidade, velocidade, material particulado, partículas biológicas e teor de dióxido de carbono $\left(\mathrm{CO}_{2}\right)$.

f) Padrão Referencial de Qualidade do Ar Interior: marcador qualitativo e quantitativo de qualidade do ar ambiental interior, utilizado como sentinela para determinar a necessidade da busca das fontes poluentes ou das intervenções ambientais.

g) Qualidade do Ar Ambiental Interior : Condição do ar ambiental de interior, resultante do processo de ocupação de um ambiente fechado com ou sem climatização artificial.

h) Valor Máximo Recomendável : Valor limite recomendável que separa as condições de ausência e de presença do risco de agressão à saúde humana.

\section{IV - PADRÕES REFERENCIAIS}

Recomenda os seguintes Padrões Referenciais de Qualidade do Ar Interior em ambientes climatizados de uso público e coletivo.

1 - O Valor Máximo Recomendável - VMR, para contaminação microbiológica deve ser $750 \mathrm{ufc} / \mathrm{m}^{3}$ de fungos, para a relação I/E menor do que 1,5 , onde I é a quantidade de fungos no ambiente interior e $E$ é a quantidade de fungos no ambiente exterior.

NOTA: A relação I/E é exigida como forma de avaliação frente ao conceito de normalidade, representado pelo meio ambiente exterior e a tendência epidemiológica de amplificação dos poluentes nos ambientes fechados.

1.1 - Quando o VMR for ultrapassado ou a relação I/E for maior do que 1,5, é necessário fazer um diagnóstico de fontes poluentes para uma intervenção corretiva.

1.2 - É inaceitável a presença de fungos patogênicos e toxigênicos. 
2 - Os Valores Máximos Recomendáveis para contaminação química são:

2.1 - 1000 ppm de dióxido de carbono - $\left(\mathrm{CO}_{2}\right)$, como indicador de renovação de ar externo, recomendado para conforto e bem-estar.

$2.2-80 \mu \mathrm{g} / \mathrm{m}^{3}$ de aerodispersóides totais no ar, como indicador do grau de pureza do ar e limpeza do ambiente climatizado.

NOTA: Pela falta de dados epidemiológicos brasileiros é mantida a recomendação como indicador de renovação do ar o valor $=1000$ ppm de Dióxido de carbono $-\mathrm{CO}_{2}$

3 - Os valores recomendáveis para os parâmetros físicos de temperatura, umidade, velocidade e taxa de renovação do ar e de grau de pureza do ar, deverão estar de acordo com a NBR 6401 - Instalações Centrais de Ar Condicionado para Conforto - Parâmetros Básicos de Projeto da ABNT - Associação Brasileira de Normas Técnicas.

3.1 - a faixa recomendável de operação das Temperaturas de Bulbo Seco, nas condições internas para verão, deverá variar de $230 \mathrm{C}$ a $260 \mathrm{C}$, com exceção de ambientes de arte que deverão operar entre $210 \mathrm{C}$ e 230C. A faixa máxima de operação deverá variar de $26,50 \mathrm{C}$ a $270 \mathrm{C}$, com exceção das áreas de acesso que poderão operar até $280 \mathrm{C}$. A seleção da faixa depende da finalidade e do local da instalação. Para condições internas para inverno, a faixa recomendável de operação deverá variar de 200C a 220C.

3.2 - a faixa recomendável de operação da Umidade Relativa, nas condições internas para verão, deverá variar de $40 \%$ a $65 \%$, com exceção de ambientes de arte que deverão operar entre $40 \%$ e $55 \%$ durante todo o ano. O valor máximo de operação deverá ser de $65 \%$, com exceção das áreas de acesso que poderão operar até $70 \%$. A seleção da faixa depende da finalidade e do local da instalação. Para condições internas para inverno, a faixa recomendável de operação deverá variar de $35 \%$ a $65 \%$.

3.3 - o Valor Máximo Recomendável - VMR de operação da Velocidade do Ar, no nível de 1,5m do piso, na região de influência da distribuição do ar é de menos $0,25 \mathrm{~m} / \mathrm{s}$.

3.4 - a Taxa de Renovação do Ar adequada de ambientes climatizados será, no mínimo, de 27 $\mathrm{m} 3 /$ hora/pessoa, exceto no caso específico de ambientes com alta rotatividade de pessoas. Nestes casos a Taxa de Renovação do Ar mínima será de $17 \mathrm{~m}^{3} / \mathrm{hora} /$ pessoa, não sendo admitido em qualquer situação que os ambientes possuam uma concentração de $\mathrm{CO}_{2}$, maior ou igual a estabelecida em IV-2.1, desta Orientação Técnica.

3.5 - a utilização de filtros de classe G1 é obrigatória na captação de ar exterior. O Grau de Pureza do Ar nos ambientes climatizados será obtido utilizando-se, no mínimo, filtros de classe G-3 nos condicionadores de sistemas centrais, minimizando o acúmulo de sujidade nos dutos, assim como reduzindo os níveis de material particulado no ar insuflado2.

Os padrões referenciais adotados complementam as medidas básicas definidas na Portaria GM/MS n. 0 3.523/98, de 28 de agosto de 1998, para efeito de reconhecimento, avaliação e controle da Qualidade do $\mathrm{Ar}$ Interior nos ambientes climatizados. Deste modo poderão subsidiar as decisões do responsável técnico pelo gerenciamento do sistema de climatização, quanto a definição de periodicidade dos procedimentos de limpeza e manutenção dos componentes do sistema, desde que asseguradas as freqüências mínimas para os seguintes componentes, considerados como reservatórios, amplificadores e disseminadores de poluentes.

\begin{tabular}{|l|l|}
\hline \multicolumn{1}{|c|}{ Componente } & \multicolumn{1}{|c|}{ Periodicidade } \\
\hline Tomada de ar externo & $\begin{array}{l}\text { Limpeza mensal ou quando descartável até sua } \\
\text { obliteração (máximo 3 meses) }\end{array}$ \\
\hline Unidades filtrantes & $\begin{array}{l}\text { Limpeza mensal ou quando descartável até sua } \\
\text { obliteração (máximo 3 meses) }\end{array}$ \\
\hline Bandeja de condensado & Mensal* \\
\hline Serpentina de aquecimento & Desencrustação semestral e limpeza \\
\hline Serpentina de resfriamento & trimestral \\
\hline Umidificador & Desencrustação semestral e limpeza \\
\hline
\end{tabular}




\begin{tabular}{|l|l|}
\hline & trimestral \\
\hline Ventilador & Semestral \\
\hline Plenum de mistura/casa de & Mensal \\
máquinas & \\
\hline
\end{tabular}

*- Excetuando na vigência de tratamento químico contínuo que passa a respeitar a periodicidade indicada pelo fabricante do produto utilizado.

\section{$\checkmark$ - FONTES POLUENTES}

Recomenda que sejam adotadas para fins de pesquisa e com o propósito de levantar dados sobre a realidade brasileira, assim como para avaliação e correção das situações encontradas, as possíveis fontes de poluentes informadas nos Quadros I e II.

\section{QUADRO I}

Possíveis fontes de poluentes biológicos

\begin{tabular}{|c|c|c|}
\hline Agentes biológicos & $\begin{array}{l}\text { Principais fontes em ambientes } \\
\text { interiores }\end{array}$ & $\begin{array}{c}\text { Principais Medidas de correção em } \\
\text { ambientes interiores }\end{array}$ \\
\hline Bactérias & $\begin{array}{l}\text { Reservatórios com água Estagnada, } \\
\text { torres de resfriamento, bandejas de } \\
\text { condensado, desumificadores, } \\
\text { umidificadores, serpentinas de } \\
\text { condicionadores de ar e superfícies } \\
\text { úmidas e quentes. }\end{array}$ & $\begin{array}{l}\text { Realizar a limpeza e a conservação das } \\
\text { torres de resfriamento; higienizar os } \\
\text { reservatórios e bandejas de Con- } \\
\text { densado ou manter tratamento } \\
\text { contínuo para eliminar as fontes; } \\
\text { eliminar as infiltrações; higienizar as } \\
\text { superfícies. }\end{array}$ \\
\hline Fungos & $\begin{array}{l}\text { Fungos Ambientes úmidos e demais } \\
\text { fontes de multiplicação fúngica, como } \\
\text { materiais porosos orgânicos úmidos, } \\
\text { forros, paredes e isolamentos úmidos; } \\
\text { ar externo, interior de condicionadores } \\
\text { e dutos } \\
\text { sem manutenção, vasos de terra com } \\
\text { plantas. }\end{array}$ & $\begin{array}{l}\text { Corrigir a umidade ambiental; manter } \\
\text { sob controle rígido vazamentos, } \\
\text { infiltrações e condensação de água; } \\
\text { higienizar os ambientes e componentes } \\
\text { do sistema de climatização } \\
\text { ou manter tratamento contínuo para } \\
\text { eliminar as fontes; eliminar materiais } \\
\text { porosos contaminados; eliminar ou } \\
\text { restringir vasos de plantas com cultivo } \\
\text { em terra, ou substituir pelo } \\
\text { cultivo em água (hidroponia); utilizar } \\
\text { filtros G-1 na renovação do ar externo. }\end{array}$ \\
\hline Fungos & $\begin{array}{l}\text { Fungos Ambientes úmidos e demais } \\
\text { fontes de multiplicação fúngica, como } \\
\text { materiais porosos orgânicos úmidos, } \\
\text { forros, paredes e isolamentos úmidos; } \\
\text { ar externo, interior de condicionadores } \\
\text { e dutos } \\
\text { sem manutenção, vasos de terra com } \\
\text { plantas. }\end{array}$ & $\begin{array}{l}\text { Corrigir a umidade ambiental; manter } \\
\text { sob controle rígido vazamentos, } \\
\text { infiltrações e condensação de água; } \\
\text { higienizar os ambientes e componentes } \\
\text { do sistema de climatização } \\
\text { ou manter tratamento contínuo para } \\
\text { eliminar as fontes; eliminar materiais } \\
\text { porosos contaminados; eliminar ou } \\
\text { restringir vasos de plantas com cultivo } \\
\text { em terra, ou substituir pelo } \\
\text { cultivo em água (hidroponia); utilizar } \\
\text { filtros G-1 na renovação do ar externo. }\end{array}$ \\
\hline
\end{tabular}




\begin{tabular}{|l|l|l|}
\hline Protozoários & $\begin{array}{l}\text { Reservatórios de água contaminada, } \\
\text { bandejas e umidificadores de } \\
\text { condicionadores sem manutenção. }\end{array}$ & $\begin{array}{l}\text { Higienizar o reservatório ou manter } \\
\text { tratamento contínuo para eliminar as } \\
\text { fontes. }\end{array}$ \\
\hline Vírus & Hospedeiro humano. & $\begin{array}{l}\text { Adequar o número de ocupantes por } \\
\text { m2 de área com aumento da } \\
\text { renovação de ar; evitar a presença de } \\
\text { pessoas infectadas nos ambientes } \\
\text { climatizados. }\end{array}$ \\
\hline Algas & $\begin{array}{l}\text { Torres de resfriamento e bandejas de } \\
\text { condensado. }\end{array}$ & $\begin{array}{l}\text { Higienizar os reservatórios e bandejas } \\
\text { de condensado ou manter tratamento } \\
\text { contínuo para eliminar as }\end{array}$ \\
\hline Pólen & fontes. \\
\hline Artrópodes & Poeira caseira. & $\begin{array}{l}\text { Manter filtragem de acordo com NBR- } \\
\text { 6401 da ABNT. }\end{array}$ \\
\hline Animais & $\begin{array}{l}\text { Higienizar as superfícies fixas e } \\
\text { mobiliário, especialmente os revestidos } \\
\text { com tecidos e tapetes; restringir ou } \\
\text { eliminar o uso desses }\end{array}$ \\
\hline Roedores, morcegos e aves. & $\begin{array}{l}\text { Restringir o acesso, controlar os } \\
\text { roedores, os morcegos, ninhos de aves } \\
\text { revestimentos. }\end{array}$ \\
\hline & & respectivos excrementos. \\
\hline
\end{tabular}

QUADRO II

Possíveis fontes de poluentes químicos

\begin{tabular}{|l|l|l|}
\hline Agentes & $\begin{array}{c}\text { Principais fontes em ambientes } \\
\text { interiores }\end{array}$ & $\begin{array}{l}\text { Principais medidas de correção em } \\
\text { ambientes interiores }\end{array}$ \\
\hline CO & $\begin{array}{l}\text { Combustão (cigarros, queimadores de } \\
\text { fogões e veículos automotores). }\end{array}$ & $\begin{array}{l}\text { Manter a captação de ar exterior com } \\
\text { baixa concentração de poluentes; } \\
\text { restringir as fontes de combustão; } \\
\text { manter a exaustão em áreas em que } \\
\text { ocorre combustão; eliminar a infiltração } \\
\text { de CO prove-niente de fontes externas; } \\
\text { restringir o tabagismo em áreas } \\
\text { fechadas. }\end{array}$ \\
\hline CO2 & $\begin{array}{l}\text { Produtos de metabolismo humano e } \\
\text { combustão. }\end{array}$ & $\begin{array}{l}\text { Aumentar a renovação de ar exter-no; } \\
\text { restringir as fontes de combusta o } \\
\text { tabagismo em áreas fechadas; eliminar } \\
\text { infiltração de fontes externas. }\end{array}$ \\
\hline NO2 & Combustão & $\begin{array}{l}\text { Restringir as fontes de combustão; } \\
\text { manter a exaustão em áreas em que }\end{array}$ \\
& $\begin{array}{l}\text { ocorre combustão; impedir a infiltra-ção } \\
\text { de NO2 proveniente de fontes externas; } \\
\text { restringir o tabagismo em áreas } \\
\text { fechadas. }\end{array}$ \\
\hline O3 & Máquinas copiadoras e impressoras a \\
\hline laser. & $\begin{array}{l}\text { Adotar medidas específicas para reduzir } \\
\text { a contaminação dos ambien-tes } \\
\text { interiores, com exaustão do ambiente }\end{array}$ \\
\hline
\end{tabular}




\begin{tabular}{|c|c|c|}
\hline & & $\begin{array}{l}\text { ou enclausuramento em locais } \\
\text { exclusivos para os equipa-mentos que } \\
\text { apresentem grande capacidade de } \\
\text { produção de O3. }\end{array}$ \\
\hline Formaldeído & $\begin{array}{l}\text { Materiais de acabamento, mobiliário, } \\
\text { cola, produtos de limpeza } \\
\text { domissanitários }\end{array}$ & $\begin{array}{l}\text { Selecionar os materiais de construção, } \\
\text { acabamento e mobiliário que possuam } \\
\text { ou emitam menos formaldeído; usar } \\
\text { produtos domissanitários que não } \\
\text { contenham formaldeído. }\end{array}$ \\
\hline Material particulado & Poeira e fibras. & $\begin{array}{l}\text { Manter filtragem de acordo com NBR- } \\
6402 \text { da ABNT; evitar isola-mento } \\
\text { termoacústico que possa emitir fibras } \\
\text { minerais, orgânicas e sintéticas para o } \\
\text { ambiente climatizado; reduzir fontes } \\
\text { internas e Ex-ternas; higienizar as } \\
\text { superfícies fixas e mobiliários sem uso } \\
\text { de vassouras, escovas ou espanadores; } \\
\text { selecionar os materiais de construção e } \\
\text { acaba-mento com menor porosidade; } \\
\text { adotar medidas específicas para reduzir } \\
\text { a contaminação dos ambientes } \\
\text { interiores (vide biológicos); restringir o } \\
\text { tabagismo em áreas fechadas. }\end{array}$ \\
\hline Fumo de tabaco & $\begin{array}{l}\text { Queima de cigarro, charuto, cachimbo, } \\
\text { etc. }\end{array}$ & $\begin{array}{l}\text { Aumentar a quantidade de ar externo } \\
\text { admitido para renovação e/ou exaustão } \\
\text { dos poluentes; restringir o tabagismo } \\
\text { em áreas fechadas. }\end{array}$ \\
\hline cov & $\begin{array}{l}\text { Cera, mobiliário, produtos usados em } \\
\text { limpeza e domissanitários, solventes, } \\
\text { materiais de revestimento, } \\
\text { tintas, colas, etc. }\end{array}$ & $\begin{array}{l}\text { Selecionar os materiais de construção, } \\
\text { acabamento, mobiliário; usar produtos } \\
\text { de limpeza e domissanitários que não } \\
\text { contenham COV ou que não apresentem } \\
\text { alta taxa de volatilização e toxicidade. }\end{array}$ \\
\hline COS-V & $\begin{array}{l}\text { Queima de combustíveis e utilização de } \\
\text { pesticidas. }\end{array}$ & $\begin{array}{l}\text { Eliminar a contaminação por fontes } \\
\text { pesticidas, inseticidas e a queima de } \\
\text { combustiveis; manter a captação de ar } \\
\text { exterior afastada de poluentes. }\end{array}$ \\
\hline
\end{tabular}

COV - Compostos Orgânicos Voláteis.

COS-V - Compostos Orgânicos Semi- Voláteis.

Observações - Os poluentes indicados são aqueles de maior ocorrência nos ambientes de interior, de efeitos conhecidos na saúde humana e de mais fácil detecção pela estrutura laboratorial existente no país.

Outros poluentes que venham a ser considerados importantes serão incorporados aos indicados, desde que atendam ao disposto no parágrafo anterior.

\section{VI - AVALIAÇÃO E CONTROLE}

Recomenda que sejam adotadas para fins de avaliação e controle do ar ambiental interior dos ambientes climatizados de uso coletivo, as seguintes Normas Técnicas 001, 002, 003 e 004.

Na elaboração de relatórios técnicos sobre qualidade do ar interior, é recomendada a NBR-10.719 da ABNT - Associação Brasileira de Normas Técnicas.

1 World Health Organization. Indoor air quality: biological contaminants; Copenhagen, Denmark , 1983 ( European Series no 31).

2 American Society of Hearting, Refreigerating and Air Conditioning Engineers, Inc. ASHARAE Standard 62 - Ventilation for Acceptable Indoor Air Quality, 2001

3 Kulcsar Neto, F \& Siqueira, LFG. Padrões Referenciais para Análise de Resultados de Qualidade Microbiológica do Ar em Interiores Visando a Saúde Pública no Brasil - Revista da Brasindoor . 2 (10): 4$21,1999$. 
4 Conselho Nacional do Meio Ambiente - CONAMA, Resolução n.ํ 03 de 28/06 / 1990.

5 ABNT - Associação Brasileira de Normas Técnicas, NBR 6401 - Instalações Centrais de Ar Condicionado para Conforto - Parâmetros Básicos de Projeto , 1980.

6 Siqueira, LFG \& Dantas, EHM. Organização e Métodos no Processo de Avaliação da Qualidade do Ar de Interiores - Revista da Brasindoor , 3 (1): 19-26, 1999.

7 Aquino Neto, F.R; Brickus, L.S.R. Padrões Referenciais para Análise de Resultados da Qualidade Físicoquímica do Ar de Interior Visando a Saúde Pública . Revista da Brasindoor , 3(2):4 -15,1999

NORMA TÉCNICA 001

Qualidade do Ar Ambiental Interior. Método de Amostragem e Análise de Bioaerosol em Ambientes Interiores.

\section{MÉTODO ANALÍTICO}

OBJETIVO: Pesquisa, monitoramento e controle ambiental da possível colonização, multiplicação e disseminação de fungos em ar ambiental interior.

\section{DEFINIÇÕES:}

Bioaerosol: Suspensão de microorganismos (organismos viáveis) dispersos no ar.

Marcador epidemiológico : Elemento aplicável à pesquisa, que determina a qualidade do ar ambiental.

APLICABILIDADE: Ambientes de interior climatizados, de uso coletivo, destinados a ocupações comuns (não especiais).

MARCADOR EPIDEMIOLÓGICO: Fungos viáveis.

MÉTODO DE AMOSTRAGEM: Amostrador de ar por impactação com acelerador linear.

PERIODICIDADE: Semestral.

FICHA TÉCNICA DO AMOSTRADOR:

Amostrador: Impactador de 1, 2 ou 6 estágios.

Meio de Cultivo: Agar Extrato de Malte, Agar Sabouraud Dextrose a 4\%, Agar Batata Dextrose ou outro, desde que cientificamente validado.

Taxa de Vazão: fixa entre 25 a 35 l/min, sendo recomendada 28,3 l/min.

Tempo de Amostragem: de 5 a 15 minutos, dependendo das especificações do amostrador.

Volume Mínimo: 140 I

Volume Máximo: 500 I

Embalagem: Rotina de embalagem para proteção da amostra com nível de biossegurança 2 (recipiente lacrado, devidamente identificado com símbolo de risco biológico)

Transporte: Rotina de embalagem para proteção da amostra com nível de biossegurança 2 (recipiente lacrado, devidamente identificado com símbolo de risco biológico)

Nota: Em áreas altamente contaminadas, pode ser recomendável uma amostragem com tempo e volume menores.

\begin{tabular}{|l|l|}
\hline Calibração: Semestral & Exatidão: 0,02 l/min. \\
& Precisão: $99,92 \%$ \\
\hline
\end{tabular}

ESTRATÉGIA DE AMOSTRAGEM:

selecionar 01 amostra de ar exterior localizada fora da estrutura predial na altura de 1,50 m do nível da rua. 
Definir o número de amostras de ar interior, tomando por base a área construída climatizada dentro de uma mesma edificação e razão social, seguindo a tabela abaixo:

\begin{tabular}{|c|c|}
\hline Área construída (m 2) & Número mínimo de amostras \\
\hline Até 1.000 & 3 \\
\hline 1.000 a 2.000 & 5 \\
\hline 2.000 a 3.000 & 8 \\
\hline 3.000 a 5.000 & 12 \\
\hline 5.000 a 10.000 & 15 \\
\hline 10.000 a 15.000 & 18 \\
\hline 15.000 a 20.000 & 21 \\
\hline 20.000 a 30.000 & 25 \\
\hline Acima de 30.000 & 15 \\
\hline
\end{tabular}

As unidades funcionais dos estabelecimentos com características epidemiológicas diferenciadas, tais como serviço médico, restaurantes, creches e outros, deverão ser amostrados isoladamente. os pontos amostrais deverão ser distribuídos uniformemente e coletados com o amostrador localizado na altura de 1,5 m do piso, no centro do ambiente ou em zona ocupada.

PROCEDIMENTO LABORATORIAL: Método de cultivo e quantificação segundo normatizações universalizadas. Tempo mínimo de incubação de 7 dias a 250C., permitindo o total crescimento dos fungos.

BIBLIOGRAFIA: "Standard Methods for Examination of Water and Wastewater".17 th ed. APHA, AWWA, WPC.F; "The United States Pharmacopeia". USP, XXIII ed., NF XVIII, 1985.

NIOSH- National Institute for Occupational Safety and Health, NIOSH Manual of Analytical Methods (NMAM),

BIOAEROSOL SAMPLING (Indoor Air) 0800, Fourth Edition.

IRSST - Institute de Recherche en Santé et en Securité du Travail du Quebec, Canada, 1994.

Members of the Technicael Advisory Committee on Indoor Air Quality, Commission of Public Health Ministry of the

Environment - Guidelines for Good Indoor Air Quality in Office Premises, Singapore.

NORMA TÉCNICA 002

Qualidade do Ar Ambiental Interior. Método de Amostragem e Análise da Concentração de Dióxido de Carbono em Ambientes Interiores.

\section{MÉTODO ANALÍTICO}

OBJETIVO: Pesquisa, monitoramento e controle do processo de renovação de ar em ambientes climatizados.

APLICABILIDADE: Ambientes interiores climatizados, de uso coletivo.

MARCADOR EPIDEMIOLÓGICO: Dióxido de carbono ( CO2 ).

MÉTODO DE AMOSTRAGEM: Equipamento de leitura direta.

PERIODICIDADE: Semestral.

FICHA TÉCNICA DOS AMOSTRADORES:

Amostrador: Leitura Direta por meio de sensor infravermelho não dispersivo ou célula eletroquímica. 
Calibração: Anual ou de acordo com especificação do Faixa: de 0 a 5.000 ppm. fabricante.

Exatidão: $50 \mathrm{ppm}+2 \%$ do valor medido

\section{ESTRATÉGIA DE AMOSTRAGEM:}

Definir o número de amostras de ar interior, tomando por base a área construída climatizada dentro de uma mesma edificação e razão social, seguindo a tabela abaixo:

\begin{tabular}{|c|c|}
\hline Área construída (m 2 ) & Número mínimo de amostras \\
\hline Até 1.000 & 3 \\
\hline 1.000 a 2.000 & 5 \\
\hline 2.000 a 3.000 & 8 \\
\hline 3.000 a 5.000 & 12 \\
\hline 5.000 a 10.000 & 15 \\
\hline 10.000 a 15.000 & 18 \\
\hline 15.000 a 20.000 & 21 \\
\hline 20.000 a 30.000 & 25 \\
\hline Acima de 30.000 & \\
\hline
\end{tabular}

Das unidades funcionais dos estabelecimentos com características epidemiológicas diferenciadas, tais como serviço médico, restaurantes, creches e outros, deverão ser amostrados isoladamente.

Dos pontos amostrais deverão ser distribuídos uniformemente e coletados com o amostrador localizado na altura de $1,5 \mathrm{~m}$ do piso, no centro do ambiente ou em zona ocupada.

PROCEDIMENTO DE AMOSTRAGEM: As medidas deverão ser realizadas em horários de pico de utilização do ambiente.

\section{NORMA TÉCNICA 003}

Qualidade do Ar Ambiental Interior. Método de Amostragem. Determinação da Temperatura, Umidade e Velocidade do Ar em Ambientes Interiores.

\section{MÉTODO ANALÍTICO}

OBJETIVO: Pesquisa, monitoramento e controle do processo de climatização de ar em ambientes climatizados.

APLICABILIDADE: Ambientes interiores climatizados, de uso coletivo.

MARCADORES: Temperatura do ar ( ?C )

Umidade do ar (\%)

Velocidade do ar ( $\mathrm{m} / \mathrm{s})$.

MÉTODO DE AMOSTRAGEM: Equipamentos de leitura direta. Termo-higrômetro e Anemômetro.

PERIODICIDADE: Semestral.

\section{FICHA TÉCNICA DOS AMOSTRADORES:}

Amostrador: Leitura Direta - Termo-higrômetro.

Princípio de operação: Sensor de temperatura do tipo termo-resistência.

Sensor de umidade do tipo capacitivo ou por condutividade elétrica. 


\begin{tabular}{|l|l|}
\hline Calibração: Anual & $\begin{array}{l}\text { Faixa: } 0 \circ \mathrm{C} \text { a } 70 \circ \mathrm{C} \text { de temperatura e 5\% a } 95 \% \text { de } \\
\text { umidade } \\
\text { Exatidão: 0,8 } 0 \mathrm{C} \text { de temperatura ??5\% do valor } \\
\text { medido de umidade }\end{array}$ \\
\hline
\end{tabular}

Amostrador: Leitura Direta - Anemômetro.

Princípio de operação: Preferencialmente de sensor de velocidade do ar do tipo fio aquecido ou fio térmico.

Calibração: Anual

Faixa: de 0 a $10 \mathrm{~m} / \mathrm{s}$

Exatidão: ??0,1 $\mathrm{m} / \mathrm{s}$ ??4\% do valor medido

\section{ESTRATÉGIA DE AMOSTRAGEM:}

Definir o número de amostras de ar interior, tomando por base a área construída climatizada dentro de uma mesma edificação e razão social, seguindo a tabela abaixo:

\begin{tabular}{|c|c|}
\hline Área construída (m 2) & Número mínimo de amostras \\
\hline Até 1.000 & 3 \\
\hline 1.000 a 2.000 & 5 \\
\hline 2.000 a 3.000 & 8 \\
\hline 3.000 a 5.000 & 12 \\
\hline 5.000 a 10.000 & 15 \\
\hline 10.000 a 15.000 & 18 \\
\hline 15.000 a 20.000 & 21 \\
\hline 20.000 a 30.000 & 25 \\
\hline Acima de 30.000 & \\
\hline
\end{tabular}

Das unidades funcionais dos estabelecimentos com características epidemiológicas diferenciadas, tais como serviço médico, restaurantes, creches e outros, deverão ser amostrados isoladamente.

Dos pontos amostrais deverão ser distribuídos uniformemente e coletados com o amostrador localizado na altura de 1,5 $\mathrm{m}$ do piso, no centro do ambiente ou em zona ocupada, para o Termo-higrômetro e no espectro de ação do difusor para o Anemômetro.

\section{Norma Técnica 004}

Qualidade do Ar Ambiental Interior. Método de Amostragem e Análise de Concentração de Aerodispersóides em Ambientes Interiores.

MÉTODO ANALÍTICO

OBJETIVO: Pesquisa, monitoramento e controle de aerodispersóides totais em ambientes interiores climatizados.

APLICABILIDADE: Ambientes de interior climatizados, de uso coletivo, destinados a ocupações comuns (não especiais). 
MARCADOR EPIDEMIOLÓGICO: Poeira Total (mg/m3 ).

MÉTODO DE AMOSTRAGEM: Coleta de aerodispersóides por filtração (MB -3422 da ABNT).

PERIODICIDADE: Semestral.

FICHA TÉCNICA DO AMOSTRADOR:

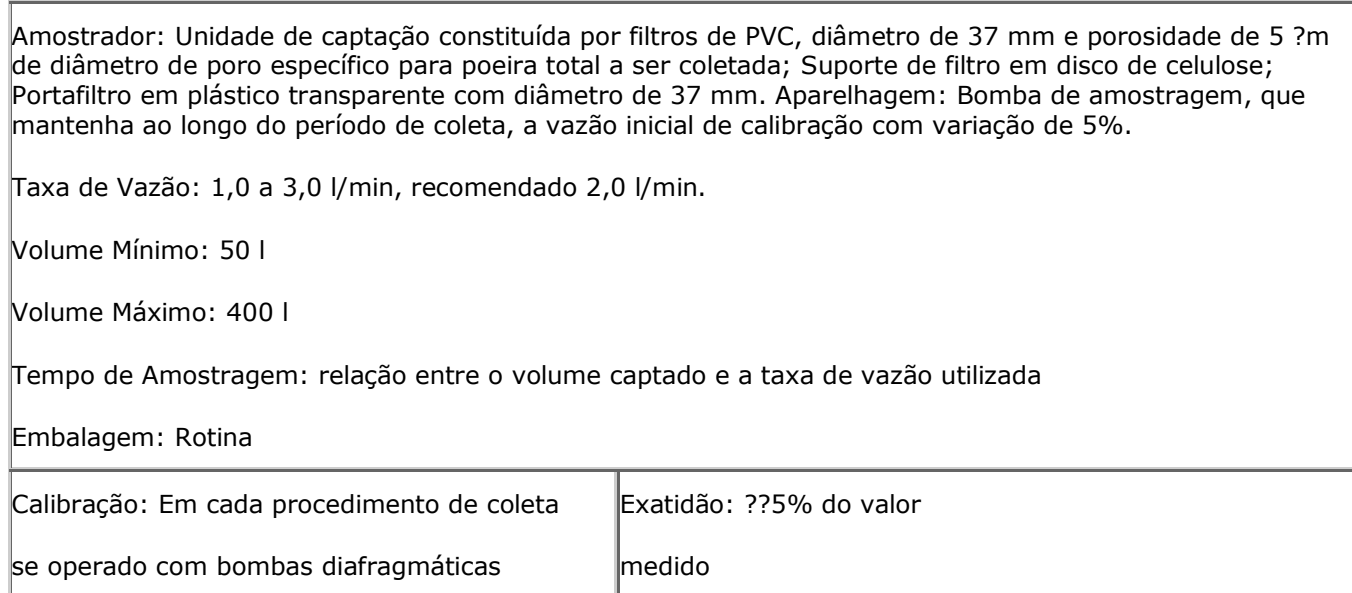

ESTRATÉGIA DE AMOSTRAGEM:

Definir o número de amostras de ar interior, tomando por base a área construída climatizada dentro de uma mesma edificação e razão social, seguindo a tabela abaixo:

\begin{tabular}{|c|c|}
\hline Área construída (m 2) & Número mínimo de amostras \\
\hline Até 1.000 & 3 \\
\hline 1.000 a 2.000 & 5 \\
\hline 2.000 a 3.000 & 8 \\
\hline 3.000 a 5.000 & 12 \\
\hline 5.000 a 10.000 & 15 \\
\hline 10.000 a 15.000 & 18 \\
\hline 15.000 a 20.000 & 21 \\
\hline 20.000 a 30.000 & 25 \\
\hline Acima de 30.000 & \\
\hline
\end{tabular}

Das unidades funcionais dos estabelecimentos com características epidemiológicas diferenciadas, tais como serviço médico, restaurantes, creches e outros, deverão ser amostrados isoladamente.

Dos pontos amostrais deverão ser distribuídos uniformemente e coletados com o amostrador localizado na altura de $1,5 \mathrm{~m}$ do piso, no centro do ambiente ou em zona ocupada.

PROCEDIMENTO DE COLETA: MB-3422 da ABNT.

PROCEDIMENTO DE CALIBRAÇÃO DAS BOMBAS: NBR- 10.562 da ABNT

PROCEDIMENTO LABORATORIAL: NHO 17 da FUNDACENTRO

VII - INSPEÇÃO 
Recomenda que os órgãos competentes de Vigilância Sanitária com o apoio de outros órgãos governamentais, organismos representativos da comunidade e dos ocupantes dos ambientes climatizados, utilizem esta Orientação Técnica como instrumento técnico referencial, na realização de inspeções e de outras ações pertinentes nos ambientes climatizados de uso público e coletivo.

\section{VIII - RESPONSABILIDADE TÉCNICA}

Recomenda que os proprietários, locatários e prepostos de estabelecimentos com ambientes ou conjunto de ambientes dotados de sistemas de climatização com capacidade igual ou superior a 5 TR $(15.000 \mathrm{kcal} / \mathrm{h}=$ $60.000 \mathrm{BTU} / \mathrm{h}$ ), devam manter um responsável técnico atendendo ao determinado na

Portaria GM/MS no 3.523/98, além de desenvolver as seguintes atribuições:

a) providenciar a avaliação biológica, química e física das condições do ar interior dos ambientes climatizados;

b) promover a correção das condições encontradas, quando necessária, para que estas atendam ao estabelecido no

Art. $4^{\circ}$ desta Resolução;

c) manter disponível o registro das avaliações e correções realizadas;

d) divulgar aos ocupantes dos ambientes climatizados os procedimentos e resultados das atividades de avaliação, correção e manutenção realizadas.

Em relação aos procedimentos de amostragem, medições e análises laboratoriais, considera-se como responsável técnico, o profissional que tem competência legal para exercer as atividades descritas, sendo profissional de nível superior com habilitação na área de química (Engenheiro químico, Químico e Farmacêutico) e na área de biologia (Biólogo, Farmacêutico e Biomédico) em conformidade com a regulamentação profissional vigente no país e comprovação de Responsabilidade Técnica - RT, expedida pelo Órgão de Classe.

As análises laboratoriais e sua responsabilidade técnica devem obrigatoriamente estar desvinculadas das atividades de limpeza, manutenção e comercialização de produtos destinados ao sistema de climatização. 
ANEXO B - Portaria no 3.523

\section{8 e Agosto de 1998}

- Ministro do Estado da Saúde, no uso das atribuições que lhe confere o artigo 87, Parágrafo único, item II da Constituição Federal e tendo em vista o disposto nos artigos 60, I, "a", "c", V, VII, IX, S10, I a VI, da Lei n 8080 , de 19 de setembro de 1990.

Considerando a preocupação mundial com a Qualidade do ar de Interiores em ambientes climatizados e a ampla e crescente utilização de sistemas de ar condicionado no país, em função das condições climáticas;

Considerando a preocupação com a saúde, o bem estar, o conforto, a produtividade e o absenteísmo ao trabalho, dos ocupantes dos ambientes climatizados e a sua inter-relação com a variável qualidade de vida;

Considerando a qualidade do ar de interiores em ambientes climatizados e sua correlação com a Síndrome dos Edifícios Doentes relativa a ocorrência de agravos de saúde;

Considerando que o projeto e a execução da instalação, inadequados, a operação e a manutenção precárias dos sistemas de climatização, favorecem a ocorrência e o agravamento de problema de saúde.

Considerando a necessidade de serem aprovados procedimentos que visem minimizar o risco potencial à saúde dos ocupantes, em face da permanência prolongada em ambientes climatizados, resolve :

Art. $1^{\circ}$ Aprovar Regulamento Técnico contendo medidas básicas para a melhoria da Qualidade do $\mathrm{Ar}$ de Interior e prevenção de riscos à saúde dos ocupantes de ambientes climatizados.

Art. $2^{\circ}$ Determinar que as medidas específicas referentes às exigências de padrões de qualidade de ar em ambientes climatizados, seus métodos de controle, pré-requisitos de projetos de instalação e de execução de sistemas de climatização e outras, serão objeto de Regulamento Técnico a ser elaborado por este Ministério.

Art. $3^{\circ}$ As medidas aprovadas por este Regulamento Técnico aplicam-se aos ambientes climatizados de uso coletivo já existentes e aqueles a serem executados e de forma complementar, aos regidos por normas e regulamentos específicos.

Parágrafo Único. Para os ambientes climatizados com exigências de filtros absolutos ou instalações especiais, tais como aquelas que atendem a processos produtivos, instalações hospitalares e outros, aplicam-se as normas e regulamentos específicos, sem prejuízo do disposto neste Regulamento Técnico, no que couber.

Art. $4^{\circ}$ Adotar para fins deste Regulamento Técnico as seguintes definições:

- ambientes climatizados: ambientes submetidos ao processo de climatização.

- ar de renovação: ar externo que é introduzido no ambiente climatizado.

- ar de retorno: ar que recircula no ambiente climatizado.

- Boa qualidade de ar interno: conjunto de propriedades física, químicas e biológicas do ar que não apresentem agravos à saúde humana;

- climatização: conjunto de processos empregados para se obter por meio de equipamentos em recintos fechados, condições específicas de conforto e boa qualidade do ar, adequadas ao bem estar dos ocupantes.

- filtro absoluto: filtro de classe A1 até A3, conforme especificações do Anexo II.

- limpeza: procedimento de manutenção preventiva que consiste na remoção de sujidades dos componentes do sistema de climatização, para evitar sua dispersão no ambiente interno.

- manutenção - atividades técnicas e administrativas destinadas a preservar as características de desempenho técnico dos componentes ou sistemas de climatização, garantindo as condições previstas neste Regulamento Técnico.

- Síndrome dos Edifícios Doentes: consiste no surgimento de sintomas que são comuns `população em geral, mas que, numa situação temporal, pode ser relacionado a um edifício em particular. Um incremento substancial na prevalência dos níveis dos sintomas, relacionados, proporciona a relação entre o edifício e seus ocupantes. 
Art. $5^{\circ}$ Todos os sistemas de climatização devem estar em condições adequadas de limpeza, manutenção, operação e controle, observadas as determinações, abaixo relacionadas, visando a prevenção de riscos à saúde dos ocupantes.

- manter limpos os componentes do sistema de climatização, tais como: bandejas, serpentinas, umidificadores, ventiladores e dutos de forma a evitar a difusão ou multiplicação de agentes nocivos à saúde humana e manter a boa qualidade do ar interno.

- utilizar na limpeza dos componentes do sistema de climatização, produtos biodegradáveis devidamente registrados no Ministério da Saúde para esse fim.

- verificar periodicamente as condições físicas dos filtros e mantê-los em condições de operação. Promover a sua substituição quando necessária.

- restringir a utilização do compartimento onde está instalada a caixa de mistura do ar de retorno e ar de renovação, ao uso exclusivo do sistema de climatização. Éproibido conter no mesmo compartimento materiais, produtos ou utensílios.

- preservar a captação de ar externo livre de possíveis fontes poluentes externas que apresentem riscos a saúde humana e dotá-la no mínimo de filtro classe G1 (um) conforme as especificações do Anexo II.

- garantir a adequada renovação do ar de interior dos ambientes climatizados, ou seja no mínimo de $27 \mathrm{~m}$ $3 / \mathrm{h} /$ pessoa.

- descartar as sujidades sólidas, retiradas do sistema de climatização após a limpeza, acondicionadas em sacos de material resistente e porosidade adequada, para evitar o espalhamento de partículas inaláveis.

Art. $6^{\circ}$ Os proprietários, locatários e prepostos, responsáveis por sistemas de climatização com capacidade acima de 5 TR $(1500 \mathrm{kcal} / \mathrm{h}=60.000 \mathrm{BTU} / \mathrm{H})$, deverão manter um responsável técnico habilitado, com as seguintes atribuições:

- implantar e manter disponível no imóvel em Plano de Manutenção, Operação e Controle - PMOC, adotado para o sistema de climatização. Este plano deve conter a identificação do estabelecimento que possui ambientes climatizados, a descrição das atividades a serem desenvolvidas, a periodicidade das mesmas, as recomendações a serem adotadas em situações de falha do equipamento e de emergência, para garantia de segurança do sistema de climatização e outras de interesse, conforme especificações contidas no Anexo I deste Regulamento Técnico e NBR 13971/97 da ABNT.

- garantir a aplicação do PMOC por intermédio da execução continua direta ou indireta deste serviço.

- manter disponível o registro da execução dos procedimentos estabelecidos no PMOC.

- divulgar os procedimentos e resultados das atividades de manutenção, operação e controle aos ocupantes. Parágrafo Único. O PMOC deverá ser implantado no prazo máximo de 180 dias, a partir da vigência deste Regulamento Técnico.

Art. 70 O PMOC do sistema de climatização deve estar coerente com a legislação de Segurança e Medicina do Trabalho. Os procedimentos de manutenção, operação e controle dos sistemas de climatização e limpeza dos ambientes climatizados, não devem trazer riscos a saúde dos trabalhadores que os executam, nem aos ocupantes dos ambientes climatizados.

Art. $8^{\circ}$ Os Órgãos competentes de Vigilância Sanitária farão cumprir este Regulamento Técnico, mediante a realização de inspeções e de outras ações pertinentes, com o apoio de órgãos governamentais, organismos representativos da comunidade e ocupantes dos ambientes climatizados.

Art. $9 \circ 0$ não cumprimento deste Regulamento Técnico configura infração sanitária, sujeitando o proprietário ou locatário do imóvel ou preposto, bem como o responsável técnico, quando exigido, às penalidades previstas na Lei no 6.437 de 20 de agosto de 1977, sem prejuízo de outras penalidades previstas em legislação específica.

Art. $10^{\circ}$ Este Regulamento Técnico entra em vigor na data da sua publicação, revogadas as disposições em contrário. 
ANEXO C - Equipamentos

Os principais componentes do equipamento Dust Trak Aerosol Monitor utilizado nesta pesquisa são apresentados a seguir:

- 1 Monitor para aerodispersóides.

- 1 Gabinete para uso ao ar livre.

- 2 Baterias de Chumbo.

- 1 Carregador.

- 1 Entrada para amostragem.

- 1 Garrafa poly para reter água e mangueiras.

- 1 Filtro para zerar.

- 1 Kit de ferramentas para manutenção variada.

- 1 Cabo para comunicação entre o computador e o equipamento.

- 1 Adaptador e Fonte AC (130-115V).

- 1 Medidor de vazão de ar (0-2,5 L/min).

Na Figura 1, identificam-se as principais partes funcionais do monitor, anteriormente mencionado.
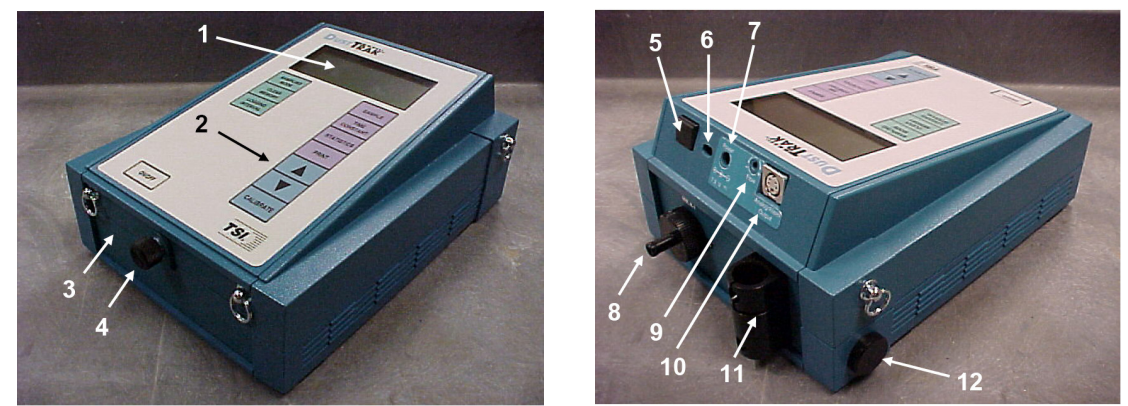

Figura 1 - Vista frontal e vista posterior do equipamento Dust Trak Aerosol Monitor (modelo 8520).

$\begin{array}{llll}1 & \text { Display digital } & 7 & \text { Fonte externa de energia } \\ 2 & \text { Teclado } & 8 & \text { Entrada da amostra } \\ 3 & \text { Tampa das pilhas } & 9 & \text { Controle de vazão de ar } \\ 4 & \text { Botão para abrir a tampa } & 10 & \text { Porta para impressora } \\ & \text { das pilhas } & 11 & \text { Suporte para o ciclone }\end{array}$


As medições possuem alguns procedimentos experimentais de rotina, a fim de manter o adequado funcionamento do equipamento, inclusive evitando erros nos valores obtidos. Estes procedimentos são realizados antes e após cada medição para todos os ambientes. Portanto, o monitor foi submetido aos seguintes procedimentos:

- Com o display em funcionamento, o equipamento foi calibrado, colocando o filtro de zerar na entrada da amostra (8). Se a concentração em massa de aerodispersóide não zerasse, pressionou-se a tecla calibrate por cinco segundos, depois a tecla sample por 60 segundos, e por fim as teclas calibrate e sample.

- Após a realização da calibragem, o procedimento foi programar o monitor para ligar e desligar entre as medições. Utilizando-se, para tanto, o cabo de comunicação com o computador, colocado entre a porta de entrada e saída de cada equipamento (5). Com o computador e o monitor ligados, fizeram-se as seguintes programações para cada medição: (a) minutos, horas e dias para o início, (b) período do ensaio em minutos, horas e dias, (c) intervalo de leitura da amostra em horas e minutos.

- Após a programação, fez-se a colocação do equipamento no centro do ambiente a ser medido.

$\mathrm{Na}$ seqüência, são mostradas as fotos do equipamento na sala de computação da Escola Politécnica da Universidade de São Paulo (EPUSP), medindo a concentração em massa de aerodispersóides, sobre uma mesa no centro do ambiente, durante uma aula. 

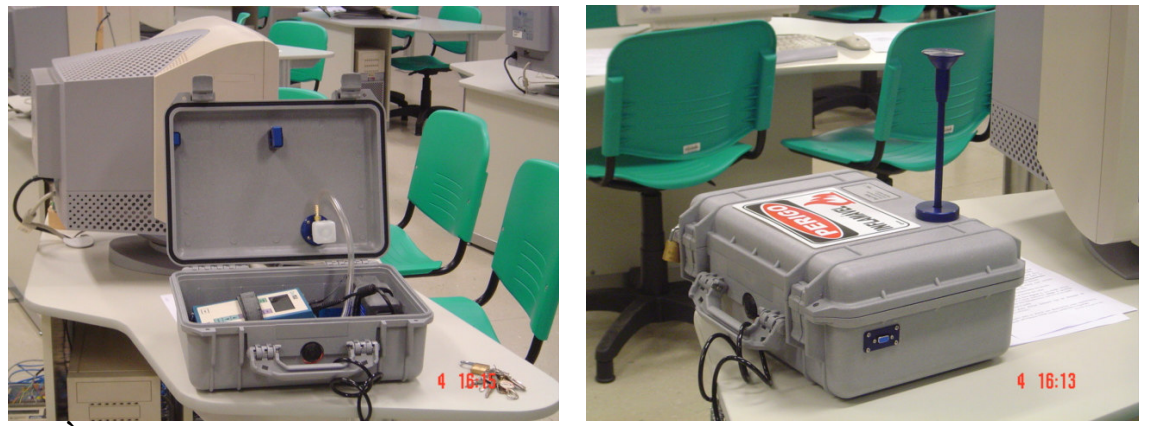

Figura 2 - A esquerda, vista do gabinete aberto com o monitor de aerodispersóides e à direita, vista do gabinete fechado, com a haste de entrada do amostrador.

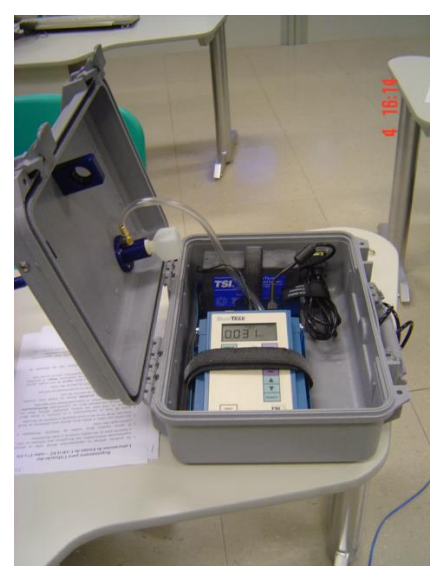

Figura 3 - Detalhe do monitor e da bateria de chumbo posicionada na parte superior do gabinete.

Os principais componentes do equipamento P-Trak Ultrafine Particle Counter utilizado nesta pesquisa são apresentados a seguir:

- 1 Contador de aerodispersóides.

- 1 Haste telescópica, adaptador e mangueira de PVC.

- 1 Frasco para abastecer a cápsula com álcool e tampa de estocagem.

- 1 Cápsula para o álcool.

- 16 Frascos com álcool isopropílico $(30 \mathrm{ml})$.

- 2 Filtros para zerar.

- 1 Cabo para comunicação entre o computador e o equipamento.

- 1 Adaptador e Fonte AC (115V). 
$\mathrm{Na}$ Figura 4, identificam-se as principais partes funcionais do contador utilizado nesta pesquisa.

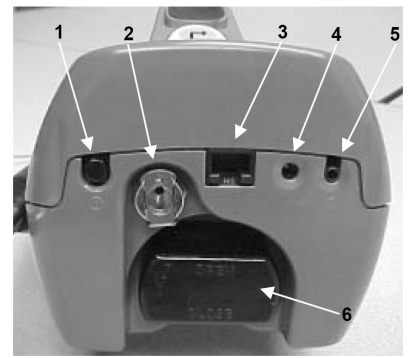

Figura 4 - Vista posterior do equipamento P-Trak Ultrafine Particle Counter (modelo 8525).

$\begin{array}{llll}1 & \text { Botão liga/desliga } & 4 & \text { Fonte externa de energia } \\ 2 & \text { Entrada da amostra } & 5 & \text { Porta do fone de ouvido } \\ 3 & \text { Porta de entrada e saída de dados } & 6 & \text { Cápsula para o álcool }\end{array}$

As medições tiveram os procedimentos experimentais de rotina mostrados a seguir, com intuito de manter um padrão de funcionamento nos ensaios, inclusive evitando erros na obtenção dos valores. Estes procedimentos são realizados antes e depois de cada medição para todos os ambientes analisados. Portanto, o contador de aerodispersóides foi submetido aos seguintes procedimentos:

- Com o display ligado, o equipamento foi calibrado, colocando o filtro de zerar na entrada da amostra (2). Se a concentração em número de aerodispersóides não zerasse, aguardaram-se alguns minutos com o equipamento funcionando até estabilizar a concentração e mostrar no display o valor zero.

- Após a realização da calibragem, o contador foi programado para ligar e desligar entre as medições. Utilizando-se, para tanto, os mesmos procedimentos do monitor de aerodispersóide, igualmente mostrados.

- Após a programação, fez-se a colocação do equipamento no centro do ambiente a ser medido. 
Nas Figuras 5 e 6, apresenta-se uma medição realizada na sala de computação da EPUSP, utilizando o contador de aerodispersóides, sobre uma mesa no centro do ambiente.

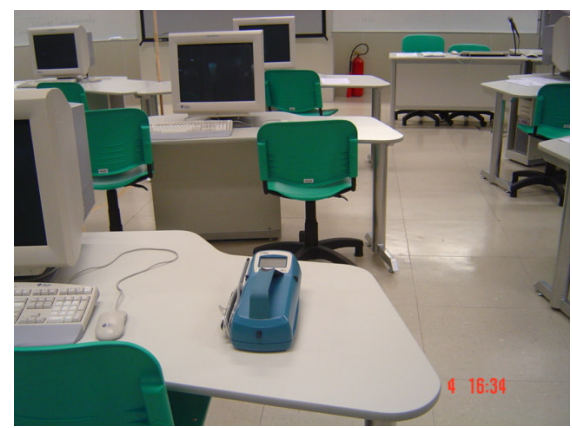

Figura 5 - Vista do contador de aerodispersóides na sala de computação-CAD, EPUSP.

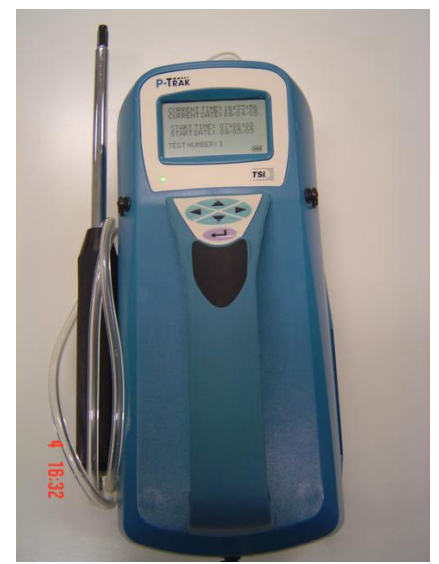

Figura 6 - Detalhe do contador de aerodispersóides em uso com a haste e a mangueira de PVC posicionada ao seu lado.

A validação dos métodos de medição, segundo a NBR 13.412/1995, deve atender aos seguintes requisitos:

- A velocidade facial na entrada do equipamento deve ser uniforme.

- O equipamento deve ser instalado em posição horizontal e com fluxo de ar em sentido descendente.

- O equipamento deve ser protegido contra precipitação, insetos e outros materiais que possam interferir na amostragem. 
- O vazamento de ar que possa causar erros na medida do volume de ar que passa pelo equipamento deve ser eliminado.

- A saída de ar de exaustão deve estar a uma distância suficiente da entrada de amostragem, de forma a minimizar a coleta de ar da exaustão.

- A captação de poeira oriunda da superfície do piso onde o amostrador está instalado deve ser minimizada.

- A calibragem do amostrador antes de usar os equipamentos, seguindo o manual do fabricante.

- Deve ser efetuada periodicamente a limpeza completa nas peças do equipamento, de acordo com as recomendações do fabricante. Esta limpeza visa evitar erros na amostragem provocada por arraste de partículas retidas no equipamento.

- Quando o equipamento não estiver operando, deve-se proteger a abertura de entrada de ar, de modo a evitar a entrada de insetos ou outros elementos estranhos à amostragem.

Para o Dust Trak Aerosol Monitor, os valores médios, mínimos e máximos de concentração em massa, para estabilidade zero do equipamento, foram respectivamente de $0,000 \mu \mathrm{g} / \mathrm{m}^{3}, 0,000 \mu \mathrm{g} / \mathrm{m}^{3}$ e $0,001 \mu \mathrm{g} / \mathrm{m}^{3}$. Isto quer dizer que a máxima variação esperada será de uma a cada mil partes medidas. A NBR 13.412/1995 determina, para este modelo, que a concentração máxima esperada, calculada para um amostrador de aerodispersóides, com diâmetro aerodinâmico maior ou igual a $10 \mu \mathrm{m}$, em amostragem de uma distribuição específica de tamanhos de partículas, deve estar dentro de $10 \%$ da concentração calculada para um amostrador ideal.

Para o P-Trak Ultrafine Particle Counter, o limite de tolerância da calibragem, entre o teste padrão e o teste do equipamento, pode variar entre 95 e 105\%, não tendo valores maiores ou menores desta faixa, segundo certificado do fabricante. A NBR 13.700/1996 determina, para este modelo, uma eficiência de contagem de 50\% em $0,02 \mu \mathrm{m}$ e inclui uma faixa de tolerância de $\pm 0,002 \mu \mathrm{m}$. As eficiências de contagem mínima e máxima aceitável fora da faixa de tolerância de $0,018 \mu \mathrm{m}$ a $0,022 \mu \mathrm{m}$ são 
baseadas na penetração calculada de um elemento de difusão, tendo $40 \%$ de eficiência a $0,02 \mu \mathrm{m}$ (partículas com diâmetro maior que $0,022 \mu \mathrm{m}$ ) ou $60 \%$ de eficiência a $0,02 \mu \mathrm{m}$ (partículas com diâmetro menor do que $0,018 \mu \mathrm{m}$ ). 